\title{
Patient education for adults with rheumatoid arthritis (Review)
}

\author{
Riemsma RP, Kirwan JR, Taal E, Rasker HJJ
}

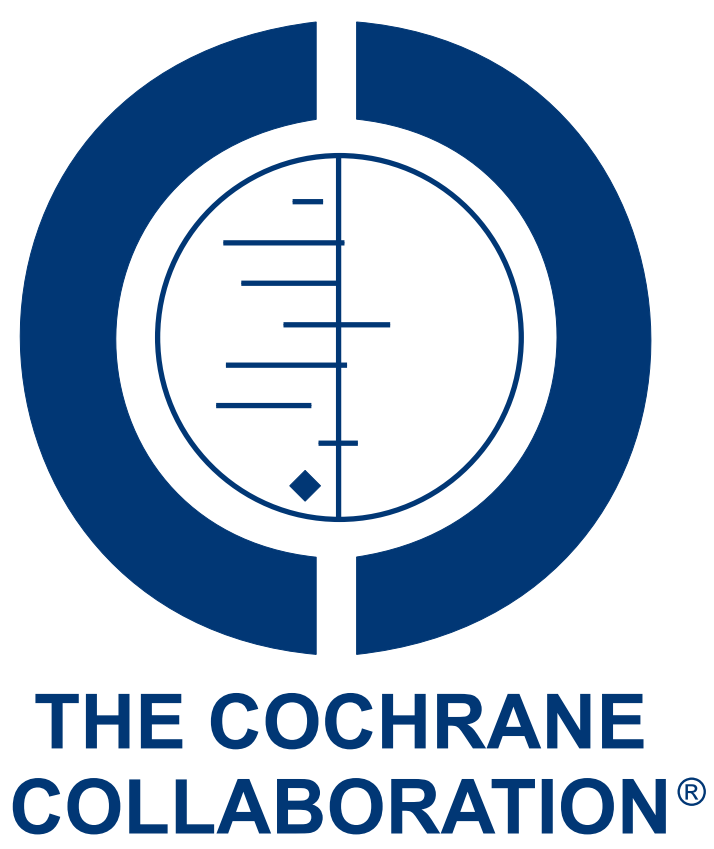

This is a reprint of a Cochrane review, prepared and maintained by The Cochrane Collaboration and published in The Cochrane Library 2009, Issue 1

http://www.thecochranelibrary.com

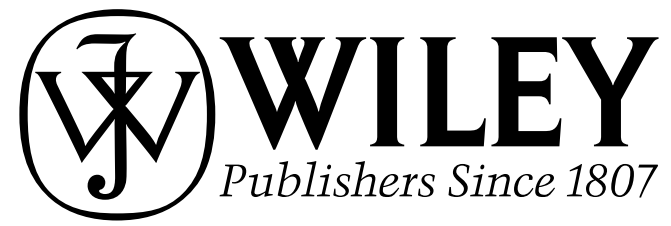

Patient education for adults with rheumatoid arthritis (Review)

Copyright $\odot 2009$ The Cochrane Collaboration. Published by John Wiley \& Sons, Ltd. 
TABLE OF CONTENTS

HEADER . . . . . . . . . . . . . . . . . . . . . . . . . . . . . . . . 1

ABSTRACT .. . . . . . . . . . . . . . . . . . . . . . . . . . . . . . . . . . . . . . . . . . . . . . . . .

PLAIN LANGUAGE SUMMARY . . . . . . . . . . . . . . . . . . . . . . . . . . . . . . . . . . . . . .

BACKGROUND . . . . . . . . . . . . . . . . . . . . . . . . . . . . . . . . . . . . . 2

OBJECTIVES . . . . . . . . . . . . . . . . . . . . . . . . . . . . . . . . . . . . . . .

METHODS . . . . . . . . . . . . . . . . . . . . . . . . . . . . . . . . . . . . . . 2

RESULTS . . . . . . . . . . . . . . . . . . . . . . . . . . . . . . . . . . . . . . . . . 44

DISCUSSION . . . . . . . . . . . . . . . . . . . . . . . . . . . . . . . . . . . . . . . . . . . .

AUTHORS' CONCLUSIONS . . . . . . . . . . . . . . . . . . . . . . . . . . . . . . . . . . . . . . . 19

ACKNOWLEDGEMENTS . . . . . . . . . . . . . . . . . . . . . . . . . . . . . . . . . . . . . . . . . . 19

REFERENCES . . . . . . . . . . . . . . . . . . . . . . . . . . . . . . . . . . . . . 19

CHARACTERISTICS OF STUDIES . . . . . . . . . . . . . . . . . . . . . . . . . . . . . . . . . . . . . . . $\quad . \quad 25$

DATA AND ANALYSES . . . . . . . . . . . . . . . . . . . . . . . . . . . . . . . . . . 62

Analysis 1.1. Comparison 1 Patient Education versus Controls, Outcome 1 Pain. . . . . . . . . . . . . . . . . 65

Analysis 1.2. Comparison 1 Patient Education versus Controls, Outcome 2 Disability. . . . . . . . . . . . . . . . 67

Analysis 1.3. Comparison 1 Patient Education versus Controls, Outcome 3 Joint Counts. . . . . . . . . . . . . 70

Analysis 1.4. Comparison 1 Patient Education versus Controls, Outcome 4 Patient Global Assessment. . . . . . $\quad$. 72

Analysis 1.6. Comparison 1 Patient Education versus Controls, Outcome 6 Psychological Status. . . . . . . . . $\quad 73$

Analysis 1.7. Comparison 1 Patient Education versus Controls, Outcome 7 Anxiety. . . . . . . . . . . . . . . . 75

Analysis 1.8. Comparison 1 Patient Education versus Controls, Outcome 8 Depression. . . . . . . . . . . . . . 77

Analysis 1.9. Comparison 1 Patient Education versus Controls, Outcome 9 Disease Activity. . . . . . . . . . . . 79

Analysis 2.1. Comparison 2 Information Only versus Controls, Outcome 1 Pain. . . . . . . . . . . . . . . . . 80

Analysis 2.2. Comparison 2 Information Only versus Controls, Outcome 2 Disability. . . . . . . . . . . . . . . . 81

Analysis 2.3. Comparison 2 Information Only versus Controls, Outcome 3 Joint Counts. . . . . . . . . . . . . $\quad 82$

Analysis 2.4. Comparison 2 Information Only versus Controls, Outcome 4 Patient Global Assessment. ... . .83

Analysis 2.6. Comparison 2 Information Only versus Controls, Outcome 6 Psychological Status. . . . . . . . . . $\quad 84$

Analysis 2.7. Comparison 2 Information Only versus Controls, Outcome 7 Anxiety. . . . . . . . . . . . . . . . 85

Analysis 2.8. Comparison 2 Information Only versus Controls, Outcome 8 Depression. . . . . . . . . . . . . 86

Analysis 2.9. Comparison 2 Information Only versus Controls, Outcome 9 Disease Activity. . . . . . . . . . . . . $\quad$. 87

Analysis 3.1. Comparison 3 Counselling versus Controls, Outcome 1 Pain. . . . . . . . . . . . . . . . . . . . . 88

Analysis 3.2. Comparison 3 Counselling versus Controls, Outcome 2 Disability. . . . . . . . . . . . . . . . . . 89

Analysis 3.3. Comparison 3 Counselling versus Controls, Outcome 3 Joint Counts. . . . . . . . . . . . . . . . . 90

Analysis 3.4. Comparison 3 Counselling versus Controls, Outcome 4 Patient Global Assessment. . . . . . . . . . 90

Analysis 3.6. Comparison 3 Counselling versus Controls, Outcome 6 Psychological Status. . . . . . . . . . . . . . . 91

Analysis 3.7. Comparison 3 Counselling versus Controls, Outcome 7 Anxiety. . . . . . . . . . . . . . . . . . . 92

Analysis 3.8. Comparison 3 Counselling versus Controls, Outcome 8 Depression. . . . . . . . . . . . . . . . . 93

Analysis 3.9. Comparison 3 Counselling versus Controls, Outcome 9 Disease Activity. . . . . . . . . . . . . . . . . 94

Analysis 4.1. Comparison 4 Behavioural Treatment versus Controls, Outcome 1 Pain. . . . . . . . . . . . . . . . 94

Analysis 4.2. Comparison 4 Behavioural Treatment versus Controls, Outcome 2 Disability. . . . . . . . . . . . . 96

Analysis 4.3. Comparison 4 Behavioural Treatment versus Controls, Outcome 3 Joint Counts. . . . . . . . . . . . . 98

Analysis 4.4. Comparison 4 Behavioural Treatment versus Controls, Outcome 4 Patient Global Assessment. . . . $\quad 100$

Analysis 4.6. Comparison 4 Behavioural Treatment versus Controls, Outcome 6 Psychological Status. . . . . . . . 101

Analysis 4.7. Comparison 4 Behavioural Treatment versus Controls, Outcome 7 Anxiety. . . . . . . . . . . . . 102

Analysis 4.8. Comparison 4 Behavioural Treatment versus Controls, Outcome 8 Depression. . . . . . . . . . . 104

Analysis 4.9. Comparison 4 Behavioural Treatment versus Controls, Outcome 9 Disease Activity. . . . . . . . . . 106

APPENDICES . . . . . . . . . . . . . . . . . . . . . . . . . . . . . . . . . . . . . 106

WHAT'S NEW . . . . . . . . . . . . . . . . . . . . . . . . . . . . . . . . . . . . . 107

HISTORY . . . . . . . . . . . . . . . . . . . . . . . . . . . . . . . . . . . . . . . 107

CONTRIBUTIONS OF AUTHORS . . . . . . . . . . . . . . . . . . . . . . . . . . . . . . . . . . . . . . . 107

DECLARATIONS OF INTEREST . . . . . . . . . . . . . . . . . . . . . . . . . . . . . . . . . . 108

SOURCES OF SUPPORT . . . . . . . . . . . . . . . . . . . . . . . . . . . . . . . . . . . . . . . . . . . . .

Patient education for adults with rheumatoid arthritis (Review)

Copyright (? 2009 The Cochrane Collaboration. Published by John Wiley \& Sons, Ltd. 


\title{
[Intervention Review]
}

\section{Patient education for adults with rheumatoid arthritis}

\author{
Robert P Riemsma ${ }^{1}$, John R Kirwan ${ }^{2}$, Erik Taal ${ }^{3}$, Hans, JJ Rasker ${ }^{4}$ \\ ${ }^{1}$ NHS Centre for Reviews and Dissemination, University of York, York, UK. ${ }^{2}$ Rheumatology Unit, University of Bristol, Bristol \\ Royal Infirmary, Bristol, UK. ${ }^{3}$ Department of Communication Studies, University of Twente, Enschede, Netherlands. ${ }^{4}$ Department \\ of Communication Studies (WMW), University of Twente, Enschede, Netherlands \\ Contact address: Robert P Riemsma, NHS Centre for Reviews and Dissemination, University of York, York, YO10 5DD, UK. \\ rpr1@york.ac.uk.
}

Editorial group: Cochrane Musculoskeletal Group.

Publication status and date: Edited (no change to conclusions), published in Issue 1, 2009.

Review content assessed as up-to-date: 20 February 2003.

Citation: Riemsma RP, Kirwan JR, Taal E, Rasker HJJ. Patient education for adults with rheumatoid arthritis. Cochrane Database of Systematic Reviews 2003, Issue 2. Art. No.: CD003688. DOI: 10.1002/14651858.CD003688.

Copyright (C) 2009 The Cochrane Collaboration. Published by John Wiley \& Sons, Ltd.

\begin{abstract}
A B S T R A C T
Background

Because of the unpredictability people with arthritis face on a daily basis, patient education programmes have become an effective complement to traditional medical treatment giving people with arthritis the strategies and the tools necessary to make daily decisions to cope with the disease.
\end{abstract}

\section{Objectives}

To assess the effectiveness of patient education interventions on health status in patients with rheumatoid arthritis.

Search strategy

We searched MEDLINE, EMBASE and PsycINFO and the Cochrane Controlled Trials Register. A selection of review articles (see references) were examined to identify further relevant publications. There was no language restriction.

\section{Selection criteria}

Randomised controlled trials (RCT's) evaluating patient education interventions that included an instructional component and a nonintervention control group; pre- and post-test results available separately for RA, either in the publication or from the studies' authors; and study results presented in full, end-of-study report.

\section{Data collection and analysis}

Two reviewers examined and screened search results. Dichotomous items were summarized as relative risk. Standardized mean difference and weighted mean difference were calculated for continuous data. Heterogeneity was assessed using chi square.

\section{Main results}

Thirty-one studies with relevant data were included.

We found significant effects of patient education at first follow-up for scores on disability, joint counts, patient global assessment, psychological status, and depression. A trend favouring patient education was found for scores on pain. Physician global assessment was not assessed in any of the included studies. The dimensions of anxiety and disease activity showed no significant effects. At final follow up no significant effects of patient education were found, although there was a trend favouring patient education for scores on disability. 


\begin{abstract}
Authors' conclusions
Patient education as provided in the studies reviewed here had small short-term effects on disability, joint counts, patient global assessment, psychological status and depression. There was no evidence of long-term benefits in adults with rheumatoid arthritis.
\end{abstract}

\title{
PLAIN LANGUAGE SUMMARY
}

\section{Patient education shows short-term benefits for adults with rheumatoid arthritis.}

The purpose was to examine the effectiveness of patient education interventions on health status (pain, functional disability, psychological well-being and disease activity) in patients with rheumatoid arthritis (RA). Patient education had a small beneficial effect at first followup for disability, joint counts, patient global assessment, psychological status, and depression. At final follow-up (3-14 months) no evidence of significant benefits was found.

\section{B A C K G R O U N D}

Rheumatoid arthritis (RA) is a common, chronic condition, which is characterised by uncertain disease progression and an unpredictable course of exacerbations and remissions. Approximately 1 to $2 \%$ of the UK population are affected by RA. Various interventions may alleviate its course, and patients come into contact with a large number and variety of health professionals. For many patients, pain, disability, deformity and reduced quality of life persist in spite of treatment. There is clearly room for new approaches to enhance current treatment effectiveness. Patient education is one such approach that is thought to be beneficial in helping patients to cope and co-operate with their disease and its complex management (Kirwan 1990; Taal 1996).

As with other chronic diseases, there is no cure for most types of arthritis, including RA. Furthermore, the disease course is often unpredictable and the symptoms that patients experience can vary from day to day or even from hour to hour. Because of the unpredictability people with arthritis face on a daily basis, patient education programmes have become an effective complement to traditional medical treatment giving people with arthritis the strategies and the tools necessary to make daily decisions to cope with the disease (Hirano 1994; Taal 1997).

Patient education has been defined to be 'any set of planned educational activities designed to improve patients health behaviours and/or health status' (Lorig 1992). Lorig has further stated 'the purpose of patient education is to maintain or improve health, or, in some cases, to slow deterioration' (Lorig 1992). The focus of arthritis patient education programmes is to teach patients to adjust their daily activities as dictated daily by disease symptoms.
In other words, in addition to teaching patients what they should do, patients are also instructed on how to approach situations and to make adjustments that are appropriate for each individual and his or her own needs.

\section{O B J E C T IVES}

To examine the effectiveness of patient education interventions on health status (pain, functional disability and psychological wellbeing) in patients with rheumatoid arthritis (RA).

\section{METHODS}

\section{Criteria for considering studies for this review}

\section{Types of studies}

This review was preceded by a peer-reviewed protocol, published in the Cochrane Library.

Randomised controlled trials (RCT's) which fulfilled the following criteria were entered in the review:

- Confirmed diagnosis of RA. Studies with mixed populations were included, but only data for RA-patients were included in the 
analyses.

- Patient education interventions that include an instructional component.

- Studies with a non-intervention control group.

- Patients had to be the unit of randomisation, cluster randomised studies were excluded.

- Pre- and post-test results available separately for RA, either in the publication or from the studies' authors.

- Study results presented in full, end-of-study report.

- All languages are included in the review.

- Studies that did not include data on any of the outcome measures are reported, but excluded from the meta-analysis. If data necessary for the calculation of weighted or standard mean differences were unavailable, either in the publication or from the studies' authors, the study was also excluded from the analysis. Studies that did include data on the relevant outcome measures, but only for specific parts of the body, e.g. pain in the hand, were also excluded.

\section{Types of participants}

Trials were included of adult participants over the age of 18 with clinical confirmation of the diagnosis of RA.

\section{Types of interventions}

We defined a patient education intervention as one that includes formal structured instruction on rheumatoid arthritis and on ways to manage arthritis symptoms. Studies that used modern psychobehavioural methods to promote changes in health behaviours were also included. As a complement to an instructional component, interventions could include exercise, biofeedback or psychosocial supports.

We excluded studies in which the intervention was only behavioural (e.g. biofeedback) without an educational component, or was only social support.

\section{Types of outcome measures}

A core set of outcome measures to be used in clinical trials in RA have been identified and agreed upon by OMERACT (Tugwell 1993). This set of outcome measures has been acknowledged as the gold standard for outcome measures in RA by the World Health Organization (WHO) and the International League for Associations for Rheumatology (ILAR) (Brooks 2001).

For RA, the preliminary core set of outcomes identified by OMERACT including validated measures of acute phase reactants, disability, joint pain/tenderness, joint swelling, pain, patient and physician global assessment were selected as outcome measures to be included in this review. Since psychological status is an important aspect of health status, we also included affect-scores (psychological status, anxiety and depression).

The Arthritis Impact Measurement Scales (AIMS) are the most common used general measure of health status in patients with arthritis (Meenan 1980). The AIMS2 (Meenan 1992) is a more comprehensive and sensitive version of the Arthritis Impact Measurement Scales. For all AIMS and AIMS2 scales, scores range from 0 (good health status) to 10 (bad health status).

However, in most studies specific instruments will be used to measure the different aspects of health status.

For pain, the most common instrument besides the AIMS2-pain scales is a visual analogue scale consisting of a $10-\mathrm{cm}$ horizontal line labeled 'no pain' on the right to 'pain as bad as it could be' on the left. Subjects are asked to place a dot on the line to describe the pain that they experienced in the past week.

Disability is most often measured using the Stanford Health Assessment Questionnaire (Fries 1980). The HAQ is self-administered, and performance is measured in activities of daily living in 8 subscales: dressing and grooming, arising, eating, walking, hygiene, reach, grip, and activities, which are averaged to create a disability index ranging from 0 (able without difficulty) to 3 (not able). The Modified-HAQ (M-HAQ) (Pincus 1989) is a shorter version of the HAQ containing 8 items, scores ranging from 1 (without any difficulty) to 4 (unable to do).

Joint counts are most often assessed by means of the Ritchie Articular Index (Ritchie 1968), this index scores joint tenderness on a 4-grade scale (0-3) combined to a maximum possible score of 78 (maximum tenderness). Other commonly used instruments are the ACR joint count for number of swollen and painful joints ( ARA 1982) and Thompson's Articular Index (Thompson 1987). The ACR joint count uses the criteria of the American Rheumatism Association (ARA, now American College of Rheumatology, ACR).

Patient global assessment can be assessed by the Arthritis Impactscale of the original AIMS, or by a simple question: 'How do you rate your own health?'. Physician global assessment can be assessed by a similar global question or visual analogue scale.

There is a wide range of instruments to assess psychological status, anxiety and depression. Amongst the most common instruments used in arthritis education research are the Hospital Anxiety and Depression Scale (HAD) (Zigmond 1983), the Center for Epidemiological Studies-Depression Scale (CES-D) (Radloff 1977), and the Zung Self-Rating Depression Scale (ZSRDS) ( Zung 1964).

Disease activity is generally measured by erythrocyte sedimentation rate (ESR), C-reactive protein (CRP) or plasma viscosity. ESR is a widely used blood measure that parallels the levels of arthritis activity, particularly inflammation. CRP is an acute phase protein molecule that plays a role in the immune system and CRP levels are associated with disease activity. The plasma viscosity describes the thickness of the blood which is affected by the acute phase proteins, so it may also be used as a screening test to show disease activity in rheumatoid arthritis.

\section{Search methods for identification of studies}


We searched the following electronic databases MEDLINE, EMBASE and PsycINFO from 1966 forward to September 2002 and the Cochrane Controlled Trials Register. The search strategy was designed to achieve high recall of publications, which in turn resulted in inevitable low precision. An advanced boolean search strategy was used in MEDLINE to identify all publications on patient education interventions held within MEDLINE. The following format was used.

(rheumatoid arthritis OR arthritis) AND

(Clinical trial* OR study OR evaluation OR program OR experiment) AND

(health promotion OR patient education OR behavior therapy OR occupational therapy OR self care OR psychological adaptation OR counseling OR exercise therapy) NOT review

The format used in the searches for EMBASE and PsycINFO are in Appendix 1.

A similar search was performed in the Cochrane Controlled Trials Register and a selection of review articles (see references) were examined to identify further relevant publications.

\section{Data collection and analysis}

All identifiable RCT's comparing patient education interventions for people with RA were assessed particularly in relation to the outcome measures of pain reduction and improvements in functional abilities. The title and abstract of each citation were examined by two reviewers (RPR and ET), and the trials retrieved which, according to at least one of the reviewers, cited randomised controlled trials. If it was unclear from the title and abstract whether allocation of the intervention had been conducted in a randomised manner or whether the intervention included an educational component or whether RA patients were involved, the full report was retrieved.

Examination and screening for suitability for inclusion in the meta-analysis followed. Both reviewers then examined the full reports. Disagreements regarding inclusion status were resolved by discussion. The details of the included reports were scrutinised by RPR and a standardised form was used for data abstraction. Only results at the end of the intervention were used for comparison of efficacy of the educational intervention, therefore statistically significant differences occurring between treatments throughout the trial but not at the end of the intervention were excluded.

To allow the reader to see any differences between the studies that were included in the meta-analysis and the studies that were removed from consideration, tables are presented for the characteristics (population, size, intervention and treatment effect) of the trials included and excluded from the report.

The analysis was performed using Review Manager 4.1.

For continuous variables we calculated a weighted mean difference or a standard mean difference, in case the units of measurement were not comparable. If absolute values were reported, we calcu- lated mean differences. The mean difference for each intervention group was weighted by the sample size of the group.

Dichotomous variables were summarised as relative risks. The summary relative risk was obtained by weighting each individual relative risk by the inverse of the variance of the estimate for each trial.

The results for each trial were tested for heterogeneity using the chi square statistic.

Effect estimates were analysed using fixed effects models, unless heterogeneity, due to differences in the outcome measures, was significant (at $\mathrm{P}<0.05$ ); in which case a random effects model was used.

Potential bias in meta-analytic research is publication bias, which occurs when trials showing no effect are selectively not published (Felson 1992). One method used to detect publication bias is to plot study sample sizes versus effect sizes; a symmetric distribution of effect sizes, clustered around the effect sizes of the largest studies, would be expected in the absence of publication bias. We investigated whether publication bias existed among these studies by plotting sample sizes versus effect sizes for the outcomes that were most often reported: pain and disability.

Other sources of bias in the meta-analysis were dealt with by several sensitivity analyses. The results are shown with and without use of quality scores to examine the effect of quality scores and we have run the analysis with only the larger studies to help determine the extent to which publication bias affected the conclusions. We also compared studies based on the end-of-study results, which was sometimes after 6 weeks and sometimes after 20 weeks, depending on the interventions, and we compared trials at a fixed time point.

\section{RE S U L T S}

\section{Description of studies}

See: Characteristics of included studies; Characteristics of excluded studies.

The search strategies identified 1423 publications, which were first examined on the basis of titles and abstracts. Eleven hundred and ninety-three were excluded based on title and abstract. For 229 references the full report was retrieved. Eighty-six publications turned out to be not RCT's, in 32 publications the patients involved were not RA-patients, in 29 publications the intervention did not include an educational component, 11 publications involved secondary analysis, 8 publications did not include a nonintervention control-group, two publications only presented preliminary results, in one the intervention was education for health professionals and two turned out to be conference abstracts (so far we have not been able to find more information about these two studies) and one publication could not be retrieved (Sebro 
1993). One publication is awaiting assessment because we need more information from the authors (Newman 2001). In 6 studies the outcome variables did not include any of the selected outcome measures, these studies will be described but they are excluded from the analyses (Darmawan 1992; Feinberg 1992; Linne 2001; Pope 1998; Van Deussen 1987; Young 1995). The remaining 50 publications are included in this analysis. Among the 50 references we found three studies with double publications, therefore 47 studies were included in the analysis.

We also searched for unpublished studies, and were able to retrieve data from three additional studies that have recently been completed. One of these has subsequently been published (Savelkoul 2001). In total 50 studies are included in this analysis.

\section{Risk of bias in included studies}

Methodological quality of the included trials was assessed independently by two assessors (RPR and JRK), using an adapted version (Arroll 1998) of the instrument developed by Jadad et al. ( Jadad 1996). This was done by evaluating the methods and results of the reports without knowledge of the authors. Disagreement among the reviewers regarding the quality of the articles was readily resolved by discussion and consensus.

Our quality-scale comprises the three criteria proposed by Jadad et al., which cover three out of four criteria outlined in the Cochrane Collaboration Handbook (Clarke 2000): selection bias, attrition bias and detection bias. We added one item concerning co-interventions in order to cover the fourth criterion: performance bias as well.

One of the most important biases that may distort treatment comparisons is that which can result from the way that comparison groups are assembled (Kunz 1998). Using an appropriate method for preventing foreknowledge of treatment assignment is crucially important in trial design. When assessing a potential participant's eligibility for a trial, those who are recruiting participants and the participants themselves should remain unaware of the next assignment in the sequence until after the decision about eligibility has been made. Then, after assignment has been revealed, they should not be able to alter the assignment or the decision about eligibility. The ideal is for the process to be impervious to any influence by the individuals making the allocation. This will be most securely achieved if an assignment schedule generated using true randomisation is administered by someone who is not responsible for recruiting subjects, such as someone based in a central trial office or pharmacy. If such central randomisation cannot be organised, then other precautions are required to prevent manipulation of random assignment by those involved in recruitment.

Performance bias refers to systematic differences in care provided to comparison groups other than the intervention of interest. To protect against unintended differences in care and placebo effects, those providing and receiving care can be "blinded" so that they do not know the group to which the recipients of care have been allocated. Some research suggests that such blinding is indeed important in protecting against bias (Karlowski 1975; Colditz 1989; Schulz 1995). Studies have shown that contamination (provision of the intervention to the control group) and co-intervention (provision of unintended additional care to either comparison group) can affect study results (CCSG 1978; Sackett 1979).

Attrition bias refers to systematic differences between groups in losses of participants from the study. It has sometimes been referred to as exclusion bias but here it is called attrition bias to prevent confusion with pre-allocation exclusion and inclusion criteria for enrolling people. Because of inadequacies in reporting how losses of participants (e.g., withdrawals, dropouts, protocol deviations) are handled, reviewers should be cautious about implicit accounts of follow-up. The approach to handling losses has great potential for biasing the results and reporting inadequacies cloud this problem.

Detection bias refers to systematic differences in outcome assessment. Trials that blind outcome assessors regarding treatment allocation should logically be less likely to be biased than trials that do not.

The scoring was as follows:

Scoring system

Selection

0 . Randomisation reported but not specified, i.e. little effort to ensure proper randomisation.

1. On site computer, random number tables.

2. Centralised or in pre-numbered/coded/identical boxes or containers.

Performance (co-interventions)

0 . Allowed but not reported

1. Allowed, reported

2. Allowed, reported, analysed or not allowed.

Attrition (Losses to follow up)

0 . Follow-up $<80 \%$ overall or not reported

1. Follow-up > or equal to $80 \%$

2. Intention-to treat (ITT), explicit and clear.

Detection bias (Blinding)

0 . Not reported.

1. Reported but not fully blinded.

2. Outcome assessment fully blinded.

Each criterion was scored from 0 to 2 , therefore a maximum score of 8 and a minimum score of zero could be achieved for each trial.

\section{Effects of interventions}

- Data abstraction.

For the 50 studies included in this review we found complete data on 24 studies (Barlow 1997; Barlow 2000; Bell 1998; Brus 1998; Geissner 1994; Hammond 1999; Helliwell 1999; Hewlett 1999; Hill 2001; Huiskes 1991; Leibing 1999; Lindroth 1997; Maisiak 1996b; Neuberger 1993; Parker 1988; Parker 1995; Radojevic 
1992; Riemsma 1999; Rodriguez 1996; Savelkoul 2001; Scholten 1999; Sharpe 2001; Stenstrom 1994; Taal 1993), 7 other studies gave some data but not complete (Appelbaum 1988; Helewa 1991; Kaplan 1981; Maisiak 1996a; O’Leary 1988; Rhodes 1988; Shearn 1985), we are still waiting for replies from some of the authors to requests for more information. For 2 studies we have no data yet (Cohen 1986; Daltroy 1998), but the authors replied that the information requested will be send as soon as possible. On 8 studies we found no data relating to the outcomes under investigation in the report (Balmer 1989; Branch 1999; Cziske 1987; Lorig 1999a; Lorig 1999b; Maggs 1996; Strauss 1986; Wetstone 1985), and the authors have not yet replied to our requests. Finally on 9 studies the relevant data are not available according to the authors (Bradley 1987; Fries 1997; Goeppinger 1989; Lorig 1985; Lorig 1986; Lorig 1989; McEvoy-DeVellis 1988; Oermann 1986; Parker 1984).

- Publication bias

Potential bias in meta-analytic research is publication bias, which occurs when trials showing no effect are selectively not published. One method used to detect publication bias is to plot study sample sizes versus effect sizes in a so-called funnel plot. A symmetric distribution of effect sizes, clustered around the effect sizes of the largest studies, would be expected in the absence of publication bias.

We have drawn funnel plots showing sample sizes versus effect sizes for the two outcomes that were assessed most often: pain and disability (see Figure 01 and 02).

- Quality assessment.

The quality of all 50 studies was assessed (Table 1). For the studies on which we had two publications or more we used all available information from all publications to assess the quality of each study. If it was possible to retrieve additional information from the authors concerning the quality of the study, this was incorporated in the score as well. If it was not possible to retrieve additional information, the quality score reported reflects the quality of the study as it is reported in the paper. This may not reflect the true quality of the study.

Table 1. Quality assessment for 50 included studies

\begin{tabular}{|c|c|c|c|c|c|}
\hline Study & Selection & Performance & Attrition & Blinding & Total score \\
\hline Brus 1998 & 0 & 1 & 1 & 2 & 4 \\
\hline Barlow 1997 & 0 & 0 & 0 & 0 & 0 \\
\hline Lindroth 1997 & 0 & 1 & 2 & 0 & 3 \\
\hline Fries 1997 & 1 & 1 & 2 & 1 & 5 \\
\hline
\end{tabular}

Copyright (c) 2009 The Cochrane Collaboration. Published by John Wiley \& Sons, Ltd. 
Table 1. Quality assessment for $\mathbf{5 0}$ included studies (Continued)

\begin{tabular}{|c|c|c|c|c|c|}
\hline Maggs 1996 & 0 & 0 & 1 & 0 & 1 \\
\hline Maisiak 1996a & 1 & 0 & 2 & 1 & 4 \\
\hline Parker 1995 & 0 & 1 & 1 & 1 & 3 \\
\hline Huiskes 1991 & 0 & 0 & 1 & 1 & 2 \\
\hline Stenstrom 1994 & 0 & 0 & 1 & 1 & 2 \\
\hline Geissner 1994 & 0 & 2 & 0 & 0 & 2 \\
\hline Neuberger 1993 & 0 & 0 & 0 & 0 & 0 \\
\hline Taal 1993 & 1 & 0 & 0 & 1 & 2 \\
\hline Helewa 1991 & 1 & 0 & 2 & 1 & 4 \\
\hline Goeppinger 1989 & 0 & 0 & 1 & 0 & 1 \\
\hline Lorig 1989 & 0 & 0 & 1 & 0 & 1 \\
\hline Parker 1988 & 1 & 0 & 1 & 0 & 2 \\
\hline O’Leary 1988 & 0 & 0 & 1 & 1 & 2 \\
\hline Bradley 1987 & 0 & 0 & 1 & 2 & 3 \\
\hline Strauss 1986 & 0 & 0 & 0 & 0 & 0 \\
\hline Lorig 1986 & 0 & 0 & 1 & 0 & 1 \\
\hline Cohen 1986 & 0 & 0 & 1 & 0 & 1 \\
\hline Wetstone 1985 & 0 & 0 & 1 & 1 & 2 \\
\hline Lorig 1985 & 0 & 0 & 1 & 0 & 1 \\
\hline Shearn 1985 & 0 & 0 & 0 & 0 & 0 \\
\hline Parker 1984 & 0 & 0 & 1 & 0 & 1 \\
\hline Kaplan 1981 & 0 & 0 & 1 & 1 & 2 \\
\hline $\begin{array}{l}\text { McEvoy-DeVellis } \\
1988\end{array}$ & 0 & 0 & 1 & 0 & 1 \\
\hline Balmer 1989 & 0 & 0 & 1 & 0 & 1 \\
\hline
\end{tabular}


Table 1. Quality assessment for $\mathbf{5 0}$ included studies (Continued)

\begin{tabular}{|c|c|c|c|c|c|}
\hline Rhodes 1988 & 0 & 0 & 0 & 1 & 1 \\
\hline Oermann 1986 & 0 & 0 & 1 & 0 & 1 \\
\hline Appelbaum 1988 & 0 & 0 & 0 & 0 & 0 \\
\hline Radejovic 1992 & 0 & 1 & 1 & 0 & 2 \\
\hline Cziske 1987 & 0 & 0 & 0 & 0 & 0 \\
\hline Maisiak 1996b & 0 & 1 & 1 & 2 & 4 \\
\hline Bell 1998 & 2 & 2 & 2 & 1 & 7 \\
\hline Riemsma 1999 & 0 & 0 & 2 & 1 & 3 \\
\hline Hewlett 1999 & 2 & 1 & 2 & 1 & 6 \\
\hline Savelkoul 2000 & 2 & 1 & 2 & 2 & 7 \\
\hline Rodriguez 1996 & 0 & 1 & 1 & 0 & 2 \\
\hline Barlow 2000 & 2 & 0 & 2 & 1 & 5 \\
\hline Branch 1999 & 0 & 0 & 0 & 0 & 0 \\
\hline Daltroy 1998 & 0 & 1 & 1 & 1 & 3 \\
\hline Hammond 1999 & 2 & 1 & 1 & 1 & 5 \\
\hline Helliwell 1999 & 2 & 2 & 2 & 1 & 7 \\
\hline Hill 2001 & 2 & 2 & 0 & 2 & 6 \\
\hline Leibing 1999 & 0 & 2 & 1 & 1 & 4 \\
\hline Lorig 1999a & 0 & 0 & 2 & 2 & 4 \\
\hline Lorig 1999b & 0 & 0 & 2 & 0 & 2 \\
\hline Scholten 1999 & 1 & 1 & 1 & 2 & 5 \\
\hline Sharpe 2001 & 2 & 0 & 2 & 1 & 5 \\
\hline $\begin{array}{l}\text { Total of all } 50 \text { stud- } \\
\text { ies }\end{array}$ & 22 & 22 & 52 & 34 & 130 \\
\hline
\end{tabular}


Table 1. Quality assessment for $\mathbf{5 0}$ included studies (Continued)

\begin{tabular}{|c|c|c|c|c|c|}
\hline $\begin{array}{l}\text { Total of } 31 \text { studies } \\
\text { with data }\end{array}$ & 21 & 20 & 33 & 27 & 101 \\
\hline
\end{tabular}

A separate analyses was undertaken including only the 17 studies with a quality score of 3 or higher and on which we have data (Barlow 2000; Bell 1998; Brus 1998; Hammond 1999; Helewa 1991; Helliwell 1999; Hewlett 1999; Hill 2001; Leibing 1999; Lindroth 1997; Maisiak 1996a; Maisiak 1996b; Parker 1995; Riemsma 1999; Savelkoul 2001; Scholten 1999; Sharpe 2001), to check whether the quality of studies seriously influences the results.

- Main results.

At first follow-up: We found significant effects of patient education at first follow-up for scores on disability (SMD $=-0.17$ [95\% CI: $-0.25,-0.09] ; \mathrm{Z}=3.97, \mathrm{P}=0.00007 ; \mathrm{N}=2275$ ), joint counts $(\mathrm{SMD}=-0.13$ [95\% CI: $-0.24,-0.01] ; \mathrm{Z}=2.14, \mathrm{P}=0.03 ; \mathrm{N}=$ 1158), patient global assessment (SMD $=-0.28$ [95\% CI: -0.49 , 0.07]; $\mathrm{Z}=2.65, \mathrm{P}=0.008 ; \mathrm{N}=358$ ), psychological status ( $\mathrm{SMD}=$ -0.15 [95\% CI: $-0.27,-0.04] ; Z=2.57, P=0.010 ; N=1138)$ and depression $(\mathrm{SMD}=-0.14$ [95\% CI: $-0.23,-0.05] ; \mathrm{Z}=2.90, \mathrm{P}=$ 0.004; $\mathrm{N}=1770$ ). Physician global assessment was not assessed in any of the included studies. One dimension of psychological status: anxiety showed no significant effects, nor did the dimensions of pain and disease activity. Although a trend was found in favour of patient education for pain: (SMD $=-0.08$ [95\% CI: $-0.16,0.00]$; $\mathrm{Z}=1.86, \mathrm{P}=0.06 ; \mathrm{N}=2229$ ) (See 'Tables of Comparisons').

Heterogeneity was not significant for all measures, therefore in all cases the fixed effect model was used.

At final follow up: No significant effects of patient education were found. Although a trend was seen in favour of patient education, for scores on disability: (SMD $=-0.09$ [95\% CI: $-0.20,0.02] ; Z=$ $1.66, \mathrm{P}=0.10 ; \mathrm{N}=1308)$. For all analyses the fixed effect model was used.

- Sensitivity analyses, using only one instrument for each outcome.

A way to reduce heterogeneity is using only one, the most common used, instrument to measure each outcome.

As mentioned before, the preliminary core set of outcomes identified by OMERACT include validated measures of pain, disability, joint pain/tenderness, joint swelling, patient and physician global assessment, and acute phase reactants, which were selected as outcome measures to be included in this review. We also included scores on psychological status, anxiety and depression.

PAIN. The most common instrument to measure pain was a visual analogue scale, which was used in 12 studies (Barlow 1997; Barlow 2000; Bell 1998; Hewlett 1999; Leibing 1999; Lindroth 1997; Neuberger 1993; Parker 1988; Parker 1995; Rhodes 1988; Rodriguez 1996; Shearn 1985) including 1112 patients. The visual analogue scale was most often a $10 \mathrm{~cm}$ horizontal line, anchored by 'no pain' on the left and 'pain as bad as it could be' on the right; although a $15 \mathrm{~cm}$ line, anchored by 'no pain' on the left and 'very severe pain' on the right, was used in one study (Shearn 1985 ); and in another study the $10 \mathrm{~cm}$ line was anchored by 'none' on the left and 'maximum imaginable' on the right (Bell 1998). Subjects were asked to place a mark on the line to describe the pain that they experienced yesterday, in the past week or in the past two weeks. In three studies the visual analogue pain scale used was not described (Hewlett 1999; Rhodes 1988; Rodriguez 1996). Other instruments were the AIMS2-pain scale, used in three studies ( Maisiak 1996a; Maisiak 1996b; Riemsma 1999), including 569 patients; the original AIMS-pain scale, also used in 3 studies ( Brus 1998; Radojevic 1992; Taal 1993) including 199 patients; as well as the IRGL-pain scale (Huiskes 1991), AES (Geissner 1994), MPQ (Appelbaum 1988), a scale to assess self-monitored level of subjective pain (Sharpe 2001), a HAQ-pain scale (Hammond 1999), a daily pain diary card (Hill 2001), an average pain scale (O'Leary 1988), and the SF-36 pain scale (Helliwell 1999), each used in 1 study including 18 to 130 patients.

Using the fixed effect model for pain measured with a VAS at first follow-up shows a significant effect of patient education: WMD $=-0.38$ [95\% CI: $-0.71,-0.05] ; \mathrm{Z}=2.27, \mathrm{P}=0.02 ; \mathrm{N}=1112$. Measured with the AIMS2 and AIMS-pain scales no significant effects of patient education were found.

At final follow-up no significant effects were found with any of the instruments.

DISABILITY: Disability was most often measured with the Health Assessment Questionnaire (HAQ). This instrument was used in 10 studies (Hammond 1999; Helliwell 1999; Helewa 1991; Hewlett 1999; Rodriguez 1996; Lindroth 1997; Scholten 1999; Sharpe 
2001; Shearn 1985; Stenstrom 1994) including 625 patients. The AIMS2-physical function scale was used in 3 studies (Maisiak 1996a; Maisiak 1996b; Riemsma 1999) including 559 patients; the Modified-HAQ was also used in 3 studies (Barlow 2000; Brus 1998; Taal 1993) including 301 patients; and the AIMSmobility scale was used in 2 studies (Parker 1988, Parker 1995) including 288 patients. Other instruments to measure disability, such as the SIP68 (the combined subscales: somatic autonomy, mobility control and mobility range) (Savelkoul 2001), the IRGL-mobility scale (Huiskes 1991), the AIMS-function scale (combined subscales: mobility, physical activity, dexterity, household activities and activities of daily living) (Radojevic 1992), Behinderungserleben (Geissner 1994), the MHQ-physical function scale (Rhodes 1988), the Disease Activities Questionnaire (DAQ) (Appelbaum 1988) and the Hannover Functional Ability Questionnaire (Leibing 1999) were used in 1 study each, including 18 to 138 patients. Helliwell et al. (Helliwell 1999) used the SF-36 physical function scale at final follow-up only, involving $73 \mathrm{pa}-$ tients; while O'Leary et al. (O'Leary 1988) used the HAQ at final follow-up only, involving 24 patients.

At first follow-up the HAQ showed a trend in favour of patient education: $\mathrm{WMD}=-0.19$ [95\% CI: $-0.39,0.01] ; \mathrm{Z}=1.87 ; \mathrm{P}=$ $0.06 ; \mathrm{N}=625$, using the random effects method since there was significant heterogeneity present. Excluding the study by Scholten et al. (Scholten 1999), the heterogeneity disappears, but so does the significance of the trend. The AIMS2-physical function scale did not show a significant effect of patient education at first followup.

At final follow-up the HAQ showed a significant effect for scores on disability in favour of patient education: WMD $=-0.11[95 \%$ CI: $-0.20,-0.01] ; Z=2.16 ; P=0.03 ; N=375$, using the fixed effects method. No significant effects were found with any of the other instruments at final follow-up.

JOINT COUNTS. Joint counts were most often assessed by means of the Ritchie Articular Index. This index was used in 8 studies (Bell 1998; Brus 1998; Helliwell 1999; Hill 2001; Rodriguez 1996; Sharpe 2001; Shearn 1985; Stenstrom 1994) including 548 patients. Joint counts as recommended by the ACR were used in 2 studies (Parker 1988; Parker 1995) involving 288 patients; the Thompson Articular Index was used in 2 studies (Hewlett 1999; Huiskes 1991) involving 144 patients. Two studies used the number of swollen joints (Leibing 1999; Radojevic 1992) involving 39 and 89 patients respectively; and one study used the and the 'Gelenkstatus' (Geissner 1994) involving 50 patients. At first follow-up Ritchie Articular Index scores showed a significant effect favouring patient education: WMD $=-1.79$ [95\% CI: -3.29, $0.29] ; Z=2.34, P=0.02 ; N=548$ ). No significant effects were found with any of the other instruments at first follow-up.

At final follow-up the Ritchie Articular Index showed a significant effect for scores on joint counts in favour of patient education:
WMD $=-1.55$ [95\% CI: $-3.08,-0.02] ; Z=1.99 ; P=0.05 ; \mathrm{N}$ $=472$, using the fixed effects method. No significant effects were found with any of the other instruments at final follow-up.

PATIENT GLOBAL ASSESSMENT. The AIMS-arthritis impact scale was most often used for the patient global assessment. It was used in 2 studies at first follow-up (Parker 1988; Taal 1993) involving 168 patients. Two other studies measured patient global assessment at first follow-up: Savelkoul et al. (Savelkoul 2001) measured patient global assessment in 103 patients, using one question: 'How do you rate your own health?' (answers ranging on a 5-point scale from 'very poor' to 'very good') and Barlow et al. (Barlow 2000) measured patient global assessment in 53 patients, using the EuroQoL VAS-general health scale. Two other studies measured patient global assessment at final follow-up only: Riemsma et al. (Riemsma 1999) used the AIMS-arthritis impact scale in 175 patients, and Helliwell et al. (Helliwell 1999) used the SF-36 general health perception scale in 72 patients.

At first follow-up patient global assessment scores, measured with either instrument, showed no significant effects.

At final follow-up no significant effects were found.

PSYCHOLOGICAL STATUS. Psychological status was most often measured with the AIMS2-affect scales. This instrument was used in 2 studies (Maisiak 1996b; Riemsma 1999) including 516 patients. The original AIMS-psychological status scales were also used in 2 studies (Parker 1995; Radojevic 1992) including 266 patients. Other instruments, such as the SIP68 (the combined subscales: 'psychological autonomy and communication' and 'emotional stability') (Savelkoul 2001), the IRGL-mood scale (Huiskes 1991), Schmerzbezogene Hilflosigkeit, Depression und Angst (HDA) (Geissner 1994) and MHQ-Emotion (Rhodes 1988) were used in 1 study each, including 38 to 138 patients. The SF-36 mental health scale was used in one study at final followup only (Helliwell 1999), including 68 patients.

At first follow-up scores on psychological status as measured with the AIMS2-affect scales showed no significant effects of patient education, while the AIMS-psychological status scales showed a trend favouring patient education: WMD $=-0.45$ [95\% CI: -0.90 , 0.00]; $\mathrm{Z}=1.98, \mathrm{P}=0.05 ; \mathrm{N}=266$. The other instruments showed no significant effects.

At final follow-up no significant effects were found.

ANXIETY. Anxiety was most often measured with the HAD-Anxiety scale. This instrument was used in 4 studies (Barlow 1997; Barlow 2000; Hewlett 1999; Sharpe 2001), including 375 patients. The original AIMS-anxiety scale was used in 3 studies (Brus 1998; Parker 1988; Taal 1993) including 220 patients. Other instruments, such as the AIMS2-stress scale (Riemsma 1999), STAIState Anxiety (Parker 1995; Leibing 1999), the SIP68-psychological autonomy and communcation scale (Savelkoul 2001), the IRGL-anxiety (Huiskes 1991) and Perceived stress (O’Leary 1988) 
were each used in 1 or 2 studies including 24 to 249 patients. None of the instruments showed significant effects at first followup, nor at final follow-up.

DEPRESSION. Depression was most often measured with the CES-D scale, this instrument was used in 4 studies (Neuberger 1993; Parker 1995; Radojevic 1992; Shearn 1985) including 437 patients. The HAD-depression scale was also used in 4 studies ( Barlow 1997; Barlow 2000; Hewlett 1999; Sharpe 2001) including 375 patients. The AIMS2-mood scale was used in 1 study ( Riemsma 1999) including 246 patients, while the original AIMSdepression scale was used in 3 studies (Brus 1998; Parker 1988; Taal 1993) including 221 patients. Other instruments to asses depression, such as the SIP68-emotional stability scale (Savelkoul 2001), the IRGL-depression scale (Huiskes 1991), the Beck-depression scale (Helewa 1991; Scholten 1999), the Zung-depression scale (Kaplan 1981; O’Leary 1988), and Von Zerssen's Depression Scale (Leibing 1999) were used in one or two studies each, involving 22 to 162 patients.

At first follow-up scores on depression as measured with the HADdepression scale showed significant effects in favour of patient education: $\mathrm{WMD}=-0.62$ [95\% CI: $-1.21,-0.02] ; \mathrm{Z}=2.04, \mathrm{P}=$ $0.04 ; \mathrm{N}=375$. None of the other instruments showed significant effects at first follow-up. At final follow-up no significant effects were found.

DISEASE ACTIVITY. ESR was used in 7 studies (Brus 1998; Geissner 1994; Huiskes 1991; Leibing 1999; Parker 1988; Sharpe 2001; Shearn 1985) involving 461 patients to assess disease activity. Four studies (Hewlett 1999; Hill 2001; Leibing 1999; Sharpe 2001) involving 201 patients used CRP to assess disease activity. Two studies (Helliwell 1999; Hill 2001) used plasma viscosity to assess disease activity.

Neither instrument showed significant effects at first follow-up, nor at final follow-up.

- Sensitivity analysis, using only one experimental condition for each study.

Some studies included two or three experimental conditions. Since we included comparisons of each experimental condition versus the control condition, the control conditions for these studies were included twice or three times, thus over-estimating the results of the control condition. To see whether this over-estimation seriously influenced results, we have done separate analysis including only one (the most extreme) educational intervention. This yielded the following results.

For most measures we found slightly more significant effects, but on the whole results were very similar. At first follow-up there remain significant effects of patient education for scores of disability $(\mathrm{SMD}=-0.23$ [95\% CI: $-0.36,-0.09] ; \mathrm{Z}=3.31, \mathrm{P}=0.0009 ; \mathrm{N}$
$=1578)$, joint counts $(\mathrm{SMD}=-0.15$ [95\% CI: $-0.30,-0.01] ; \mathrm{Z}=$ 2.14, $\mathrm{P}=0.03 ; \mathrm{N}=783)$, patient global assessment: $(\mathrm{SMD}=-0.30$ [95\% CI: $-0.55,-0.04] ; Z=2.25, P=0.02 ; N=236$ ), and depression: $(\mathrm{SMD}=-0.18$ [95\% CI: $-0.30,-0.07] ; \mathrm{Z}=3.09, \mathrm{P}=0.002$; $\mathrm{N}=1189)$. There were trends in favour of patient education for pain: $(\mathrm{SMD}=-0.10$ [95\% CI: $-0.20,0.00] ; \mathrm{Z}=1.91, \mathrm{P}=0.06 ; \mathrm{N}$ $=1538)$, and psychological status: $(\mathrm{SMD}=-0.16$ [95\% CI: -0.33 , $0.01] ; Z=1.88, P=0.06 ; N=538)$. For all analyses the fixed effect model was used, except for scores on disability where the random effect method was used, because of significant heterogeneity.

At final follow-up, no significant effects of patient education were found. However we did find trends in favour of patient education for scores on pain (SMD $=-0.13$ [95\% CI: $-0.28,0.02] ; Z=1.65$, $\mathrm{P}=0.10 ; \mathrm{N}=680)$, disability (SMD $=-0.12$ [95\% CI: -0.25 , $0.02] ; \mathrm{Z}=1.68, \mathrm{P}=0.09 ; \mathrm{N}=851$ ), and depression $(\mathrm{SMD}=-$ 0.14 [95\% CI: $-0.29,0.01] ; Z=1.79, P=0.07 ; \mathrm{N}=678$ ). For all analyses the fixed effect model was used.

- Sensitivity analysis, using only high quality studies.

We have done a separate analysis including only studies with a quality score of 3 or more points (Barlow 2000; Bell 1998; Brus 1998; Hammond 1999; Helewa 1991; Helliwell 1999; Hewlett 1999; Hill 2001; Leibing 1999; Lindroth 1997; Maisiak 1996a; Maisiak 1996b; Parker 1995; Riemsma 1999; Savelkoul 2001; Scholten 1999; Sharpe 2001). This yielded the following results.

At first follow-up there is a significant effect of patient education for scores of disability (SMD $=-0.20$ [95\% CI: $-0.35,-0.05]$; Z $=2.55, \mathrm{P}=0.01 ; \mathrm{N}=1586$ ), patient global assessment (SMD $=-0.32[95 \% \mathrm{CI}:-0.60,-0.03] ; \mathrm{Z}=2.15, \mathrm{P}=0.03 ; \mathrm{N}=190)$, psychological status (SMD $=-0.18$ [95\% CI: $-0.31,-0.04] ; Z=$ 2.54, $\mathrm{P}=0.01 ; \mathrm{N}=831$ ), and depression (SMD $=-0.21[95 \% \mathrm{CI}$ : -0.32, -0.09]; $\mathrm{Z}=3.38, \mathrm{P}=0.0007 ; \mathrm{N}=1105$ ). For pain, joint counts, anxiety and disease activity we did not find a significant effect or trend. For all analyses the fixed effect model was used, except for scores on disability, where the random effects method was used since there was significant heterogeneity present.

At final follow-up, no significant effects of patient education were found. For all analyses the fixed effect model was used.

- Sensitivity analysis, using only large studies $(\mathrm{N}>80)$.

We have done separate analysis including only studies with more than 80 participants (Barlow 1997; Barlow 2000; Bell 1998; Helewa 1991; Huiskes 1991; Lindroth 1997; Maisiak 1996b; Parker 1988; Parker 1995; Riemsma 1999; Savelkoul 2001; Shearn 1985). This yielded the following results.

At first follow-up there is a significant effect of patient education for scores of disability (SMD $=-0.15$ [95\% CI: $-0.25,-0.05]$; $\mathrm{Z}=$ 
2.88, $\mathrm{P}=0.004 ; \mathrm{N}=1514$ ), patient global assessment $(\mathrm{SMD}=-$ 0.31 [95\% CI: $-0.57,-0.06$ ]; $\mathrm{Z}=2.46, \mathrm{P}=0.01, \mathrm{~N}=248$ ), and depression (SMD $=-0.13$ [95\% CI: $-0.25,-0.02$ ]; $\mathrm{Z}=2.24, \mathrm{P}=$ $0.02 ; \mathrm{N}=1183)$. For scores on psychological status there is still a trend: $(\mathrm{SMD}=-0.13$ [95\% CI: $-0.25,0.00] ; \mathrm{Z}=1.96, \mathrm{P}=0.05$; $\mathrm{N}=961$ ). For joint counts we no longer found a significant effect. For all analyses the fixed effect model was used.

At final follow-up no significant effects of patient education were found. For all analyses the fixed effect model was used.

- Sensitivity analysis, using results at a fixed point in time (24 months).

In the analysis so far we have clustered results at first follow-up and results at final follow-up. However there are great differences between studies: in one study first follow-up assessments were done after 3 weeks (Barlow 1997), in another after 9 months (Maisiak 1996b). Final follow-up assessments were assessed after 3 months in one study (Radojevic 1992) and after 14 months in another ( Taal 1993).

In order to make study effects more comparable we selected results of all studies at a certain point in time. In most studies assessments were done between 8 weeks and 4 months; this included first follow-up results in 16 studies (Appelbaum 1988; Barlow 2000; Brus 1998; Hammond 1999; Hewlett 1999; Huiskes 1991; Kaplan 1981; Leibing 1999; Lindroth 1997; Neuberger 1993; Rhodes 1988; Riemsma 1999; Savelkoul 2001; Sharpe 2001; Shearn 1985; Stenstrom 1994), final follow-up results in one study (Radojevic 1992) and second follow-up results in three studies (Parker 1995; Scholten 1999; Taal 1993).

We found a significant effect of patient education at three months follow-up for scores on disability (SMD $=-0.14$ [95\% CI: -0.24 , -0.04]; $\mathrm{Z}=2.68, \mathrm{P}=0.007 ; \mathrm{N}=1557$ ) and depression ( $\mathrm{SMD}=$ -0.11 [95\% CI: $-0.22,-0.01$ ] $; Z=2.17, \mathrm{P}=0.03 ; \mathrm{N}=1468)$. In addition, we found trends for scores on pain (SMD $=-0.10[95 \%$ CI: $-0.21,0.01] ; Z=1.83, P=0.07 ; \mathrm{N}=1399$ ), joint counts (SMD $=-0.17$ [95\% CI: $-0.38,0.03] ; Z=1.65, P=0.10 ; \mathrm{N}=731$ ) and patient global assessment $(\mathrm{SMD}=-0.22$ [95\% CI: $-0.47,0.03] ; \mathrm{Z}$ $=1.69, \mathrm{P}=0.09 ; \mathrm{N}=247)$. Physician global assessment was not assessed in any of the included studies. Psychological status and anxiety showed no significant effects nor did the scores on disease activity.

Heterogeneity was significant for measures of joint counts (Chisquare $=26.68, \mathrm{P}=0.02$ ), so in this case the random effect model was used, in all other analyses the fixed effect model was used.

- Sensitivity analysis, using studies with comparable interventions.
In the analyses so far we have considered the interventions to be comparable. However there are great differences between the interventions. The 31 studies from which data could be retrieved include 76 treatment arms, 31 of which are control conditions. The 45 experimental conditions can be divided in three groups: 'Information only', 'Counselling' and 'Behavioural Treatment'.

'Information only' included all interventions aimed primarily at the exchange of information, by means of persuasive communication or informational brochures; these interventions do not include a behavioural component and are not aimed at generating support. 'Counselling' includes interventions mainly aimed at social support and giving patients the opportunity to discuss their problems. 'Behavioural Treatment' refers to interventions that include techniques aimed at behavioural change, such as behavioural instruction, skills training and biofeedback.

'Information only' includes 9 experimental interventions: Barlow 1997; Helliwell 1999; Hill 2001; Maisiak 1996b (Symptom Monitoring); Neuberger 1993 (C-Self Instruction); Parker 1988 (Attention Placebo); Parker 1995 (Patient Education Course); Radojevic 1992 (Education Family Support) \& Rodriguez 1996.

Counselling includes 5 experimental interventions: Kaplan 1981; Maisiak 1996a; Maisiak 1996b (Treatment Counselling); Savelkoul 2001 (Mutual Support) \& Shearn 1985 (Mutual Support).

Behavioural Treatment includes the remaining 31 experimental interventions: Appelbaum 1988; Barlow 2000; Bell 1998; Brus 1998; Geissner 1994 (Multimodal Pain Management; Visualisation Techniques and Relaxation Training); Hammond 1999; Helewa 1991; Hewlett 1999; Huiskes 1991 (Combination Therapy; Cognitive Behavioural Therapy and Occupational Therapy); Leibing 1999; Lindroth 1997; Neuberger 1993 (A-nurse patient contracts and B-practice time and demonstrations); O'Leary 1988; Parker 1988 (Cognitive-Behavioural Group); Parker 1995 (StressManagement Course); Radojevic 1992 (Behavioural Therapy with Family Support and Behavioural Therapy without Family Support); Rhodes 1988; Riemsma 1999 (Group Education with Partner and Group Education without Partner); Savelkoul 2001 (Coping Intervention Group); Scholten 1999; Sharpe 2001; Shearn 1985 (Self-Management); Stenstrom 1994 \& Taal 1993.

Information only.

Since there were only 9 treatment arms with Information-only interventions, effects have to be interpreted with caution due to lower numbers of respondents. No significant effects of Information only were found at first follow-up. However, pain and psychological status showed a trend in favour of the Information-only group: pain: (SMD $=-0.15$ [95\% CI: $-0.32,0.02] ; \mathrm{Z}=1.71, \mathrm{P}=$ $0.09 ; \mathrm{N}=524)$ and psychological status: (SMD $=-0.24$ [95\% CI: -0.48, 0.01]; $Z=1.88, P=0.06 ; N=257$ ). 
Patient global assessment was assessed in one study only (Parker 1988), which showed no significant effect. Physician global assessment was not assessed in any of the included studies. Heterogeneity was not significant for any measure, so in all analyses the fixed effect model was used.

At final follow up no significant effects of Information only were found. For all analyses the fixed effect model was used.

\section{Counselling.}

There were only 5 treatment arms with counselling interventions, so effects have to be interpreted cautiously again due to lower numbers of participants. No significant effects of counselling were found at first follow-up for any measure. However a trend was found for scores on psychological status (SMD $=-0.25[95 \% \mathrm{CI}$ : -0.52, 0.03]; $\mathrm{Z}=1.74, \mathrm{P}=0.08 ; \mathrm{N}=203$ ).

Patient global assessment, anxiety, joint counts and disease activity were assessed in one study only (the first two in Savelkoul 2001 and the latter two in Shearn 1985), neither showed a significant effect. The remaining measures: pain and disability showed no significant effects.

Heterogeneity was significant for measures of pain (Chi-square $=$ $6.14, \mathrm{P}=0.05$ ), so in this case the random effect model was used, in all other analyses the fixed effect model was used.

At final follow up disability, patient global assessment, psychological status, anxiety and depression were assessed in one study only (Savelkoul 2001), neither showed a significant effect. For the remaining measures: pain, joint counts and disease activity no assessments were found. For all analyses the fixed effect model was used.

Behavioural Treatment.

We found a significant effect of behavioural treatment interventions at first follow-up for scores on disability (SMD $=-0.23[95 \%$ CI: $-0.36,-0.10] ; Z=3.52, P=0.0004 ; \mathrm{N}=1532$ ), patient global assessment $(\mathrm{SMD}=-0.30$ [95\% CI: $-0.55,-0.04] ; \mathrm{Z}=2.25, \mathrm{P}=$ $0.02 ; \mathrm{N}=236)$ and depression (SMD $=-0.14$ [95\% CI: -0.25 , $0.04] ; Z=2.63, P=0.009 ; N=1350$ ). Furthermore a trend was found for scores on pain (SMD $=-0.09$ [95\% CI: $-0.19,0.02$ ]; Z $=1.67, \mathrm{P}=0.10 ; \mathrm{N}=1453)$. Physician global assessment was not assessed in any of the included studies. Joint counts, psychological status, anxiety, and disease activity showed no significant effects.

Heterogeneity was significant for measures of disability (Chisquare $=26.68, \mathrm{P}=0.02$ ), so in this case the random effect model was used, in all other analyses the fixed effect model was used.

At final follow up no significant effects of behavioural treatment were found. However trends in favour of behavioural treatment was found for scores on disability (SMD $=-0.10$ [95\% CI: -0.23 , $0.02] ; \mathrm{Z}=1.64, \mathrm{P}=0.10 ; \mathrm{N}=1003)$ and depression (SMD = 0.12 [95\% CI: $-0.25,0.01$ ]; $Z=1.80, P=0.07 ; \mathrm{N}=911$ ). For all analyses the fixed effect model was used.

\section{I S C U S S I O N}

- Publication bias.

We have drawn funnel plots showing sample sizes versus effect sizes for the two outcomes that were assessed most often: pain and disability (see Figure 01 and 02 ). Both plots seem to suggest that there is no publication bias. Smaller studies with negative outcomes are as well represented as smaller studies favouring patient education.

The 'true effect size' for pain centres round -0.08 (95\% CI: -0.16, 0.00 ), which is similar to the pooled effect size of the four largest studies: -0.06 (95\% CI: $-0.22,0.11)$; while the 'true effect size' for disability centres round -0.17 (95\% CI: $-0.25,-0.09)$, which is slightly more favourable for patient education compared to the pooled effect size of the four largest studies: -0.13 (95\% CI: -0.30 , $0.04)$.

- Quality assessment.

The quality of studies on average was not very high. The mean score from all 50 studies was 2.60 (out of a possible 8); the mean score for the 31 studies with data included in this review was 3.26 (out of 8).

Of all 50 Randomised Controlled Trials, only eight received the full 2 points for the description of the randomisation procedure; only six other studies received one point for randomisation, making 'randomisation' together with 'co-interventions' the two least well-reported elements of the four quality items with a mean of 0.44 (out of a possible score of 2) for both. Most studies scored higher on attrition; with a mean of 1.04 (out of 2), this item showed the highest scores of the quality items.

The quality as reported in the included reports seems rather low. However the reported quality of papers may not reflect the true quality of the study. We did make an effort to ask authors for any missing details, but in many cases data were no longer available or authors could not be reached. The following authors were contacted: Barlow (Barlow 1997), Bradley (Bradley 1987), Brus (Brus 1998), Daltroy (Daltroy 1998), Fries (Fries 1997), Geissner (Geissner 1994), Goeppinger (Goeppinger 1989), Hammond (Hammond 1999), Helewa (Helewa 1991), Helliwell (Helliwell 1999), Hewlett (Hewlett 1999), Hill (Hill 2001), Kraaimaat (Huiskes 1991), Lindroth (Lindroth 1997), Lorig ( Lorig 1985, Lorig 1986, Lorig 1989), Maisiak (Maisiak 1996a, Maisiak 1996b), McEvoy-De Vellis (Cohen 1986, McEvoyDeVellis 1988), Oermann (Oermann 1986), Smarr \& Hewett (Parker 1984, Parker 1988, Parker 1995), Riemsma (Riemsma 1999), Savelkoul (Savelkoul 2001), Scholten (Scholten 1999), Sharpe (Sharpe 2001), Stenstrom (Stenstrom 1994), Taal (Taal 1993) and Wright (Barlow 2000). 
One of the two least well-reported elements of the four quality items was randomisation. Although all studies claim to be randomised controlled trials, only eight out of 50 studies gave a complete description of the randomisation process. Only five studies clearly stated that other interventions were not allowed during the intervention period, and only seven studies clearly described efforts undertaken to blind patients, education providers and outcome assessors. Although it is impossible to blind patients and education providers for the condition they are in, it is possible to blind them for the purpose of the study, points were allocated for the efforts the authors undertook to establish this.

It is important for both authors and journal editors to acknowledge that a clear presentation of the methodology of a study is vital for readers to understand the value of the report.

Comparison of our findings with other studies is difficult as the quality assessments used differ considerably. However most systematic reviews of educational interventions reported similar methodological quality of trials (Gibson 2001; Holloway 2001; Karjalainen 2001a; Karjalainen 2001b; Lancaster 2001; van Tulder MW 2001).

In the latest update of this review we have added 11 new studies. The quality scores for these 11 new studies are considerably higher than those of the original 39 studies. The mean score from all 11 new studies was 4.18 compared to 2.15 (out of a possible 8 ) for the original 39 studies. This seems a very positive improvement, and is encouraging for the future.

- Main results

For the outcome measures included in this analysis there was a small beneficial effect of patient education at first follow-up for pain (4\%), disability (10\%), joint counts $(9 \%)$, patient global assessment (12\%), psychological status (5\%) and depression (12\%). At final follow-up (3-18 months) no significant effects were found in the main analyses, only a trend for scores on disability favouring patient education. Detailed results are provided below for each outcome. The results are summarised in Table 2 and Table 3.

Table 2. Summary of significant results at first follow-up (trends in brackets)

\begin{tabular}{|c|c|c|c|c|c|c|c|c|c|}
\hline & Measure & Pain & Disability & $\begin{array}{l}\text { Joint } \\
\text { counts }\end{array}$ & $\begin{array}{l}\text { Patient } \\
\text { Global A. }\end{array}$ & $\begin{array}{l}\text { Psycho- } \\
\text { logical sta- } \\
\text { tus }\end{array}$ & Anxiety & Depression & $\begin{array}{l}\text { Disease ac- } \\
\text { tivity }\end{array}$ \\
\hline $\begin{array}{l}\text { Main anal- } \\
\text { ysis }\end{array}$ & SMD & $(-0.08)$ & -0.17 & -0.13 & -0.28 & -0.15 & & -0.14 & \\
\hline $\begin{array}{l}\text { SA: One } \\
\text { instru- }\end{array}$ & WMD & $\begin{array}{l}-0.38 \quad- \\
\text { VAS }\end{array}$ & $\begin{array}{l}(-0.19 \\
\mathrm{HAQ})\end{array}$ & $\begin{array}{l}-1.79 \\
\text { Ritchie }\end{array}$ & & $\begin{array}{l}(-0.45- \\
\text { AIMS-Psy) }\end{array}$ & & $\begin{array}{l}-0.62 \\
\text { HAD-Dep }\end{array}$ & \\
\hline
\end{tabular}


Table 2. Summary of significant results at first follow-up (trends in brackets) (Continued)

\begin{tabular}{|c|c|c|c|c|c|c|c|}
\hline ment & & & & & & & \\
\hline $\begin{array}{l}\text { SA: } \\
\text { One exper- } \\
\text { imental } \\
\text { condition }\end{array}$ & SMD & $(-0.10)$ & -0.23 & -0.15 & -0.30 & $(-0.16)$ & -0.18 \\
\hline $\begin{array}{l}\text { SA: High } \\
\text { Quality } \\
\text { studies }\end{array}$ & SMD & & -0.20 & & -0.32 & -0.18 & -0.21 \\
\hline $\begin{array}{l}\text { SA: Large } \\
\text { studies }\end{array}$ & SMD & & -0.15 & & -0.31 & $(-0.13)$ & -0.13 \\
\hline $\begin{array}{l}\text { SA: } \quad 2-4 \\
\text { months re- } \\
\text { sults }\end{array}$ & SMD & $(-0.10)$ & -0.14 & $(-0.17)$ & $(-0.22)$ & & -0.11 \\
\hline $\begin{array}{l}\text { SA: Infor- } \\
\text { mation } \\
\text { only }\end{array}$ & SMD & $(-0.15)$ & & & & $(-0.24)$ & \\
\hline $\begin{array}{l}\text { SA: Coun- } \\
\text { selling }\end{array}$ & SMD & & & & & $(-0.25)$ & \\
\hline $\begin{array}{l}\text { SA: Behav- } \\
\text { ioral treat- } \\
\text { ment }\end{array}$ & SMD & $(-0.09)$ & -0.23 & & -0.30 & & -0.14 \\
\hline
\end{tabular}

Table 3. Summary of significant results at final follow-up (trends in brackets)

\begin{tabular}{|c|c|c|c|c|c|c|c|c|c|}
\hline & Measure & Pain & Disability & $\begin{array}{l}\text { Joint } \\
\text { counts }\end{array}$ & $\begin{array}{l}\text { Patient } \\
\text { Global A. }\end{array}$ & $\begin{array}{l}\text { Psycholog- } \\
\text { ical status }\end{array}$ & Anxiety & Depression & $\begin{array}{l}\text { Disease activ- } \\
\text { ity }\end{array}$ \\
\hline $\begin{array}{l}\text { Main anal- } \\
\text { ysis }\end{array}$ & SMD & & $(-0.09)$ & & & & & & \\
\hline $\begin{array}{l}\text { SA: One } \\
\text { instru- } \\
\text { ment }\end{array}$ & WMD & & $\begin{array}{l}-0.11 \\
\mathrm{HAQ}\end{array}$ & $\begin{array}{l}-1.55 \\
\text { Ritchie }\end{array}$ & & & & & \\
\hline $\begin{array}{l}\text { SA: } \\
\text { One exper- } \\
\text { imental } \\
\text { condition }\end{array}$ & SMD & $(-013)$ & $(-0.12)$ & & & & & $(-0.14)$ & \\
\hline
\end{tabular}

SA: High SMD

Quality studies 
Table 3. Summary of significant results at final follow-up (trends in brackets) (Continued)

\begin{tabular}{l}
\hline $\begin{array}{l}\text { SA: Large } \\
\text { studies }\end{array}$ \\
\hline $\begin{array}{l}\text { SA: Infor- SMD } \\
\text { mation } \\
\text { only }\end{array}$
\end{tabular}

PAIN:

Overall, we only found a trend in favour of patient education at first follow-up for scores on pain.

Pain measured with a VAS shows a significant effect of patient education at first follow-up. Measured with the AIMS2 and AIMSpain scales no significant effects of patient education were found.

Two sensitivity analyses showed a trend in favour of patient education for scores on pain: using results after 3 months, and using only one experimental condition for each study.

Using only high quality studies or only large studies, we did not find a significant effect or trend for pain.

The Visual Analogue Scale showed the most significant effects for the measurement of pain, perhaps this instrument is most sensitive to changes due to educational interventions.

These results suggest a small, non-significant effect of patient education for scores on pain. A standard mean difference of 0.08 in favour of patient education can be translated into an improvement on a $10-\mathrm{cm}$ VAS (range $0-10 \mathrm{~cm}$ ) of $0.20 \mathrm{~cm}$, assuming that the mean score in the control group remains the same and a standard deviation of 2.50 in both groups. Assuming a start level of 4.70 on the VAS, an SMD of -0.08 translates into a 4\% (95\% CI: 0\%, 9\%) improvement on the VAS.

\section{DISABILITY:}

Overall, we found a small but significant effect of patient education at first follow-up for scores on disability.
Separate analyses of disability measured with the HAQ showed a trend in favour of patient education at first follow-up. Disability measured with the AIMS2-physical function scale showed no significant effects of patient education.

Sensitivity analyses, using only one experimental condition for each study, high quality studies only, large studies only and results after 3 months all showed significant effects of patient education on scores of disability.

These results suggest significant effects of patient education for scores on disability, and moreover these effects are quite robust, as most sensitivity analyses show significant effects. However, standardised effect sizes ranged from -0.11 to -0.23 (WMD $=-0.19$ equals to $\mathrm{SMD}=-0.11$ ), indicating that the effect is very small. A standard mean difference of 0.17 in favour of patient education can be translated into an improvement on Stanford Health Assessment Questionnaire (range 0-3) of 0.10, assuming that the mean score in the control group remains the same and a standard deviation of 0.60 in both groups. Assuming a start level of 1.00 on the HAQ, an SMD of -0.16 translates into a $10 \%$ (95\% CI: 5\%, $15 \%)$ improvement on the HAQ.

\section{JOINT COUNTS:}

We found a significant effect of patient education at first followup for scores on joint counts.

The Ritchie Articular Index was the only instrument showing a significant effect favouring patient education.

Sensitivity analysis using only one experimental condition for each study showed a significant effect as well, while results after 3 
months showed a trend favouring patient eduction.

The sensitivity analyses using only high quality studies and large studies did not show a significant effect or trend.

These results suggest a significant effect of patient education for scores on joint counts. The effects are not very robust, because the most important sensitivity analyses, using high quality studies only or large studies, showed no significant effects. Standardised effect sizes ranged from -0.13 to -0.20 (WMD $=-1.79$ equals to $\mathrm{SMD}=-0.20$ ), indicating that the effect size is small.

A standard mean difference of 0.13 in favour of patient education can be translated into an improvement on the Ritchie Articular Index (range: 0-78) of 1.3, assuming that the mean score in the control group remains the same and a standard deviation of 10.00 in both groups. Assuming a start level of 15.00 on the RAI, an SMD of -0.13 translates into a $9 \%(95 \%$ CI: $1 \%, 16 \%)$ improvement on the RAI.

\section{PATIENT GLOBAL ASSESSMENT:}

We found a significant effect of patient education at first followup for scores on patient global assessment.

Separate analyses of patient global assessment measured with the AIMS-arthritis impact scale, with a single question (Savelkoul 2001), and with the EuroQoL VAS-general health scale showed no significant effects.

Sensitivity analysis using only high quality studies, using only large studies, and with only one experimental condition for each study all showed a significant effect of patient education for scores of patient global assessment, while effects after 3 months showed a trend favouring patient education.

These results suggest significant effects of patient education for scores on patient global assessment, and the effects are quite robust. Standardised effect sizes ranged from -0.22 to -0.32 , indicating that the effect is small.

A standard mean difference of 0.28 in favour of patient education can be translated into an improvement on the AIMS-Arthritis Impact scale (range $0-10$ ) of 0.5 , assuming that the mean score in the control group remains the same and a standard deviation of 2.00 in both groups. Assuming a start level of 4.50 on the Arthritis Impact scale, an SMD of -0.28 translates into a $12 \%(95 \% \mathrm{CI}$ : $3 \%, 22 \%)$ improvement on the Arthritis Impact scale.

\section{PHYSICIAN GLOBAL ASSESSMENT:}

Physician global assessment was not assessed in any of the included studies.

\section{PSYCHOLOGICAL STATUS:}

We found a small, but significant effect of patient education at first follow-up for scores on psychological status.
The AIMS-psychological status scales showed a trend favouring patient education. The other instrument showed no significant effects.

Sensitivity analysis using only high quality studies showed a significant effect of patient education for scores of psychological status, while analyses using only one experimental condition for each study and using only large studies showed a trend favouring patient education.

Sensitivity analyses using results after 3 months showed no significant effect.

These results suggest small, but significant effects of patient education for scores on psychological status, the effects are still present in the analysis with high quality studies only, while large studies showed a trend favouring patient education. Standardised effect sizes ranged from -0.13 to -0.26 (WMD=-0.45 equals $S M D=-$ 0.26 ), indicating that the effect is very small.

A standard mean difference of 0.15 in favour of patient education can be translated into an improvement on the AIMS2-Affect scale (range $0-10$ ) of 0.20 , assuming that the mean score in the control group remains the same and a standard deviation of 1.40 in both groups. Assuming a start level of 4.10 on the AIMS2-Affect scale, an SMD of -0.15 translates into a 5\% (95\% CI: 1\%, 9\%) improvement on the AIMS2-Affect scale.

\section{ANXIETY:}

We found no significant effects for scores on anxiety at first followup, nor did any of the sensitivity analyises show a significant effect for scores on anxiety.

\section{DEPRESSION:}

We found a significant effect favouring patient eduation for scores on depression. Separate analyses of depression measured with the HAD-Depression scale also showed a significant effect, and all four sensitivity analyses showed significant effects favouring patient education.

These results suggest a significant effect of patient education for scores on depression, and the effects are quite robust. Standardised effect sizes ranged from -0.11 to -0.21 , indicating that the effect is very small.

A standard mean difference of 0.14 in favour of patient education can be translated into an improvement on the CES-Depression scale (range: $0-60$ ) of 1.6, assuming that the mean score in the control group remains the same and a standard deviation of 11.00 in both groups. Assuming a start level of 13.00 on the CES-Depression scale, an SMD of -0.14 translates into a $12 \%$ (95\% CI: $4 \%, 19 \%)$ improvement on the CES-Depression scale.

\section{DISEASE ACTIVITY:}


We found no significant effects for scores on disease activity at first follow-up, nor did any of the sensitivity analyses show a significant effect for scores on disease activity.

\section{FINAL FOLLOW UP:}

At final follow up, the main analyses showed no significant effects of patient education on any outcome. However, the main analyses did show a trend favouring patient education for scores on disability; and we did find significant effects favouring patient education for scores on disability using the HAQ and for joint counts using the Ritchie Articular Index. One of the sensitivity analyses (using only one experimental condition for each study) showed trends favouring patient education for scores on pain, disability and depression at final follow-up.

- Analysis by type of intervention.

Behavioural treatment was the only type of intervention that showed significant effects. Detailed results of the three types of intervention are given below.

\section{INFORMATION ONLY:}

Interventions aimed at information only, showed no significant effects for scores on pain, disability, joint counts, patient global assessment, anxiety, depression and disease activity. However, scores on pain and psychological status showed a trend in favour of the information-only group. At final follow up no significant effects or trends were found.

\section{COUNSELLING:}

Interventions aimed at counselling showed no significant effects for scores on pain, disability, joint counts, patient global assessment, anxiety, depression and disease activity. However, a trend was found for scores on psychological status. At final follow up no significant effects or trends were found.

\section{BEHAVIOURAL TREATMENT:}

Interventions aimed at behavioural treatment showed significant effects for scores on disability, patient global assessment and depression. A trend favouring behavioural treatment was found for scores on pain. No significant effects or trends were found for scores on joint counts, psychological status, anxiety and disease activity.

These results suggest that behavioural treatment has significant effects favouring behavioural treatment. However the effects are very small.

At final follow trends favouring behavioural treatment were found for scores on disability and depression.

- Comparison with other reviews
There has been increasing research in the field of patient education, and major reviews of published studies have been conducted on the value of education in general (Mazzuca 1982) and more recently on education in arthritis (Hirano 1994; Hawley 1995; Superio 1996; Taal 1997). Two reviews on arthritis patient education reported combined effect estimates on main outcomes, such as pain, disability and psychological outcomes (Hawley 1995; Superio 1996).

Superio-Cabuslay compared the effects of 19 patient education trials and 28 non-steroidal anti-inflammatory drug trials amongst patients with OA and RA between 1966 and 1993. In the review by Superio-Cabuslay et al. also non-randomised controlled trials were included and studies which included both patients with RA and $\mathrm{OA}$ were categorised according to the more prevalent diagnosis, while in this review only RCTs were included and scores were not presented unless they only included patients with RA. Superio-Cabuslay et al. used the standardised gain difference as the measure of effect size, which is calculated as the change in the intervention group minus the change in the control group, divided by the pooled pre-treatment standard deviation.

Hawley reviewed 34 clinical trials of patient education performed between 1985 until 1995 that are specific to rheumatic disease. The review by Hawley et al. included a wide range of study designs (RCTs, non-randomised controlled trials and before-after design without controls), although the reported effect sizes were based on RCTs in patients with RA only. Hawley et al. reported effect sizes weighted for sample size, which are described as a unit-free, standardised measures of change.

For pain, we found a trend favouring patient education at first follow-up. Superio-Cabuslay et al. (Superio 1996) found a nonsignificant effect favouring patient education in RA patients (Effect size $=-0.18$ [95\% CI: $-0.64,0.28] ; \mathrm{N}=589$, approximately). Although the result is quite similar, it was based on different studies than the results from this review. Superio-Cabuslay et al. included two non-randomised controlled trials $(\mathrm{N}=179)$ that were excluded from this review (Lindroth 1989; Gerber 1987). The remaining 7 studies $/ 10$ treatment arms $(\mathrm{N}=410)$ were also included in this review; however these represented only $22 \%$ of the patients included in this review. Hawley et al (Hawley 1995) reported an average effect size for RA patients at post-intervention of 0.13 favouring patient education. This was based on 6 studies/11 treatment arms $(\mathrm{N}=381$, approximately). Two of these six studies were excluded from our review because they were not considered to be RCTs (Basler 1993; Furst 1987).

For scores on disability, we found a small but significant effect of patient education at first follow-up. Superio-Cabuslay et al. ( Superio 1996) found a non-significant effect favouring patient education in RA patients (Effect size $=-0.18$ [95\% CI: -0.54 , $0.18] ; \mathrm{N}=588$ ). Again, the effect size is quite similar. Hawley et al. found an average effect size for RA patients at post-intervention of 
0.16 favouring the control group. This was based on three studies (6 treatment arms $(\mathrm{N}>212)$, two of which were also included in our review (Radojevic 1992; Shearn 1985), although all five treatments arms of these two studies favour patient education in our review.

For joint counts, we found a significant effect of patient education at first follow-up. Superio-Cabuslay et al. (Superio 1996) found a non-significant effect favouring patient education in RA patients (Effect size $=-0.28$ [95\% CI: $-1.49,0.93] ; \mathrm{N}=375$ ).

We found a small, significant effect favouring patient eduation for scores on depression. Hawley et al. found a non-significant average effect size for RA patients at post-intervention of -0.01 favouring patient education.

- Clinical significance of effects.

The statistically significant benefits of patient education at first follow-up are modest (5-12\%). The most important benefit was for disability with an effect size of -0.17 . This compares with effect sizes for 'disease modifying' drug treatment such as -0.09 (95\% CI: -0.45,0.27) for antimalarials (Suarez-Almazor 2001a), 0.19 (95\% CI: -0.39,0.02) for auranofin (Suarez-Almazor 2001b), -0.29 (95\% CI: $-0.77,0.19)$ for penicillamine (Suarez-Almazor 2001c), -0.31 (95\% CI: $-1.06,0.44)$ for azathioprine (SuarezAlmazor 2001d), -0.78 (95\% CI: $-1.10,-0.47)$ for cyclosporin ( Wells 2001) and -1.48 (95\% CI: $-1.82,-1.14)$ for methotrexate ( Suarez-Almazor 2001e). Glucocorticoids, when given in addition to 'disease modifying' drugs, has a further effect size of -0.57 ( $95 \%$ CI: -0.92, -0.22) (Criswell 2001).

\section{A U THORS' CONCLUSIONS Implications for practice}

Patient education as provided in the studies reviewed here had small short-term effects on disability, joint counts, patient global assessment, psychological status and depression. In evaluating clinical effects of patient education, it must be taken into account that patient education was provided in addition to standard medical care so the effects of patient education are always supplementary to the benefits of standard medical care. There was no evidence of long term benefits. In all these studies, patients were invited to take part in an experimental procedure and randomised. This contrasts with routine clinical practice in which patients may be more likely to select themselves for education sessions.

\section{Implications for research}

Patient education has been advocated in arthritis for information provision itself, and for its therapeutic potential (Tucker 1991). In practice, many patient education programmes have not been disease specific and there has been the assumption that all benefits would be generic. This analysis raises doubts over the achievement of meaningful benefits in patients with RA specifically, who are recruited via invitation to participate usually through a hospital outpatient department. Future research should be disease specific, and should seek to identify patient characteristics that are relevant to beneficial outcomes from educational intervention. A review of educational benefits in other specific forms or arthritis, particularly osteoarthritis, would be worthwhile. Trials of education should include as outcome measures the 'core set' agreed by the OMERACT group (Tugwell 1993), together with measures of psychological status such as the HAD, AIMS2 scales and/or CESD.

\section{ACKNOWLEDGEMENTS}

The authors would like to thank the Cochrane Musculoskeletal Group editorial team for their time and effort in reviewing this document and we would like to thank the Dutch Cochrane Centre for their help and suggestions while writing the review.

\section{RE F E R E NCES}

\section{References to studies included in this review}

Appelbaum 1988 \{published data only\} Appelbaum KA, Blanchard EB, Hickling EJ, Alfonso M. Cognitive behavioral treatment of a veteran population with moderate to severe rheumatoid arthritis. Behavior Therapy 1988;19:489-502.

Balmer 1989 \{published data only\}

Balmer DH. The CARE project: The evaluation of group counseling as a therapeutic intervention for patients with rheumatoid arthritis. British Journal of Guidance and Counselling 1989;17(3):304-16.
Barlow 1997 \{published and unpublished data\}

Barlow JH. Personal communication January 281999.

* Barlow JH, Pennington DC, Bishop PE. Patient education leaflets for people with rheumatoid arthritis: a controlled study. Psychology, Health \& Medicine 1997;2(3):221-35.

Barlow JH, Wright CC. Knowledge in patients with rheumatoid arthritis: a longer term follow-up of a randomized controlled study of patient education leaflets. British Journal of Rheumatology 1998; 37(4):373-6.

Barlow 2000 \{published data only\}

* Barlow JH, Turner AP, Wright CC. A randomized controlled study of the Arthritis Self-Management Programme in the UK. 
Health Education Research 2000;15:665-80.

Chris Wright. Personal communication Coventry, 12 April 2002.

\section{Bell 1998 \{published data only\}}

Bell MJ, Lineker SC, Wilkins AL, Goldsmith CH, Badley EM. A randomized controlled trial to evaluate the efficacy of community based physical therapy in the treatment of people with rheumatoid arthritis. Journal of Rheumatology 1998;25:231-7.

\section{Bradley 1987 \{published data only\}}

Bradley LA. Personal communication Boston, November 151999. * Bradley LA, Young LD, Anderson KO, Turner RA, Agudelo CA, McDaniel LK, Pisko E, Semble EL, Morgan TM. Effects of psychological therapy on pain behavior of rheumatoid arthritis patients. Treatment outcome and six-month follow-up. Arthritis \& Rheumatism 1987;30(10):1105-14.

Bradley LA, Young LD, Anderson KO, Turner RA, Agudelo CA, McDaniel LK, Semble EL. Effects of cognitive-behavioral therapy on rheumatoid arthritis pain behavior: one-year follow-up. In: Dubner R, Gebhart GF, Bond MR editor(s). Proceedings of the Vth World Congress on Pain. Elsevier Publishers, 1988:310-14.

Bradley 1987-B \{published data only\}

Branch 1999 \{published data only\}

* Branch V, Lipsky K, Nieman T, Lipsky P. Positive impact of an intervention by arthritis patient educators on knowledge and satisfaction of patients in a rheumatology practice. Arthritis Care and Research 1999;12:370-5.

Brus 1998 \{published and unpublished data\}

* Brus HLM. Compliance and patient education in rheumatoid arthritis (thesis). Enschede: University of Twente, 1997. Brus HLM. Personal communication February 221999. Brus HLM, Van de Laar MAFJ, Taal E, Rasker JJ, Wiegman O. Effects of patient education on compliance with basic treatment regimens and health in recent onset active rheumatoid arthritis. Annals of Rheumatic Diseases 1998;57(3):146-51.

Cohen 1986 \{published data only\}

* Cohen JL, Van Houten-Sauter S, DeVellis RF, McEvoy-DeVellis B. Evaluation of arthritis self-management courses led by laypersons and by professionals. Arthritis \& Rheumatism 1986;29(3):388-93. McEvoy-DeVellis B. Personal communication December 111999

\section{Cohen 1986-B \{published data only\}}

\section{Cziske 1987 \{published data only\}}

Cziske R, Jaeckel W, Jacobi E. Effects of a short pain-coping training programme for RA-patients during rehabilitation [Effekt eines Kurztrainingsprogramms zur Schmerzbewaltigung bei Rheumapatienten wahrend der Rehabilitation]. Zeitschrift fur Klinische Psychologie 1987;16(2):115-23.

Daltroy 1998 \{published data only\}

* Daltroy LH, Morlino CI, Eaton HM, Poss R, Liang MH.

Preoperative education for total hip and knee replacement patients. Arthritis Care \& Research 1998;11:469-78.

Lawren Daltroy. Personal communication Boston, 12 July 2002.

Daltroy 1998-B \{published data only\}

Daltroy 1998-C \{published data only\}

\section{Fries 1997 \{published data only\}}

Fries JF. Personal communication December 161999.

* Fries JF, Carey C, McShane DJ. Patient education in arthritis: randomized controlled trial of a mail-delivered program. Journal of Rheumatology 1997;24(7):1378-83.

\section{Geissner 1994 \{published and unpublished data\}}

Geissner E. Personal communication February 261999.

* Geissner E, Jungnitsch G, Schmitz J. Psychological treatment approaches in pain. A comparative study of therapies in patients with chronic polyarthritis [Psychologische Behandlungsansatze bei Schmerz: Eine Therapievergleichsstudie an Patienten mit Chronischer Polyarthritis]. Z Klin Psychol Psychopathol Psychother 1994;42(4):319-38.

\section{Geissner 1994-B \{published data only\}}

\section{Geissner 1994-C \{published data only\}}

\section{Goeppinger 1989 \{published data only\}}

Goeppinger J. Personal communication April 191999.

* Goeppinger J, Arthur MW, Baglioni AJ, Brunk SE, Brunner CM. A reexamination of the effectiveness of self-care education for persons with arthritis. Arthritis \& Rheumatism 1989;32(6):706-16.

Goeppinger 1989-B \{published data only\}

Hammond 1999 \{published data only\}

Alison Hammond. Personal communication Derby, 27 June 2002. * Hammond A, Lincoln N, Sutcliffe L. A crossover trial evaluating an educational-behavioural joint protection programme for people with rheumatoid arthritis. Patient Education and Counseling 1999; 37:19-32.

\section{Helewa 1991 \{published data only\}}

Helewa A. Personal communication January 62000.

* Helewa A, Goldsmith CH, Lee P, Bombardier C, Hanes B, Smythe HA, Tugwell P. Effects of occupational therapy home service on patients with rheumatoid arthritis. Lancet 1991;337 (8755):1453-6.

\section{Helliwell 1999 \{published data only\}}

* Helliwell PS, O'Hara M, Holdsworth J, Hesselden A, King T, Evans P. A 12-month randomized controlled trial of patient education on radiographic changes and quality of life in early rheumatoid arthritis. Rheumatology (Oxford) 1999;38:303-8. Philip Helliwell. Personal communication Leeds, 13 July 2002.

\section{Hewlett 1999 \{unpublished data only\}} Hewlett S. Personal communication December 1998.

Hill 2001 \{published data only\}

* Hill J, Bird H, Johnson S. Effect of patient education on adherence to drug treatment for rheumatoid arthritis: A randomised controlled trial. Annals of the Rheumatic Diseases 2001; 60:869-75.

Jackie Hill. Personal communication Leeds, 3 April 2002.

\section{Huiskes 1991 \{published and unpublished data\}}

* Huiskes CJAE, Kraaimaat FW, Brons MR, Bijlsma JWJ. The effect of cognitive behaviour therapy and occupational therapy in patients with rheumatoid arthritis [Het effect van gedragstherapie 
en ergotherapie bij patienten met reumatoide artritis]. Gedragstherapie 1991;24(4):253-68.

Kraaimaat FW. Personal communication January 81999.

Kraaimaat FW, Brons MR, Geenen R, Bijlsma JWJ. The effect of cognitive behavior therapy in patients with rheumatoid arthritis. Behaviour Research \& Therapy 1995 Jun;33(5):487-95.

Huiskes 1991-B \{published data only\}

Huiskes 1991-C \{published data only\}

Kaplan 1981 \{published data only\}

Kaplan S, Kozin F. A controlled study of group counseling in rheumatoid arthritis. Journal of Rheumatology 1981;8(1):91-9.

\section{Leibing 1999 \{published data only\}}

* Leibing E, Pfingsten M, Bartmann U, Rueger U, Schuessler G.

Cognitive-behavioral treatment in unselected rheumatoid arthritis outpatients. Clinical Journal of Pain 1999;15:58-66.

Lindroth 1997 \{published and unpublished data\}

Lindroth Y. Personal communication January 1999.

* Lindroth Y, Brattstrom M, Bellman I, Ekestaf G, Olofsson Y, Strombeck B, Stenshed B, Wikstrom I, Nillson JA, Wollheim FA. A problem-based education program for patients with rheumatoid arthritis: evaluation after three and twelve months. Arthritis Care \& Research 1997;10(5):325-32.

\section{Lorig 1985 \{published data only\}}

Lorig K. Personal communication Glasgow, June 81999.

* Lorig K, Lubeck D, Kraines R, Seleznick M, Holman HR.

Outcomes of self-help education for patients with arthritis.

Arthritis \& Rheumatism 1985;28(6):680-5.

Lorig 1986 \{published data only\}

Lorig K. Personal communication Glasgow, June 81999.

* Lorig K, Feigenbaum P, Regan C, Ung E, Chastain RL, Holman HR. A comparison of lay-taught and professional-taught arthritis self-management courses. Journal of Rheumatology 1986;13(4): $763-7$.

Lorig 1986-B \{published data only\}

Lorig 1989 \{published data only\}

Lorig K. Personal communication Glasgow, June 81999.

* Lorig K, Seleznick M, Lubeck D, Ung E, Chastain RL, Holman

HR. The beneficial outcomes of the arthritis self-management course are not adequately explained by behavior change. Arthritis \& Rheumatism 1989;32(1):91-5.

Lorig 1999a \{published data only\}

* Lorig KR, Sobel DS, Stewart AL, Brown BW Jr, Bandura A, Ritter P, Gonzalez VM, Laurent DD, Holman HR. Evidence suggesting that a chronic disease self-management program can improve health status while reducing hospitalization. Medical Care 1999;37:5-14.

Lorig 1999b \{published data only\}

* Lorig K, Gonzalez VM, Ritter P. Community-based Spanish language arthritis education program: a randomized trial. Medical Care 1999;37:957-63.

Maggs 1996 \{published data only\}

Maggs FM, Jubb RW, Kemm JR. Single-blind randomized controlled trial of an educational booklet for patients with chronic arthritis. British Journal of Rheumatology 1996;35(8):775-7.

Maggs 1996-B \{published data only\}
Maisiak 1996a \{published data only\}

Maisiak R. Personal communication November 271999.

* Maisiak R, Austin JS, West SG, Heck L. The effect of personcentered counseling on the psychological status of persons with systemic lupus erythematosus or rheumatoid arthritis: a randomized, controlled trial. Arthritis Care \& Research 1996;9(1): 60-6.

Maisiak 1996b \{published and unpublished data\}

Maisiak R. Personal communication January 201999.

* Maisiak R, Austin J, Heck L. Health outcomes of two telephone interventions for patients with rheumatoid arthritis or osteoarthritis. Arthritis \& Rheumatism 1996;39(8):1391-9.

\section{Maisiak 1996b-B \{published data only\}}

McEvoy-DeVellis 1988 \{published data only\}

McEvoy-DeVellis B. Personal communication December 11, 1999. * McEvoy-DeVellis B, Blalock SJ, Hahn PM, DeVellis RF, Hochbaum GM. Evaluation of a problem-solving intervention for patients with arthritis. Patient Education and Counseling 1988;11: $29-42$.

Neuberger 1993 \{published data only\}

Neuberger GB, Smith KV, Black SO, Hassasein R. Promoting selfcare in clients with arthritis. Arthritis Care \& Research 1993;6(3): 141-8.

Neuberger 1993-B \{published data only\}

Neuberger 1993-C \{published data only\}

O'Leary 1988 \{published data only\}

O'Leary A, Shoor S, Lorig K, Holman HR. A cognitive-behavioral treatment for rheumatoid arthritis. Health Psychology 1988;7(6): $527-44$.

Oermann 1986 \{published data only\}

Oermann MH. Personal communication January 9, 1999.

* Oermann MH, Doyle TH, Clark LR, Rivers CL, Rose VY. Effectiveness of self-instruction for arthritis patient education. Patient Education and Counseling 1986;8:245-54.

Parker 1984 \{published data only\}

* Parker JC, Singsen BH, Hewett JE, Walker SE, Hazelwood SE, Hall PJ, Holsten DJ, Rodon CM. Educating patients with rheumatoid arthritis: a prospective analysis. Archives of Physical Medicine and Rehabilitation 1984;65(12):771-4.

Smarr KL. Personal communication March 231999.

Parker 1988 \{published data only\}

Hewett J. Personal communication March 172000.

* Parker JC, Frank RG, Beck NC, Smarr KL, Buescher KL, Phillips LR, Smith EI, Anderson SK, Walker SE. Pain management in rheumatoid arthritis patients. A cognitive-behavioral approach. Arthritis \& Rheumatism 1988;31(5):593-601.

Parker 1988-B \{published data only\}

Parker 1995 \{published data only\}

* Parker JC, Smarr KL, Buckelew SP, Stucky-Ropp RC, Hewett JE, Johnson JC, Wright GE, Irvin WS, Walker SE. Effects of stress management on clinical outcomes in rheumatoid arthritis. Arthritis \& Rheumatism 1995;38(12):1807-18.

Smarr KL. Personal communication January 122000.

Parker 1995-B \{published data only\} 
Radojevic 1992 \{published data only\}

Radojevic V, Nicassio PM, Weisman MH. Behavioral intervention with and without family support for rheumatoid arthritis. Behavior Therapy 1992;23:13-30.

Radojevic 1992-B \{published data only\}

Radojevic 1992-C \{published data only\}

Rhodes 1988 \{published data only\}

Rhodes JT, Foard T, Dickstein L. Professional peer counseling in the management of rheumatoid arthritis: A clinical trial. In: Ahmed PI editor(s). Coping with arthritis. Springfield IL. USA: Ch. C. Thomas Publ, 1988:73-106.

Riemsma 1999 \{unpublished data only\} Riemsma RP. Personal communication January 1999.

Riemsma 1999-B \{unpublished data only\}

Rodriguez 1996 \{published data only\}

* Rodriguez-Lozano C, Bilbao A, Naranjo A, Ojeda S, Francisco F. Patient education in rheumatoid arthritis: its influence in the disease outcome [Educacion del paciente con artritis reumatoide: su influencia en la evolucion de la enfermedad]. Revista Espanola Reumatologia 1996;23:40-48.

Savelkoul 2001 \{published and unpublished data\} * Savelkoul M. Personal communication April 112000. Savelkoul M, De Witte LP, Van der Borne BHW, Van der Tempel $\mathrm{H}$. Effects of a coping intervention on patients with rheumatic diseases: Results of a randomized controlled trial. Arthritis \& Rheumatism 2001;45(1):69-76.

Savelkoul 2001-B \{published and unpublished data\}

\section{Scholten 1999 \{published data only\}} Christine Scholten. Personal communication Vienna, 25 April 2002.

* Scholten C, Brodowicz T, Graninger W, Gardavsky I, Pils K, Pesau B, Eggl-Tyl E, Wanivenhaus A, Zielinski CC. Persistent functional and social benefit 5 years after a multidisciplinary arthritis training program. Archives of Physical Medicine \& Rehabilitation 1999;80:1282-7.

Sharpe 2001 \{published data only\}

Louise Sharpe. Personal communication Sydney, 19 March 2002. Sharpe L, Sensky T, Timberlake N, Ryan B, Allard S. Long-term efficacy of a cognitive behavioural treatment for patients recently diagnosed with rheumatoid arthritis. Rheumatology 2002 (Submitted).

* Sharpe L, Sensky T, Timberlake N, Ryan B, Brewin CR, Allard S. A blind, randomized, controlled trial of cognitive-behavioural intervention for patients with recent onset rheumatoid arthritis: Preventing psychological and physical morbidity. Pain 2001;89: $275-83$.

\section{Shearn 1985 \{published data only\}}

Shearn MA, Fireman BH. Stress management and mutual support groups in rheumatoid arthritis. American Journal of Medicine 1985; 78(5):771-5.

Shearn 1985-B \{published data only\}
Stenstrom 1994 \{published and unpublished data\}

Stenstrom CH. Personal communication December 291998.

* Stenstrom CH. Home exercise in rheumatoid arthritis functional class II: goal setting versus pain attention. Journal of Rheumatology 1994;21(4):627-34.

Strauss 1986 \{published data only\}

Strauss GD, Spiegel JS, Daniels M, Spiegel T, Landsverk J, RoyByrne P, Edelstein C, Ehlhardt J, Falke R, Hindin L, Zackler L. Group therapies for rheumatoid arthritis. A controlled study of two approaches. Arthritis \& Rheumatism 1986;29(10):1203-9.

\section{Strauss 1986-B \{published data only\}}

Taal 1993 \{published and unpublished data\}

Taal E. Personal communication December 1998.

Taal E, Riemsma RP, Brus HLM, Seydel ER, Rasker JJ, Wiegman

O. Group education for patients with rheumatoid arthritis. Patient Education and Counseling 1993;20(2-3):177-87.

* Taal E, Seydel ER, Riemsma RP, Brus HLM, Rasker JJ, Wiegman O. Omgaan met Reumatoide Arthritis: Ontwikkeling en evaluatie van een groepsprogramma voor patienten met reumatoide artritis. Enschede, The Netherlands: Universiteit Twente (Aspekt 35), 1992.

Wetstone 1985 \{published data only\}

Wetstone SL, Sheenan TJ, Votaw R, Peterson MG, Rothfield N. Evaluation of a computer based education lesson for patients with rheumatoid arthritis. Journal of Rheumatology 1985;12(5):907-12.

\section{References to studies excluded from this review}

Darmawan 1992 \{published data only\} Darmawan J, Muirden KD, Wigley RD, Valkenburg HA. Arthritis community education by leather puppet (wayang kulit) shadow play in rural Indonesia (Java). Rheumatology International 1992;12 (3):97-101.

Feinberg 1992 \{published data only\}

Feinberg J. Effect of the arthritis health professional on compliance with use of resting hand splints by patients with rheumatoid arthritis. Arthritis Care \& Research 1992;5(1):17-23.

Linne 2001 \{published data only\}

Linne AL, Lennart HJ. The effects on knowledge of the systematic education of patients with joint diseases treated with NSAIDs and diuretics. Patient Education and Counseling 2001;42:165-74.

Pope 1998 \{published data only\}

Pope J, Stevens A, Rooks M. A randomized double blind trial of verbal NSAID education compared to verbal and written education. Journal of Rheumatology 1998;25(4):771-5.

Sebro 1993 \{published data only\} Sebro B, Dubravica M, Jajicz. Spontaneous use of active and passive coping strategies for pain in patients with rheumatoid arthritis. Reumatizam 1993;40(1):1-4.

Van Deussen 1987 \{published data only\}

Van Deusen J, Harlowe D. The efficacy of the ROM Dance Program for adults with rheumatoid arthritis. American Journal of Occupational Therapy 1987;41(2):90-5.

Young 1995 \{published data only\} Young LD, Bradley LA, Turner RA. Decreases in health care resource utilization in patients with rheumatoid arthritis following 
a cognitive behavioral intervention. Biofeedback Self Regul 1995;20 (3):259-68.

\section{References to studies awaiting assessment}

Newman 2001 \{published data only\}

Newman AM. Self-help care in older African Americans with arthritis. Geriatric Nursing 2001;22:135-8.

\section{Additional references}

\section{ARA 1982}

American Rheumatism Association. Dictionary of the Rheumatic Diseases. New York: on behalf of American College of Rheumatology, 1982.

\section{Arroll 1998}

Arroll B, Kenealy T. Antibiotics versus placebo in the common cold. Cochrane Database of Systematic Reviews 1998, Issue 4.

\section{Basler 1993}

Basler HD. Group treatment for pain and discomfort. Patient Education and Counseling 1993;20(2-3):167-75.

\section{Beck 1961}

Beck AT, Wall CH, Mendelson M, Mock J, Erbraugh J. An inventory for measuring depression. Archives of General Psychiatry 1961;4:53-63.

\section{Bradley 1994}

Bradley LA. Behavioral interventions for managing chronic pain. Bulletin on the Rheumatic Diseases 1994;43(2):2-5. Review.

\section{Brooks 2001}

Brooks P, Hochberg M. Outcome measures and classification criteria for the rheumatic diseases. A compilation of data from OMERACT (Outcome Measures for Arthritis Clinical Trials), ILAR (International League of Associations for Rheumatology), regional leagues and other groups. Rheumatology 2001;40(8): 896-906.

\section{CCSG 1978}

The Canadian Cooperative Study Group (SSCG). The Canadian trial of aspirin and sulfinpyrazone in threatened stroke. New England Journal of Medicine 1978;299:53-9.

\section{Chamber 1982}

Chamber LW, McDonald LA, Tugwell P, Buchanan WW, Kraag GR. The McMaster Health Index Questionnaire as a measure of quality of life for patients with rheumatoid disease. Journal of Rheumatology 1982;9:780-4.

\section{Clarke 2000}

Clarke M, Oxman AD (Ed.). Cochrane Reviewers Handbook 4.0 [updated July 1999]. Vol. issue 1, Oxford: Update Software, 2000.

Colditz 1989

Colditz GA, Miller JN, Mosteller F, Colditz GA, Miller JN, Mosteller F. How study design affects outcomes in comparisons of therapy. I: medical. Statistics in Medicine 1989;8:441-54.

\section{Criswell 2001}

Criswell LA, Saag KG, Sems KM, Welch V, Shea B, Wells G, Suarez-Almazor ME. Moderate-term, low-dose corticosteroids for rheumatoid arthritis. Cochrane Database of Systematic Reviews 2001, Issue 3. [DOI: 10.1002/14651858.CD001158]

\section{DeVellis 1993}

DeVellis RF, Blalock SJ. Psychological and educational interventions to reduce arthritis disability. Baillieres Clinical Rheumatology 1993;7(2):397-416. Review.

\section{Felson 1992}

Felson DT. Bias in meta-analytic research. Journal of Clinical Epidemiology 1992;45:885-92.

\section{Fries 1980}

Fries JF, Spitz P, Kraines FG, Holman HR. Measurement of patient outcome in arthritis. Arthritis and Rheumatism 1980;23:137-45.

Furst 1987

Furst GP, Gerber LH, Smith CC, Fisher S, Shulman B. A program for improving energy conservation behaviors in adults with rheumatoid arthritis. American Journal of Occupational Therapy 1987;41(2):102-11.

\section{Gerber 1987}

Gerber L, Furst G, Shulman B, Smith C, Thornton B, Liang M, Cullen K, Stevens MB, Gilbert N. Patient education program to teach energy conservation behaviors to patients with rheumatoid arthritis: a pilot study. Archives of Physical Medicine and Rehabilitation 1987;68(7):442-5.

\section{Gibson 2001}

Gibson PG, Coughlan J, Wilson AJ, Hensley MJ, Abramson M, Bauman A, Walters EH. Limited (information only) patient education programs for adults with asthma. Cochrane Database of Systematic Reviews 2001, Issue 3. [DOI: 10.1002/ 14651858.CD001005]

Glazier 1996

Glazier R. Managing early presentation of rheumatoid arthritis. Systematic overview. Canadian Family Physician 1996;42:913-22. Review.

\section{Goeppinger 1997}

Goeppinger J, Lorig K. Interventions to reduce the impact of chronic disease: community-based arthritis patient education. Annual Review of Nursing Research 1997;15:101-22. Review.

\section{Hawley 1995}

Hawley DJ. Psycho-educational interventions in the treatment of arthritis. Bailliere's Clinical Rheumatology 1995;9:803-23. Review.

\section{Hill 1995}

Hill J. Patient education in rheumatic disease. Nursing Standard 1995;9(25):25-8. Review.

\section{Hirano 1994}

Hirano PC, Laurent DD, Lorig K. Arthritis patient-education studies, 1987-1991: a review of the literature. Patient Education and Counseling 1994;24:9-54. Review.

\section{Holloway 2001}

Holloway E, Ram FSF. Breathing exercises for asthma. Cochrane Database of Systematic Reviews 2001, Issue 3. [DOI: 10.1002/ 14651858.CD001277.pub2]

\section{Jadad 1996}

Jadad AR, Moore A, Carroll D, Jenkinson C, Reynolds DJM, Gavaghan DJ, McQuay HJ. Assessing the quality of reports of randomized clinical trials: Is blinding necessary?. Controlled Clinical Trials 1996;17:1-12. 


\section{Karjalainen 2001a}

Karjalainen K, Malmivaara A, van Tulder M, Roine R, Jauhiainen M, Hurri H, Koes B. Biopsychosocial rehabilitation for upper limb repetitive strain injuries in working age adults. Cochrane Database of Systematic Reviews 2001, Issue 3. [DOI: 10.1002/ 14651858.CD002269]

Karjalainen 2001b

Karjalainen K, Malmivaara A, van Tulder M, Roine R, Jauhiainen M, Hurri H, Koes B. Multidisciplinary biopsychosocial rehabilitation for subacute low back pain among working age adults. Cochrane Database of Systematic Reviews 2001, Issue 3. [DOI: 10.1002/14651858.CD002193]

\section{Karlowski 1975}

Karlowski TR, Chalmers TC, Frenkel LD, Kapikian AZ, Lewis TL, Lynch JM. Ascorbic acid for the common cold: a prophylactic and therapeutic trial. JAMA 1975;231:1038-42.

\section{Keefe 1997}

Keefe FJ, Caldwell DS. Cognitive behavioral control of arthritis pain. Medical Clinics of North America 1997;81(1):277-90. Review.

\section{Kirwan 1990}

Kirwan JR. Patient education in rheumatoid arthritis. Current Opinion in Rheumatology 1990;2:336-9.

\section{Kunz 1998}

Kunz R, Oxman AD Ku. Kunz R, Oxman AD. The unpredictability paradox: review of empirical comparisons of randomised and non-randomised clinical trials. BMJ 1998;317: $1185-90$.

\section{Lancaster 2001}

Lancaster T, Stead LF. Self-help interventions for smoking cessation. Cochrane Database of Systematic Reviews 2001, Issue 3. [DOI: 10.1002/14651858.CD001118.pub2]

\section{Langer 1990}

Langer HE, Mattussek S. Patient education in rheumatology [Patientenschulung in der Rheumatologie]. Wien Med Wochenschr 1990;140(12):349-51. Review..

\section{Lindroth 1989}

Lindroth Y, Bauman A, Barnes C, McCredie M, Brooks PM. A controlled evaluation of arthritis education. British Journal of Rheumatology 1989;28(1):7-12.

\section{Lorig 1987}

Lorig K, Konkol L, Gonzalez V. Arthritis patient Education: A review of the literature. Patient Education and Counseling 1987;10 207-52. Review.

\section{Lorig 1992}

Lorig K. Common sense patient education. Ivanhoe, Victoria, Australia: Fraser Publications, 1992.

\section{Mazzuca 1982}

Mazucca SA. Does patient education in chronic disease have therapeutic value?. Journal of Chronic Diseases 1982;35:521-9.

\section{Meenan 1980}

Meenan RF, Gertman PM, Mason JH. Measuring health status in arthritis. The arthritis impact measurement scales. Arthritis and Rheumatism 1980;23(2):146-52.

\section{Meenan 1992}

Meenan RF, Mason JH Anderson JJ, Guccione AA, Kazis LE. AIMS2: the content and properties of a revised and expanded Arthritis Impact Measurement Scales health status questionnaire. Arthritis and Rheumatism 1992;35:1-10.

\section{Mullen 1987}

Mullen PD, Laville EA, Biddle AK, Lorig K. Efficacy of psychoeducational interventions on pain, depression, and disability in people with arthritis: a meta-analysis. Journal of Rheumatology 1987;14(Suppl 15):33-9. Review.

\section{Pincus 1989}

Pincus T, Callahan L, F, Brooks RH, Fuchs HA, Olsen NJ, Kaye JJ. Self-report questionnaire scores in rheumatoid arthritis compared with traditional physical, radiographic, and laboratory measures. Annals of Internal Medicine 1989;110:259-66.

\section{Radloff 1977}

Radloff LS. The CES-D scale: A self-report depression scale for research in general populations. Applied Psychological Measurement 1977;1:385-401.

\section{Ritchie 1968}

Ritchie DM, Boyle JA, McInnes JM, Jasani MK, Dalakos TG, Grieveson P, et al.Clinical studies with an articular index for the assessment of joint tenderness in patients with rheumatoid arthritis.. Quarterly Journal of Medicine 1968;147:393-406.

\section{Sackett 1979}

Sackett DL. Bias in analytic research. Journal of Chronic Diseases 1979;32:51-63.

\section{Schulz 1995}

Schulz KF, Chalmers I, Hayes RJ, Altman DG. Empirical evidence of bias: dimensions of methodological quality associated with estimates of treatment effects in controlled trials. JAMA 1995;273: 408-12.

\section{Suarez-Almazor 2001a}

Suarez-Almazor ME, Belseck E, Shea B, Homik J, Wells G, Tugwell P. Antimalarials for treating rheumatoid arthritis. Cochrane Database of Systematic Reviews 2001, Issue 3. [DOI: 10.1002/ 14651858.CD000959]

Suarez-Almazor 2001b Suarez-Almazor ME, Spooner CH, Belseck E, Shea B. Auranofin versus placebo in rheumatoid arthritis. Cochrane Database of Systematic Reviews 2001, Issue 3. [DOI: 10.1002/ 14651858.CD002048]

\section{Suarez-Almazor 2001c}

Suarez-Almazor ME, Spooner C, Belseck E. Penicillamine for treating rheumatoid arthritis. Cochrane Database of Systematic Reviews 2001, Issue 3. [DOI: 10.1002/14651858.CD001460]

Suarez-Almazor 2001d

Suarez-Almazor ME, Spooner C, Belseck E. Azathioprine for treating rheumatoid arthritis. Cochrane Database of Systematic Reviews 2001, Issue 3. [DOI: 10.1002/14651858.CD001461]

\section{Suarez-Almazor 2001e}

Suarez-Almazor ME, Belseck E, Shea B, Wells G, Tugwell P. Methotrexate for treating rheumatoid arthritis. Cochrane Database of Systematic Reviews 2001, Issue 3. [DOI: 10.1002/ 14651858.CD000957] 
Superio 1996

Superio-Cabuslay E, Ward MM, Lorig KR. Patient education interventions in Osteoarthritis and Rheumatoid Arthritis: A metaanalytic comparison with non-steroidal antiinflammatory drug treatment. Arthritis Care and Research 1996;9:292-301. Review.

\section{Taal 1996}

Taal E, Rasker JJ, Wiegman O. Patient education and self-

management in the rheumatic diseases: A self-efficacy approach. Arthritis Care and Research 1996;9:229-38.

\section{Taal 1997}

Taal E, Rasker JJ, Wiegman O. Group education for rheumatoid arthritis patients. Seminars in Arthritis and Rheumatism 1997;26(6): 805-16. Review.

\section{Thompson 1987}

Thompson PW. Laboratory markers of joint inflammation and damage. British Journal of Rheumatology 1987;26:83-5.

\section{Tucker 1991}

Tucker M, Kirwan JR. Does patient education in rheumatoid arthritis have therapeutic potential?Annals of the Rheumatic Diseases 1991; 50: 422-428. Annals of the Rheumatic Diseases 1991; 50:422-8.

\section{Tugwell 1993}

Tugwell P, Boers M, for the OMERACT Committee. Developing consensus on preliminary core efficacy endpoints for Rheumatoid Arthritis clinical trials. The Journal of Rheumatology 1993;20(3): $555-556$.

\section{van Tulder MW 2001}

van Tulder MW, Ostelo RWJG, Vlaeyen JWS, Linton SJ, Morley SJ, Assendelft WJJ. Behavioural treatment for chronic low back pain. Cochrane Database of Systematic Reviews 2001, Issue 3. [DOI: 10.1002/14651858.CD002014.pub2]

\section{Weissman 1977}

Weissman MM, Sholomskas D, Pottengor M, Prusoff BA, Locke BZ. Assessing depressive symptoms in five psychiatric populations: a validation study. American Journal of Epidemiology 1977;106: 203-14.

\section{Wells 2001}

Wells G, Haguenauer D, Shea B, Suarez-Almazor ME, Welch VA, Tugwell P. Cyclosporine for treating rheumatoid arthritis. Cochrane Database of Systematic Reviews 2001, Issue 3. [DOI: 10.1002/ 14651858.CD001083]

\section{Ytterberg 1994}

Ytterberg SR, Mahowald ML, Krug HE. Exercise for arthritis. Baillieres Clinical Rheumatology 1994;8(1):161-89. Review.

\section{Zigmond 1983}

Zigmond AS, Snaith RP. The Hospital Anxiety and Depression Scale. Acta Psychiatrica Scandinavica 1983;67:361-70.

\section{Zung 1964}

Zung WWK. A self-rating depression scale. Archives of General Psychiatry 1964;12:63-70.

* Indicates the major publication for the study 


\section{CHARACTERISTICS OF STUDIES}

\section{Characteristics of included studies [ordered by study ID]}

\section{Appelbaum 1988}

\begin{tabular}{ll} 
Methods & $\begin{array}{l}\text { A } 10 \text { weeks, cross-over study. } \\
\text { Assessments were done at baseline and after } 10 \text { weeks. } \\
\text { Quality: 0/0/0/0 }\end{array}$ \\
\hline Participants & $\begin{array}{l}\text { 19 RA patients recruited, } 1 \text { drop-out before baseline assessment, } 18 \text { randomised (9/9) and analysed. Inclusion: } \\
\text { outpatients with functional class Stage } 2 \text { or } 3 \text { RA according to the ARA-criteria. Mean age: } 62.2 \text { yr, } 11 \% \text { female, } \\
33 \% \text { functional class } 2 .\end{array}$ \\
\hline Interventions & $\begin{array}{l}\text { Active treatment: } 10 \text { sessions in } 6 \text { weeks, including: progressive relaxation training and thermal biofeedback (10 trials } \\
\text { each) and instruction in cognitive pain management strategies. } \\
\text { Controls: symptom monitoring. }\end{array}$ \\
\hline Outcomes & $\begin{array}{l}\text { Included: McGill Pain Questionnaire, Daily Activities Questionnaire (personal hygiene, dressing, eating, household, } \\
\text { communication). } \\
\text { Not reported: Beck Depression Inventory, State-Trait Anxiety Inventory. } \\
\text { Others: Weekly Arthritis Diary (weekly pain index, weekly peak pain index), MMPI. }\end{array}$ \\
\hline Notes & $\begin{array}{l}\text { ARA }=\text { American Rheumatism Association } \\
\text { MMPI = Minnesota Multiphasic Personality Inventory }\end{array}$ \\
\hline
\end{tabular}

\section{Balmer 1989}

\begin{tabular}{ll} 
Methods & $\begin{array}{l}\text { A } 6 \text { months counselling intervention. } \\
\text { Assessments were done at baseline and after } 6 \text { months. } \\
\text { Quality: 0/0/1/0 }\end{array}$ \\
\hline Participants & $\begin{array}{l}\text { 30 RA-patients randomised (20 couns/10 contr) } 1 \text { drop-out (couns) before start of sessions. No inclusion criteria } \\
\text { mentioned. Mean age: } 56 \text { yr, } 73 \% \text { female. }\end{array}$ \\
\hline Interventions & $\begin{array}{l}\text { Counselling: } 2 \text { groups }(10 \text { persons) received weekly }(1 \text { hr) counselling sessions over } 6 \text { months by different counselors. } \\
\text { Controls: no-intervention }\end{array}$ \\
\hline Outcomes & $\begin{array}{l}\text { Included: None. } \\
\text { Not reported: McGill Pain Questionnaire, VAS-pain, AIMS, Ritchie Articular Index, Beck Depression Inventory, } \\
\text { ESR. } \\
\text { Others: Arthritis Helplessness Index, Multidimensional Health Locus of Control. }\end{array}$ \\
\hline Notes & $\begin{array}{l}\text { VAS }=\text { Visual Analogue Scale } \\
\text { AIMS }=\text { Arthritis Impact Measurement Scale } \\
\text { ESR }=\text { Erythrocyte Sedimentation Rate }\end{array}$ \\
\hline
\end{tabular}


Barlow 1997

\begin{tabular}{ll} 
Methods & $\begin{array}{l}\text { A 3 weeks, cross-over design. } \\
\text { Assessments were done at baseline, after } 3 \text { weeks and after } 6 \text { months. } \\
\text { Quality: 0/0/0/0 }\end{array}$ \\
\hline Participants & $\begin{array}{l}\text { Consecutive patients with definite RA were asked to participate, } 142 \text { agreed, } 34 \text { were lost to follow-up (no reasons } \\
\text { stated), } 108 \text { RA-patients were used for T1-T2 analysis. Mean age was } 59.3 \text { yr and } 81 \% \text { were female. }\end{array}$ \\
\hline Interventions & $\begin{array}{l}\text { Experimental group: Mailed RA-leaflets from the ARC, to be read at home during a three week period. } \\
\text { Control group: no intervention. }\end{array}$ \\
\hline Outcomes & $\begin{array}{l}\text { Included: VAS-pain, HADS (Anxiety and Depression). } \\
\text { Others: HAQ (only at baseline), VAS-fatigue, ASE (pain and other symptoms). }\end{array}$ \\
\hline Notes & $\begin{array}{l}\text { ARC }=\text { Arthritis and Rheumatism Council (UK) } \\
\text { VAS }=\text { Visual Analogue Scale } \\
\text { HADS }=\text { Hospital Anxiety and Depression Scale } \\
\text { HAQ }=\text { Health Assessment Questionnaire } \\
\text { ASE }=\text { Arthritis Self-Efficacy }\end{array}$ \\
\hline
\end{tabular}

\section{Barlow 2000}

Methods A pragmatic randomised controlled study. Assessments were done at baseline and 4 months follow-up. The intervention group completed a 12-month follow-up.

Quality: 2/0/2/1

Participants 602 people with arthritis recruited (I: 344; C: 258).

58 were ineligible or non-consenting (I: 33 ; C: 25 ).

544 people were consenting and returned baseline questionnaires (I: 311; C: 233; RA-patients: I: 115 (37\%); C: 77 $(33 \%))$.

423 returned the 4 month follow-up (I: 234; C: 189 ).

602 (I: 344; C: 258) randomised.

544 analysed at 4 months (I:311; C: 233). At 4 months follow-up 423 (I: 234; C: 189) respondents remaining, intention-to-treat analyses with corresponding baseline value replacing missing values at both follow-ups.

Course attendance was not dependent on participation in the evaluation. Entry criteria were: age 18 or older; ability to complete the questionnaire and a diagnosis of arthritis from the participant's GP.

Mean age for all respondents at baseline ( $\mathrm{n}=544)$ : $58.1 \mathrm{y}$ (SD: 12.8$)$, 84\% female. Type of arthritis: $35 \% \mathrm{RA}, 52 \%$

OA, $13 \%$ other. Disease duration for all respondents at baseline ( $n=544)$ : Mean: 11.0y (SD: 11.1). Comorbidities for all respondents at baseline ( $n=544): 56 \%$.

The ASMP comprises 6 weekly sessions, each lasting approximately $2 \mathrm{~h}$, delivered by pairs of lay leaders, most of whom have arthritis themselves. Leaders are trained by Arthritis Care and course delivery is guided by a manual to ensure consistency of content. The ASMP is multi-component and topics include: information about arthritis, an overview of self-management principles, exercise, cognitive symptom management (e.g. distraction, visualization and guided imagery), dealing with depression, nutrition, communication with family and health professionals, and contracting. The last of these involves the setting of realistic goals to be achieved during the forthcoming week. Participants report back to their group on their achievements at the next weekly session. Participants are given a copy of the Arthritis Helpbook (Lorig and Fries, 1995), which is an accompanying guide to the course. The format of the ASMP is largely interactive, with short 'lecturettes' to introduce topics, group discussion, problem solving, role plays 
Barlow 2000 (Continued)

and mastery experience (i.e. trying out the skills introduced on the ASMP).

Controls: a 4 months waiting list control group.

Outcomes Included: VAS-pain, health status (Modified Health assessment Questionnaire (M-HAQ), Hospital Anxiety and Depression Scale (HADS) and a subsample completed the EuroQol (EQ-5D).

Others: Arthritis self-efficacy, health behaviours (exercise, cognitive symptom management, diet and relaxation)and VAS-fatigue, and the Positive and Negative Affect Scales (PANAS).

Notes $\quad$ ASMP $=$ Arthritis Self-Management Programme.

VAS = Visual Analogue Scale

\section{Bell 1998}

\begin{tabular}{ll} 
Methods & $\begin{array}{l}\text { A } 6 \text { week, outcome assessor blinded, cross-over study, no co-interventions allowed. } \\
\text { Assessments were done at baseline and after } 6 \text { weeks. } \\
\text { Quality: 2/2/2/1 }\end{array}$ \\
\hline Participants & $\begin{array}{l}\text { 150 RA patients randomised (76 EG/74 CG), } 23 \text { drop-outs (7/16), leaving } 127 \text { (69/59) for analysis. Inclusion: RA } \\
\text { according to ARA-criteria; referral for PT (first to CTS); disease onset after } 18 \text { yr; ability to read, write, speak English; } \\
\text { understand purpose of study and informed consent; requires > } 3 \text { visits or }>2 \text { h of PT; available for follow-up; at least } \\
\text { 3of } 12 \text { improvement areas, } 6 \text { tender and painful joints, } 45 \text { min morning stiffness; functional class } 2 \text { or } 3 . \text { Exclusion: } \\
\text { involvement in pilot study, require urgent care; current or past participatation in similar programme. }\end{array}$
\end{tabular}

Interventions EG: 4 visits (3h) of physical therapy over 6 weeks, including: total evaluation of disease activity, and level of function; review of 5 brochures, RA disease management, medications, nutrition and exercise and access to community resources and individual goal setting.

CG: Waiting list controls (after 6 weeks)

\begin{tabular}{ll}
\hline Outcomes & $\begin{array}{l}\text { Included: VAS-pain, tender joint count. } \\
\text { Others: Stanford Arthritis Self-Efficacy Scales. }\end{array}$ \\
\hline Notes & $\begin{array}{l}\text { ARA }=\text { American Rheumatism Association } \\
\text { PT }=\text { Physical Therapy } \\
\text { CTS }=\text { Consultation and Therapy Service } \\
\text { VAS }=\text { Visual Analogue Scale }\end{array}$ \\
\end{tabular}

\section{Bradley 1987}

\begin{tabular}{ll} 
Methods & $\begin{array}{l}\text { A study of } 15 \text { sessions of Cognitive Behavioural group therapy compared to } 15 \text { sessions of structured group social } \\
\text { support therapy with a no adjunct treatment control group. } \\
\text { Assessments were done at baseline, immediately after the intervention, and } 1 \text { year after the intervention. } \\
\text { Quality: 0/0/1/2 }\end{array}$ \\
\hline Participants & $\begin{array}{l}\text { 68 RA patients randomised, } 2 \text { drop-outs before first assessment, } 11 \text { (6 CBT/3 SGT/2 NAT) before treatment and } \\
2(0 / 1 / 1) \text { during treatment. } 53 \text { analysed (17/18/18), } 5 \text { patients (1/1/3) excluded because of incomplete data at } 1 \mathrm{yr} \\
\text { follow-up. Inclusion: definite or classis RA according to the } 1987 \text { ARA criteria. Mean age: } 50.09 \text { (SD: } 12.44) ; 81 \% \\
\text { female; } 9 \% \text { functional class } 1,53 \% \text { class } 2,38 \% \text { classs } 3 .\end{array}$
\end{tabular}




\section{Bradley 1987 (Continued)}

\begin{tabular}{ll} 
Interventions & $\begin{array}{l}\text { CBT: Biofeedback assisted cognitive behavioural group therapy: } 5 \text { sessions of individual thermal biofeedback training } \\
\text { to promote increased skin temperature at most painful joints and } 10 \text { small group meetings (with family and friends) } \\
\text { including education, relaxation training and instruction in behavioural goalsetting and use of self-rewards. } \\
\text { NAT: no adjunct treatment control group }\end{array}$ \\
\hline Outcomes & $\begin{array}{l}\text { Included: None. } \\
\text { Not reported: VAS-pain (unpleasentness and intensity), M-HAQ, tender joints count, patient's rating of disaese } \\
\text { activity, physician's rating of disease activity, STAI-Trate Form; Depression Adjective Scale, ESR. } \\
\text { Others: Health Locus-of-control Scale; Arthritis Helplessness Index. }\end{array}$ \\
\hline Notes & $\begin{array}{l}\text { ARA }=\text { American Rheumatology Association. } \\
\text { VAS }=\text { Visual Analogue Scale } \\
\text { M-HAQ = Modified Health Assessment Questionnaire } \\
\text { STAI }=\text { State-Trate Anxiety Inventory } \\
\text { ESR }=\text { Erythrocyte sedimentation rate }\end{array}$ \\
\hline
\end{tabular}

\section{Bradley 1987-B}

\begin{tabular}{l|l} 
Methods & \\
\hline Participants & \\
\hline $\begin{array}{l}\text { Interventions } \\
\text { SGT: structured group social support therapy: } 15 \text { sessions of structured social support in small group meetings (with } \\
\text { family and friends), including education, discuusion of present coping strategies and encouragement to develop } \\
\text { improved coping methods. }\end{array}$ \\
\hline NAT: no adjunct treatment control group \\
\hline Notes & \\
\hline
\end{tabular}

\section{Branch 1999}

Methods An 8-week randomised controlled trial with an intervention by a arthritis patient educator as well as standard rheumatologic care compared with standard rheumatologic care.

Assessments were done at baseline and 8 weeks later.

Quality: 0/0/0/0

Participants 537 patients were randomised. The authors state: "Of the 537 patients randomised to enter this study, 108 had their referral diagnosis confirmed by a rheumatologist, had sufficient time to complete the initial questionnaires, and were enrolled in the study." 58 (I: 27; C: 31) analysed. Probably all 537 patients recruited were randomised, 429 of these dropped-out at baseline assessment. Intervention group: 20 patients (43\%) did not complete the entire protocol. Controls: 30 patients (49\%) did not complete the entire protocol. Inclusion: All newly referred (August-December 1994) arthritis patients to the clinic, meeting the ACR criteria for rheumatoid arthritis, osteoarthritis, or fybromyalgia and were not excluded on the basis of length of disease or because of current use of medication. Exclusion criteria regarding 'length of disease' or 'current use of medication' not specified. Mean age and percentage female: not stated. 


\section{Branch 1999 (Continued)}

Interventions $\begin{aligned} & \text { Intervention: A 10-30 minutes face-to-face interaction with an arthritis patient educator during a routine clinic visit. } \\ & \text { During the encounter, the arthritis patient educator utilised a standard protocol as a guide to ascertain the diagnosis } \\ & \text { of the patient, if known, as well as whether the patient had specific concerns about his or her condition. The arthritis } \\ & \text { patient educator then provided peer support, education and/or referral to the social worker if the patient needed } \\ & \text { additional help. Arthritis Foundation pamphlets were used as an adjunct to the educational component. One week } \\ & \text { after the appointment, the arthritis patient educator provided a follow-up phone call to determine whether the patient } \\ & \text { had any questions since his or her rheumatologist's appointment.Arthritis patient educators are persons with arthritis, } \\ & \text { selected by their rheumatologists to participate in the above-described training course. Additional training was given } \\ & \text { during an intensive 2-day training programme prepared by a panel of experts. Topics included: rheumatic disease } \\ & \text { pathophysiology, nutritional guidelines, psychosocial aspects of chronic illness, components of physical therapy in- } \\ & \text { cluding exercise and pain management, and components of occupational therapy including exercise, joint protection, } \\ & \text { and energy conservation; and discussions of cultural diversity and cross cultural differences in disease perceptions } \\ & \text { and interviewing and listening skills. } \\ & \text { Controls: Standard rheumatologic care. }\end{aligned}$
$\begin{aligned} & \text { Included: None. } \\ & \text { Not reported: AIMS2 (pain, physical, arthritis impact, affect, anxiety and depression). } \\ & \text { Others: Arthritis Self-Efficacy Scales, a basic arthritis knowledge test, and satisfaction with services questionnaire. }\end{aligned}$
$\begin{aligned} & \text { ACR = American College of Rheumatology } \\ & \text { AIMS = Arthritis Impact Measurement Scales }\end{aligned}$

\section{Brus 1998}

Methods An assessor blinded, one year study. 65 RA- patients were selected, results presented of 25 experimental and 30 controls who finished the study.

Assessments were done at baseline and after 3, 6 and 12 months.

Quality: 0/1/1/2

Participants 65 RA-patients randomised (32 exp/33 contr), 5 drop-outs (3/2) at baseline, 2 at 6 months ( 1 each) and $3 \exp$ at 12 months, leaving 55 (25/30) for analysis. Inclusion: less than 3 years RA, active disease (ESR $>28 \mathrm{~mm} / \mathrm{h}$ and $>5$ painful and $>3$ swollen joints) and on DMARD therapy with sulphasalazine. DMARDs other than hydroxychloroquine were excluded. Mean age: 59.2 yrs, $80 \%$ female and mean number of ACR criteria: 4.7.

Interventions Experimental Group: Four $(2 \mathrm{~h})$ goup meetings in the first month, with reinforcement meetings after 4 and 8 months, partners were invited. Focus on compliance with sulphalazine therapy, physical exercises, endurance activities, advice on energy conservation and joint protection. One instructor (HB) provided information on RA, attendant problems and basic treatment. Sessions included discussion of problems and solutions, training in physical exercises, treatment planning, use of contracts and feedback.

Controls: no intervention

Outcomes Included: Dutch-AIMS (pain, anxiety and depression), M-HAQ, Ritchie Articular Index, ESR. Not reported: Dutch-AIMS (mobility, physical activity, dexterity and household activities).

Others: CRP,

number of swollen joints, number of painful joints, DAS. 


\section{Brus 1998 (Continued)}

ESR $=$ erythrocyte sedimentation rate
DMARD = disease modifying anti-rheumatic drug
ACR $=$ American College of Rheumatology
AIMS = Arthritis Impact Measurement Scales
M-HAQ = Modified Health Assessment Questionnaire
DAS = Disease Activity Score

\section{Cohen 1986}

Methods 3 months Randomised Controlled Trial.
Assessments were done at baseline, after 6 weeks (experimental groups only) and after 12 weeks.
Quality: 0/0/1/0

Participants 96 arthritis patients randomised (28 prof/32 lay/36 contr), 10 drop-outs (4/4/2), leaving 86 (24/28/34) for analysis, $15 \%$ RA ( $\mathrm{n}=14)$. Volunteers through public service announcements. Diagnosis determined by patient's physician. Mean age: $65.5 \mathrm{yr}, 78 \%$ female.

Interventions Professional-instructed: 6 weekly $(2 \mathrm{hr})$ sessions (10 persons) of arthritis self-management course (modeled after Lorig). Including: exercise techniques, relaxation, joint protection, heat therapy, massage, medications, diets, physician-patient communication and solving social/functional problems. Led by 2 health professionals who acted as expert authorities rather than equals.

Controls: no intervention.

$\begin{array}{ll}\text { Outcomes } & \text { Included: None. } \\ & \text { Not reported: VAS-pain, M-HAQ, CES-D. }\end{array}$

$\begin{array}{ll}\text { Notes } & \text { VAS }=\text { Visual Analogue Scale } \\ \text { M-HAQ }=\text { Modified-Health Assessment Questionnaire } \\ \text { CES-D }=\text { Center for Epidemiologic Studies-Depression Scale }\end{array}$

\section{Cohen 1986-B}

\begin{tabular}{l|l} 
Methods & \\
\hline Participants & $\begin{array}{l}\text { Lay-led: Same course, led by } 2 \text { leaders, who had completed a } 16 \text { hr training training course and one of whom had } \\
\text { arthritis. Leaders were regarded as group members, not experts. } \\
\text { Controls: no intervention. }\end{array}$ \\
\hline Interventions \\
\hline Outcomes & \\
\hline Notes & \\
\hline
\end{tabular}


Cziske 1987

\begin{tabular}{ll} 
Methods & $\begin{array}{l}\text { A } 4 \text { week intervention with } 4 \text { rheumatic conditions. } \\
\text { Assessments were done at baseline and immediately after the } 4 \text { weeks intervention period. } \\
\text { Quality: 0/0/0/0 }\end{array}$ \\
\hline Participants & $\begin{array}{l}44 \text { arthritis patients randomised and analysed (25 exp/19 contr); } 9 \text { RA (4/5). Inclusion: considerable pain, disease } \\
\text { duration at least } 6 \text { months, no other relevant comorbidities, having RA, OA, ankylosing spondylitis or low-back pain. }\end{array}$ \\
\hline Interventions & $\begin{array}{l}\text { Pain-management training: } 4 \text { sessions ( } 90 \text { min, } 4 \text { persons with same disease) including: gate-control theory of pain, } \\
\text { presentation of and training in breathing techniques, distraction and visualisation; and how to incorporate techniques } \\
\text { in daily life. } \\
\text { Controls: lecture (90 min) on pain management }\end{array}$ \\
\hline Outcomes & $\begin{array}{l}\text { Included: None. } \\
\text { Not reported: Revidierte Mehrdimensionale Schmerz-Skala (pain-RMSS), Befindlichkeitsskala (disability), Trait } \\
\text { Anxiety (State-Trait Anxiety Inventory). }\end{array}$ \\
\hline Notes & \begin{tabular}{l} 
Con \\
\hline
\end{tabular}
\end{tabular}

\section{Daltroy 1998}
Methods A 4-days randomised controlled prospective study of two interventions, information and relaxation training, in a 2x2 factorial design. Assessments were done at baseline and 4 days post intervention. Quality: 0/1/1/1

Participants From March 1985 until December 1987 letters were mailed to 329 eligible patients of 8 orthopaedic surgeons. Of these, 247 (82\%) agreed to participate. In 25 cases surgery was cancelled, leaving 222 patients with completed baseline data and exposure to the intervention (I1: 58, I2: 58, I3: 52, C: 54). One patient was excluded from analyses (outlier for all outcomes), 5 patients were excluded due to incomplete data.

Number randomised: not stated, nor for total nor for RA.

Number analysed: 216 patients. $(19 \%$ RA-patients $=42)$. Inclusion: Eligible patients were those scheduled for total hip or knee replacement surgery. Patients were excluded if they could not speak English, fill out the questionnaires, or if they had previously had surgery on the contralateral joint. Mean age: 64 years (SD: 12). Range: 20-88 years, $66 \%$ female. $19 \%$ RA; $73 \%$ OA; $8 \%$ other. One or more comorbidities: $33 \%$. Uses pain medication 5-7 days per week: $78 \%$.

Interventions Information only - The informational intervention consisted of a 12-min audiotape slide programme presented by a research assistant at the patient's bedside the day before surgery. The audiotape oriented the patient to the hospital, to staff and their roles, to the events of surgery and rehabilitation, and to life in the hospital. Patients were told of various stressful aspects of the hospitalisation., including postoperative pain, immobility, the work involved in rehabilitation, lights and noises, an altered sleep schedule, and dietary and smoking restrictions. They were reassured that various sensations, emotions and difficulties were normal and would pass.

Controls: no intevention.

Outcomes Included: none.

Not reported: Pain (assessed by taking the mean of 3 5-point Likert scales assessing pain (not at all to extremely painful) at night, resting and when active); State anxiety (Spielberger's 20-item anxiety inventory).

Notes 


\section{Daltroy 1998-B}

\begin{tabular}{l|l}
\hline Methods & \\
\hline Participants & $\begin{array}{l}\text { Relaxation training only - Oral and written instructions, along with an 18-min audiotape and portable tape player } \\
\text { with earphones. Patients were instructed the day before surgery in the relaxation response and asked to practice with } \\
\text { the tape before surgery. They were instructed how to use the tape and relaxation response postoperatively to lessen } \\
\text { discomfort and anxiety, and the tape and player were left at the bedside. One to two days after surgery, the research } \\
\text { assistant reminded the patient to use the technique. } \\
\text { Controls: no intevention. }\end{array}$ \\
\hline Outcomes & $\begin{array}{l}\text { Nontions } \\
\text { Notes }\end{array}$ \\
\hline
\end{tabular}

\section{Daltroy 1998-C}

\begin{tabular}{l|l}
\hline Methods & \\
\hline Participants & \\
\hline $\begin{array}{l}\text { Interventions } \\
\text { Information plus relaxation training. See I1 and I2. The relaxation response was taught after the informational } \\
\text { audiotape for patients assigned to both interventions. } \\
\text { Controls: no intevention. }\end{array}$ \\
\hline Outcomes & \\
\hline Notes &
\end{tabular}

\section{Fries 1997}

\begin{tabular}{l|l} 
Methods & $\begin{array}{l}\text { A } 6 \text { months cross-over study. } \\
\text { Assessments were done at baseline and } 6 \text { months later. } \\
\text { Quality: } 1 / 1 / 2 / 1\end{array}$ \\
\hline Participants & $\begin{array}{l}1099 \text { respondents from three groups were recruited and seperately randomised }(557 \text { exp/542 contr): Physician } \\
\text { diagnosed OA and RA-patients from a HMO, Physician referrals from } 3 \text { rheumatology practices and self-reported } \\
\text { arthritis from a general health education programme. } 809(375 / 434) \text { patients analysed at } 6 \text { months and } 392(248 / 144) \\
\text { at } 12 \text { months. }\end{array}$
\end{tabular}

Interventions Mail delivered intervention at 3 months intervals. HAQs lead directly to computer generated recommendation letters with physician signature and graphic reports of progress. Positive change is reinforced and additional change encouraged every 3 months. Including exercise video and relaxation audiotape. Recommendations were tailored for age, diagnosis, level of disability, education level, medication schedule, side-effects, pain, self-efficacy, etc. Advice given is closely similar to that in Lorig's 'The Arthritis Helpbook'.

Controls: not reported (no-intervention). 
Fries 1997 (Continued)

\begin{tabular}{ll}
\hline Outcomes & $\begin{array}{l}\text { Included: None. } \\
\text { Not reported: VAS-pain, HAQ, joint count, VAS-global vitality. } \\
\text { Others: confidence (self-efficacy). }\end{array}$ \\
\hline Notes & $\begin{array}{l}\text { HMO }=\text { Health Maintenance Organization } \\
\text { VAS }=\text { Visual Analogue Scale } \\
\text { HAQ }=\text { Health Assessment Questionnaire }\end{array}$ \\
\hline
\end{tabular}

\section{Geissner 1994}

\begin{tabular}{ll} 
Methods & $\begin{array}{l}\text { Parallel treatment during } 4 \text { to } 6 \text { weeks rheumatology clinic admission. Co-interventions not allowed. } \\
\text { Assessments were done at baseline and after the } 4 \text { to } 6 \text { weeks intervention period. } \\
\text { Quality: 0/2/0/0 }\end{array}$ \\
\hline Participants & $\begin{array}{l}\text { 60 RA patients recruited, } 14 \text { drop-outs before randomisation, } 46 \text { (12 MPM/10 VT/ } 12 \text { RT/ 12 Contr) randomised } \\
\text { and analysed. Inclusion: definite diagnose of RA and chronic pain during at least } 6 \text { months. Mean age } 47.5 \text { yr and } \\
78 \% \text { female. }\end{array}$ \\
\hline Interventions & $\begin{array}{l}\text { Multimodal Pain Management (MPM): } 6 \text { sessions }(90 \text { min) icluding pain information, presentation of coping } \\
\text { strategies and training. } \\
\text { Controls: medical treatment alone. }\end{array}$ \\
\hline Outcomes & $\begin{array}{l}\text { Included: AES (pain), Behinderungserleben (disability), Gelenkstatus (joint count), HDA (psychological status), } \\
\text { ESR. } \\
\text { Others: Beck-hopelessness scale; Optimismusskala (Optimism). }\end{array}$ \\
\hline Notes & $\begin{array}{l}\text { AES }=\text { Affektiv-evaluative Schmerzangabe } \\
\text { HDA }=\text { Schmerz bezogene Hilfosigkeit, Depression und Angst } \\
\text { ESR }=\text { erythrocyte sedimentation rate }\end{array}$ \\
\hline
\end{tabular}

\section{Geissner 1994-B}

Methods

\begin{tabular}{ll}
\hline Participants & \\
\hline Interventions & $\begin{array}{l}\text { Visualisation Techniques (VT): } 6 \text { sessions }(90 \text { min) including: influence of thinking on function. visualisation of } \\
\text { rest, and strenght and visualisation of forces against pain and illness. } \\
\text { Controls: medical treatment alone. }\end{array}$ \\
\hline Outcomes & \\
\hline Notes & \\
\hline
\end{tabular}


Geissner 1994-C

\begin{tabular}{l|l}
\hline Methods & \\
\hline Participants & \\
\hline Interventions & $\begin{array}{l}\text { Relaxation Training (RT): } 6 \text { sessions }(90 \text { min) including instructions and training in Jacobson's relaxation. } \\
\text { Controls: medical treatment alone. }\end{array}$ \\
\hline Outcomes & \\
\hline Notes & \\
\hline
\end{tabular}

\section{Goeppinger 1989}

\begin{tabular}{|c|c|}
\hline Methods & A 4 months cross-over study. Assessments were done at baseline and after 4 months. Quality: 0/0/1/0 \\
\hline Participants & $\begin{array}{l}459 \text { arthritis patients randomised, } 85 \text { drop-outs, leaving } 374 \text { (121 HS/100 SG/153 Contr) for analysis, 16\% RA } \\
(\mathrm{N}=60) \text {. Inclusion: } 18 \mathrm{yr} \text { or older, medically verified diagnosis of arthritis, sixth grade reading level or above, non- } \\
\text { housebound and resident in } 1 \text { of } 9 \text { selected rural counties. Mean age total group: } 62.44 \text { (sd 11.25), } 87 \% \text { female. }\end{array}$ \\
\hline Interventions & $\begin{array}{l}\text { SG - small group: } 6 \text { sessions ( } 2 \mathrm{hr} \text { each) in community sites led by } 2 \text { trained lay leaders. Contents: encourage active } \\
\text { pratice of self-care, contracts and feedback and problem-solving. Topics: exercise, energy conservation and joint } \\
\text { protection, depression, medications, nutrition and diet, sleep, family relationships, community resources, folk or } \\
\text { popular medicines and working with physicians. WLC - Waiting list controls }\end{array}$ \\
\hline Outcomes & Included: None. Not reported: Pain Index, HAQ, CES-D). Others: AHI. \\
\hline Notes & $\begin{array}{l}\text { HAQ = Health Assessment Questionnaire CES-D = Center for Epidemiologic Studies Depression Scale AHI = } \\
\text { Arthritis Helplessness Index }\end{array}$ \\
\hline
\end{tabular}

\section{Goeppinger 1989-B}

Methods

\begin{tabular}{l|l} 
Participants & \\
\hline Interventions & $\begin{array}{l}\text { HS - home study: } 6 \text { lessons, each with a booklet and audiotaped instruction, mailed to participants at home. Contents: } \\
\text { same as SG. } \\
\text { WLC - Waiting list controls }\end{array}$ \\
\hline Outcomes & \\
\hline Notes & \\
\hline
\end{tabular}


Interventions Intervention: Four weekly $2 \mathrm{hr}$ sessions, plus an optional home visit within 2 weeks of the end of the programme, led by an experienced rheumatology occupational therapist. Partners or significant others were invited to attend. Between 4 and 8 people attended each programme. A teaching manual was followed throughout to standardise the programme content and delivery. Patients were provided with a workbook "Managing Your Arthritis: Joint Care Workbook', "Coping with Rheumatoid Arthritis" and patient education leaflets produced by the Arthritis and Rheumatism Council (ARC). The ARC videotape 'Help is at hand - getting the better of your arthritis' is shown at the first meeting to promote discussion of members' own alternate methods and gadgets they found useful, as well as on the impact of living with arthritis. The programme used the Health Belief Model and Self-efficacy Theory as a basis. The programme focussed on barriers to adhering with JP such as: poor self-efficacy for using JP (modelling on other group members' JP performance and verbal persuasion), limited perceived susceptibility to the effects of RA (educating about the effects of RA on joints, etc.), poor recall of JP methods (advance organisers, simplification, explicit categorisation, specific advice and repetition), limited skill (motor learning strategies)and difficulty with habit formation (self-management strategies such as contracting and goal-setting).

Controls: waiting list control group.

Outcomes Included: HAQ, HAQ Pain Scale (patients are asked to rate their perceived pain during performance of 8 activities derived from the HAQ).

Others: Joint Protection Behaviour Assessment, Self-reported JP homework practice, Joint Protection Knowledge Assessment, Arthritis Helplessness Index, Arthritis Self-efficacy Scale, Hand Pain Visual Analogue Scale, Hand Joint Count, Hand Joint Alignment and Motion Scale, Grip strength.

Notes $\quad \mathrm{HAQ}=$ Health Assessment Questionnaire

$\mathrm{JP}=$ Joint Protection.

\section{Helewa 1991}

Methods A 6 week, cross-over study.

Assessments were done at baseline and after 6 weeks.

Quality: 1/0/2/1

Participants 105 RA-patients randomised (53 exp/52 contr), 3 (1/2) drop-outs after 6 weeks. Inclusion: age: 18-70 yr, definite or classical RA according to 1987 ARA criteria, limitations in physical function, no other sources of disability, stable clinical status, no intra-articular treatment last 2 months, no joint surgery for RA last 3 months and coming 6 weeks. Exclusion: pregnant or disease onset before age 16. Mean age: $54 \mathrm{yr}$ (sd: 12.2), 87\% female. 


\section{Helewa 1991 (Continued)}

\begin{tabular}{ll} 
Interventions & $\begin{array}{l}\text { A } 6 \text { week programme of occupational therapy: total evaluation of disease activity and level of function }+ \text { physical } \\
\text { examination + functional evaluation of daily tasks. Formulation of a problem list and treatment plan. More detailed } \\
\text { evaluations of hand and feet if required. Enhancement of ADL by provision of aids, home adaptations, wheelchair } \\
\text { prescription, education, joint protection and energy conservation. If appropriate: vocational assessment, ehancement } \\
\text { of leisure activities, psychosocial counselling and socialising skills. } \\
\text { Waiting List Controls. }\end{array}$ \\
\hline Outcomes & $\begin{array}{l}\text { Included: HAQ, Beck-depression. } \\
\text { Not reported: VAS-pain, Active joints count, ESR. }\end{array}$ \\
\hline Notes & $\begin{array}{l}\text { ARA }=\text { American Rheumatology Association } \\
\text { ADL }=\text { Activities of Daily Living } \\
\text { VAS }=\text { Visual Analogue Scale } \\
\text { HAQ }=\text { Health Assessment Questionnaire } \\
\text { ESR }=\text { erythrocyte sedimentation rate }\end{array}$
\end{tabular}

\section{Helliwell 1999}

Methods A 12-months randomised controlled trial in people with rheumatoid arthritis of $<5 \mathrm{yr}$ duration. Control patients could attend education classes after the 12-month study if such classes were found of benefit. Assessments were done at baseline, 4 weeks and 12 months.

Quality: 2/2/2/1

Participants 79 patients were randomised, 77 analysed (I: 43; C: 34). Inclusion: Patients from routine out-patient clinic appointments, with a diagnosis of rheumatoid arthritis (using the 1987 ARA criteria) of < $5 \mathrm{yr}$ duration who were able to read and speak English.No previous participation in a group patient education programme.

Mean age: $53.2 \mathrm{yr}$, range: $23-78,66 \%$ (51/77) female. Mean duration of disease: $3.2 \mathrm{yr}$.

Interventions A 4-week education programme, with $2 \mathrm{~h}$ weekly sessions. Participants were encouraged to bring a partner. The format of the sessions was a talk from a non-medical health professional using overhead projection, a discussion period and the distribution of supporting literature. The content of the sessions included the pathophysiology of rheumatoid arthritis, drug treatments, local treatments, mechanisms and control of pain, stress, exercise and rest, joint protection, task allocation, splinting and assistive equipment.

Controls: Usual care, control patients could attend education classes after the 12-month study if such classes were found of benefit.

Outcomes Included: SF-36 (at baseline and 12-months: Bodily pain, General health perception, and Mental health), HAQ, Ritchie Articular Index, and Plasma viscosity (PV).

Others: The modified Larsen radiological score for the hands and wrists, Patient Knowledge Questionnaire (PKQ), Compliance Questionnaire (CQ), pharmaceutical changes and consulting behaviour.

$\begin{array}{ll}\text { Notes } & \text { ARA }=\text { American Rheumatology Association } \\ & \text { HAQ }=\text { Health Assessment Questionnaire } \\ \text { SF-36 }=\text { Medical Outcome Survey }- \text { Short Form 36-item version }\end{array}$




\section{Hewlett 1999}

\begin{tabular}{|c|c|}
\hline Methods & $\begin{array}{l}\text { A } 36 \text { weeks study. } \\
\text { Assessments were done at baseline, after } 8 \text { weeks and after } 36 \text { weeks. } \\
\text { Quality: } 2 / 1 / 2 / 1\end{array}$ \\
\hline Participants & $\begin{array}{l}79 \text { RA-patients were randomised ( } 34 \text { education/34 controls/11 declined education and were followed as an observa- } \\
\text { tion group for ITT analysis). } 11 \text { drop-outs }(4 / 6 / 1) \text {, leaving analysis on } 68(30 / 28 / 10) \text {. Inclusion: age } 18-70 \text {, positive } \\
\text { RA-factor, evidence of current inflammation (CRP }>10 \text { and/or } 5+\text { swollen joints). Exclusion: previous education } \\
\text { programme. } \\
\text { Mean age: } 56.79 \text { y (SD:10.63), } 69 \% \text { female. }\end{array}$ \\
\hline Interventions & $\begin{array}{l}\text { Group Education: } 5 \text { sessions }(2.5 \mathrm{hr}) \text {, including joint protection, relaxation, pain management, stress and mood } \\
\text { management. Run by nurses, occupational therapists, physiotherapists and a psychologis. } \\
\text { Controls: No additional intervention. }\end{array}$ \\
\hline Outcomes & Included: VAS-pain, HAQ, Thompson-score (joints count), HADS (anxiety and depression), CRP. \\
\hline Notes & $\begin{array}{l}\text { VAS }=\text { Visual Analogue Scale } \\
\mathrm{HAD}=\text { Hospital Anxiety and Depression Scale } \\
\mathrm{CRP}=\text { C-reactive protein }\end{array}$ \\
\hline
\end{tabular}

\section{Hill 2001}

Methods A 6-months randomised controlled study comprising 100 patients with rheumatoid arthritis requiring D-penicillamine (DPA).Patients were stratified into bands of low, medium or high knowledge of their RA.

Assessments were done at baseline and after 24 weeks.

Quality: 2/2/0/2

Participants 100 patients, referred by their rheumatologist, were recruited and randomised (I: 51; C: 49); 63 patients completed the full 24 weeks of the study and were analysed (I: 33; C: 30).

Inclusion: Patients with active RA from an outpatient clinic. All were deemed to require DPA as their slow acting antirheumatic drug (SAARD). Age: 18 years or above; a positive diagnosis of RA using the American Rheumatism Association criteria, a plasma viscosity $>=1.75 \mathrm{mPa} . s$ or a CRP $>10 \mathrm{mg} / \mathrm{l}$. In addition: two out of three clinical features: an articular index $>15$, morning stiffness $>45$ minutes, a minimum of moderate levels of pain.

Patients were excluded if they had received DPA previously, had a contraindication such as kidney impairment or pregnancy, or were receiving incompatible concomitant drugs; or awaiting hospital admission.

Median age: 63 years, range: 22 to 79 years, 73 females (73\%). Median duration of RA: 13 years (range: 0-45 years).

Interventions Intervention: 7x30 minute one-to-one sessions of patient education over a 6 months period. The programme was based on the theory of self-efficacy and taught by a rheumatology nurse practitioner. The programme comprised information about the types drugs use for RA, the disease process, physical; exercise, joint protection, pain control, and coping strategies. Written information, including a DPA drug information leaflet developed specially for the study, was provided as back up.

Controls: Standard management and received the same drug information leaflet. Control patients were invited for 7 sessions of 30 minutes over a 6 months period to talk about their social lives and families.

Outcomes Included: Pain score (daily diary card, 1=no pain, 5=very severe), Ritchie articular index, C reactive protein (CRP). Others: Measure of adherence: Pharmacological marker (phenobarbitone)., Plasma viscosity, and morning stiffness. 
Hill 2001 (Continued)

Notes $\quad$ DPA $=$ D-penicillamine

\section{Huiskes 1991}

\begin{tabular}{ll} 
Methods & $\begin{array}{l}\text { An } 8 \text { months, waiting-list control and outcome assessor blinded study. } \\
\text { Assessments were done at baseline, after } 10 \text { weeks and } 6 \text { months after the } 10 \text { weeks patient education period. } \\
\text { Quality: 0/0/1/1 }\end{array}$ \\
\hline Participants & $\begin{array}{l}\text { 105 RA-patients randomised ( } 21 \text { CT/24 CBT/28 OT/19 WLC), } 13 \text { drop-outs (3/3/3/4). Inclusion: minimum age } \\
\text { of } 20 \text { yr, diagnose of RA according to } 1987 \text { ACR-criteria for at least } 1 \text { yr. Exclusion: difficulty ambulating due to } \\
\text { aging or medical problems, and class } 4 \text { RA. Mean age } 57 \text { yr (sd: } 12.7 \text { ) and } 68 \% \text { female. }\end{array}$ \\
\hline Interventions & $\begin{array}{l}\text { CT - Combination of Cognitive Behavioral Therapy and Occupational Therapy. } \\
\text { WLC - Waiting List Controls. }\end{array}$ \\
\hline Outcomes & $\begin{array}{l}\text { Included: IRGL (pain, mobility, mood, anxiety, depression), Thompson-score (joint count), ESR. } \\
\text { Others: IRGL (self-care), CRP. }\end{array}$ \\
\hline Notes & $\begin{array}{l}\text { WLC }=\text { Waiting List Controls } \\
\text { CT }=\text { Combination Therapy } \\
\text { IRGL = Impact of Rheumatic diseases on Health and Lifestyle } \\
\text { ESR }=\text { Erythrocyte Sedimentation Rate } \\
\text { CRP = C-reactive protein }\end{array}$ \\
\hline
\end{tabular}

Huiskes 1991-B

\begin{tabular}{l|l}
\hline Methods & \\
\hline Participants & \\
\hline Interventions & $\begin{array}{l}\text { CBT }-10 \text { weekly, } 2 \text { hr sessions, including biomedical information, assessment of patients coping repertoire + self- } \\
\text { management of active coping behaviour, training of progressive relaxation, rational thinking, active coping behavior } \\
\text { and goal-setting. With homework assigned, discussed and evaluated. } \\
\text { WLC - Waiting List Controls. }\end{array}$ \\
\hline Outcomes & $\begin{array}{l}\text { WLC }=\text { Waiting List Controls } \\
\text { CBT }=\text { Cognitive Behavioural Therapy }\end{array}$ \\
\hline Notes &
\end{tabular}

\section{Huiskes 1991-C}

\section{Methods}

\section{Participants}


Huiskes 1991-C (Continued)

\begin{tabular}{ll} 
Interventions & $\begin{array}{l}\text { OT }-10 \text { weekly, } 2 \text { hr sessions, including biomedical information, energy conservation, joint protection, use of devices, } \\
\text { exercises, maitenance of joint mobility. With homework assigned, discussed and evaluated. } \\
\text { WLC - Waiting List Controls. }\end{array}$ \\
\hline Outcomes & \\
\hline Notes & $\begin{array}{l}\text { WLC }=\text { Waiting List Controls } \\
\text { OT }=\text { Occupational Therapy }\end{array}$ \\
\hline
\end{tabular}

\section{Kaplan 1981}

\begin{tabular}{ll} 
Methods & $\begin{array}{l}\text { A } 16 \text { week, outcome assessor blinded, group counselling programme. } \\
\text { Assessments were done before the patient education session for all respondents, } 2 \text { weeks later (baseline) and } 16 \text { weeks } \\
\text { later (post-test). } \\
\text { Quality: 0/0/1/1 }\end{array}$ \\
\hline Participants & $\begin{array}{l}34 \text { female RA patients randomised (17 each), } 6 \text { drop-outs (exp): } 4 \text { non-compliant, } 1 \text { moved, } 1 \text { refused final test). } \\
\text { Inclusion: definite or classical RA according to ARA criteria, age between } 21 \text { and } 65 \text { yr and willingness and ability to } \\
\text { attend } 20 \text { weekly sessions. Mean age: } 49 \text { yr; } 100 \% \text { female; } 21 \% \text { ARA-class } 1,50 \% \text { class } 2 \text { and } 29 \% \text { class } 3 .\end{array}$
\end{tabular}

Interventions All: patient education session $(2.5 \mathrm{hr})$. Including: pathophysiology, treatment and complications by rheumatologist; physical and occupational therapeutic modalities plus demonstrations by OT; eligibility and availability of programmes for chronic patients by social worker.

EG - 12 weekly (1-2 hr) group counselling sessions, free discussion encouraged, but emphasis on problems caused by arthritis. Led by a patient counsellor and psychiatrist.

CG - No additional meetings.

Outcomes Included: Zung self-rating depression scale.

Not reported: Joint counts, joint tenderness (dolorimeter), subjective impression of disease activity by rheumatologist.

Notes $\quad$ ARA $=$ American Rheumatism Association
OT $=$ Occupational Therapist
EG $=$ Experimental Group
CG $=$ Control Group
Test 2 (after first education session, before randomisation)= Pre-test; Test 3 (after 12 weeks counseling)= post-test

\section{Leibing 1999}

\begin{tabular}{ll} 
Methods & $\begin{array}{l}\text { A 9-months prospective randomised controlled trial. Change in medication during treatment was controlled by } \\
\text { matching therapy and control group participants according to this change in medication, sex, age, duration of disease } \\
\text { and functional class. Medication was not prescribed during treatment. Assessments were done at baseline, and after } \\
3 \text { and } 9 \text { months. } \\
\text { Quality: } 0 / 2 / 1 / 1\end{array}$ \\
\hline Participants & $\begin{array}{l}118 \text { consecutive outpatients were seen. } 63 \text { met the criteria and were included. } 55 \text { patients were randomised (although } \\
\text { not explicitly stated; could also be } 63) .55 \text { patients finished the study and were analysed (I: } 19 \text {, C: } 36 \text { ). Inclusion: } \\
\text { Diagnosis of rheumatoid arthritis (ACR criteria). Exclusion criteria: duration of disease of } 0.5 \text { years or less, another }\end{array}$
\end{tabular}




\section{Leibing 1999 (Continued)}

severe disease, planned hospitalisation, organic brain syndrome, no pain, or advanced disability (functional class IV). Mean age: 52.7 years (SD: 11.9), 74.5\% female. Mean duration of disease: 9.4 years (SD: 9.3). 26 patients (67\%) were functional class II and 8 (21\%) functional class III.

Interventions Intervention: Routine care by the rheumatologist and adjunctive standardised cognitive-behavioural group treatment (5-7 patients) with 12 weekly 90-minute manual based sessions, designed after the approach by Turk and Rudy, a common basis for cognitive-behavioural therapies for pain. The following strategies were included: information an education about the gate-control theory of pain, the vicious circle of pain, muscular tension, demoralisation, and the rational of the treatment methods; relaxation and imagery; cognitive-behavioural treatment interventions and pain management strategies; and pleasant activity scheduling. Sessions were led by 2 experienced instructors ( $>5$ years of psychotherapeutic experience)

Controls: Routine care by the rheumatologist and routine medical treatment (n=36, "change-in-medication-matched control group": $n=20$ )

Outcomes Included: Pain intensity, Functional capacity (Hannover Functional Ability Questionnaire), Number of swollen joints, State-Trait Anxiety Inventory, Depression scale, ESR.

Others: Affective pain, CRP, grip strength, Arthritis Helplessness Index, Bernese Coping Modes.

Notes $\quad$ ACR $=$ American College of Rheumatology

$\mathrm{ESR}=$ Erythrocyte Sedimentation Rate

$\mathrm{CRP}=\mathrm{C}$-reactive protein

\section{Lindroth 1997}

Methods A one year study with waiting list controls.

Assessments were done at baseline and 3 and 12 months after the intervention.

Quality: 0/1/2/0

Participants 100 consecutive patients with RA according to 1987 ACR criteria. All patients completed the intervention, 4 patients were lost to follow-up ( 2 refused, 1 death, 1 ill). Mean age: 55 yr; $83 \%$ female.

Interventions 8 weekly $(2,5 \mathrm{~h}$ ) group discussions led by a team (doctor, nurse, PT, OT, social worker and dietitian). First session: introduction, leisure priorities and main problems. Folowing sessions: problem solving; therapy; diets; pain management, rest, exercise and relaxation; pain relief, home exercises; hand function and aids; social problems; daily problems and tools; discussion with family and friends. One yr later informal meeting (problems with feet).

\begin{tabular}{ll} 
Outcomes & $\begin{array}{l}\text { Included: VAS-pain, HAQ. } \\
\text { Others: AHI. }\end{array}$ \\
\hline \multirow{2}{*}{ Notes } & ACR $=$ American College of Rheumatology \\
& PT $=$ Physiotherapist \\
& OT $=$ Occupational therapist \\
& VAS $=$ Visual Analogue Scale \\
& HAQ $=$ Health Assessment Questionnaire \\
& AHI $=$ Arthritis Helplessness Index
\end{tabular}




\section{Lorig 1985}

\begin{tabular}{ll}
\hline Methods & $\begin{array}{l}\text { A } 4 \text { months, community based, cross-over study. } \\
\text { Assessments were done at baseline and after } 4 \text { months. } \\
\text { Quality: 0/0/1/0 }\end{array}$ \\
\hline Participants & $\begin{array}{l}199 \text { arthritis patients randomised (134 exp/65 contr), } 9 \text { drop-outs }(5 / 4), 10.7 \% \mathrm{RA}(\mathrm{N}=31) \text {. Diagnosis confirmed } \\
\text { by their physician. Recruited by public service announcements. Mean age } 67.4 \text { (SD=11.84), 83\% female. }\end{array}$ \\
\hline Interventions & $\begin{array}{l}\text { Arthritis Self-Management Programme: } 6 \text { sessions }(15-20 \text { persons, plus family) in } 4 \text { months, taught by } 2 \text { lay leaders. } \\
\text { Including: nature of arthritis, use of medications, range of motion and isometric exercises, relaxation techniques, joint } \\
\text { protection, nutrition, patient-physician interaction and evaluation of non-traditional treatments. Based on group } \\
\text { discussion, practice, use of contracts and diaries to improve compliance and weekly feedback. } \\
\text { Controls: waiting list controls. }\end{array}$ \\
\hline Outcomes & $\begin{array}{l}\text { Included: None. } \\
\text { Not reported: VAS-pain, Ordinale pain scale (mild, moderate, severe), HAQ. } \\
\text { Others: Wallston Health Locus of Control. }\end{array}$ \\
\hline Notes & $\begin{array}{l}\text { VAS = Visual Analogue Scale } \\
\text { HAQ = Health Assessment Questionnaire }\end{array}$ \\
\hline
\end{tabular}

\section{Lorig 1986}

\begin{tabular}{|c|c|}
\hline Methods & $\begin{array}{l}\text { A } 4 \text { months, cross-over study. } \\
\text { Assessments were done at baseline and after } 4 \text { months. } \\
\text { Quality: 0/0/1/0 }\end{array}$ \\
\hline Participants & $\begin{array}{l}100 \text { arthritis patients randomised }(34 \mathrm{HP} / 34 \text { Lay/32 Contr), } 15 \text { drop-outs after } 4 \text { months }(5 / 7 / 3) \text {. From the final } \\
\text { sample of } 85 \text { patients, } 12 \text { had RA }(3 / 4 / 5) \text {. Diagnoses confirmed by their physician. Inclusion: Volunteers recruited } \\
\text { by use of public service. Mean age: } 64.4 \mathrm{yr}, 73 \% \text { female. }\end{array}$ \\
\hline Interventions & $\begin{array}{l}\text { HP-led: } 6 \text { weekly ( } 2 \mathrm{hr} \text { ) sessions ( } 15-20 \text { persons) ASM course at community sites, including: types of arthritis, } \\
\text { ROM and isometric exercises, relaxation techniques, use of medication, nutrition, problem-solving, joint protection, } \\
\text { evaluation of non-traditional therapies and patient-physician communication. Led by rheumatologist and physical } \\
\text { therapist, who attended an } 18 \mathrm{hr} \text { ASM leaders training programme and worked by a protocol. } \\
\text { Controls: no intervention. }\end{array}$ \\
\hline Outcomes & $\begin{array}{l}\text { Included: None. } \\
\text { Not reported: VAS-pain; HAQ. }\end{array}$ \\
\hline Notes & $\begin{array}{l}\text { HP }=\text { Health professional } \\
\text { ASM = Arthritis Self-Management } \\
\text { ROM = Range of Motion } \\
\text { VAS = Visual Analogue Scale. } \\
\text { HAQ = Health Assessment Questionnaire }\end{array}$ \\
\hline
\end{tabular}




\section{Lorig 1986-B}

\begin{tabular}{l|l}
\hline Methods & \\
\hline Participants & \\
\hline Interventions & $\begin{array}{l}\text { Lay-led: same ASM course, led by } 2 \text { lay leaders, one of whom had RA. } \\
\text { Controls: no intervention. }\end{array}$ \\
\hline Outcomes & ASM $=$ Arthritis Self-Management \\
\hline Notes &
\end{tabular}

\section{Lorig 1989}

\begin{tabular}{ll}
\hline Methods & $\begin{array}{l}\text { A 4 moths, cross-over study. } \\
\text { Assessments were done at baseline and after } 4 \text { months. } \\
\text { Quality: 0/0/1/0 }\end{array}$ \\
\hline Participants & $\begin{array}{l}854 \text { arthritis patients randomised (501 exp/206 contr), } 147 \text { drop-outs after } 4 \text { months: } 707 \text { analysed, } 14 \% \text { RA (N=99). } \\
\text { Inclusion: Volunteers through public service announcements, with a physician's confirmation of the diagnosis. Mean } \\
\text { age total group: } 64 \text { yr, } 84 \% \text { female. }\end{array}$ \\
\hline Interventions & $\begin{array}{l}\text { ASMC: } 6 \text { weekly }(2 \text { hr) sessions (15-20 persons, sometimes including family and friends), taught by } 2 \text { trained lay- } \\
\text { leaders. Content: pathophysiology of RA/OA, design of individual exercise and relaxation programme, medication } \\
\text { effects and treatment, joint protection, nutrition, decision making about non-traditional remedies, physician-patient } \\
\text { communication and problem-solving. } \\
\text { WLC: waiting list control group }\end{array}$ \\
\hline Outcomes & $\begin{array}{l}\text { Included: None. } \\
\text { Not reported: VAS-pain, HAQ, CES-D. }\end{array}$ \\
\hline Notes & $\begin{array}{l}\text { ASMC }=\text { Arthritis Self-Management Course } \\
\text { VAS = Visual Analogue Scale } \\
\text { HAQ = Health Assessment Questionnaire } \\
\text { CES-D = Center for Epidemiologic Studies Depression Scale }\end{array}$ \\
\hline
\end{tabular}

\section{Lorig 1999a}

Methods A 6-month randomised controlled trial at community based sites comparing treatment patients with waiting list control patients. Control patients received the programme after 6 months.

Assessments were done at baseline and after 6 months.

Quality: 0/0/2/2

Participants 1,140 patients responding to public service announcements in the mass media, referrals from flyers left in physician's offices and community clinics, posters at senior citizen centres, announcements in health maintenance organisation (HMO) patient newsletters, and referrals from county government employers were recruited and randomised (I: 664; C: 476). 952 (83\%) completed the 6-month study and were analysed (I: 561; C: 391). Arthritis patients: 521 (I: 314; C: 207).

Inclusion: patients 40 years of age or older with a physician-confirmed diagnosis of heart disease, lung disease, stroke 
or arthritis.

Patients with compromised mentation, and cancer patients who received chemotherapy or radiation within the past year were excluded.

Mean age: $65.4 \mathrm{yr}$, range: $40-90 \mathrm{yr}, 65 \%$ female.

Interventions Intervention: The Chronic Disease Self-management Program (CDSMP) is a community-based patient self-management education course. Sessions are led by two trained lay persons with chronic conditions. The programme was given in 7 weekly $2.5 \mathrm{~h}$ sessions. Topics included: exercise; use of cognitive symptom management techniques; nutrition; fatigue and sleep management; use of community resources; use of medications; dealing with the emotions of fear, anger and depression; communication with others including health professionals; problem-solving; and decision-making. The book: "Living a Healthy Life with Chronic Conditions" was used as a text for participants and details the content of the course. The process of teaching is based on Self-Efficacy Theory. Strategies include: weekly action planning, and feedback, modelling of behaviours and problem-solving by participants for one another, reinterpretation of symptoms by giving many possible causes for each symptom as well as several different management techniques, group problem-solving, and individual decision-making. Each course had 10-15 participants of mixed ages and diagnoses, including family members if they wished to attend. Controls: waiting list control group.

Outcomes Included: none.

Not reported: the pain and discomfort scale (an adaption of the Medical Outcomes Study (MOS) pain scale), HAQ, the psychological well-being scale from the SF-36 (MHI-5), and the health distress scale (adapted from the MOS health distress scale).

Others: a self-rated health scale used in the National Health Interview Survey, the energy/fatigue scale from the MOS, social/role activity limitations, shortness of breath, duration of exercise, use of cognitive symtom management, communication with physicians, visits to physicians, visits to hospitals during the past 6 months, and the number of nights spent in a hospital.

\section{Lorig 1999b}

Methods A 4-months randomised controlled trial comparing a community-based arthritis self-management programme for Spanish speaking participants with a waiting list control group. Control patients received the programme after 4 months.

Assessments were done at baseline and 4 months.

Quality: 0/0/2/0

Participants Respondents were recruited in cohorts every 4 months for 2 years. Number recruited not specified; probably 331, as authors state: 'All patients were included in the analyses'. 331 patients randomised (I: 219; C: 112), RA-patients: 25 (I: 14; C: 11). 86\% of 331 patients completed the 4-month data. (Number of RA-patients not specified). Inclusion: not stated. Mean age: 62.5 years, range: 18-93y. 84\% female. 25 RA (I: 14, C:11); 117 OA (I: 116, C:51); 19 other arthritis (I: 10, C: 9); 120 undiagnosed musculoskeletal symptoms (I: 79, C: 41). Patients' diagnoses were verified in most cases by their physician.

Interventions Intervention: The Spanish Arthritis Self-Management Programme (SASMP) is a 12-hour, community based programme given in 2-hour sessions over 6 weeks. It is taught in community settings by trained lay leaders, many of whom have arthritis. The leaders teach from a standardised protocol which details botyh the course content and process. Class sizes range from 10-15, including participants' familyand friends. Participants received a book: 'Una guia para una vida activa y saludable', an audio exercise tape and illustrated booklet of the exercises routines, and an 


\section{Lorig 1999b (Continued)}

audio relaxation tape. The programme is taught using techniques to enhance self-efficacy.

Controls: waiting list control group.

\begin{tabular}{ll} 
Outcomes & $\begin{array}{l}\text { Included: none. } \\
\text { Not reported: a visual numeric scale for pain, HAQ, a self-rated health item from the Medical Outcomes Study, and } \\
\text { the CES-Depression scale. } \\
\text { Others: Self-management behaviour (physical activities scale), Number of visits to physicians during the past } 4 \\
\text { months, Medication use and Self-efficacy. }\end{array}$ \\
\hline Notes & HAQ $=$ Health Assessment Questionnaire \\
\hline
\end{tabular}

\section{Maggs 1996}

Methods A six week, parallel, three group study, with a cross-over after 6 weeks. Co-interventions not allowed.

Assessments were done at baseline and 6 weeks later.

Quality: 0/0/1/0

Participants 162 arthritis patients randomised, 12 drop-outs at first follow-up (5A/5B/2C): 150 analysed (118 RA (36A/ 41B/ 41C); 32 other arthritis). Inclusion: 3 months history of a symptomatic polyarthritis and over the age of $18 \mathrm{yr}$. Exclusion: unable to read English, previous treatment from OT or PT, or need for urgent referral to OT or PT. Mean age: $56.9 \mathrm{yr}$ and $68.7 \%$ female.

Interventions A - Booklet and 30-60 minutes of one-to-one instruction from a health professional (OT) using a standardized script (no practical demonstrations).

C - Routine rheumatology care.

\begin{tabular}{ll} 
Outcomes & $\begin{array}{l}\text { Included: None. } \\
\text { Not reported: VAS-pain, NHP (pain, mobility, emotions), HAQ, Ritchie, ESR. Others: CRP. }\end{array}$ \\
\hline Notes & OT = Occupational therapist \\
& PT $=$ Physiotherapist \\
ADL $=$ Activities of Daily Living \\
NHP = Nottingham Health Profile \\
HAQ = Health Assessment Questionnaire \\
VAS $=$ Visual Analogue Scale \\
ESR $=$ Erythrocyte Sedimentation Rate \\
CRP = C-reactive protein
\end{tabular}

\section{Maggs 1996-B}

\section{Methods}

Participants

Interventions B - Routine care and additionally received a booklet 'Living with Arthritis', with information on RA, energy conservation, joint protection, ADL-exercises, splints and useful addresses.

C - Routine rheumatology care. 
Maggs 1996-B (Continued)

\section{Outcomes}

Notes

\section{Maisiak 1996a}

\begin{tabular}{ll} 
Methods & $\begin{array}{l}\text { A six months, parallel, outcome assessor blinded study. } \\
\text { Assessments were done at baseline and } 6 \text { months later. } \\
\text { Quality: 1/0/2/1 }\end{array}$ \\
\hline Participants & $\begin{array}{l}\text { 58 RA and } 15 \text { SLE-patients, after } 3 \text { drop-outs: } 2 \text { RA, 1 SLE (RA: } 28 \text { exp/30 controls). Inclusion: primary RA or SLE } \\
\text { for at least } 1 \text { yr, capable and willing to be interviewed and counselled over a 6-months period by telephone. Mean } \\
\text { age of the RA-patients: } 53.5 \text { yr and } 100 \% \text { female. }\end{array}$ \\
\hline Interventions & $\begin{array}{l}\text { Counselling: Person-centered, nondirective, telephone based counselling. Sessions every } 4 \text { to } 6 \text { weeks over } 6 \text { months, } \\
\text { initially } 30 \text { minutes, subsequent sessions } 15-30 \text { minutes, using a written, standardized guideline. The protocol } \\
\text { emphasized empathy, positive regard and congruence. } \\
\text { Controls: Usual care. }\end{array}$ \\
\hline Outcomes & $\begin{array}{l}\text { Included: AIMS2 (pain, physical). } \\
\text { Others: AIMS2-psychological (= anxiety + depression + social activities + social interactions). }\end{array}$ \\
\hline Notes & $\begin{array}{l}\text { SLE }=\text { Systemic Lupus Erythematosus } \\
\text { AIMS2 = Arthritis Impact Measurement Scales } 2\end{array}$ \\
\hline
\end{tabular}

\section{Maisiak 1996b}

Methods A 9 month counselling intervention.

Assessments were done at baseline and after 3 (experimental groups only), 6 and 9 (post-test)months.

Quality: 0/1/1/2

Participants 405 arthritis patients randomised (135 each; 219 RA), 26 drop-outs after 9 months (7 TC/11 SM/8 UC): 379 analysed (204 RA: 66 TC/70 SM/68 UC). Inclusion: diagnosis of primary OA-hip or knee or RA; reported current pain or disability due to arthritis; $21 \mathrm{yr}$ or older; able to communicate by phone over a 9 month period; reside in Alabama, USA. Mean age: $60.4 \mathrm{yr}, 92 \%$ female.

Interventions TC - Treatment Counselling: 5 sessions $(20 \mathrm{~min})$ at 2 week intervals during first 3 months and 6 sessions at 4 week intervals during second 6 months, providing patients with a detailed review of their symptoms, including instructions, questions and advice, based on a structured protocol, targeting 6 patient behaviours for potential change: patientphysician communcation, medication compliance, barrieres to medical care, symptoms review, self-care activities, stress control.

UC - Usual Care.

Outcomes Included: AIMS2 (pain, physical, affect).

Notes $\quad$ AIMS $=$ Arthritis Impact Measurement Scales 
Maisiak 1996b-B

\begin{tabular}{l|l}
\hline Methods & \\
\hline Participants & \\
\hline $\begin{array}{l}\text { Interventions } \\
\end{array}$ & $\begin{array}{l}\text { SM - Symptom Monitoring: Similar sessions, without questions or advice, by students with } 2 \text { hr training in the } \\
\text { administration of AIMS2 by phone. } \\
\text { UC - Usual Care. }\end{array}$ \\
\hline Outcomes & \\
\hline Notes & \\
\hline
\end{tabular}

\section{McEvoy-DeVellis 1988}

\begin{tabular}{ll}
\hline Methods & $\begin{array}{l}\text { A } 4 \text { months intervention based on a psychosocial interview. } \\
\text { Assessments were done at baseline and after } 4 \text { months. } \\
\text { Quality: 0/0/1/0 }\end{array}$ \\
\hline Participants & $\begin{array}{l}\text { 126 RA patients recruited (15 refused), } 101 \text { randomised (51 exp/50 contr), } 10 \text { drop-outs (5 exp withdrew before } \\
\text { intervention, } 5 \text { controls lost to follow-up): } 91 \text { analysed (46/45). Inclusion: diagnosis of RA, age } 18 \text { yr or older and } \\
\text { free from significant intellectual deficits. Mean age: } 51.6 \text { yr; } 72 \% \text { female; } 12 \% \text { ARA class 1, 60\% class 2, 27\% class } \\
\text { 3and } 1 \% \text { class } 4 .\end{array}$ \\
\hline Interventions & $\begin{array}{l}\text { All: psychosocial interview to assess problems caused by arthritis and identify actual and potential resources for } \\
\text { coping. } \\
\text { Problem-solving intervention: (1 hr) 1-problem confirmation; 2-identification of alternative strategies; 3-potential } \\
\text { inhibitors; 4-selection of 'best' strategie; 5-action plan; 6-follow-up after 2 weeks by telephone. } \\
\text { Controls: no intervention }\end{array}$ \\
\hline Outcomes & $\begin{array}{l}\text { Included: None. } \\
\text { Not reported: Pain-symptoms, AIMS (pain, dexterity, adl, mobility, physical activity, household activities, depression, } \\
\text { anxiety), Patient global assessment, General Well-Being Scale-depression, Depression-symptoms. } \\
\text { Others: Self-Esteem, AHI. }\end{array}$ \\
\hline Notes & $\begin{array}{l}\text { ARA = American Rheumatism Association } \\
\text { AIMS = Arthritis Impact Measurement Scales } \\
\text { ADL = Activities of Daily Living } \\
\text { AHI = Arthritis Helplessness Index }\end{array}$ \\
\hline
\end{tabular}

\section{Neuberger 1993}

Methods A 16 week self-instructional programme on self-care for individuals with RA. Assessments were done at baseline and after the 16 weeks intervention period. Quality: 0/0/0/0

Participants 98 RA-patients at start; (3 drop-outs, 14 lost to follow-up, 28 still in the programme): 53 analysed (15 A/14 B/13 C/11 D). Inclusion: age 18-76 yr, able to write English and mentally competent. Mean age: 52.56 (sd 14.32), 66\% female. 


\section{Neuberger 1993 (Continued)}

\begin{tabular}{ll} 
Interventions & $\begin{array}{l}\mathrm{A} \text { - same as } \mathrm{B},+ \text { nurse-patient contracts for target behaviours. } \\
\mathrm{D} \text { - non-intervention controls }\end{array}$ \\
\hline Outcomes & Included: VAS-pain, CES-D. \\
\hline Notes & $\begin{array}{l}\text { VAS }=\text { Visual Analogue Scale } \\
\text { CES-D }=\text { Centre for Epidemiologic Studies Depression Scale }\end{array}$ \\
\hline
\end{tabular}

\section{Neuberger 1993-B}

\section{Methods}

\begin{tabular}{ll}
\hline Participants & \\
\hline Interventions & $\begin{array}{l}\text { B - same as C, + practice time: } 10-20 \text { min demonstrations of ROM exercises and tasks using JPPs. } \\
\text { D - non-intervention controls }\end{array}$ \\
\hline Outcomes & \\
\hline Notes & $\begin{array}{l}\text { ROM = Range of Motion } \\
\text { JPPs = Joint Protection Practices }\end{array}$ \\
\hline
\end{tabular}

\section{Neuberger 1993-C}

Methods

\begin{tabular}{ll}
\hline Participants & \\
\hline Interventions & $\begin{array}{l}\text { C - Self-instruction during } 16 \text { weeks, including: What is RA, Medication; Rest, pacing and joint protection; Exercise } \\
\text { and posture. } \\
\text { D - non-intervention controls }\end{array}$ \\
\hline Outcomes & \\
\hline Notes & \\
\hline
\end{tabular}

\section{O’Leary 1988}

Methods A 5 weeks outcome assessor blinded, Cognitive Behavioural treatment for RA patients.

Assessments were done at baseline, after 5 weeks and 4 months after the intervention period.

Quality: 0/0/1/1

Participants 33 RA-patients randomised (17 exp/16 contr); 3 drop-outs (2/1): 30 analysed (15/15). Inclusion: stable medication for 3 months. Exclusion: steroidal medication exceeding $5 \mathrm{mg} /$ day of prednisone. Mean age: $49.3 \mathrm{yr}, 100 \%$ female. 


\section{O’Leary 1988 (Continued)}

\begin{tabular}{ll} 
Interventions & $\begin{array}{l}\text { Cognitive Behavioural treatment: } 5 \text { weekly ( } 2 \mathrm{hr} \text { ) sessions (5-7 people) including self-help book and manual describing } \\
\text { coping techniques. Contents: discussion of biopsychosocial model of pain, training in pain management strategies, } \\
\text { and goal setting with self-reward, telephone 'buddy system' and discussion of communication techniques. } \\
\text { Control treatment: self-help book and information sheet to encourage increased activity. }\end{array}$ \\
\hline Outcomes & $\begin{array}{l}\text { Included: Pain (average pain on three days, } 2 \text { times a day), HAQ, Perceived Stress Scale, Zung Depression Scale. } \\
\text { Not reported: Impaired joints count, ESR. } \\
\text { Others: Pain (highest pain on three days, } 2 \text { times a day), Self-Efficacy (function, pain, other symptoms). }\end{array}$ \\
\hline Notes & HAQ = Health Assessment Questionnaire
\end{tabular}

\section{Oermann 1986}

\begin{tabular}{ll} 
Methods & $\begin{array}{l}\text { A } 5 \text { week, self-instructional education programme. } \\
\text { Assessments were done at baseline and after } 5 \text { weeks. } \\
\text { Quality: 0/0/1/0 }\end{array}$ \\
\hline Participants & $\begin{array}{l}\text { 30 RA patients randomised (15 exp/15 contr), } 3 \text { drop-outs }(0 / 3): 27 \text { analysed (15/12). Inclusion: adults between } \\
18-80 \text { yr, RA, no other rheumatological disease, no hospitalization in past } 3 \text { months, no prior participation in a } \\
\text { structured educational programme on RA. Mean age: } 51.7 \text { yr. }\end{array}$ \\
\hline Interventions & $\begin{array}{l}\text { Self-Instructional Programme: } 7 \text { units, including: disease activity in RA; medications; exercise and rest, joint protec- } \\
\text { tion, work simplification and energy conservation; nutrition and RA; unproven remedies and community resources. } \\
\text { Materials: books, slides and audiotapes, with directions to practice self-care skills and examine routines, situation and } \\
\text { life style. } \\
\text { Controls: no additional treatment }\end{array}$ \\
\hline Outcomes & $\begin{array}{l}\text { Included: None. } \\
\text { Not reported: AIMS (pain, mobility, physical activity, dexterity, adl, impact, depression, anxiety). }\end{array}$ \\
\hline Notes & $\begin{array}{l}\text { AIMS }=\text { Arthritis Impact Measurement Scales } \\
\text { ADL }=\text { Activities of Daily Living }\end{array}$ \\
\hline
\end{tabular}

\section{Parker 1984}

\begin{tabular}{ll} 
Methods & $\begin{array}{l}\text { Inpatient rheumatology care including } 7 \text { hr patient education, with } 3 \text { months follow-up. No co-interventions allowed. } \\
\text { Assessments were done at baseline, immediately after the intervention and } 3 \text { months later. } \\
\text { Quality: 0/0/1/0 }\end{array}$ \\
\hline Participants & $\begin{array}{l}22 \text { male RA-patients (4 drop-outs). Inclusion: willingness to sign a consent form. Exclusion: previous patient educa- } \\
\text { tion, history of organic brain syndrome, presence of major psychotic or uncontrolled medical or major communica- } \\
\text { tion disorder, illiteracy and ARA-class 4. Mean age: } 55.5 \mathrm{yr} \text { (SD: } 10.5), 100 \% \text { male. }\end{array}$
\end{tabular}

Interventions $\quad \mathrm{ED}$-Inpatient rheumatology care plus $7 \mathrm{hr}$ education programme delivered by 2 experienced educators. Including: RA disease process, basic therapies and medication, joint protection and energy conservation, coping with psychosocial stresses and quackery.

$\mathrm{CN}$ - Controls: only inpatient rheumatology care, including occupational therapy and physical therapy. 
Parker 1984 (Continued)

\begin{tabular}{ll}
\hline Outcomes & $\begin{array}{l}\text { Included: None. } \\
\text { Not reported: AIMS (pain, physical activity, dexterity, depression), Beck Depression Inventory. }\end{array}$ \\
\hline Notes & $\begin{array}{l}\text { ARA }=\text { American Rheumatism Association } \\
\text { AIMS }=\text { Arthritis Impact Measurement Scales }\end{array}$ \\
\hline
\end{tabular}

Parker 1988

\begin{tabular}{|c|c|}
\hline Methods & $\begin{array}{l}\text { A } 12 \text { month study, with two control-groups (attention-placebo and non-intervention). } \\
\text { Assessments were done at baseline and after } 6 \text { and } 12 \text { months. } \\
\text { Quality: 1/0/1/0 }\end{array}$ \\
\hline Participants & $\begin{array}{l}84 \mathrm{RA} \text {-patients randomised ( } 29 \mathrm{CB} / 26 \mathrm{AP} / 28 \mathrm{CN}), 1 \text { drop-out }(\mathrm{CN}) \text {. From a Veterans Hospital. Inclusion: classic or } \\
\text { definite RA according to the } 1987 \mathrm{ARA} \text {-criteria. Exclusion: uncontroled medical problems, organic brain syndrome, } \\
\text { major psychiatric disturbances, major communicative disorders, a history of severe non-compliance, less than } 7 \mathrm{yr} \\
\text { formal education, or illiteracy, and functional class } 4 \text {. Mean age } 60.6 \mathrm{yr} \text { (sd: } 7.5) \text {; } 4 \% \text { female; } 7 \% \text { functional class } 1 \text {, } \\
77 \% \text { class } 2 \text { and } 16 \% \text { class } 3 \text {. }\end{array}$ \\
\hline Interventions & $\begin{array}{l}\text { CB - Cognitve-Behavioural group: A pain management programme, beginning with a } 1 \text {-week clinic stay, including } \\
\text { theory on RA and pain and coping strategies. The next } 12 \text { months support group sessions to maintain treatment } \\
\text { gains, on average once every } 2 \text { months. } \\
\text { CN - Control Group: routine care }\end{array}$ \\
\hline Outcomes & $\begin{array}{l}\text { Included: VAS-pain, AIMS (mobility, anxiety, depression, impact), ARA joint count. } \\
\text { Others: McGill Pain Questionnaire, Beck-depression scale, SCL-90-R, Hassles Scale, AHI. }\end{array}$ \\
\hline Notes & $\begin{array}{l}\text { ARA }=\text { American Rheumatology Association } \\
\text { VAS }=\text { Visual Analogue Scale } \\
\text { AIMS = Arthritis Impact Measurement Scales } \\
\text { SCL }=\text { Symptom Checklist-90-Revised } \\
\text { AHI = Arthritis Helplessness Index }\end{array}$ \\
\hline
\end{tabular}

\section{Parker 1988-B}

Methods

\begin{tabular}{ll}
\hline Participants & \\
\hline Interventions & $\begin{array}{l}\text { AP - Attention-Placebo group: A basic RA-education programme (information only), beginning with a 1-week clinic } \\
\text { stay, discussing films and written materials from the Arthritis Foundation. The next } 12 \text { months group sessions, on } \\
\text { average once every } 2 \text { months. } \\
\text { CN - Control Group: routine care }\end{array}$ \\
\hline Outcomes & \\
\hline Notes
\end{tabular}


Parker 1995

\begin{tabular}{ll} 
Methods & $\begin{array}{l}\text { A } 17 \text { months, parallel, outcome assessor blinded study, with three treatment groups. } \\
\text { Assessments were done at baseline, after } 10 \text { weeks and } 3 \text { and } 15 \text { months after the } 10 \text { weeks patient education period. } \\
\text { Quality: 0/1/1/1 }\end{array}$ \\
\hline Participants & $\begin{array}{l}\text { 141 RA patients randomised (45 CN/49 AC/47 SM), } 8 \text { drop-outs at first follow-up (1/4/3): } 133 \text { analysed (44/ } \\
\text { 45/44). Inclusion: classic or definite RA according to the } 1987 \text { ACR-criteria. Exclusion: history of organic brain } \\
\text { syndrome, presence of a psychotic disorder, presence of other uncontrolled medical disorders, presence of a major } \\
\text { communication disorder, and illiteracy. Steinbrocker class } 4 \text { was also excluded. Mean age } 60 \text { yr; } 42.6 \% \text { female; } 21 \% \\
\text { Steinbrocker class } 1,69 \% \text { class } 2 \text { and } 10 \% \text { class } 3 .\end{array}$
\end{tabular}

Interventions $\quad \mathrm{SM}$ - Stress-Management Group: Comprehensive Stress-Management programme, 10 weekly outpatient visits (1.5 hr each) + every 3 months during 15 months maintenance period. Including: relaxation training + instruction in cognitive behavioural strategies for managing typical stressors associated with RA.

CN - Standard Care Control Group.

\begin{tabular}{|c|c|}
\hline Outcomes & $\begin{array}{l}\text { Included: VAS-pain, AIMS (mobility, psychological), ACR-joint counts, STAI-anxiety, CES-D. } \\
\text { Others: MPQ, DSI, HS, AHI, ASES. }\end{array}$ \\
\hline Notes & $\begin{array}{l}\text { VAS = Visual Analogue Scale } \\
\text { MPQ = McGill Pain Questionnaire } \\
\text { AIMS = Arthritis Impact Measurent Scales } \\
\text { ACR = American College of Rheumatology } \\
\text { HS = Hassles Scale } \\
\text { DSI = Daily Stress Inventory } \\
\text { AHI = Arthritis Helplessness Index } \\
\text { CES-D = Centre for Epidemiologic Studies - Depression Scale } \\
\text { STAI = State-Trait Anxiety Inventory } \\
\text { ASES Arthritis Self-efficacy Scales. }\end{array}$ \\
\hline
\end{tabular}

\section{Parker 1995-B}

\begin{tabular}{l|l}
\hline Methods & \\
\hline Participants & \\
\hline Interventions & $\begin{array}{l}\text { AC - Attention-Control Group: } 10 \text { weekly outpatient visits }(1.5 \mathrm{hr} \text { each })+\text { every } 3 \text { months during a period of } 15 \\
\text { months. Computer-assisted educational programme based on materials from the Arthritis Foundation discussed } \\
\text { individually. } \\
\text { CN - Standard Care Control Group. }\end{array}$ \\
\hline Outcomes & \begin{tabular}{l} 
Notes \\
\hline
\end{tabular}
\end{tabular}




\section{Radojevic 1992}

\begin{tabular}{l|l}
\hline Methods & $\begin{array}{l}\text { A } 4 \text { week intervention with } 2 \text { months follow-up. } \\
\text { Assessments were done at baseline, after } 6 \text { weeks and } 2 \text { months later. } \\
\text { Quality: 0/1/1/0 }\end{array}$ \\
\hline Participants & $\begin{array}{l}\text { 65 RA patients recruited, } 6 \text { drop-outs before baseline assessment: } 59 \text { randomised (15 BTFS/14 BT/15 EFS/15 NTC) } \\
\text { and analysed. Inclusion: definite or classical RA. Exclusion: difficulty ambulating due to aging or medical problems } \\
\text { and Class } 4 \text { patients. Mean age: } 54.4 \text { yr, } 76 \% \text { female. }\end{array}$ \\
\hline Interventions & $\begin{array}{l}\text { BTFS - Behaviour Therapy with Family Support: } 4 \text { weekly sessions (90 min, 3-6 patients with family members) } \\
\text { including: gate-control theory of pain and cognitive coping methods; progressive muscle relaxation and diaphragmatic } \\
\text { breathing; and a family component: how RA affects the family, and how the family can assist the patient (N=15, 14 } \\
\text { spouses, } 1 \text { roommate). } \\
\text { NTC: No treatment Controls (N=15, } 13 \text { spouses, } 2 \text { children). }\end{array}$ \\
\hline Outcomes & $\begin{array}{l}\text { Included: AIMS-pain, -functional impairment (=mobility, physical activity, dexterity, household activities and adl), } \\
\text {-psychological status (=anxiety and depression), number of swollen joints, CES-D. } \\
\text { Others: number of painfull joints. }\end{array}$ \\
\hline Notes & $\begin{array}{l}\text { ADL = activities of daily living } \\
\text { CES-D = Centre for Epidemiologic Studies - Depression Scale }\end{array}$ \\
\hline
\end{tabular}

\section{Radojevic 1992-B}

Methods

Participants

Interventions $\quad$ BT - Behaviour Therapy: same as BTFS without family participation and family component $(\mathrm{N}=14 ; 9$ spouses, 4 friends, 1 child)

NTC: No treatment Controls ( $\mathrm{N}=15,13$ spouses, 2 children).

Outcomes

Notes

\section{Radojevic 1992-C}

Methods

Participants

Interventions $\quad$ EFS - Education Family Support: 4 video-taped educational presentations about RA, ranging from medical aspects to physical and emotional effects plus discussion with family members ( $\mathrm{N}=15 ; 12$ spouses, 2 children, 1 roommate) NTC: No treatment Controls ( $\mathrm{N}=15,13$ spouses, 2 children).

Outcomes 
Radojevic 1992-C (Continued)

Notes

Rhodes 1988

Methods A 20 weeks, outcome assessor blinded, group counselling intervention.

Cross-over after 20 weeks.

Assessments were done at baseline, after 10 weeks and after 20 weeks (post-test).

Quality: 0/0/0/1

Participants 48 RA-patients randomised (24 exp/24 contr), 10 drop-outs (4/6): 38 analysed (20/18). Inclusion: RA according to ARA-criteria; at least 2 clinically active joints plus 1 out of 4: morning stiffness, diminished grip strength, elevated sedimentation or positive latex fixation test. Mean age: $45.45,97 \%$ female.

Interventions Counselling: 20 weekly ( $4 \mathrm{hr}$ ) group sessions ( 12 persons) led by a peer-patient therapist and professional co-therapist. Including: education, cognitive awareness training, biofeedback, relaxation training, guided imagery and decision making.

Controls: Waiting list controls

Outcomes Included: VAS-pain; McMaster Health Questionnaire (disability, emotion).

Not reported: McMaster Health Questionnaire (affect), Ritchie Articular Index, ESR.

Others: Locus of Control, Personal Orientation Inventory.

Notes $\quad$ VAS $=$ Visual Analogue Scale

$\mathrm{ESR}=$ Erythrocyte Sedimentation Rate

\section{Riemsma 1999}

Methods A 12 months group education study, with and without partners, including 3 booster sessions. Assessments were done at baseline and after 2, 6 and 12 months.

Quality: 0/0/2/1

Participants 238 RA-patients randomised (79 GEP/80 GE/79 C), 20 drop-outs at baseline (8/9/3), 37 drop-outs at final followup (17/14/6). Inclusion: Outpatients satisfying at least 4 of the 1987 ACR-criteria for RA, with a significant other willing to participate, and age between 20 and $70 \mathrm{yr}$. Exclusion: residence in a nursing home.

Mean age: 56.4 yr (SD: 9.6); disease duration: 11.7 yr (SD: 9.8), 62\% female.

Interventions Group Education With Partner (GEP): 5 weekly (2 hr) group sessions (6-8 patients) with partner, led by two health professionals. Including: contracting, goalsetting and feedback; self-management and problem-solving; information on RA and treatment; pain management and relaxation; physical exercises; communication skills; coping with depression. Booster sessions after 3,6 and 9 months repeating the topics from the first 5 sessions.

Controls (C): No additional intervention.

Outcomes Included: Dutch-AIMS2 (pain, physical, affect, mood and stress), Ritchie Articular Index, Patient global assessment (VAS), ESR. 


\begin{tabular}{ll}
\hline Notes & ACR $=$ American College of Rheumatology \\
& VAS $=$ Visual Analogue Scale \\
& ESR $=$ Erythrocyte Sedimentation Rate \\
\hline
\end{tabular}

\section{Riemsma 1999-B}

\begin{tabular}{l|l}
\hline Methods & \\
\hline Participants & \\
\hline Interventions & $\begin{array}{l}\text { Group Education Without Partner (GE): Same as GEP, without partner. } \\
\text { Controls (C): No additional intervention. }\end{array}$ \\
\hline Outcomes & \\
\hline Notes & \\
\hline
\end{tabular}

\section{Rodriguez 1996}

Methods A 9 months Randomised Controlled Trial.

Assessments were done at baseline and after 9 months.

Quality: 0/1/1/0

Participants 50 RA-patients (no in- or exclusion criteria mentioned)

Interventions Patient Education: Minimal 1 individual visit $(1 \mathrm{hr})$ to a nursein the clinic during first three weeks. Contents: 1 explanation of RA; 2-explanation of physical therapies (heat packs, exercises, rest, joint protection); 3-explanation of drugs and side effects. Second (or more) visits weekly up to 3 months if necessary.

Controls: usual treatment.

Outcomes Included: VAS-pain, HAQ, Ritchie Articular Index.

Others: number of painfull joints, number of inflamed joints, morning stifness, ACR criteria.

$\begin{array}{ll}\text { Notes } & \text { ACR }=\text { American College of Rheumatology } \\ \mathrm{HAQ}=\text { Health Assessment Questionnaire } \\ \text { VAS }=\text { Visual Analogue Scale }\end{array}$

\section{Savelkoul 2001}

Methods 13 week Randomised Controlled Trial, with 6 month follow-up.
Assessments were done at baseline, after 13 weeks and after 6 months.
Quality: $2 / 1 / 2 / 2$

Participants 183 arthritis patients randomised, 15 withdrew after randomisation but before first meassurement. Analysis on 168 patients (56 CIG/56 MSCG/56 WLCG), including 104 RA patients (35/35/34). Inclusion: at least one chronic rheumatic disorder affecting the joints, disease duation > i yr, age: 35-65 yr, higher than median score on loneliness, lack of social support, impact of rheumatic disease on functional health status in general or on social behaviour 


\section{Savelkoul 2001 (Continued)}

specifically. Exclusion: fybromyalgia.

Mean age: 51.95 yr (SD: 8.36), 75\% female, disease duration: 154.66 months (SD: 127.07).

Interventions CIG: 10 sessions: 8 weekly sessions ( 2 hr, 10-12 patients), 9th session 2 weeks later, 10th session 3 weeks thereafter; led by a therapist experienced in behavioral therapy assisted by a nurse or social worker; contents: teaching actiondirected coping and coping by seeking social support; problem-solving techniques and exercises at home.

WLCG: usual care, after follow-up control patients received an invitation for MSCG.

Outcomes Included: SIP-disability (somatic autonomy, mobility control, mobility range), SIP-psychological status (psychological autonomy and communication, emotional stability), SIP-anxiety (psychological autonomy and communication) , SIP-depression (emotional stability), patient global assessment.

Others: Coping, social support, loneliness, quality of life.

\begin{tabular}{l|l} 
Notes & CIG $=$ Coping intervention Group \\
MSCG $=$ Mutual Support Control Group \\
WLCG = WAiting List Control Group \\
SIP = Sickness Impact Profile
\end{tabular}

\section{Savelkoul 2001-B}

Methods

\begin{tabular}{ll}
\hline Participants & \\
\hline $\begin{array}{l}\text { Interventions } \\
\text { MSCG: same sessions led by } 2 \text { patients trained in supervising mutual support groups; the supervisor's role was to } \\
\text { facilitate interaction. } \\
\text { WLCG: usual care, after follow-up control patients received an invitation for MSCG. }\end{array}$ \\
\hline Outcomes & \\
\hline Notes & \\
\hline
\end{tabular}

\section{Scholten 1999}

Methods A one-year prospective randomised trial for one year, with a waiting list control group, who received education after one year.

Assessments were done at baseline, 2 weeks later (post-treatment), 6 weeks later, and 52 weeks later.

Quality: $1 / 1 / 2 / 2$

Participants 70 consecutive were recruited and randomised (I: 38; C: 32).

"68 consecutive patients with definitive RA (1987 revised ARA criteria) participated in an arthritis training programme, either immediately after enrolment or after one year".

68 patients analysed (I: 38; C: 30). Inclusion: patients with definitive RA (1987 revised ARA criteria).

Mean age: 48.3 years (SD: 5.6), range: $21-79$ years, $79 \%(n=54)$ female. Disease duration: 8.9 years (SD: 1.2, range: 0.4-30 years). 14 patients had functional class I; 38 patients had functional class II; and 17 patients had functional class III. 
Scholten 1999 (Continued)

\begin{tabular}{ll} 
Interventions & $\begin{array}{l}\text { Intervention: A 9-day programme (9 afternoons within } 2 \text { weeks) for } 8 \text { patients, voluntarily accompanied by relatives } \\
\text { or friends, encompassing a multidisciplinary co-operation between rheumatologists, orthopedists, physicotherapists, } \\
\text { psychologists and social workers. The programme covered the following fields: pathogenesis of RA, benefits and } \\
\text { limitations of drug therapy, the impact of physicotherapy, practical exercise in remedial gymnastics, use of joint } \\
\text { protection devices, orthopedic perspectives, psychological counselling, dietetics, information about unproven cures } \\
\text { and social assistance. The teaching professionals integrated theory with practice. This strategy encouraged patients } \\
\text { to practice the techniques they were taught; it involved interactive discussion, problem solving, and goal-setting and } \\
\text { sought to improve compliance through the use of diaries. Patients received a published information booklet, based } \\
\text { on Lorig's 'Arthritis Helpbook', covering the contents of the training programme. } \\
\text { Controls: waiting list control group. }\end{array}$ \\
\hline Outcomes & $\begin{array}{l}\text { Included: HAQ and Beck Depression Inventory. } \\
\text { Others: Freiburg Questionnaire of Coping with Illness, and a 21-point scale to evaluate cognitive-behavioural and } \\
\text { environmental impact. }\end{array}$ \\
\hline ARA $=$ American Rheumatism Association \\
HAQ = Health Assessment Questionnaire
\end{tabular}

\section{Sharpe 2001}

Methods An 18-months randomised controlled trial comparing routine medical management plus a cognitive behavioural intervention with routine medical management. The intervention took place during an 8-week period.

Assessments were done at baseline, after 8 weeks (post-treatment), 6 months and 18 months.

Quality: 2/0/2/1

Participants The sample was drawn from rheumatology clinics, 63 patients met the entry criteria of whom 56 (88\%) agreed to take part. 53 entered the study and were randomised (I: 27; C: 26). 45 patients analysed (I: 23; C: 22). Inclusion: A diagnosis of classical or definite RA, seropositive and less than 2 years of disease history. Age between 18 and 75 years. Patients with a known history of mental illness or alcohol or drug abuse were excluded, as were those with insufficient command of English to complete the assessment and participate in the intervention. Mean age: 55.06 years (SD: 14.07), 70\% female. Mean disease duration: 12.63 months (SD: 8.22). 67\% took some combination of disease modifying drugs and non-steroidal anti-inflammatories. $10 \%$ took disease modifying drugs only, $6 \%$ were taking non-steroidal anti-inflammatories and $13 \%$ were taking steroids only.

Interventions Intervention: Routine medical management plus an adjunct psychological intervention, conducted by 2 psychologists, according to a treatment manual developed specifically for the project. The programme involved 8 individual therapist-client sessions, each lasting around 1-hour over an 8-week period. The cognitive and behavioural intervention was developed from standard pain management approaches and self-help educational material developed for patient with arthritis. The programme included an educational component plus the following self-management skills: relaxation training, attention diversion, goal setting, pacing, problem-solving, cognitive restructuring, assertiveness and communication, and management of flare-ups or high-risk situations.

Controls: Routine medical management.

Outcomes Included: Self-monitored level of subjective pain, Health Assessment Questionnaire (HAQ), Ritchie Articular Index, Hospital Anxiety and Depression Scale (HAD), and ESR.

Others: Coping strategy Questionnaire, and CRP. 


\section{Sharpe 2001 (Continued)}

\begin{tabular}{ll}
\hline Notes & ESR $=$ Erythrocyte Sedimentation Rate \\
& $\mathrm{CRP}=$ C-reactive protein \\
\hline
\end{tabular}

\section{Shearn 1985}

\begin{tabular}{ll} 
Methods & $\begin{array}{l}\text { A } 10 \text { weeks intervention, with } 8 \text { months follow-up. } \\
\text { Assessments were done at baseline, after the } 8 \text { weeks intervention period and } 8 \text { months later. } \\
\text { Quality: 0/0/0/0 }\end{array}$ \\
\hline Participants & $\begin{array}{l}\text { 105 RA patients randomised (35 SM/35 MS/35 C). } 24 \text { drop-outs at post-test }(9 / 10 / 5), 35 \% \text { respons at } 8 \text { months } \\
(\mathrm{N}=37) . \\
\text { Inclusion: English speaking RA patients according to } 1987 \text { ARA-criteria. Mean age } 56 \mathrm{yr}, 75 \% \text { female. }\end{array}$ \\
\hline Interventions & $\begin{array}{l}\text { SM - Self-Management: } 10 \text { weekly }(90 \text { min) sessions, led by psychologist. Aimed to help patients identify sources of } \\
\text { stress, learn relaxation techniques and strategies for coping. } \\
\text { CN - Controls: no intervention. }\end{array}$ \\
\hline Outcomes & $\begin{array}{l}\text { Included: VAS-pain, Health Assessment Questionnaire, Ritchie Articular Index, CES-D, Erythrocyte Sedimentation } \\
\text { Rate. }\end{array}$ \\
\hline Notes & $\begin{array}{l}\text { ARA }=\text { American Rheumatism Association. } \\
\text { VAS }=\text { Visual Analogue Scale }\end{array}$ \\
& CES-D = Centre for Epidemiologic Studies - Depression Scale
\end{tabular}

\section{Shearn 1985-B}

\begin{tabular}{l|l}
\hline Methods & \\
\hline Participants & \\
\hline Interventions & $\begin{array}{l}\text { MS - Mutual Support: Same sessions. Aimed to enhance self-responsibility, exchange information, build relationships } \\
\text { and attempt to decrease social isolation. } \\
\text { CN - Controls: no intervention. }\end{array}$ \\
\hline Outcomes & \\
\hline Notes & \\
\hline
\end{tabular}

\section{Stenstrom 1994}

Methods A 24-weeks parallel, outcome assessor blinded study.

Assessments were done 12 weeks before baseline, at baseline and 12 weeks after baseline (only the last 2 assessments were included in the analyses).

Quality: 0/0/1/1 


\section{Stenstrom 1994 (Continued)}
Participants 48 RA-patients recruited, 5 were excluded and 1 drop-out before randomisation: 42 randomised (22 CT/20 PA), 2 drop-outs after randomisation (CT): 40 analysed (20/20). Inclusion: RA according to the 1987 ARA-criteria, age below $70 \mathrm{yr}$, ARA functional class 2 and willingness to participate. Mean age $55 \mathrm{yr}$ (SD: 8) and 70\% female.

\begin{tabular}{|c|c|}
\hline Interventions & $\begin{array}{l}\text { All: personal exercise instructions by PT }+ \text { written and taped instructions with music for home exercises. } 5 \text { days a } \\
\text { week during } 12 \text { weeks: exercises using a } 1.40 \text { m rubber strip with tied loops at bottom ends for strengthening and } \\
\text { a shoulder pulley apparatus for mobility exercises in upper and lower extremities, for stretching and walking, }+12 \\
\text { weeks follow-up period: } \\
\text { CT - Cognitive Treatment: goal-setting and reinterpretation of activity induced pain. Patient and PT decided an } \\
\text { increased load as a goal and patients were encouraged to increase walking speed. } \\
\text { PA - Pain Attention control group: materials to increase load of exercise were available on request, but no specific } \\
\text { goals or encouragements. }\end{array}$ \\
\hline Outcomes & $\begin{array}{l}\text { Included: HAQ, Ritchie Articular Index. } \\
\text { Others: Self-Efficacy RA. }\end{array}$ \\
\hline Notes & $\begin{array}{l}\text { ARA = American Rheumatology Association } \\
\text { PT = Physiotherapist } \\
\text { HAQ = Health Assessment Questionnaire }\end{array}$ \\
\hline
\end{tabular}

\section{Strauss 1986}

\begin{tabular}{ll} 
Methods & $\begin{array}{l}\text { A } 1 \text { year parallel study. } \\
\text { Assessments were done at baseline and after 3,6 and } 12 \text { months. } \\
\text { Quality: 0/0/0/0 }\end{array}$ \\
\hline Participants & $\begin{array}{l}\text { 57 RA patients randomised (20 PT/17 ART/20 CG), } 12 \text { drop-outs (6/6/0) at post-test (PT: } 6 \text { months; ART: } 3 \\
\text { months) and one more (PT) at } 1 \text { yr follow-up. Inclusion: classic or definite RA by ARA criteria, ability to speak } \\
\text { English, outpatient status, and able to attend a weekly group at the medical centre. Mean age: } 54 \text { yr, } 81 \% \text { female. }\end{array}$ \\
\hline Interventions & $\begin{array}{l}\text { ART - Assertion/Relaxation Training: weekly structured meetings for } 3 \text { months with role-playing of assertive be- } \\
\text { haviour; relaxation exercises were taught and audiotapes for home practice. } \\
\text { CG: Control Group - no treatment. }\end{array}$ \\
\hline Outcomes & $\begin{array}{l}\text { Included: None. } \\
\text { Not reported: AIMS-functional status (mobility, physical actvity, household activities, self-care). } \\
\text { Others: AIMS-psychological symptoms (anxiety, depression, pain). }\end{array}$ \\
\hline Notes & $\begin{array}{l}\text { ARA }=\text { American Rheumatology Association } \\
\text { AIMS }=\text { Arthritis Impact Measurement Scales }\end{array}$ \\
\hline
\end{tabular}

\section{Strauss 1986-B}

Methods

Participants 


\section{Strauss 1986-B (Continued)}

\begin{tabular}{l|l} 
Interventions & $\begin{array}{l}\text { PT - Psycho-therapy group: weekly meetings for } 6 \text { months (10 persons) emphasising mutual support through sharing } \\
\text { of experiences and emotions related to RA. Led by pairs of senior psychiatric residents with group experience. } \\
\text { CG: Control Group - no treatment. }\end{array}$ \\
\hline Outcomes & \\
\hline Notes & \\
\hline
\end{tabular}

Taal 1993

\begin{tabular}{ll} 
Methods & $\begin{array}{l}\text { A } 15 \text { months, parallel group education programme. } \\
\text { Assessments were done at baseline, after } 6 \text { weeks and after } 4 \text { and } 14 \text { months. } \\
\text { Quality: 1/0/0/1 }\end{array}$ \\
\hline Participants & $\begin{array}{l}\text { 75 RA-patients randomised (38 exp/37 contr), } 13 \text { drop-outs and } 5 \text { non-attendants: } 57 \text { analysed (27/30). Inclusion: } \\
\text { diagnosis of RA according to } 1987 \text { ARA-criteria, age between } 21 \text { and } 65 \text { yr, maximum use of } 8 \text { yr of second-line } \\
\text { medication. Mean age: } 49.6 \text { yr and } 74 \% \text { female. } 13 \text { patients functional class } 1,41 \text { class } 2 \text { and } 3 \text { class } 3 .\end{array}$ \\
\hline Interventions & $\begin{array}{l}\text { Group Education: } 5 \text { weekly (2 hr) group sessions (6-8 patients) if preferred with partner, led by two health profes- } \\
\text { sionals. Including: contracting, goalsetting and feedback; self-management and problem-solving; information on RA } \\
\text { and treatment; pain management and relaxation; physical exercises; communication skills; coping with depression. } \\
\text { Controls: no intervention. }\end{array}$ \\
\hline Outcomes & $\begin{array}{l}\text { Included: Dutch-AIMS (pain, anxiety, depression, arthritis impact), M-HAQ, Ritchie Articular Index, ESR. } \\
\text { Others: Dutch-AIMS (mobility, physical activity, dexterity, household activities, activities of daily living), Self-Efficacy } \\
\text { (self-management, pain, function, other symptoms). }\end{array}$ \\
\hline Notes & $\begin{array}{l}\text { ARA = American Rheumatology Association } \\
\text { AIMS = Arthritis Impact Measurement Scales } \\
\text { M-HAQ = Modified Health Assessment Questionnaire } \\
\text { ESR = erythrocyte sedimentation rate }\end{array}$ \\
\hline
\end{tabular}

\section{Wetstone 1985}

Methods A 6 week, assessor blinded, computer based education lesson. Assessments were done at baseline and after 6 weeks. Quality: 0/0/1/1

Participants $36 \mathrm{RA}$ patient randomised (18 CBE/18 Contr), 1 drop-out (contr). Inclusion: classical or definite RA from 5 months to 20 yr. Mean age: $50.9,83 \%$ female.

Interventions CBE: Computer based Education lesson at home. Patients received 5-10 min instruction and completed the lesson in 1-4 sessions, on average 107 min. Topics: arthritis; nature of RA; causes and cures; diagnosis; treatment; medication; rest, energy conservation, joint protection; exercise; quackery; diet and climate; quiz.

Controls: no intervention. 
Wetstone 1985 (Continued)

\begin{tabular}{l|l} 
Outcomes & $\begin{array}{l}\text { Included: None. } \\
\text { Not reported: Affect Balance Scale (positive affect/ negative affect). } \\
\text { Others: Health Locus of Control. }\end{array}$ \\
\hline Notes & \\
\hline
\end{tabular}

\section{Characteristics of excluded studies [ordered by study ID]}

Darmawan 1992 Outcome measures do not include any from our set of outcome measures.
Method: RCT
Participants: 443 exp/401 contr. 4683 inhabitants from two rural villages were interviewed, 844 from 1105
respondents with musculoskeletal pain were randomly selected for the programme. Groups were matched on
age, sex and educational level and an attempt was made to stratify cases based on location of rheumatic pain.
Intervention: The intervention group attended a special session of the puppet play which included simple
instructions for coping with neck and back pain, and deformed, stiff, swollen or painful joint(s). The importance
of this special session was explained to the puppeteer who was able to control the mood of the audiance through
the puppets with an improvised dialogue interwoven into a fragment of one of the popular Hindu epics.
Controls: usual treatment (not mentioned). Respondents were interviewed before and one and six months after
the intervention.
Outcomes: Knowledge of how to perform ADL-tasks.

Feinberg 1992 Outcome measures do not include any from our set of outcome measures.

Method: A 1-month Randomized Controlled Trial.

Participants: 40 RA-patients (20 exp/20 controls) who were referred for provision of resting hand splints. Intervention: A compliance-enhancement group: one session emphasizing the use of learning principles, sharing of expectations, use of a positive affective tone and behaviours by the therapist, and the asssumption of responsability by the patient and a telephone check-up 2 weeks after splinting; and a standard treatment control group.

Outcomes: compliance with splint use, wrist and hand pain and duration of morning stiffness.

Linne $2001 \quad$ Outcome measures do not include any from our set of outcome measures. Method: RCT

Participants: Patients treated for rheumatological diseases at the Dept of Rheumatology at the University Hospital of Malmo and by rheumatology specialists at cooperating out-patient clinics in the cities of Malmo and Trelleborg were eligible if they were regularly treated with daily doses of NSAIDs and diuretic drugs; 48 RA-patients (18 exp/30 controls) were randomised out of 72 eligible patients.

Intervention: Patients in the experimental group received oral information from the pharmacist on diuretic, analgesic and anti-inflammatory drugs, and non-commercial leaflets with the same information. The main part of the information consisted of an interactive CD programme, in which patients trained their knowledge. Control patients received non-systematic, conventional information during hospitalisation and/or at regular control visits.

Outcomes: knowledge regarding diuretic, analgesic and anti-inflammatory drugs. 


\begin{tabular}{ll} 
Pope 1998 & Outcome measures do not include any from our set of outcome measures. \\
Method: RCT \\
Participants: All patients attending the rheumatology followup clinic and expected for a further followup visit \\
were eligible; 71 RA-patients $(34 \mathrm{exp} / 37$ controls) participated after one dropout. \\
$\begin{array}{l}\text { Intervention: All patient were given verbal information about the particular NSAID that they were taking. } \\
\text { Patients in the experimental group then received a drug information sheet, including far more detail with respect } \\
\text { tothe indications for and the side effects of NSAID. } \\
\text { Outcomes: knowledge about NSAID use. }\end{array}$ \\
\hline Sebro 1993 & Not retrieved. \\
\hline
\end{tabular}

Van Deussen 1987 Outcome measures do not include any from our set of outcome measures.

Method: A 6-month cross-over study.

Participants: 46 RA-patients ( $23 \mathrm{exp} / 23$ controls) who had medical recomendations for home rest and exercise, with voluntary cross-over.

Intervention: ROM-dance programme: 8, 90-minutes, weekly health education classes with 15-25 participants. Including: Range-of-Motion (ROM)-dance sequence, a guided relaxation experience and a group discussion. Control group: Waiting list controls.

Outcomes: Exercise-rest rating scales to asses frequency, benefits and enjoyment of exercise and joint ranges.

Young 1995 In this report only effects on health care resources reported.

Same study as Bradley et al., 1987 \& 1988:

- Bradley LA, Young LD, Anderson KO, Turner RA, Agudelo CA, McDaniel LK, Pisko E, Semble EL, Morgan TM. Effects of psychological therapy on pain behavior of rheumatoid arthritis patients. Treatment outcome and six-month follow-up. Arthritis Rheum. 1987 Oct; 30(10): 1105-1114.

- Bradley LE, Young LD, Anderson KO, Turner RA, Agudelo CA, McDaniel LK, Semble EL. Effects of cognitive-behavioral therapy on rheumatoid arthritis pain behavior: one-year follow-up. In: Dubner R, Gebhart GF, Bond MR (Eds.): Proceedings of the Vth World Congress on Pain (pp 310-314). Elsevier Publishers, 1988. 
DATA AND ANALYSES

Comparison 1. Patient Education versus Controls

\begin{tabular}{|c|c|c|c|c|}
\hline Outcome or subgroup title & $\begin{array}{l}\text { No. of } \\
\text { studies }\end{array}$ & $\begin{array}{c}\text { No. of } \\
\text { participants }\end{array}$ & Statistical method & Effect size \\
\hline 1 Pain & 39 & & Std. Mean Difference (IV, Fixed, 95\% CI) & Subtotals only \\
\hline 1.1 post-treatment results & 37 & 2219 & Std. Mean Difference (IV, Fixed, 95\% CI) & $-0.08[-0.16,0.00]$ \\
\hline 1.2 final follow-up & 19 & 1073 & Std. Mean Difference (IV, Fixed, 95\% CI) & $-0.07[-0.19,0.05]$ \\
\hline 2 Disability & 38 & & Std. Mean Difference (IV, Fixed, 95\% CI) & Subtotals only \\
\hline 2.1 post-treatment results & 37 & 2275 & Std. Mean Difference (IV, Fixed, 95\% CI) & $-0.17[-0.25,-0.09]$ \\
\hline 2.2 final follow-up & 23 & 1308 & Std. Mean Difference (IV, Fixed, 95\% CI) & $-0.09[-0.20,0.02]$ \\
\hline 3 Joint Counts & 26 & & Std. Mean Difference (IV, Random, 95\% CI) & Subtotals only \\
\hline 3.1 post-treatment results & 23 & 1158 & Std. Mean Difference (IV, Random, 95\% CI) & $-0.13[-0.24,-0.01]$ \\
\hline 3.2 final follow-up & 16 & 974 & Std. Mean Difference (IV, Random, 95\% CI) & $-0.08[-0.22,0.07]$ \\
\hline 4 Patient Global Assessment & 9 & & Std. Mean Difference (IV, Fixed, 95\% CI) & Subtotals only \\
\hline 4.1 post-treatment results & 6 & 358 & Std. Mean Difference (IV, Fixed, 95\% CI) & $-0.28[-0.49,-0.07]$ \\
\hline 4.2 final follow-up & 8 & 618 & Std. Mean Difference (IV, Fixed, 95\% CI) & $-0.06[-0.22,0.10]$ \\
\hline 5 Physician Global Assessment & 0 & & Std. Mean Difference (IV, Fixed, 95\% CI) & Subtotals only \\
\hline 5.1 post-treatment results & 0 & 0 & Std. Mean Difference (IV, Fixed, 95\% CI) & Not estimable \\
\hline 5.2 final follow-up & 0 & 0 & Std. Mean Difference (IV, Fixed, 95\% CI) & Not estimable \\
\hline 6 Psychological Status & 19 & & Std. Mean Difference (IV, Fixed, 95\% CI) & Subtotals only \\
\hline 6.1 post-treatment results & 18 & 1138 & Std. Mean Difference (IV, Fixed, 95\% CI) & $-0.15[-0.27,-0.04]$ \\
\hline 6.2 final follow-up & 13 & 794 & Std. Mean Difference (IV, Fixed, 95\% CI) & $0.04[-0.10,0.19]$ \\
\hline 7 Anxiety & 19 & & Std. Mean Difference (IV, Fixed, 95\% CI) & Subtotals only \\
\hline 7.1 post-treatment results & 18 & 1328 & Std. Mean Difference (IV, Fixed, 95\% CI) & $-0.04[-0.15,0.07]$ \\
\hline 7.2 final follow-up & 16 & 990 & Std. Mean Difference (IV, Fixed, 95\% CI) & $0.01[-0.12,0.13]$ \\
\hline 8 Depression & 30 & & Std. Mean Difference (IV, Fixed, 95\% CI) & Subtotals only \\
\hline 8.1 post-treatment results & 29 & 1770 & Std. Mean Difference (IV, Fixed, 95\% CI) & $-0.14[-0.23,-0.05]$ \\
\hline 8.2 final follow-up & 20 & 1143 & Std. Mean Difference (IV, Fixed, 95\% CI) & $-0.09[-0.21,0.02]$ \\
\hline 9 Disease Activity & 18 & & Std. Mean Difference (IV, Fixed, 95\% CI) & Subtotals only \\
\hline 9.1 post-treatment results & 15 & 647 & Std. Mean Difference (IV, Fixed, 95\% CI) & $-0.03[-0.19,0.12]$ \\
\hline 9.2 final follow-up & 11 & 718 & Std. Mean Difference (IV, Fixed, 95\% CI) & $-0.05[-0.20,0.10]$ \\
\hline
\end{tabular}

Comparison 2. Information Only versus Controls

\begin{tabular}{|c|c|c|c|c|}
\hline Outcome or subgroup title & $\begin{array}{l}\text { No. of } \\
\text { studies }\end{array}$ & $\begin{array}{c}\text { No. of } \\
\text { participants }\end{array}$ & Statistical method & Effect size \\
\hline 1 Pain & 9 & & Std. Mean Difference (IV, Fixed, 95\% CI) & Subtotals only \\
\hline 1.1 post-treatment results & 8 & 524 & Std. Mean Difference (IV, Fixed, 95\% CI) & $-0.15[-0.32,0.02]$ \\
\hline 1.2 final follow-up & 4 & 232 & Std. Mean Difference (IV, Fixed, 95\% CI) & $0.05[-0.21,0.31]$ \\
\hline 2 Disability & 6 & & Std. Mean Difference (IV, Fixed, 95\% CI) & Subtotals only \\
\hline 2.1 post-treatment results & 6 & 432 & Std. Mean Difference (IV, Fixed, 95\% CI) & $-0.02[-0.21,0.17]$ \\
\hline 2.2 final follow-up & 4 & 236 & Std. Mean Difference (IV, Fixed, 95\% CI) & $-0.01[-0.27,0.25]$ \\
\hline 3 Joint Counts & 6 & & Std. Mean Difference (IV, Fixed, 95\% CI) & Subtotals only \\
\hline 3.1 post-treament results & 6 & 356 & Std. Mean Difference (IV, Fixed, 95\% CI) & $-0.14[-0.35,0.07]$ \\
\hline
\end{tabular}

Patient education for adults with rheumatoid arthritis (Review)

Copyright (C) 2009 The Cochrane Collaboration. Published by John Wiley \& Sons, Ltd. 


$\begin{array}{lll}\text { 3.2 final follow-up } & 4 & 23 \\ \text { 4 Patient Global Assessment } & 2 & \\ \text { 4.1 post-treatment results } & 1 & 54 \\ \text { 4.2 final follow-up } & 2 & 12 \\ \text { 5 Physician Global Assessment } & 0 & \\ \text { 5.1 post-treatment results } & 0 & 0 \\ \text { 5.2 final follow-up } & 0 & 0 \\ \text { 6 Psychological Status } & 4 & \\ \text { 6.1 post-treatment results } & 3 & 25 \\ \text { 6.2 final follow-up } & 3 & 17 \\ \text { 7 Anxiety } & 3 & \\ \text { 7.1 post-treatment results } & 3 & 22 \\ \text { 7.2 final follow-up } & 2 & 13 \\ \text { 8 Depression } & 5 & \\ \text { 8.1 post-treatment results } & 5 & 28 \\ \text { 8.2 final follow-up } & 3 & 16 \\ \text { 9 Disease Activity } & 3 & \\ \text { 9.1 post-treatment results } & 3 & 186 \\ \text { 9.2 final follow-up } & 2 & 12\end{array}$

237 Std. Mean Difference (IV, Fixed, 95\% CI) Std. Mean Difference (IV, Fixed, 95\% CI) 54 Std. Mean Difference (IV, Fixed, 95\% CI) 126 Std. Mean Difference (IV, Fixed, 95\% CI) Std. Mean Difference (IV, Fixed, 95\% CI) $0 \quad$ Std. Mean Difference (IV, Fixed, 95\% CI) $0 \quad$ Std. Mean Difference (IV, Fixed, 95\% CI) Std. Mean Difference (IV, Fixed, 95\% CI) Std. Mean Difference (IV, Fixed, 95\% CI) Std. Mean Difference (IV, Fixed, 95\% CI) Std. Mean Difference (IV, Fixed, 95\% CI) Std. Mean Difference (IV, Fixed, 95\% CI) Std. Mean Difference (IV, Fixed, 95\% CI) Std. Mean Difference (IV, Fixed, 95\% CI) Std. Mean Difference (IV, Fixed, 95\% CI) Std. Mean Difference (IV, Fixed, 95\% CI) Std. Mean Difference (IV, Fixed, 95\% CI) Std. Mean Difference (IV, Fixed, 95\% CI) Std. Mean Difference (IV, Fixed, 95\% CI)
$0.02[-0.24,0.27]$

Subtotals only $-0.21[-0.75,0.32]$ $-0.20[-0.55,0.16]$ Subtotals only Not estimable Not estimable Subtotals only $-0.24[-0.48,0.01]$ $-0.07[-0.37,0.23]$ Subtotals only $0.05[-0.21,0.31]$ $-0.02[-0.36,0.32]$ Subtotals only $-0.10[-0.34,0.13]$ $0.01[-0.30,0.31]$ Subtotals only $0.14[-0.15,0.43]$ $0.22[-0.13,0.58]$

Comparison 3. Counselling versus Controls

\begin{tabular}{|c|c|c|c|c|}
\hline Outcome or subgroup title & $\begin{array}{l}\text { No. of } \\
\text { studies }\end{array}$ & $\begin{array}{c}\text { No. of } \\
\text { participants }\end{array}$ & Statistical method & Effect size \\
\hline 1 Pain & 3 & & Std. Mean Difference (IV, Fixed, 95\% CI) & Subtotals only \\
\hline 1.1 post-treatment results & 3 & 242 & Std. Mean Difference (IV, Fixed, 95\% CI) & $0.13[-0.13,0.38]$ \\
\hline 1.2 final follow-up & 0 & 0 & Std. Mean Difference (IV, Fixed, 95\% CI) & Not estimable \\
\hline 2 Disability & 4 & & Std. Mean Difference (IV, Fixed, 95\% CI) & Subtotals only \\
\hline 2.1 post-treatment results & 4 & 311 & Std. Mean Difference (IV, Fixed, 95\% CI) & $-0.15[-0.37,0.08]$ \\
\hline 2.2 final follow-up & 1 & 69 & Std. Mean Difference (IV, Fixed, 95\% CI) & $-0.03[-0.50,0.44]$ \\
\hline 3 Joint Counts & 1 & & Std. Mean Difference (IV, Fixed, 95\% CI) & Subtotals only \\
\hline 3.1 post-treatment results & 1 & 51 & Std. Mean Difference (IV, Fixed, 95\% CI) & $-0.31[-0.87,0.24]$ \\
\hline 3.2 final follow-up & 0 & 0 & Std. Mean Difference (IV, Fixed, 95\% CI) & Not estimable \\
\hline 4 Patient Global Assessment & 1 & & Std. Mean Difference (IV, Fixed, 95\% CI) & Subtotals only \\
\hline 4.1 post-treatment results & 1 & 68 & Std. Mean Difference (IV, Fixed, 95\% CI) & $-0.29[-0.77,0.19]$ \\
\hline 4.2 final follow-up & 1 & 68 & Std. Mean Difference (IV, Fixed, 95\% CI) & $0.23[-0.24,0.71]$ \\
\hline 5 Physician Global Assessment & 0 & & Std. Mean Difference (IV, Fixed, 95\% CI) & Subtotals only \\
\hline 5.1 post-treatment results & 0 & 0 & Std. Mean Difference (IV, Fixed, 95\% CI) & Not estimable \\
\hline 5.2 final follow-up & 0 & 0 & Std. Mean Difference (IV, Fixed, 95\% CI) & Not estimable \\
\hline 6 Psychological Status & 2 & & Std. Mean Difference (IV, Fixed, 95\% CI) & Subtotals only \\
\hline 6.1 post-treatment results & 2 & 203 & Std. Mean Difference (IV, Fixed, 95\% CI) & $-0.25[-0.52,0.03]$ \\
\hline 6.2 final follow-up & 1 & 69 & Std. Mean Difference (IV, Fixed, 95\% CI) & $0.11[-0.36,0.58]$ \\
\hline 7 Anxiety & 1 & & Std. Mean Difference (IV, Fixed, 95\% CI) & Subtotals only \\
\hline 7.1 post-treatment results & 1 & 69 & Std. Mean Difference (IV, Fixed, 95\% CI) & $-0.08[-0.55,0.40]$ \\
\hline 7.2 final follow-up & 1 & 69 & Std. Mean Difference (IV, Fixed, 95\% CI) & $0.14[-0.33,0.62]$ \\
\hline 8 Depression & 3 & & Std. Mean Difference (IV, Fixed, 95\% CI) & Subtotals only \\
\hline 8.1 post-treatment results & 3 & 139 & Std. Mean Difference (IV, Fixed, 95\% CI) & $-0.17[-0.50,0.17]$ \\
\hline 8.2 final follow-up & 1 & 69 & Std. Mean Difference (IV, Fixed, 95\% CI) & $0.01[-0.46,0.49]$ \\
\hline 9 Disease Activity & 1 & & Std. Mean Difference (IV, Fixed, 95\% CI) & Subtotals only \\
\hline
\end{tabular}

Patient education for adults with rheumatoid arthritis (Review) 


\begin{tabular}{|c|c|c|c|c|}
\hline Outcome or subgroup title & $\begin{array}{l}\text { No. of } \\
\text { studies }\end{array}$ & $\begin{array}{c}\text { No. of } \\
\text { participants }\end{array}$ & Statistical method & Effect size \\
\hline 1 Pain & 27 & & Std. Mean Difference (IV, Fixed, 95\% CI) & Subtotals only \\
\hline 1.1 post-treatment results & 26 & 1453 & Std. Mean Difference (IV, Fixed, 95\% CI) & $-0.09[-0.19,0.02]$ \\
\hline 1.2 final follow-up & 15 & 841 & Std. Mean Difference (IV, Fixed, 95\% CI) & $-0.11[-0.24,0.03]$ \\
\hline 2 Disability & 28 & & Std. Mean Difference (IV, Fixed, 95\% CI) & Subtotals only \\
\hline 2.1 post-treatment results & 27 & 1532 & Std. Mean Difference (IV, Fixed, 95\% CI) & $-0.21[-0.32,-0.11]$ \\
\hline 2.2 final follow-up & 18 & 1003 & Std. Mean Difference (IV, Fixed, 95\% CI) & $-0.12[-0.24,0.01]$ \\
\hline 3 Joint Counts & 19 & & Std. Mean Difference (IV, Fixed, 95\% CI) & Subtotals only \\
\hline 3.1 post-treatment results & 16 & 751 & Std. Mean Difference (IV, Fixed, 95\% CI) & $-0.11[-0.25,0.04]$ \\
\hline 3.2 final follow-up & 12 & 737 & Std. Mean Difference (IV, Fixed, 95\% CI) & $-0.10[-0.25,0.04]$ \\
\hline 4 Patient Global Assessment & 6 & & Std. Mean Difference (IV, Fixed, 95\% CI) & Subtotals only \\
\hline 4.1 post-treatment results & 4 & 236 & Std. Mean Difference (IV, Fixed, 95\% CI) & $-0.30[-0.55,-0.04]$ \\
\hline 4.2 final follow-up & 5 & 424 & Std. Mean Difference (IV, Fixed, 95\% CI) & $-0.07[-0.26,0.12]$ \\
\hline 5 Physician Global Assessment & 0 & & Std. Mean Difference (IV, Fixed, 95\% CI) & Subtotals only \\
\hline 5.1 post-treatment results & 0 & 0 & Std. Mean Difference (IV, Fixed, 95\% CI) & Not estimable \\
\hline 5.2 final follow-up & 0 & 0 & Std. Mean Difference (IV, Fixed, 95\% CI) & Not estimable \\
\hline 6 Psychological Status & 13 & & Std. Mean Difference (IV, Fixed, 95\% CI) & Subtotals only \\
\hline 6.1 post-treatment results & 13 & 678 & Std. Mean Difference (IV, Fixed, 95\% CI) & $-0.04[-0.19,0.11]$ \\
\hline 6.2 final follow-up & 9 & 551 & Std. Mean Difference (IV, Fixed, 95\% CI) & $0.07[-0.10,0.24]$ \\
\hline 7 Anxiety & 15 & & Std. Mean Difference (IV, Fixed, 95\% CI) & Subtotals only \\
\hline 7.1 post-treatment results & 14 & 1032 & Std. Mean Difference (IV, Fixed, 95\% CI) & $-0.06[-0.18,0.07]$ \\
\hline 7.2 final follow-up & 13 & 788 & Std. Mean Difference (IV, Fixed, 95\% CI) & Not estimable \\
\hline 8 Depression & 22 & & Std. Mean Difference (IV, Fixed, 95\% CI) & Subtotals only \\
\hline 8.1 post-treatment results & 21 & 1350 & Std. Mean Difference (IV, Fixed, 95\% CI) & $-0.14[-0.25,-0.04]$ \\
\hline 8.2 final follow-up & 16 & 911 & Std. Mean Difference (IV, Fixed, 95\% CI) & $-0.12[-0.25,0.01]$ \\
\hline 9 Disease Activity & 14 & & Std. Mean Difference (IV, Fixed, 95\% CI) & Subtotals only \\
\hline 9.1 post-treatment results & 11 & 422 & Std. Mean Difference (IV, Fixed, 95\% CI) & $-0.11[-0.30,0.09]$ \\
\hline 9.2 final follow-up & 9 & 594 & Std. Mean Difference (IV, Fixed, 95\% CI) & $-0.11[-0.27,0.06]$ \\
\hline
\end{tabular}


Analysis I.I. Comparison I Patient Education versus Controls, Outcome I Pain.

Review: Patient education for adults with rheumatoid arthritis

Comparison: I Patient Education versus Controls

Outcome: I Pain

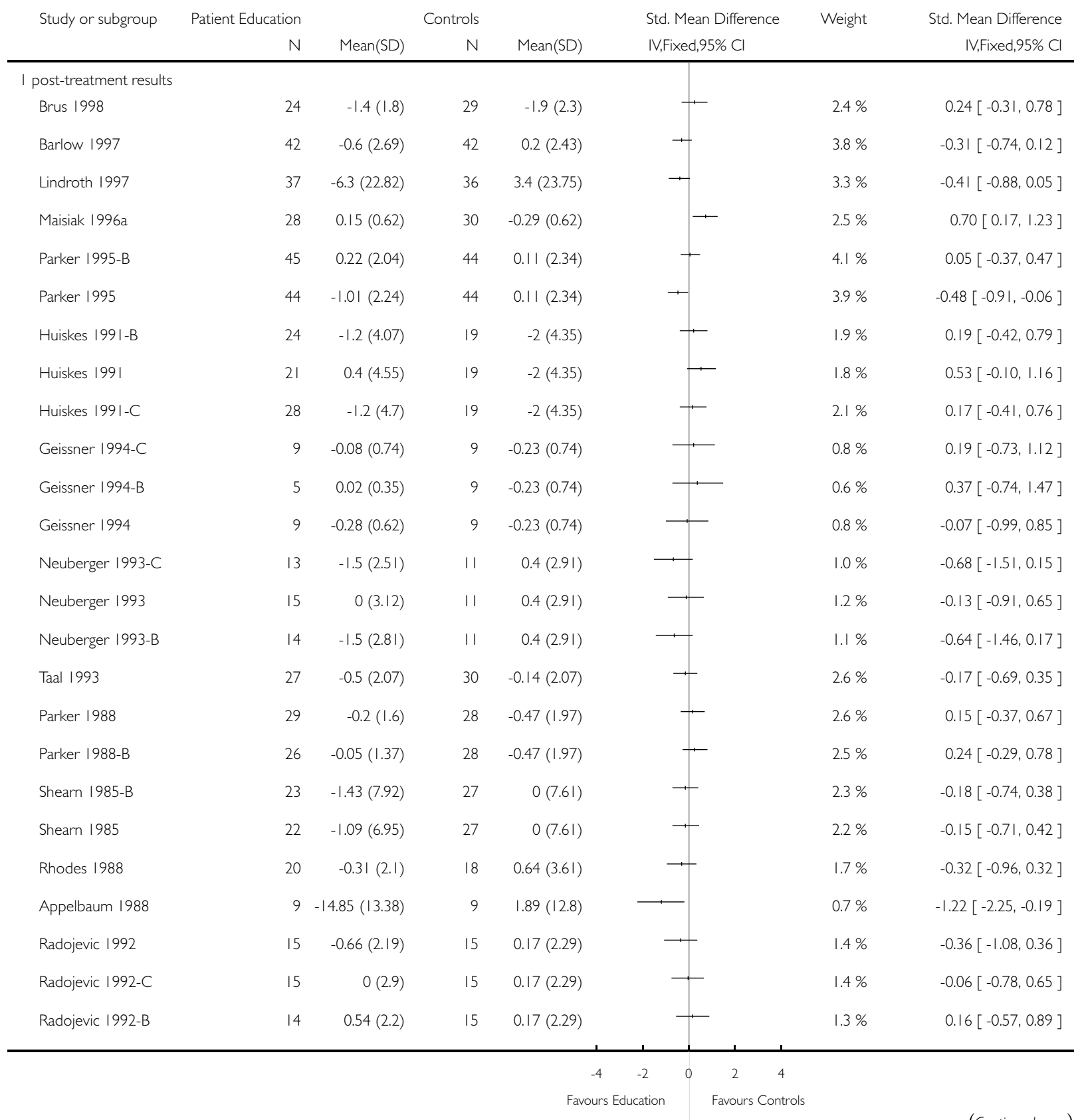

(Continued ... ) 


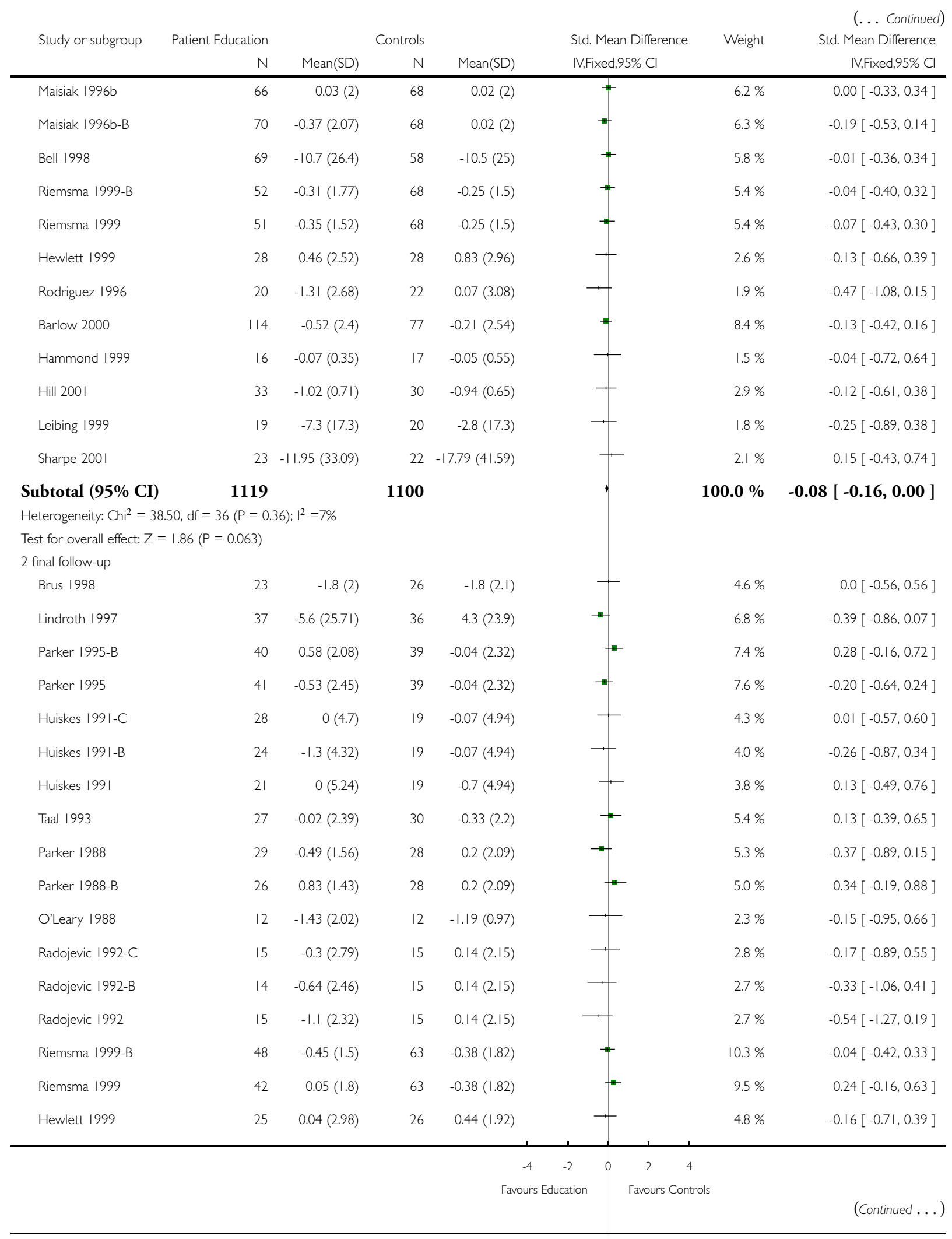

Patient education for adults with rheumatoid arthritis (Review)

Copyright (־ 2009 The Cochrane Collaboration. Published by John Wiley \& Sons, Ltd. 


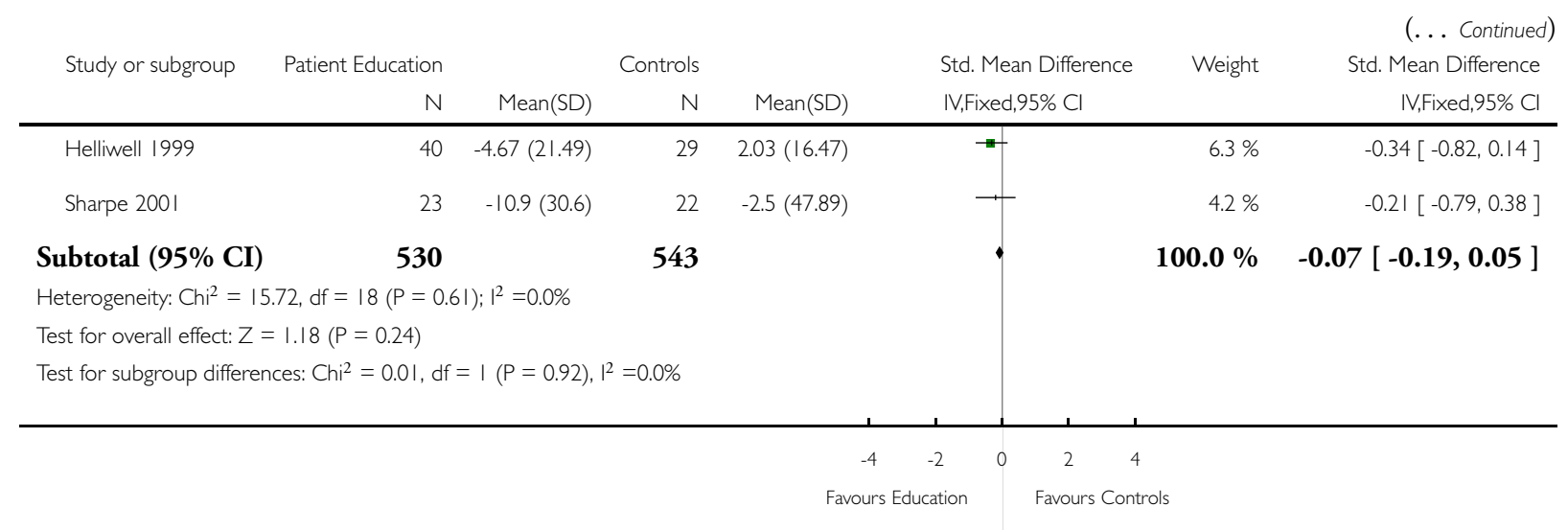

\section{Analysis I.2. Comparison I Patient Education versus Controls, Outcome 2 Disability.}

Review: Patient education for adults with rheumatoid arthritis

Comparison: I Patient Education versus Controls

Outcome: 2 Disability

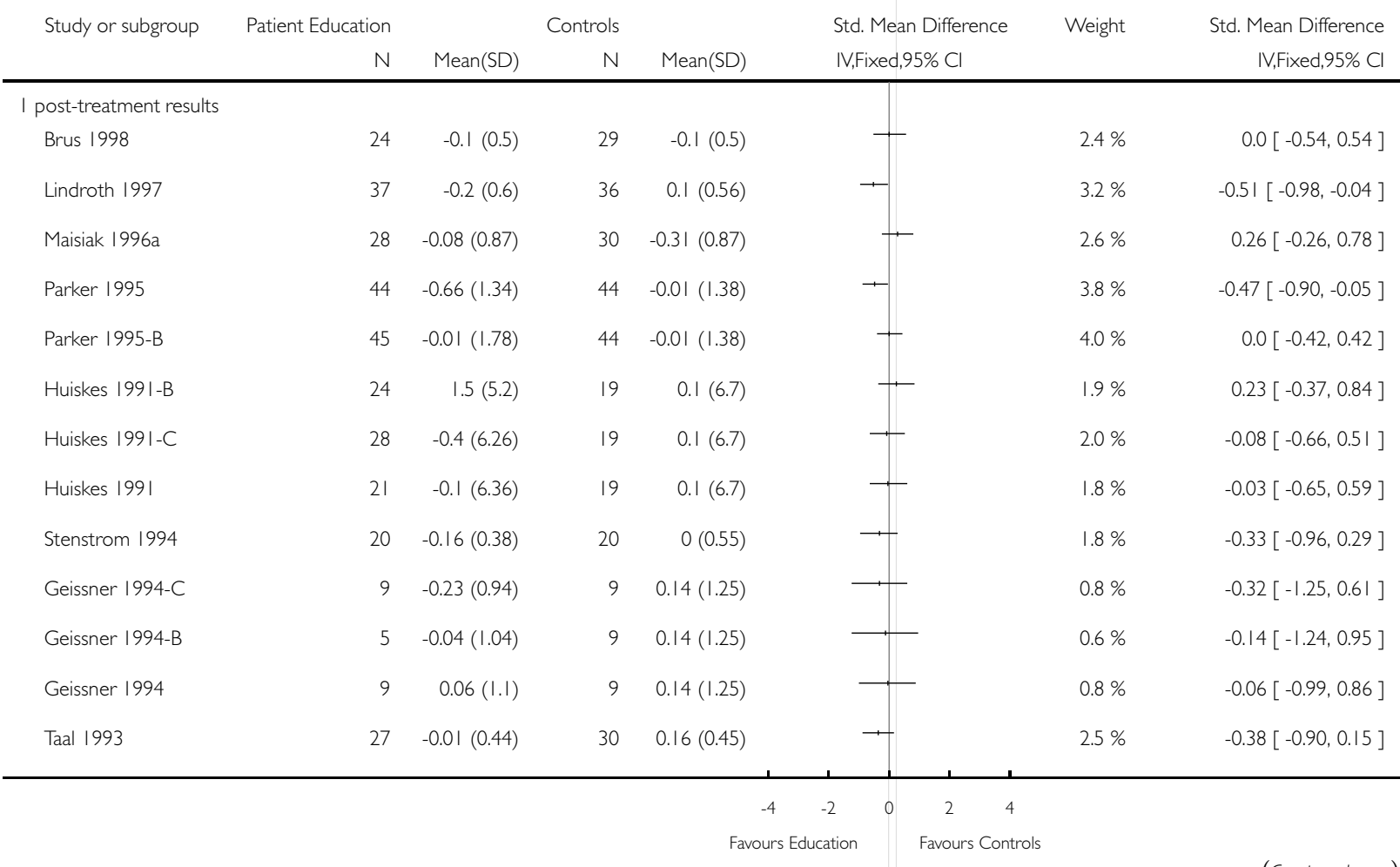

(Continued ...) 


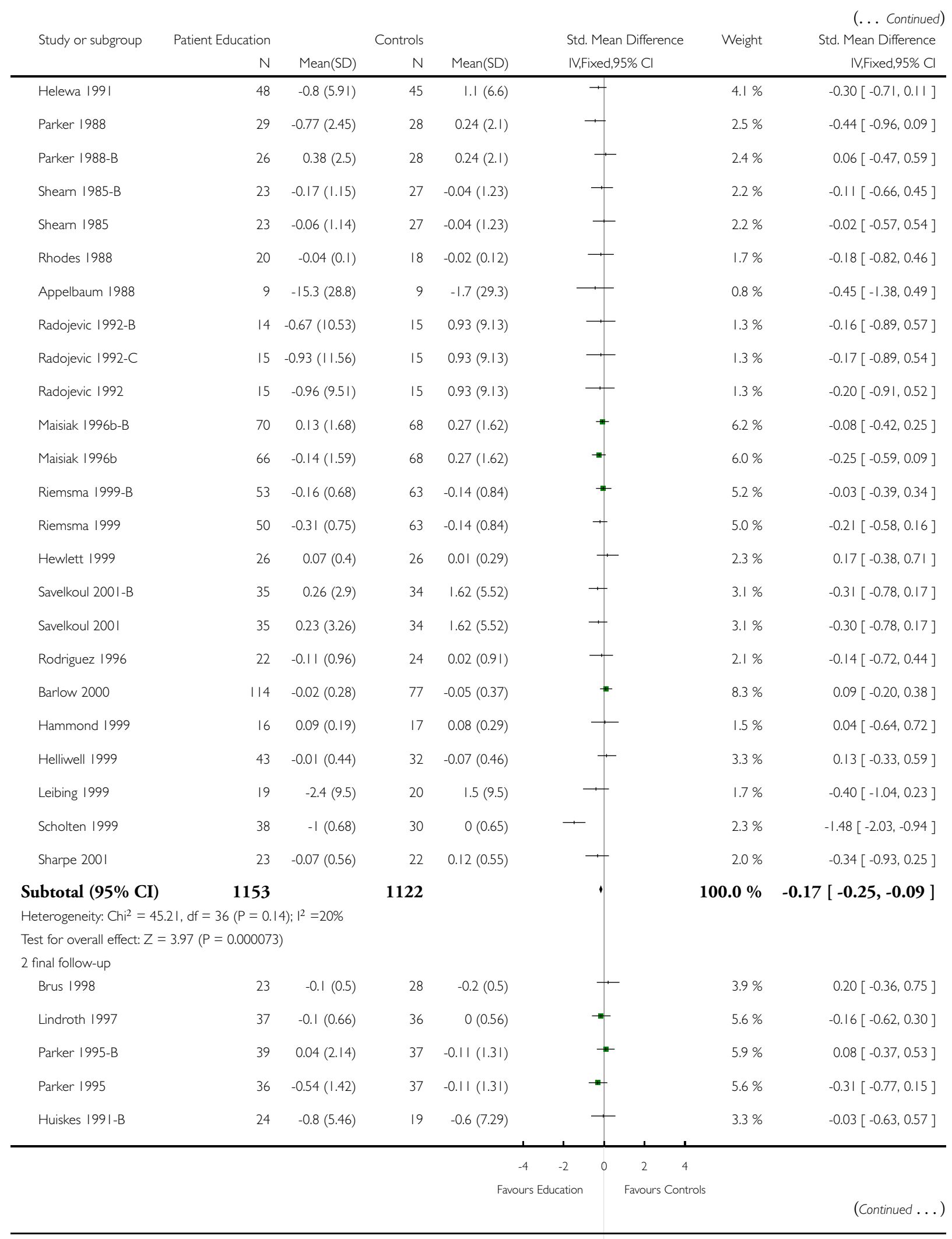

Patient education for adults with rheumatoid arthritis (Review)

Copyright (? 2009 The Cochrane Collaboration. Published by John Wiley \& Sons, Ltd. 


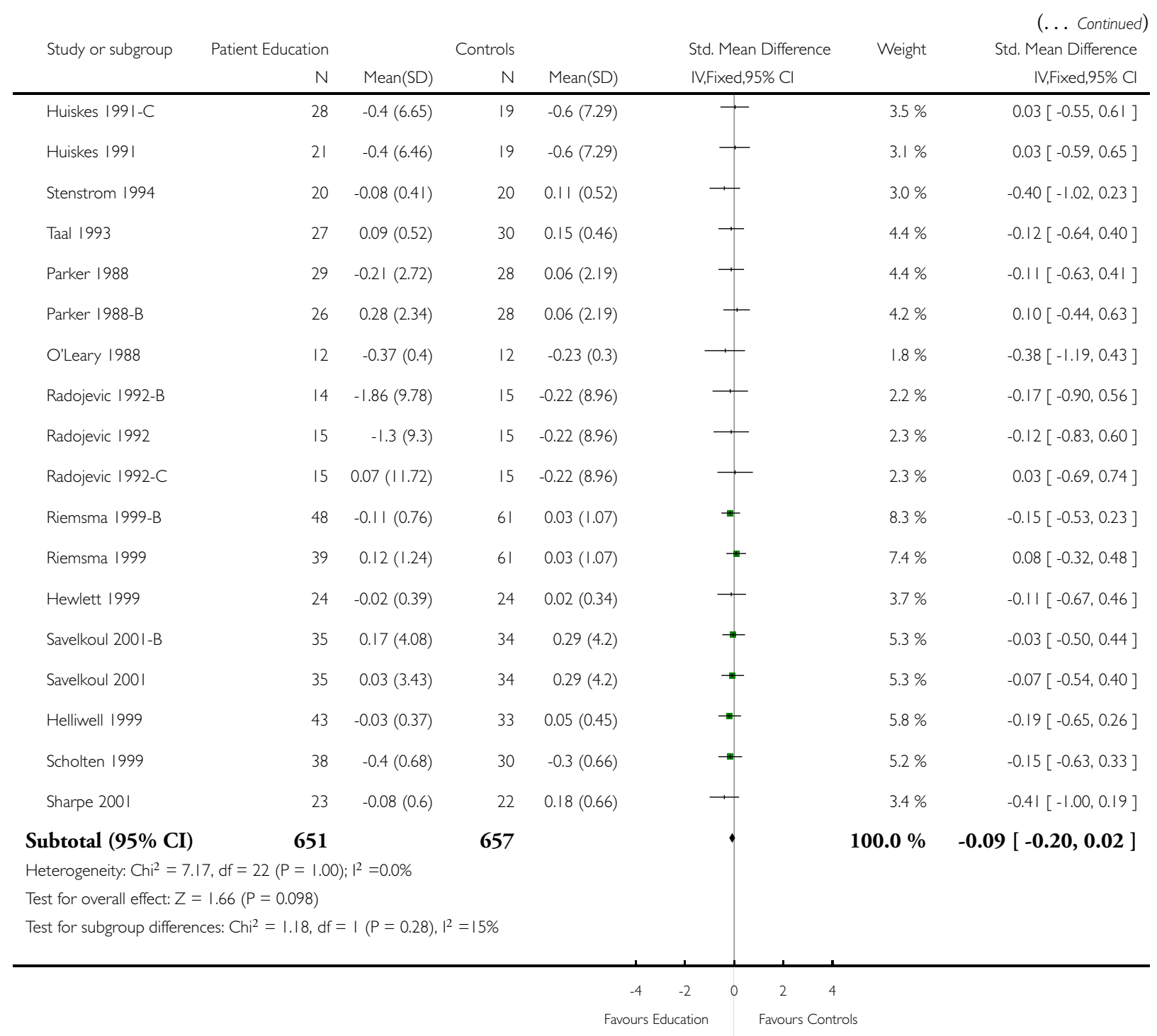




\section{Analysis I.3. Comparison I Patient Education versus Controls, Outcome 3 Joint Counts.}

Review: Patient education for adults with rheumatoid arthritis

Comparison: I Patient Education versus Controls

Outcome: 3 Joint Counts

Study or subgroup Patient Education $\quad$ Controls Std. Mean Difference Weight $\quad$ Std. Mean Difference

$\begin{array}{llll}N & \text { Mean(SD) N } \quad \text { Mean(SD) IV,Random,95\% Cl IV,Random,95\% Cl }\end{array}$

I post-treatment results

Brus 1998

$-1.4(13.21)$

Parker 1995

Parker 1995-B

Huiskes 199|-C

Huiskes |99|-B

$25-1.4(13.21)$

$30-0.97(6.01)$ (1) $95 \% \mathrm{Cl}$

Stenstrom 1994

Geissner 1994-C

$44 \quad-2.34(9.4)$

$44-1.79(10.6)$

$45-1.25(10.29)$

$44 \quad-1.79(10.6)$

$28 \quad-7.65$ (97.94)

$19 \quad-26.7(90.96)$

$24 \quad 22.98(89.21)$

$19 \quad-26.7(90.96)$

$20-10.3(12.52)$

$20-2.8(|5.7|)$

Geissner 1994

Geissner 1994-B

$9 \quad-2.75(5.28)$

$9 \quad-0.92(5.35)$

$9 \quad-0.6(11.23)$

$9 \quad-0.92(5.35)$

Parker 1988-B

Parker 1988

$$
0 \text { (6.57) }
$$

$9 \quad-0.92(5.35)$

$26 \quad 2.5(14.32)$

$28 \quad 6.25$ (13.58)

Shearn 1985

$29 \quad 6.34(12.85)$

$28 \quad 6.25(13.58)$

Shearn 1985-B

$19-2.61(8.49)$

28

$0.32(8.5)$

$23-2.74(10.92)$

$0.32(8.5)$

Radojevic 1992-B

Radojevic 1992-C

$14 \quad-5.36(13.2)$

$15 \quad 3.73(14.82)$

$15-1.67(14.77)$

I5 $3.73($ I 4.82$)$

Radojevic 1992

$15-8.93(13.24)$

I5 $3.73($ (14.82)

Bell 1998

$69-4.7(12.8)$

$58 \quad-3.8(12.5)$

Hewlett 1999

Rodriguez 1996

$27 \quad-2.7(89.95)$

$27 \quad 16.22(102.55)$

Helliwell 1999

Hill 2001

$22-1.82(5.8)$

$23 \quad 0.78(6.6)$

$42 \quad-2.24(6.24)$

$33-1.85(5.66)$

Leibing 1999

Sharpe 2001

$33-13(10.99)$

$30-11.8(12.27)$

$19 \quad 0.7(12.5)$

$20 \quad-3.7(12.5)$

23

$-3(9.63)$

22

$1.17(9.75)$

585

573

Subtotal (95\% CI)

Heterogeneity: $\mathrm{Tau}^{2}=0.0 ; \mathrm{Chi}^{2}=20.23, \mathrm{df}=22(\mathrm{P}=0.57) ; \mathrm{I}^{2}=0.0 \%$

\begin{tabular}{|c|c|}
\hline $4.8 \%$ & $-0.04[-0.57,0.49]$ \\
\hline $7.5 \%$ & $-0.05[-0.47,0.36]$ \\
\hline $7.6 \%$ & $0.05[-0.36,0.47]$ \\
\hline $4.0 \%$ & $0.20[-0.39,0.78]$ \\
\hline $3.7 \%$ & $0.54[-0.07,1.16]$ \\
\hline $3.5 \%$ & $-0.52[-1.15,0.11]$ \\
\hline $1.6 \%$ & $-0.33[-1.26,0.60]$ \\
\hline $1.7 \%$ & $0.03[-0.89,0.96]$ \\
\hline $1.2 \%$ & $0.15[-0.95,1.24]$ \\
\hline $4.7 \%$ & $-0.27[-0.80,0.27]$ \\
\hline $5.0 \%$ & $0.01[-0.5 \mathrm{I}, 0.53]$ \\
\hline $4.0 \%$ & $-0.34[-0.93,0.25]$ \\
\hline $4.4 \%$ & $-0.31[-0.87,0.24]$ \\
\hline $2.5 \%$ & $-0.63[-1.38,0.12]$ \\
\hline $2.7 \%$ & $-0.36[-1.08,0.37]$ \\
\hline $2.5 \%$ & $-0.88[-1.63,-0.12]$ \\
\hline $10.4 \%$ & $-0.07[-0.42,0.28]$ \\
\hline $4.8 \%$ & $-0.19[-0.73,0.34]$ \\
\hline $3.9 \%$ & $-0.41[-1.00,0.18]$ \\
\hline $6.4 \%$ & $-0.06[-0.52,0.39]$ \\
\hline $5.5 \%$ & $-0.10[-0.60,0.39]$ \\
\hline $3.5 \%$ & $0.34[-0.29,0.98]$ \\
\hline $3.9 \%$ & $-0.42[-1.01,0.17]$ \\
\hline
\end{tabular}

$100.0 \%-0.13[-0.24,-0.01]$

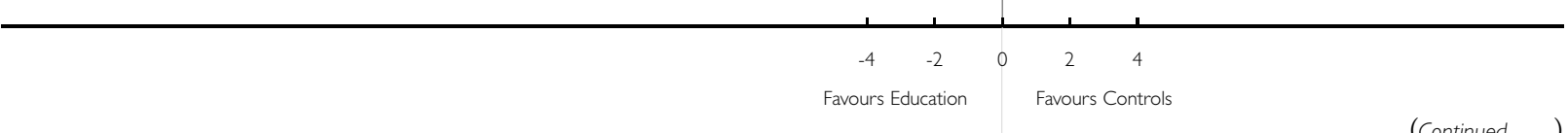




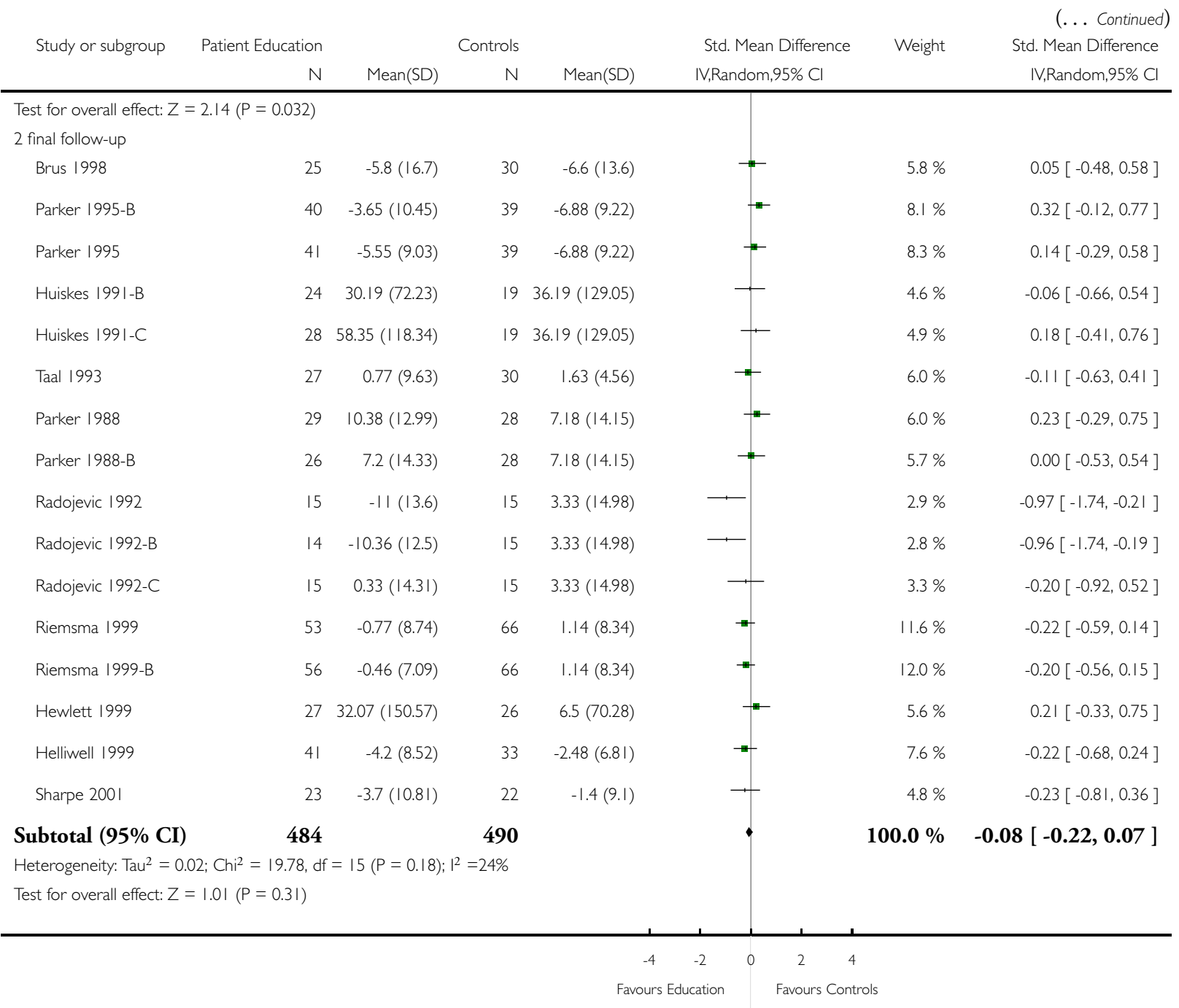


Analysis I.4. Comparison I Patient Education versus Controls, Outcome 4 Patient Global Assessment. Review: Patient education for adults with rheumatoid arthritis

Comparison: I Patient Education versus Controls

Outcome: 4 Patient Global Assessment

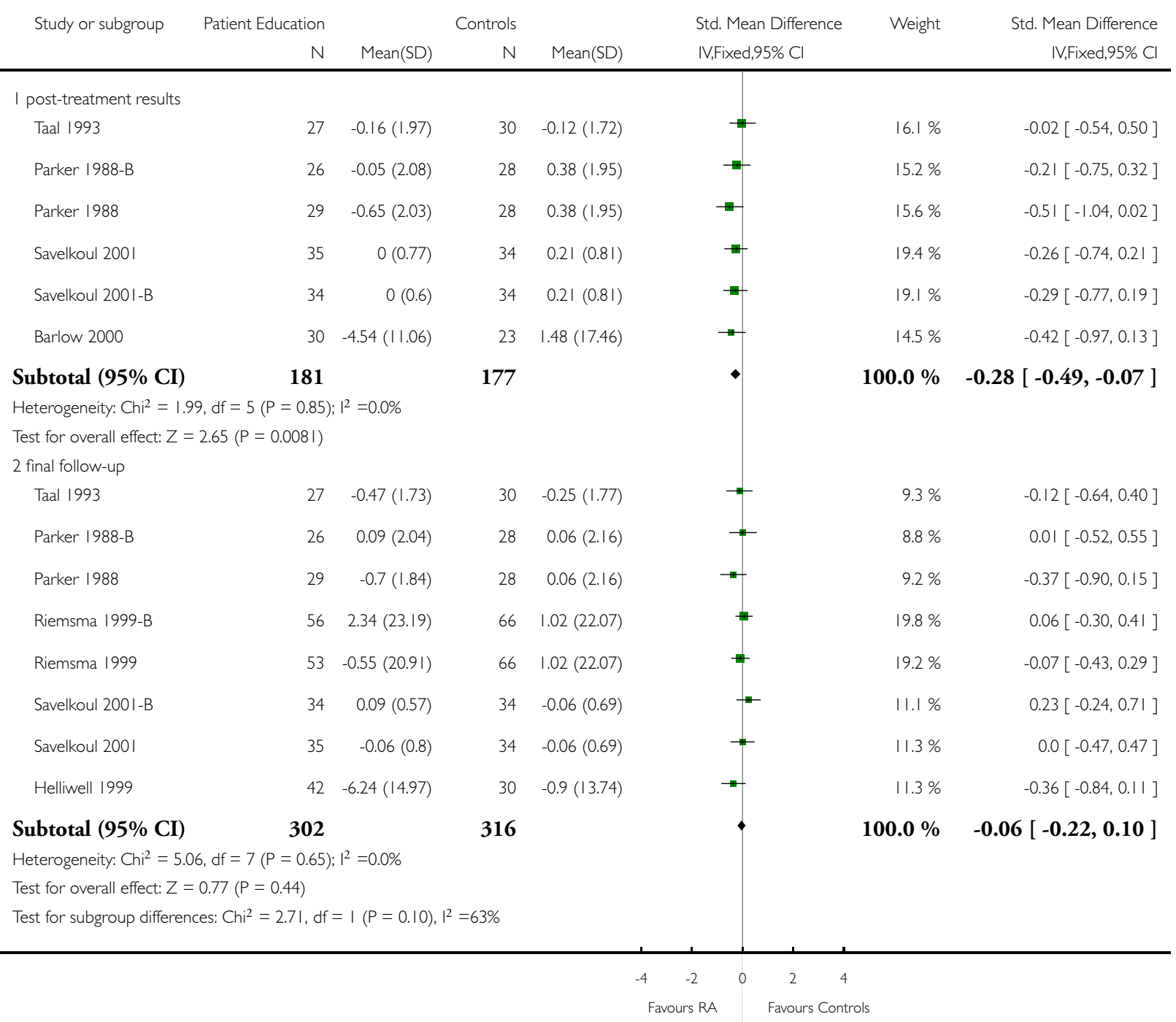


Analysis I.6. Comparison I Patient Education versus Controls, Outcome 6 Psychological Status.

Review: Patient education for adults with rheumatoid arthritis

Comparison: I Patient Education versus Controls

Outcome: 6 Psychological Status

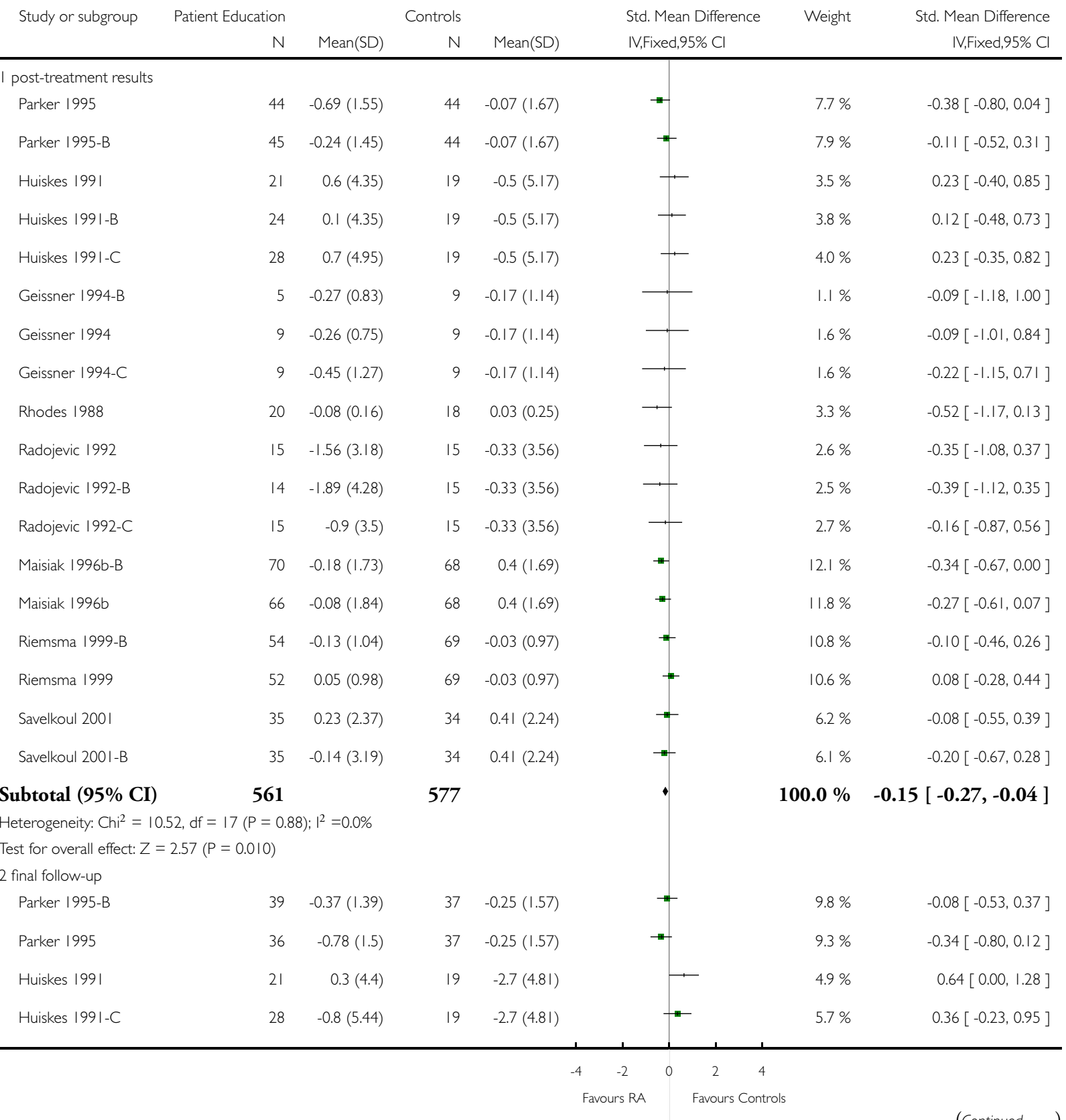

(Continued....) 


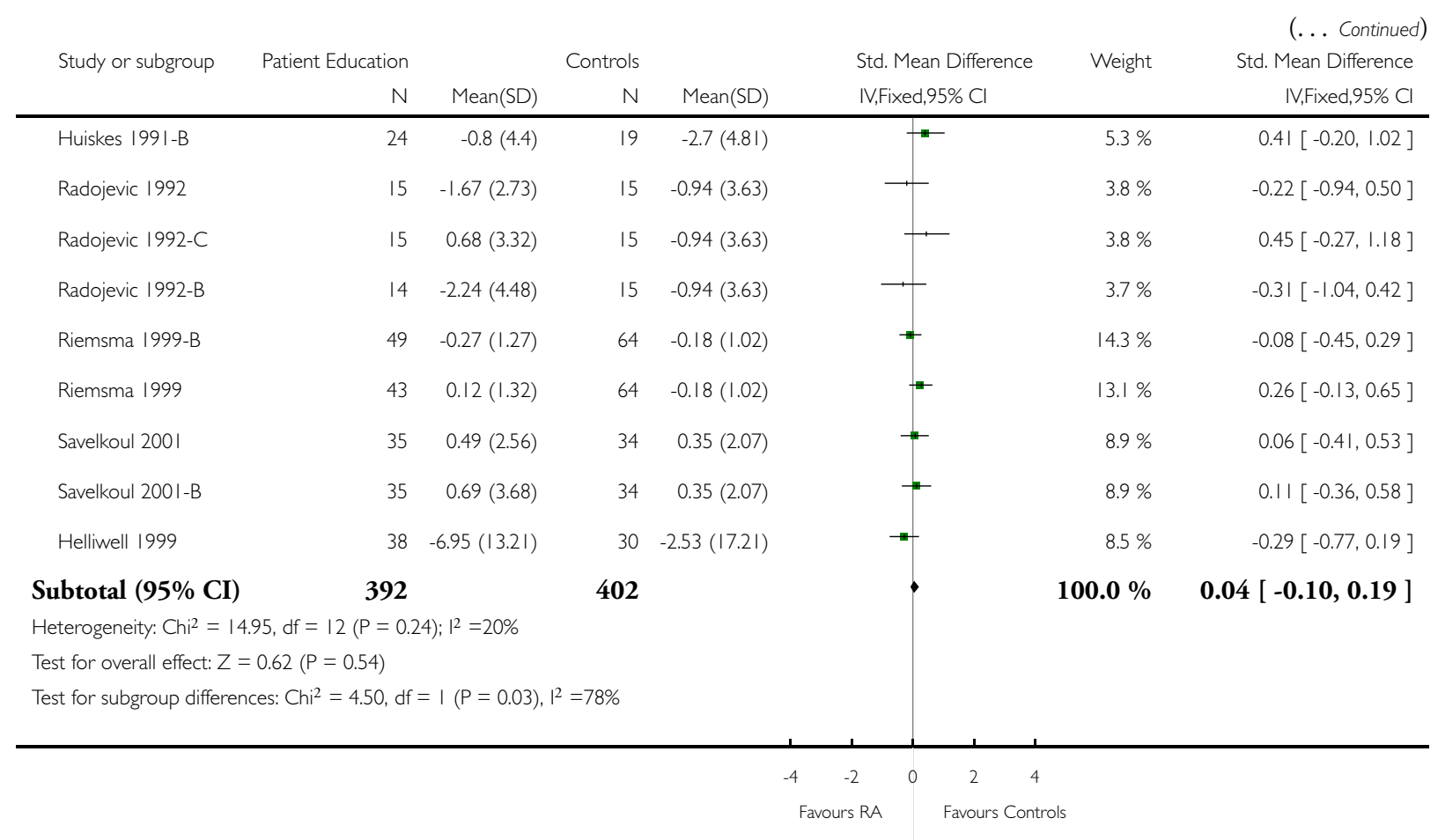




\section{Analysis I.7. Comparison I Patient Education versus Controls, Outcome 7 Anxiety.}

Review: Patient education for adults with rheumatoid arthritis

Comparison: I Patient Education versus Controls

Outcome: 7 Anxiety

Study or subgroup Patient Education

Mean(SD)

Controls

Std. Mean Difference Weight

Std. Mean Difference

$\mathrm{N} \quad \operatorname{Mean}(\mathrm{SD})$

N Mean(SD) IV,Fixed, $95 \% \mathrm{Cl}$

V,Fixed,95\% Cl

I post-treatment results

Brus 1998

23

$-0.3(1.6)$

$-0.7(1.6)$

Barlow 1997

Parker 1995-B

$42 \quad 0.38(2.38)$

$42 \quad 0.16(2.81)$

Parker 1995

Huiskes 1991-C

$-1.23(9.08)$

$44-1.21(9.24)$

$44 \quad-2.21(8.34)$

$44 \quad-1.21(9.24)$

Huiskes 199|-B

Huiskes 1991

Taal 1993

Parker 1988

$-0.2(5.76)$

$9 \quad-0.9(5.57)$

$24 \quad 0.9(5.5 \mathrm{I})$

$19-0.9(5.57)$

$21 \quad-0.3(5.86)$

$9 \quad-0.9(5.57)$

$27-0.68(1.95)$

$-0.26(1.9)$

Parker 1988-B

Riemsma 1999-B

$-0.33(1.69)$

$-0.15(1.88)$

Riemsma 1999

Hewlett 1999

0.01 (1.87)

$0.15(1.88)$

$0.01(1.51)$

$-0.05(1.41)$

Savelkoul 200I-B

$0.02(1.46)$

$70-0.05(1.4 I)$

$270.56(3.39)$

0.5 (3.94)

Savelkoul 2001

$35 \quad 0.06(2.34)$

$40.21(1.51)$

Barlow 2000

$35 \quad 0.14(1.91)$

$34 \quad 0.21(1.5 \mathrm{I})$

Leibing 1999

$114 \quad-1.11(2.97)$

77

$-0.52(2.9)$

$19-2.5(6)$

20

I (6)

Sharpe 2001

$23-1.52(5.17)$

$220.46(5.29)$

Subtotal (95\% CI)

671

657

Heterogeneity: $\mathrm{Chi}^{2}=9.57, \mathrm{df}=17(\mathrm{P}=0.92) ; \mathrm{I}^{2}=0.0 \%$

Test for overall effect: $Z=0.7 \mathrm{I}(P=0.48)$

2 final follow-up

$\begin{array}{lcccc}\text { Brus 1998 } & 23 & -0.3(1.9) & 28 & -0.6(1.7) \\ \text { Parker 1995 } & 41 & -2.57(8.15) & 39 & -1.61(9.41) \\ \text { Parker 1995-B } & 40 & -1.66(8.06) & 39 & -1.61(9.41) \\ \text { Huiskes 199I-C } & 28 & 0.5(6.03) & 19 & 0.5(6.5)\end{array}$

$+$

$3.9 \% \quad 0.25[-0.30,0.80]$

$6.4 \%$

$0.08[-0.34,0.51]$

$6.8 \%$

$0.00[-0.42,0.41]$

$6.7 \%$

$-0.11[-0.53,0.31]$

$3.5 \%$

$0.12[-0.46,0.70]$

$3.2 \%$

$0.32[-0.29,0.93]$

$3.0 \%$

$0.10[-0.52,0.72]$

$4.3 \%$

$-0.22[-0.74,0.31]$

$4.4 \%$

$-0.10[-0.62,0.42]$

$4.1 \%$

$0.08[-0.45,0.62]$

$9.4 \%$

$0.04[-0.31,0.39]$

$9.3 \%$

$0.05[-0.31,0.40]$

$4.2 \%$

$0.02[-0.51,0.54]$

$5.3 \%$

$-0.08[-0.55,0.40]$

$5.3 \%$

$-0.04[-0.51,0.43]$

$14.0 \%$

$-0.20[-0.49,0.09]$

$2.9 \%$

$-0.57[-1.21,0.07]$

$3.4 \%$

$-0.37[-0.96,0.22]$

$100.0 \%$

$-0.04[-0.15,0.07$ ]

$28 \quad 0.5(6.03)$

$0.5(6.5)$ 


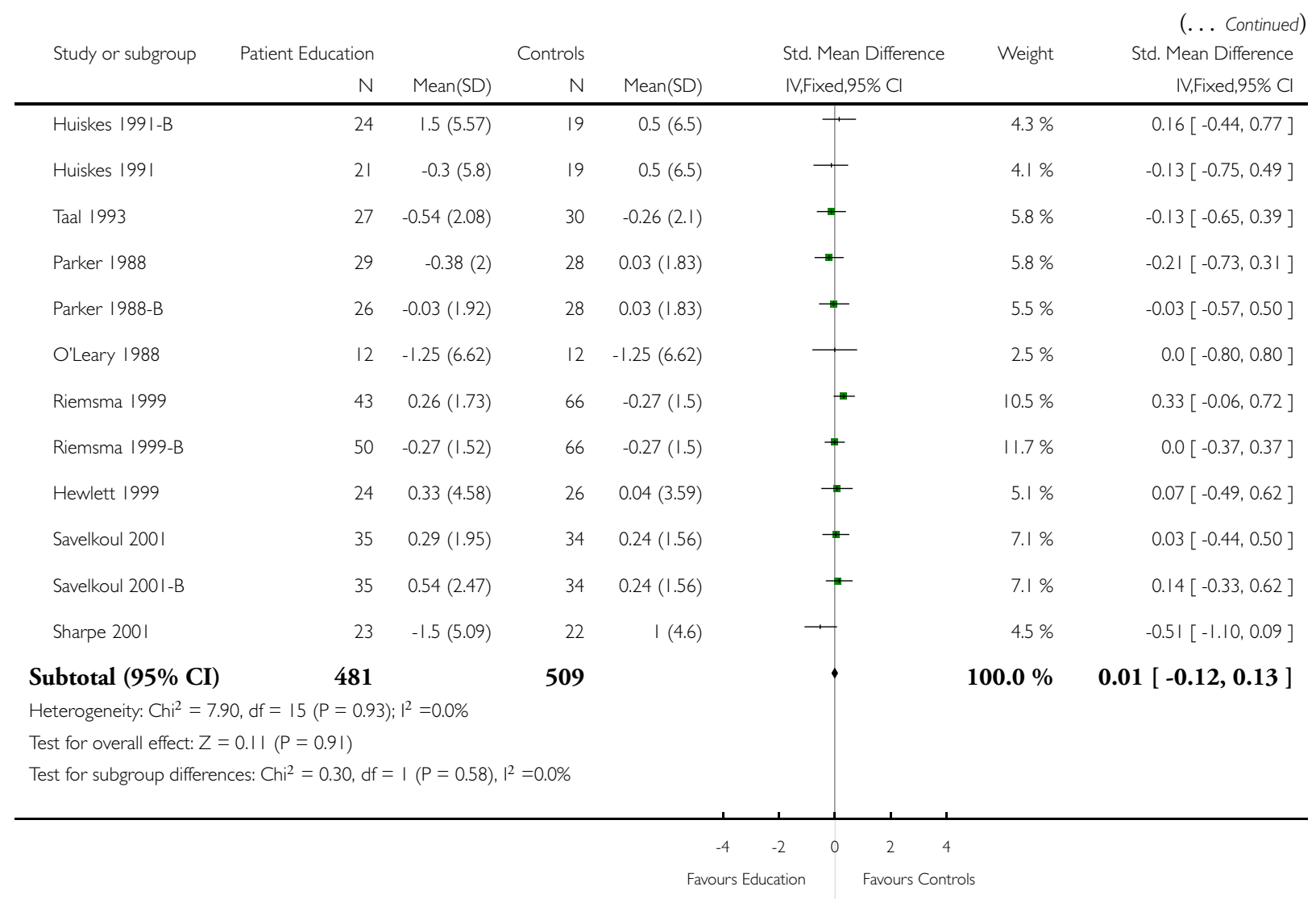


Analysis I.8. Comparison I Patient Education versus Controls, Outcome 8 Depression.

Review: Patient education for adults with rheumatoid arthritis

Comparison: I Patient Education versus Controls

Outcome: 8 Depression

Study or subgroup Patient Education

Controls

Mean(SD)

Std. Mean Difference Weight

Std. Mean Difference

N $\quad \operatorname{Mean}(\mathrm{SD})$

$\mathrm{N} \quad \operatorname{Mean}(\mathrm{SD})$

IV,Fixed,95\% Cl

IV,Fixed,95\% Cl

I post-treatment results

Brus 1998

$24 \quad-0.4(1.4) \quad 29 \quad-0.5(1.6)$

Barlow 1997

Parker 1995-B

$\begin{array}{llll}42 & -0.33(1.99) & 42 & 0.5(3.28)\end{array}$

Parker 1995

Huiskes 199|-C

$45 \quad 0.67(8.67)$

$44 \quad 0.62(8.65)$

$44-3.21(8.24)$

$0.62(8.65)$

Huiskes 199|

Huiskes |99|-B

Neuberger $1993-C$

Neuberger 1993-B

Neuberger 1993

Taal 1993

Helewa 1991

Parker 1988

Parker 1988-B

Shearn 1985

Shearn 1985-B

Kaplan 1981

Radojevic 1992-B

Radojevic 1992

Radojevic 1992-C

Riemsma 1999-B

Riemsma 1999

Hewlett 1999

Savelkoul 200I-B

Savelkoul 200।

$49-2(6.56)$

$45-1.2(7.07)$

$29-0.45(1.4)$

$-0.1(1.39)$

$26-0.12(1.53)$

28

-0.1 (1.39)

$22 \quad 1.3(17.12)$

$-0.7(17.21)$

$22-2.3(19.51)$

$6-0.7(17.21)$

I I (14.09)

II I.I (14.31)

$14 \quad 0.22(12.09)$

$15 \quad-1.67(9.93)$

$15-0.67(10.89)$

$15 \quad-1.67(9.93)$

$15 \quad-4.2(9.19)$

$15 \quad-1.67(9.93)$

$54-0.19(0.94)$

$69 \quad 0.01(0.93)$

$54-0.05(1.01)$

$69 \quad 0.01(0.93)$

$27-0.19(1.71)$

$28 \quad 0.04(4.08)$

$35-0.2(1.57)$

34

$35 \quad 0.09(1.15)$

34

$0.21(1.41)$

$0.21(1.41)$

$+\quad 3.0 \%$

$0.07[-0.48,0.61]$

$-0.30[-0.73,0.13]$

0.01 [ $-0.41,0.42$ ]

$-0.45[-0.87,-0.03]$

$-0.13[-0.72,0.45]$

$-0.02[-0.64,0.60]$

$0.59[-0.03,1.21]$

$0.20[-0.61,1.00]$

$-0.10[-0.89,0.69]$

$0.11[-0.66,0.89]$

$-0.06[-0.58,0.46]$

$-0.12[-0.52,0.29]$

$-0.25[-0.77,0.27]$

$-0.01[-0.55,0.52]$

$0.11[-0.45,0.68]$

$-0.09[-0.65,0.48]$

$-0.01[-0.84,0.83]$

$0.17[-0.56,0.90]$

$0.09[-0.62,0.81]$

$-0.26[-0.98,0.46]$

$-0.21[-0.57,0.14]$

$-0.06[-0.42,0.29]$

$-0.07[-0.60,0.46]$

$-0.27[-0.75,0.20]$

$-0.09[-0.56,0.38]$

$4.0 \%$

Favours Education

(Continued....) 


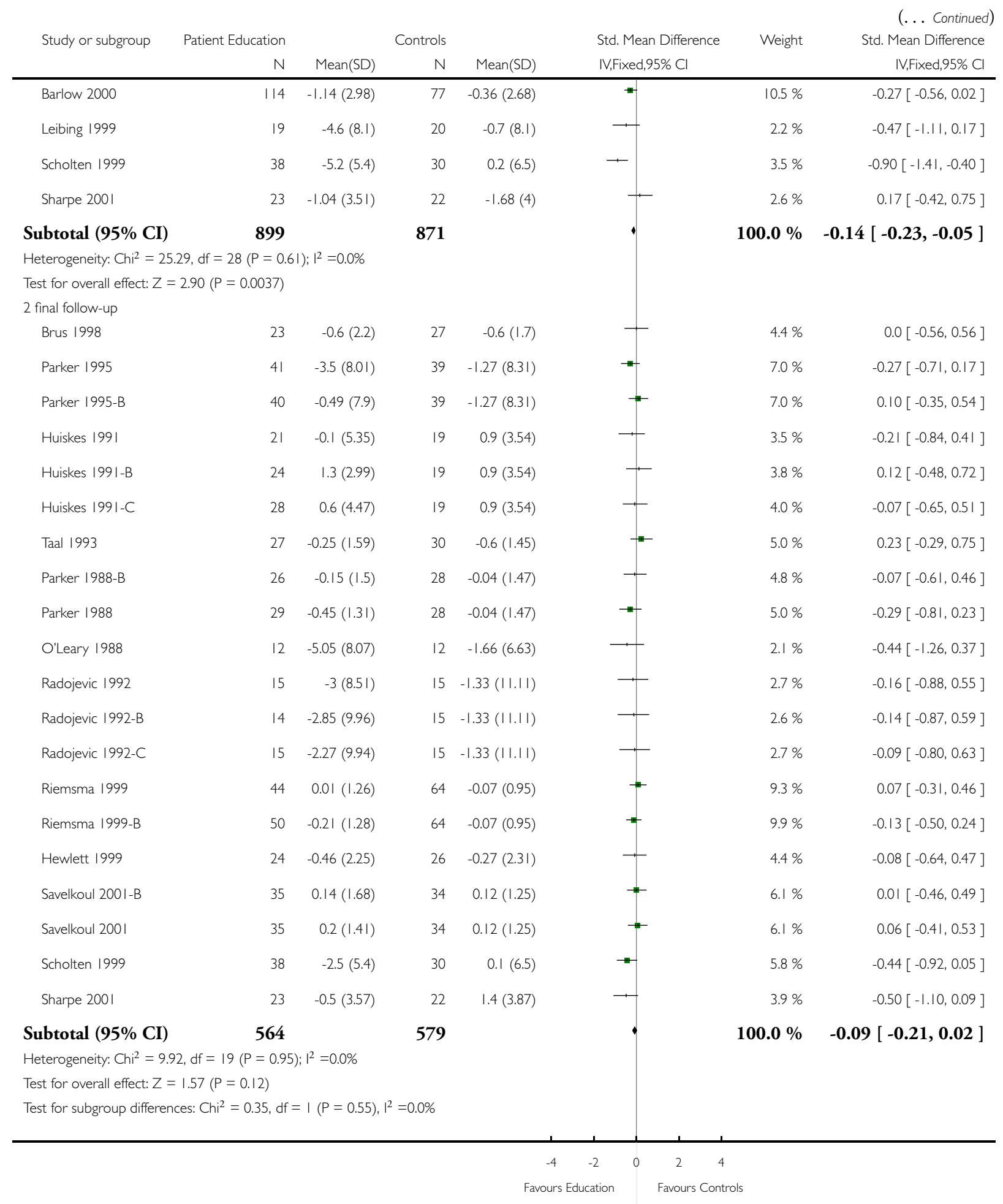

Patient education for adults with rheumatoid arthritis (Review) 


\section{Analysis I.9. Comparison I Patient Education versus Controls, Outcome 9 Disease Activity.}

Review: Patient education for adults with rheumatoid arthritis

Comparison: I Patient Education versus Controls

Outcome: 9 Disease Activity

Study or subgroup Patient Education

Controls

Std. Mean Difference Weight

Std. Mean Difference

N Mean(SD)

N

Mean(SD)

IV,Fixed,95\% Cl

IV,Fixed,95\% Cl

I post-treatment results

Brus 1998

$25-20.4(18.96)$

$-19.27(21.49)$

Huiskes 199|-B

$24 \quad 9.12(20.01)$

$97.5(22.84)$

Huiskes 1991-C

$28-3.42(26.45)$

$9.5(22.84)$

Geissner 1994

$9 \quad-0.08(24.85)$

9 $-1.75(22.93)$

Geissner 1994-B

$5-3.34(31.85)$

$-1.75(22.93)$

Geissner 1994-C

$9 \quad-4.71(24.81)$

9 $-1.75(22.93)$

Parker 1988

$29 \quad 0.27(|4.5|)$

$28-6.15(25.46)$

Parker 1988-B

$26 \quad 3.04(24.02)$

Shearn 1985

$13-3(45.44)$

$-6.15(25.46)$

Shearn 1985-B

$16-2.7(63.15)$

23

-0.1 (54.18)

Hewlett 1999

$27 \quad-7(30.91)$

$-0.1(54.18)$

Helliwell 1999

$40-0.02(0.12)$

4 (14.98)

Hill 2001

$33-37.7(41.08)$

$-0.04(0.09)$

$30 \quad-32.7(54.18)$

Leibing 1999

$19 \quad 6.7(6.9)$

20

$7.6(6.9)$

Sharpe 200

$23-7.03(12.24)$

$22-3.14(17.71)$

Subtotal (95\% CI)

326

321

Heterogeneity: $\mathrm{Chi}^{2}=9.39, \mathrm{df}=|4(\mathrm{P}=0.8 \mathrm{I}) ;|^{2}=0.0 \%$

Test for overall effect: $Z=0.42(P=0.68)$

2 final follow-up

Brus 1998

Huiskes 1991-C

$25-28.04(30)$

$-27.14(23.7)$

$10.17(30.43)$

Huiskes |99|-B

Taal 1993

$28 \quad 5.07(32.04)$

$10.17(30.43)$

$24 \quad 9.37(19.4)$

9.5 (43.39)

Parker 1988-B

Parker 1988

$27 \quad 3.58(17.72)$

-5.76 (25.99)

$26-0.19(22.58)$

$28-5.76(25.99)$

Riemsma 1999-B

$29 \quad 0.11(13.4)$

$63 \quad 2.05(15.15)$

$7.6 \%$

$6.4 \%$

$6.0 \%$

$8.0 \%$

$7.5 \%$

$7.9 \%$

$16.3 \%$
$-0.05[-0.59,0.48]$

$0.07[-0.53,0.68]$

$-0.43[-1.02,0.16]$

$0.07[-0.86,0.99]$

$-0.05[-1.29,1.19]$

$-0.12[-1.04,0.81]$

$0.31[-0.22,0.83]$

$0.37[-0.17,0.90]$

$-0.06[-0.74,0.62]$

$-0.04[-0.68,0.59]$

$-0.45[-0.99,0.09]$

$0.18[-0.30,0.66]$

$-0.10[-0.60,0.39]$

$-0.13[-0.76,0.50]$

$-0.25[-0.84,0.33]$

$0.03[-0.19,0.12]$

$-0.03[-0.57,0.50]$

$-0.16[-0.74,0.42]$

$-0.03[-0.63,0.57]$

$-0.17[-0.69,0.35]$

$0.22[-0.31,0.76]$

$0.28[-0.24,0.80]$

$-0.25[-0.62,0.11]$ 


\begin{tabular}{|c|c|c|c|c|c|c|c|}
\hline \multirow[t]{2}{*}{ Study or subgroup } & \multirow{2}{*}{$\begin{array}{r}\text { Patient Education } \\
\mathrm{N}\end{array}$} & \multicolumn{3}{|c|}{ Controls } & \multirow{2}{*}{$\begin{array}{l}\text { Std. Mean Difference } \\
\text { IV,Fixed,95\% Cl }\end{array}$} & \multirow[t]{2}{*}{ Weight } & \multirow{2}{*}{$\begin{array}{r}\text { (... Continued) } \\
\text { Std. Mean Difference } \\
\text { IV,Fixed,95\% Cl }\end{array}$} \\
\hline & & Mean(SD) & $N$ & Mean(SD) & & & \\
\hline Riemsma 1999 & 56 & $-0.64(18.95)$ & 63 & $2.05(15.15)$ & 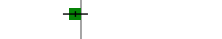 & $16.7 \%$ & $-0.16[-0.52,0.20]$ \\
\hline Hewlett 1999 & 28 & $-3.96(28.33)$ & 27 & $3.95(38.01)$ & $\rightarrow$ & $7.7 \%$ & $-0.23[-0.76,0.30]$ \\
\hline Helliwell 1999 & 39 & $-0.02(0.13)$ & 31 & $-0.05(0.14)$ & $\mp$ & $9.7 \%$ & $0.22[-0.25,0.69]$ \\
\hline Sharpe 200I & 23 & $1.8(18.84)$ & 22 & $0.3(22.86)$ & $\rightarrow$ & $6.3 \%$ & $0.07[-0.51,0.66]$ \\
\hline Subtotal $(95 \% \mathrm{CI})$ & 359 & & 359 & & - & $100.0 \%$ & $-0.05[-0.20,0.10]$ \\
\hline \multicolumn{8}{|c|}{ Heterogeneity: $\mathrm{Chi}^{2}=6.34, \mathrm{df}=10(\mathrm{P}=0.79) ; \mathrm{I}^{2}=0.0 \%$} \\
\hline \multicolumn{8}{|c|}{ Test for overall effect: $Z=0.65(P=0.52)$} \\
\hline \multicolumn{8}{|c|}{ Test for subgroup differences: $C \mathrm{i}^{2}=0.02, \mathrm{df}=\mathrm{I}(\mathrm{P}=0.89), \mathrm{I}^{2}=0.0 \%$} \\
\hline & & & & -4 & 2 & 4 & \\
\hline \multicolumn{8}{|c|}{ Favours Education $\quad$ Favours Controls } \\
\hline
\end{tabular}

\section{Analysis 2.I. Comparison 2 Information Only versus Controls, Outcome I Pain.}

Review: Patient education for adults with rheumatoid arthritis

Comparison: 2 Information Only versus Controls

Outcome: I Pain

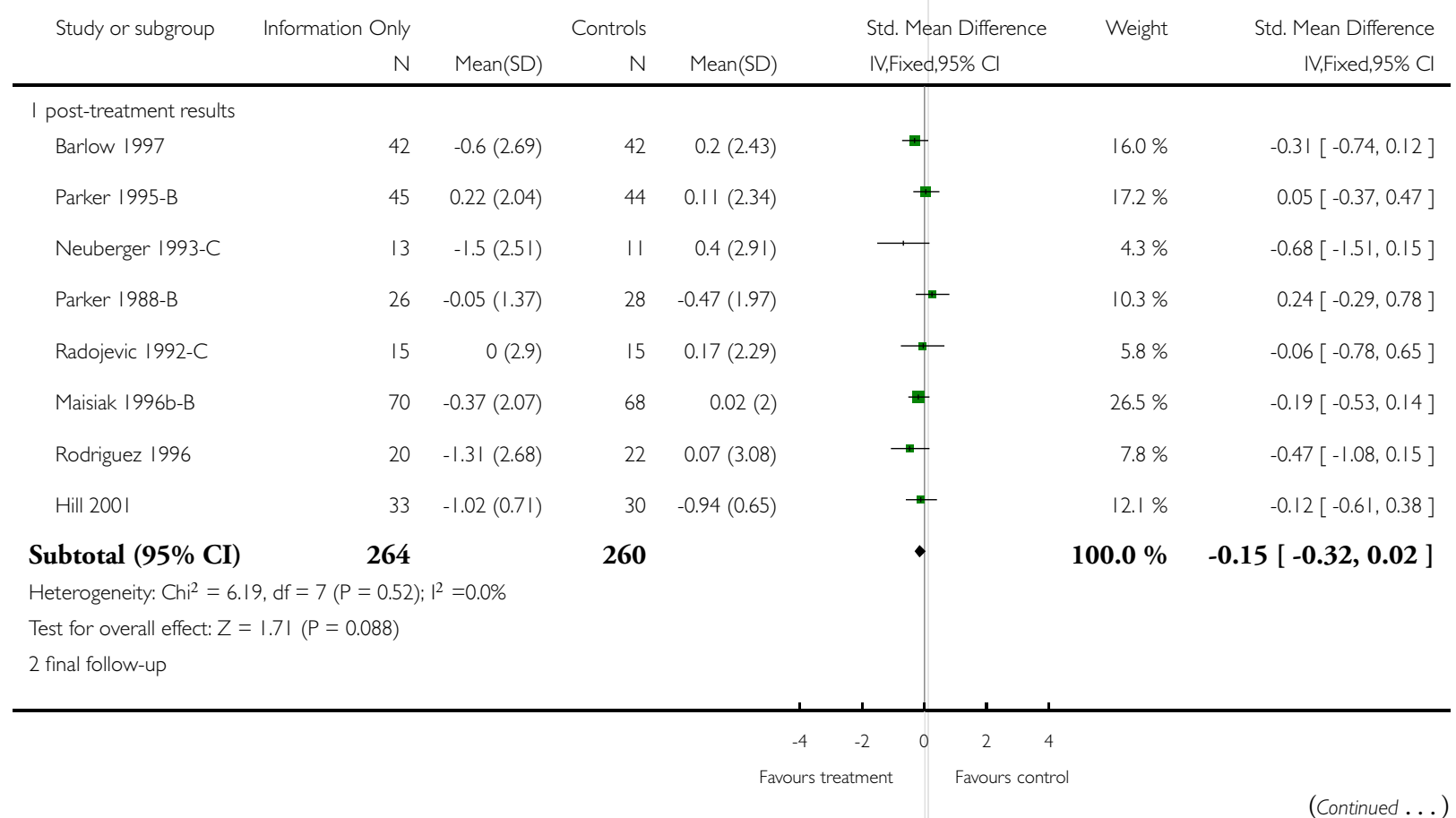




\begin{tabular}{|c|c|c|c|c|c|c|c|}
\hline \multirow[t]{2}{*}{ Study or subgroup } & \multirow{2}{*}{$\begin{array}{r}\text { Information Only } \\
\mathrm{N}\end{array}$} & \multicolumn{3}{|c|}{ Controls } & \multirow{2}{*}{$\begin{array}{l}\text { Std. Mean Difference } \\
\text { IV,Fixed,95\% Cl }\end{array}$} & \multirow[t]{2}{*}{ Weight } & \multirow{2}{*}{$\begin{array}{r}\text { (... Continued }) \\
\text { Std. Mean Difference } \\
\text { IV,Fixed,95\% Cl }\end{array}$} \\
\hline & & Mean(SD) & $\mathrm{N}$ & Mean(SD) & & & \\
\hline Parker 1995-B & 40 & $0.58(2.08)$ & 39 & $-0.04(2.32)$ & 世 & $34.4 \%$ & $0.28[-0.16,0.72]$ \\
\hline Parker 1988-B & 26 & $0.83(1.43)$ & 28 & $0.2(2.09)$ & 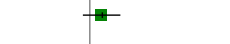 & $23.3 \%$ & $0.34[-0.19,0.88]$ \\
\hline Radojevic 1992-C & 15 & $-0.3(2.79)$ & 15 & $0.14(2.15)$ & $\rightarrow$ & $13.1 \%$ & $-0.17[-0.89,0.55]$ \\
\hline Helliwell 1999 & 40 & $-4.67(21.49)$ & 29 & $2.03(16.47)$ & $\because$ & $29.1 \%$ & $-0.34[-0.82,0.14]$ \\
\hline Subtotal $(95 \% \mathrm{CI})$ & 121 & & 111 & & $\rightarrow$ & $100.0 \%$ & $0.05[-0.21,0.31]$ \\
\hline \multicolumn{8}{|c|}{ Heterogeneity: $\mathrm{Chi}^{2}=5.04, \mathrm{df}=3(\mathrm{P}=0.17) ; \mathrm{I}^{2}=41 \%$} \\
\hline \multicolumn{8}{|c|}{ Test for overall effect: $Z=0.4 \mathrm{I}(P=0.68)$} \\
\hline \multicolumn{8}{|c|}{ Test for subgroup differences: $\mathrm{Chi}^{2}=1.66, \mathrm{df}=\mathrm{I}(\mathrm{P}=0.20), \mathrm{I}^{2}=40 \%$} \\
\hline & & & & -7 & -2 & & \\
\hline \multicolumn{8}{|c|}{ Favours treatment $\quad$ Favours control } \\
\hline
\end{tabular}

\section{Analysis 2.2. Comparison 2 Information Only versus Controls, Outcome 2 Disability.}

Review: Patient education for adults with rheumatoid arthritis

Comparison: 2 Information Only versus Controls

Outcome: 2 Disability

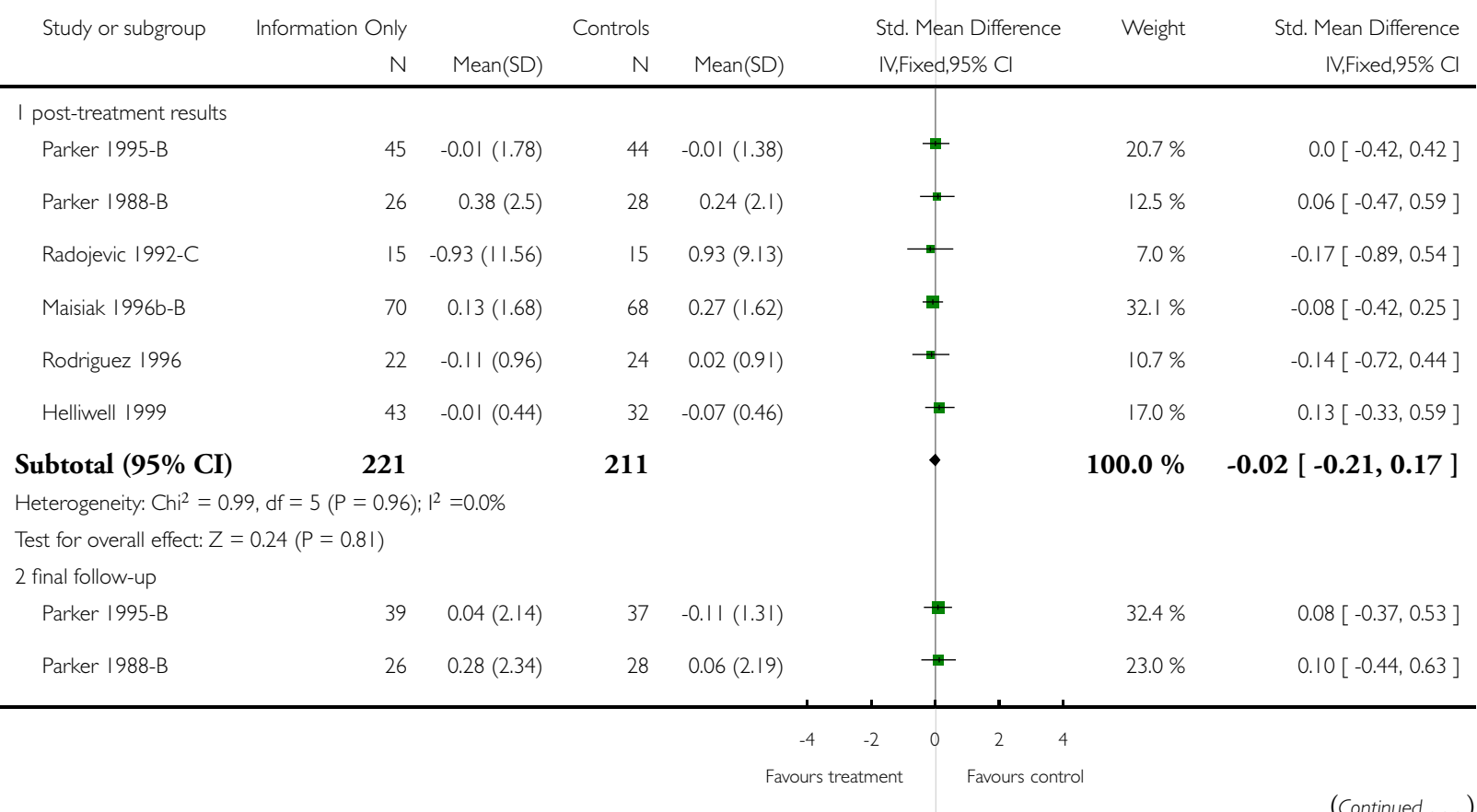




\begin{tabular}{|c|c|c|c|c|c|c|c|}
\hline \multirow[t]{2}{*}{ Study or subgroup } & \multirow{2}{*}{$\begin{array}{r}\text { Information Only } \\
\mathrm{N}\end{array}$} & \multicolumn{3}{|c|}{ Controls } & \multirow{2}{*}{$\begin{array}{l}\text { Std. Mean Difference } \\
\text { IV,Fixed,95\% Cl }\end{array}$} & \multirow[t]{2}{*}{ Weight } & \multirow{2}{*}{$\begin{array}{r}\text { (... Continued }) \\
\text { Std. Mean Difference } \\
\text { IV,Fixed,95\% Cl }\end{array}$} \\
\hline & & Mean(SD) & N & Mean(SD) & & & \\
\hline Radojevic 1992-C & 15 & $0.07(11.72)$ & 15 & $-0.22(8.96)$ & $\longrightarrow$ & $12.8 \%$ & $0.03[-0.69,0.74]$ \\
\hline Helliwell 1999 & 43 & $-0.03(0.37)$ & 33 & $0.05(0.45)$ & H & $31.8 \%$ & $-0.19[-0.65,0.26]$ \\
\hline Subtotal $(95 \% \mathrm{CI})$ & 123 & & 113 & & $\rightarrow$ & $100.0 \%$ & $-0.01[-0.27,0.25]$ \\
\hline \multicolumn{8}{|c|}{ Heterogeneity: Chi $^{2}=0.96, d f=3(P=0.81) ; I^{2}=0.0 \%$} \\
\hline \multicolumn{8}{|c|}{ Test for overall effect: $Z=0.07(P=0.94)$} \\
\hline \multicolumn{8}{|c|}{ Test for subgroup differences: $\mathrm{Chi}^{2}=0.0 \mathrm{I}, \mathrm{df}=\mathrm{I}(\mathrm{P}=0.93), \mathrm{I}^{2}=0.0 \%$} \\
\hline & & & & -4 & -2 & 4 & \\
\hline \multicolumn{8}{|c|}{ Favours treatment $\quad$ Favours control } \\
\hline
\end{tabular}

\section{Analysis 2.3. Comparison 2 Information Only versus Controls, Outcome 3 Joint Counts.}

Review: Patient education for adults with rheumatoid arthritis

Comparison: 2 Information Only versus Controls

Outcome: 3 Joint Counts

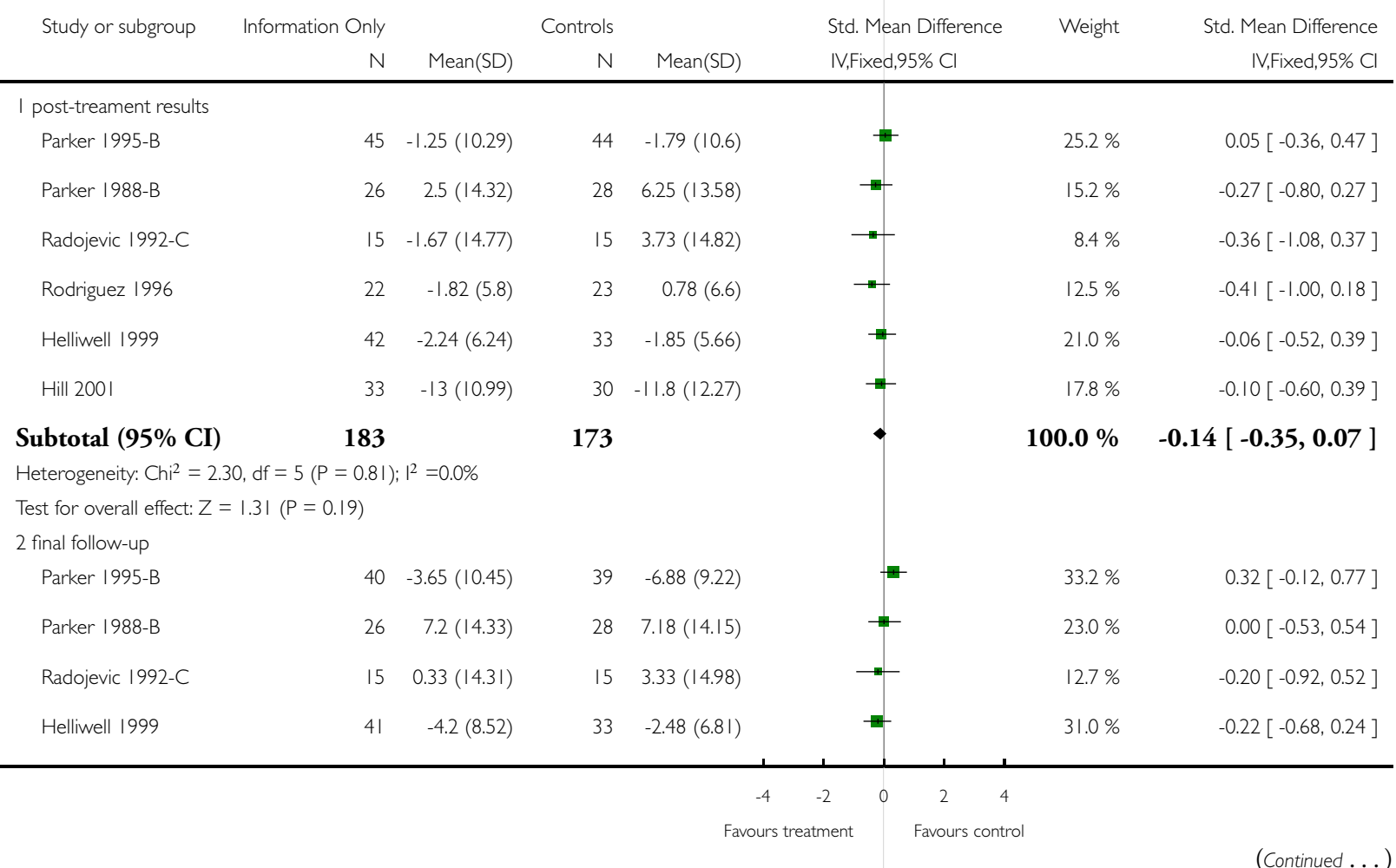




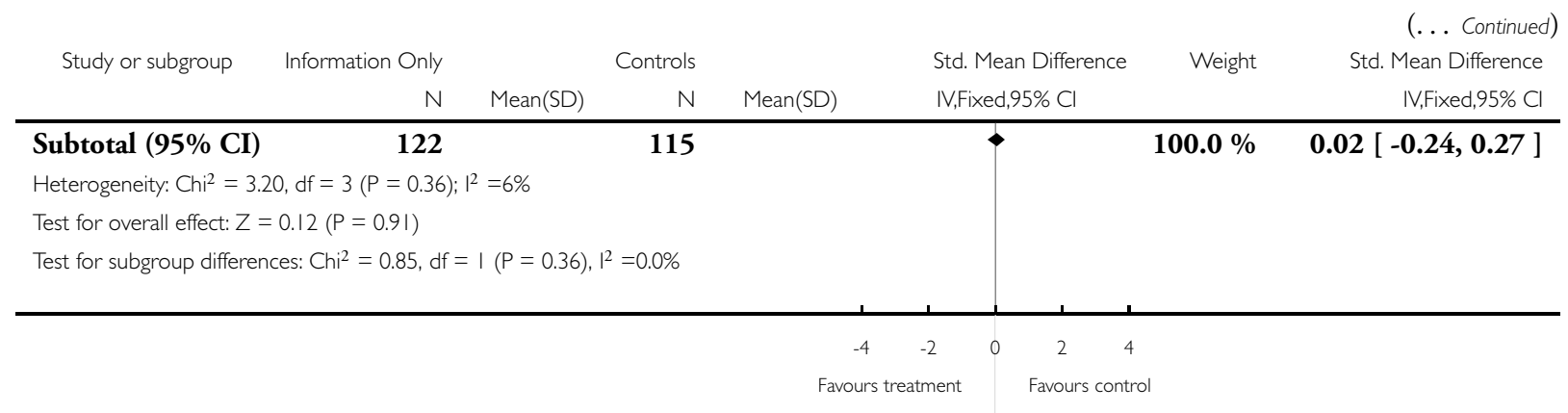

\section{Analysis 2.4. Comparison 2 Information Only versus Controls, Outcome 4 Patient Global Assessment.}

Review: Patient education for adults with rheumatoid arthritis

Comparison: 2 Information Only versus Controls

Outcome: 4 Patient Global Assessment

\begin{tabular}{|c|c|c|c|c|c|c|c|}
\hline \multirow[t]{2}{*}{ Study or subgroup } & Information Only & \multicolumn{3}{|c|}{ Controls } & \multirow{2}{*}{$\begin{array}{l}\text { Std. Mean Difference } \\
\text { IV,Fixed,95\% Cl }\end{array}$} & \multirow[t]{2}{*}{ Weight } & \multirow{2}{*}{$\begin{array}{r}\text { Std. Mean Difference } \\
\text { IV,Fixed,95\% Cl }\end{array}$} \\
\hline & $N$ & Mean(SD) & $\mathrm{N}$ & Mean(SD) & & & \\
\hline \multicolumn{8}{|l|}{ I post-treatment results } \\
\hline Parker 1988-B & 26 & $-0.05(2.08)$ & 28 & $0.38(1.95)$ & & $100.0 \%$ & $-0.21[-0.75,0.32]$ \\
\hline Subtotal $(95 \% \mathrm{CI})$ & 26 & & 28 & & & $100.0 \%$ & $-0.21[-0.75,0.32]$ \\
\hline \multicolumn{8}{|c|}{ Heterogeneity: not applicable } \\
\hline \multicolumn{8}{|c|}{ Test for overall effect: $Z=0.77(P=0.44)$} \\
\hline \multicolumn{8}{|l|}{2 final follow-up } \\
\hline Parker 1988-B & 26 & $0.09(2.04)$ & 28 & $0.06(2.16)$ & & $43.9 \%$ & $0.01[-0.52,0.55]$ \\
\hline Helliwell 1999 & 42 & $-6.24(14.97)$ & 30 & $-0.9(13.74)$ & ت1 & $56.1 \%$ & $-0.36[-0.84,0.11]$ \\
\hline Subtotal (95\% CI) & 68 & & 58 & & 4 & $100.0 \%$ & $-0.20[-0.55,0.16]$ \\
\hline \multicolumn{8}{|c|}{ Heterogeneity: $\mathrm{Chi}^{2}=1.09, \mathrm{df}=\mathrm{I}(\mathrm{P}=0.30) ; \mathrm{I}^{2}=8 \%$} \\
\hline \multicolumn{8}{|c|}{ Test for overall effect: $Z=1.10(P=0.27)$} \\
\hline \multicolumn{8}{|c|}{ Test for subgroup differences: $\mathrm{Chi}^{2}=0.00, \mathrm{df}=\mathrm{I}(\mathrm{P}=0.97), \mathrm{I}^{2}=0.0 \%$} \\
\hline & & & & & -2 & & \\
\hline & & & & Favour & Favours cc & & \\
\hline
\end{tabular}


Analysis 2.6. Comparison 2 Information Only versus Controls, Outcome 6 Psychological Status.

Review: Patient education for adults with rheumatoid arthritis

Comparison: 2 Information Only versus Controls

Outcome: 6 Psychological Status

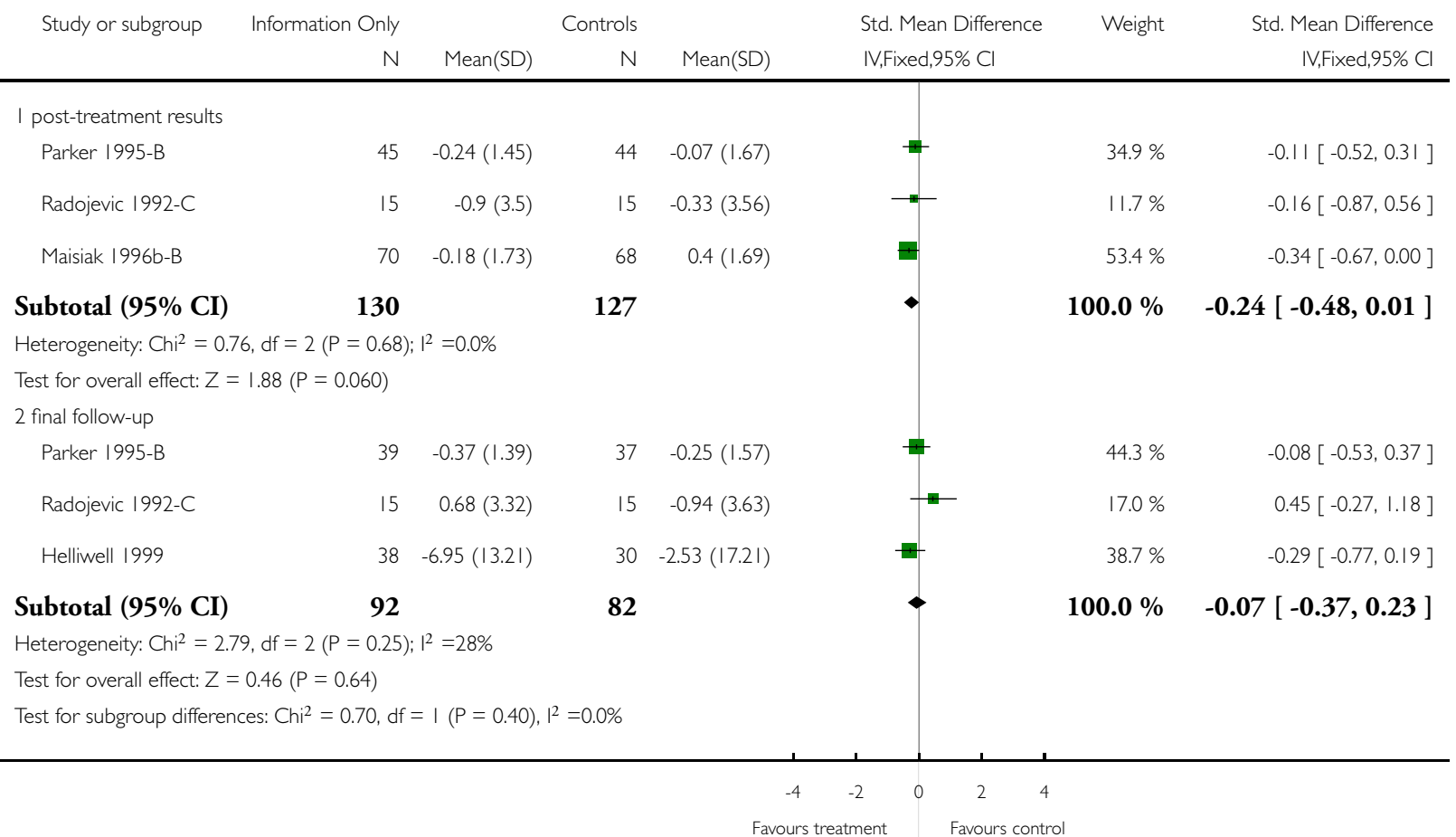




\section{Analysis 2.7. Comparison 2 Information Only versus Controls, Outcome 7 Anxiety.}

Review: Patient education for adults with rheumatoid arthritis

Comparison: 2 Information Only versus Controls

Outcome: 7 Anxiety

Controls

Mean(SD)

Std. Mean Difference

Weight

Std. Mean Difference

N Mean(SD) IV,Fixed,95\% Cl

IV,Fixed,95\% Cl

I post-treatment results

Barlow 1997

$42 \quad 0.38(2.38)$

$0.16(2.81)$

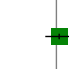

Parker 1995-B

$45-1.23(9.08)$

$-1.21(9.24)$

Parker 1988-B

$26 \quad 0.01(1.87)$

$8-0.15(1.88)$

113

114

Subtotal (95\% CI)

$=0.95) ;\left.\right|^{2}=0.0 \%$

Heterogeneity: $\mathrm{Chi}^{2}=0.10, \mathrm{df}=2(P=0.95$
Test for overall effect: $Z=0.38(P=0.7 \mathrm{I})$

2 final follow-up

$\begin{array}{lllll}\text { Parker 1995-B } & 40 & -1.66(8.06) & 39 & -1.61(9.41) \\ \text { Parker 1988-B } & 26 & -0.03(1.92) & 28 & 0.03(1.83)\end{array}$

67

Subtotal (95\% CI)

66

Heterogeneity: $\mathrm{Chi}^{2}=0.0 \mathrm{I}, \mathrm{df}=\mathrm{I}(\mathrm{P}=0.94) ; \mathrm{I}^{2}=0.0 \%$

Test for overall effect: $Z=0.09(P=0.93)$

Test for subgroup differences: $\mathrm{Chi}^{2}=0.09, \mathrm{df}=\mathrm{I}(\mathrm{P}=0.76), \mathrm{I}^{2}=0.0 \%$

$40.6 \%$

$-0.03[-0.57,0.50]$

$100.0 \% \quad-0.02[-0.36,0.32]$

$37.0 \%$

$0.08[-0.34,0.51]$

$39.2 \%$

$0.00[-0.42,0.41]$

$23.8 \%$

$0.05[-0.21,0.31]$

$100.0 \%$

Favours treatment 


\section{Analysis 2.8. Comparison 2 Information Only versus Controls, Outcome 8 Depression.}

Review: Patient education for adults with rheumatoid arthritis

Comparison: 2 Information Only versus Controls

Outcome: 8 Depression

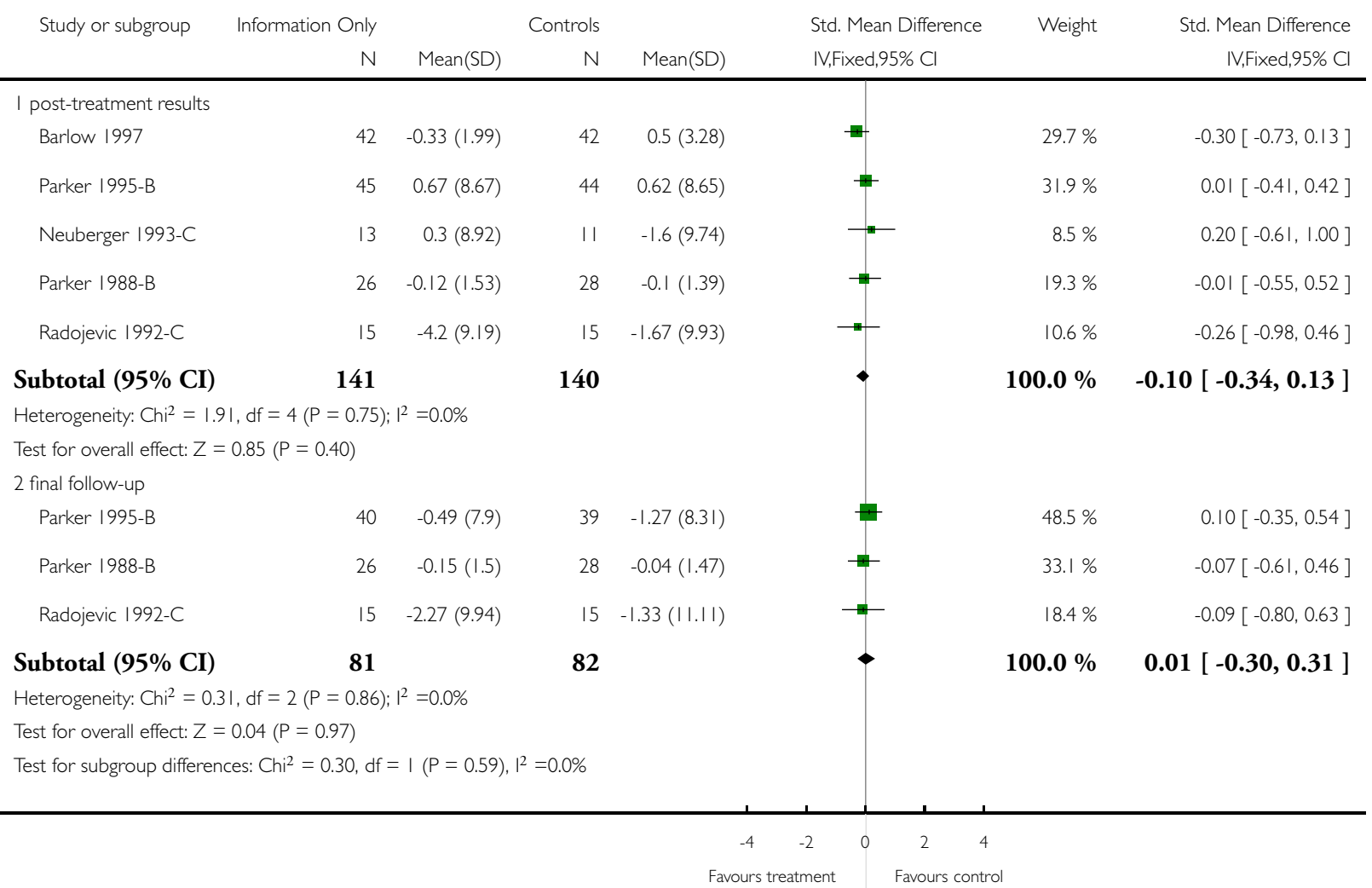




\section{Analysis 2.9. Comparison 2 Information Only versus Controls, Outcome 9 Disease Activity.}

Review: Patient education for adults with rheumatoid arthritis

Comparison: 2 Information Only versus Controls

Outcome: 9 Disease Activity

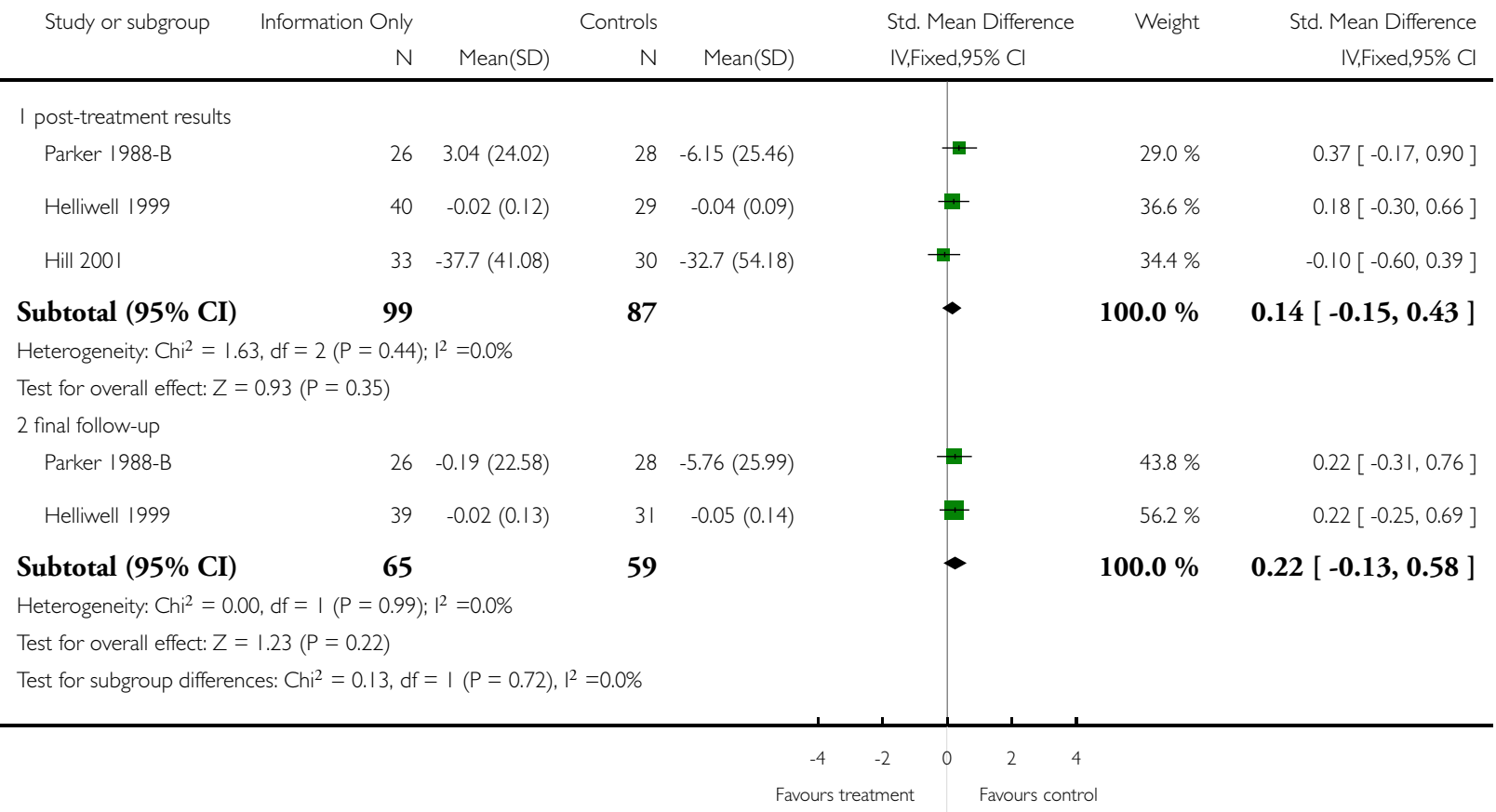


Analysis 3.I. Comparison 3 Counselling versus Controls, Outcome I Pain.

Review: Patient education for adults with rheumatoid arthritis

Comparison: 3 Counselling versus Controls

Outcome: | Pain

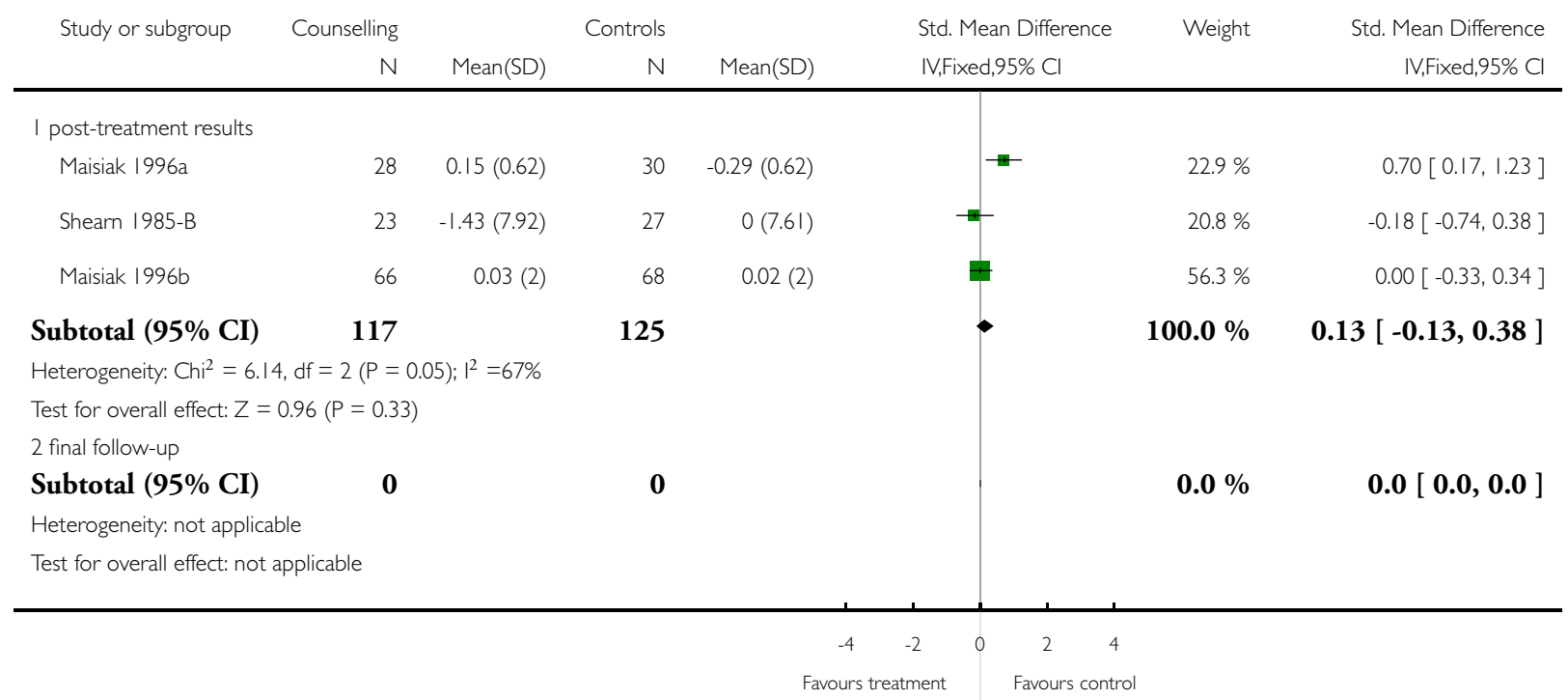




\section{Analysis 3.2. Comparison 3 Counselling versus Controls, Outcome 2 Disability.}

Review: Patient education for adults with rheumatoid arthritis

Comparison: 3 Counselling versus Controls

Outcome: 2 Disability

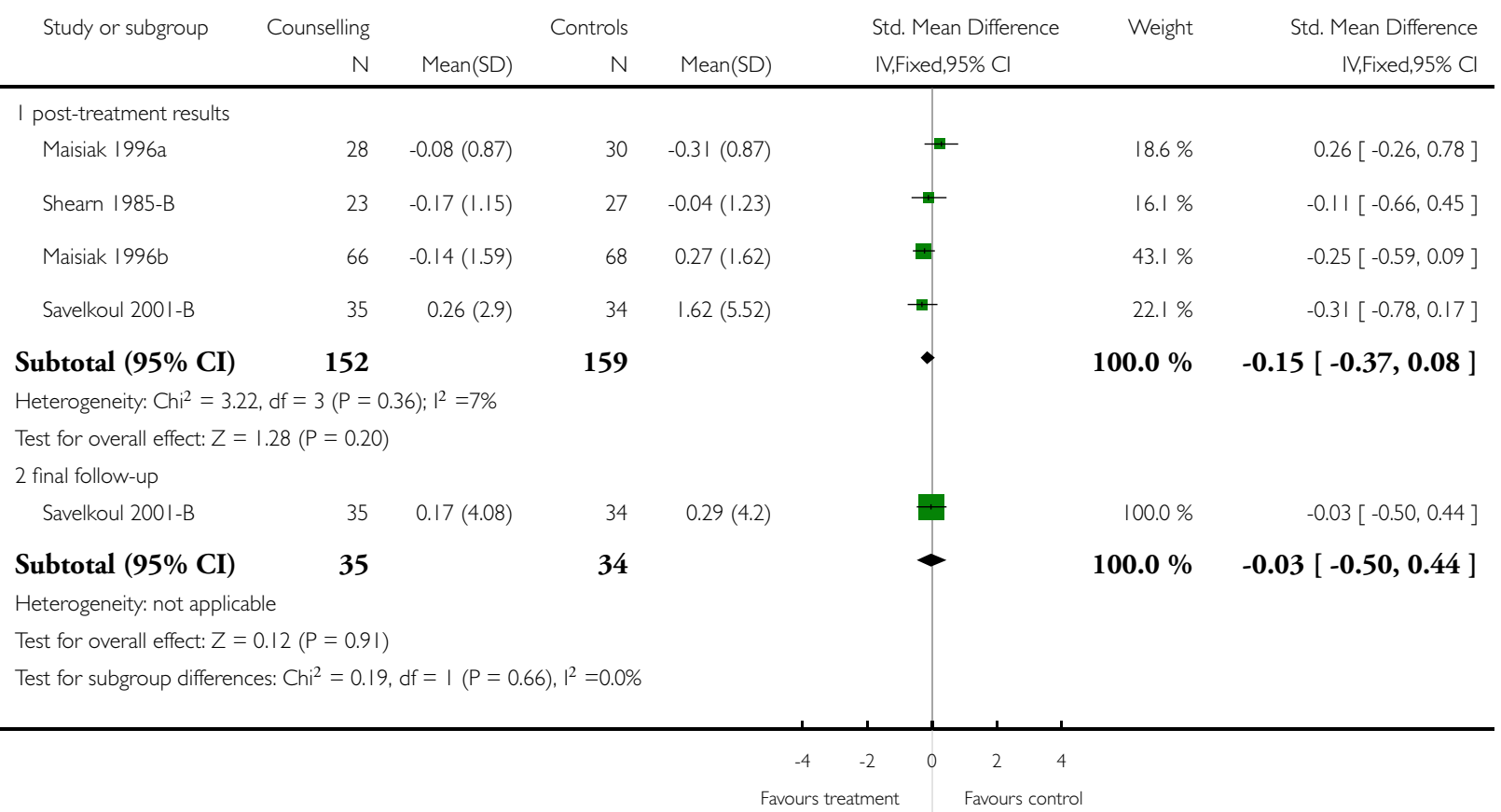




\section{Analysis 3.3. Comparison 3 Counselling versus Controls, Outcome 3 Joint Counts.}

Review: Patient education for adults with rheumatoid arthritis

Comparison: 3 Counselling versus Controls

Outcome: 3 Joint Counts

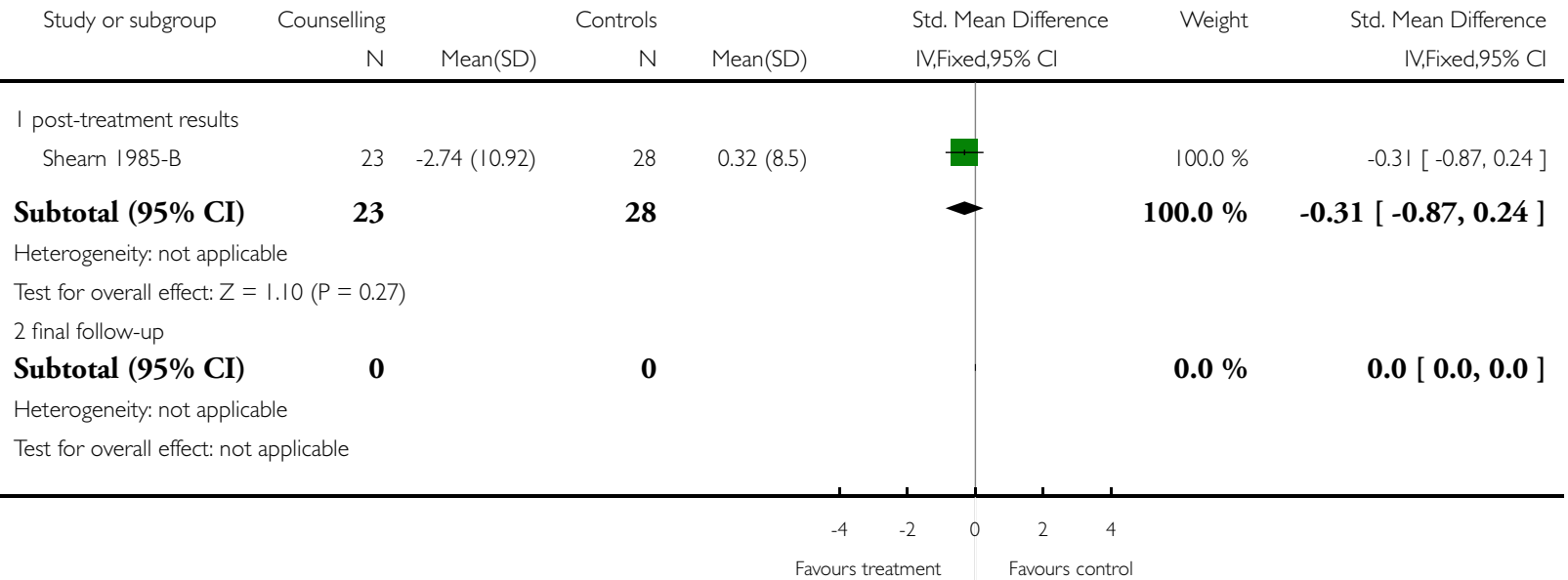

\section{Analysis 3.4. Comparison 3 Counselling versus Controls, Outcome 4 Patient Global Assessment.}

Review: Patient education for adults with rheumatoid arthritis

Comparison: 3 Counselling versus Controls

Outcome: 4 Patient Global Assessment

\begin{tabular}{|c|c|c|c|c|c|c|c|c|}
\hline \multirow[t]{2}{*}{ Study or subgroup } & Counselling & \multicolumn{3}{|c|}{ Controls } & \multirow{2}{*}{\multicolumn{2}{|c|}{$\begin{array}{l}\text { Std. Mean Difference } \\
\text { IV,Fixed,95\% Cl }\end{array}$}} & \multirow[t]{2}{*}{ Weight } & \multirow{2}{*}{$\begin{array}{r}\text { Std. Mean Difference } \\
\text { IV,Fixed,95\% Cl }\end{array}$} \\
\hline & $\mathrm{N}$ & Mean(SD) & $\mathrm{N}$ & Mean(SD) & & & & \\
\hline \multicolumn{9}{|l|}{ I post-treatment results } \\
\hline Savelkoul 200I-B & 34 & $0(0.6)$ & 34 & $0.21(0.81)$ & & & $100.0 \%$ & $-0.29[-0.77,0.19]$ \\
\hline Subtotal (95\% CI) & 34 & & 34 & & & & $100.0 \%$ & $-0.29[-0.77,0.19]$ \\
\hline \multicolumn{9}{|c|}{ Heterogeneity: not applicable } \\
\hline \multicolumn{9}{|c|}{ Test for overall effect: $Z=1.19(P=0.23)$} \\
\hline \multicolumn{9}{|l|}{2 final follow-up } \\
\hline Savelkoul 200I-B & 34 & $0.09(0.57)$ & 34 & $-0.06(0.69)$ & & & $100.0 \%$ & $0.23[-0.24,0.71]$ \\
\hline Subtotal (95\% CI) & 34 & & 34 & & & $\mathbf{-}$ & $100.0 \%$ & $0.23[-0.24,0.71]$ \\
\hline \multicolumn{9}{|c|}{ Heterogeneity: not applicable } \\
\hline \multicolumn{9}{|c|}{ Test for overall effect: $Z=0.96(P=0.34)$} \\
\hline \multicolumn{9}{|c|}{ Test for subgroup differences: $\mathrm{Chi}^{2}=2.33, \mathrm{df}=\mathrm{I}(\mathrm{P}=0.13), \mathrm{I}^{2}=57 \%$} \\
\hline & & & & -4 & -2 & 4 & & \\
\hline \multicolumn{9}{|c|}{ Favours treatment } \\
\hline
\end{tabular}




\section{Analysis 3.6. Comparison 3 Counselling versus Controls, Outcome 6 Psychological Status.}

Review: Patient education for adults with rheumatoid arthritis

Comparison: 3 Counselling versus Controls

Outcome: 6 Psychological Status

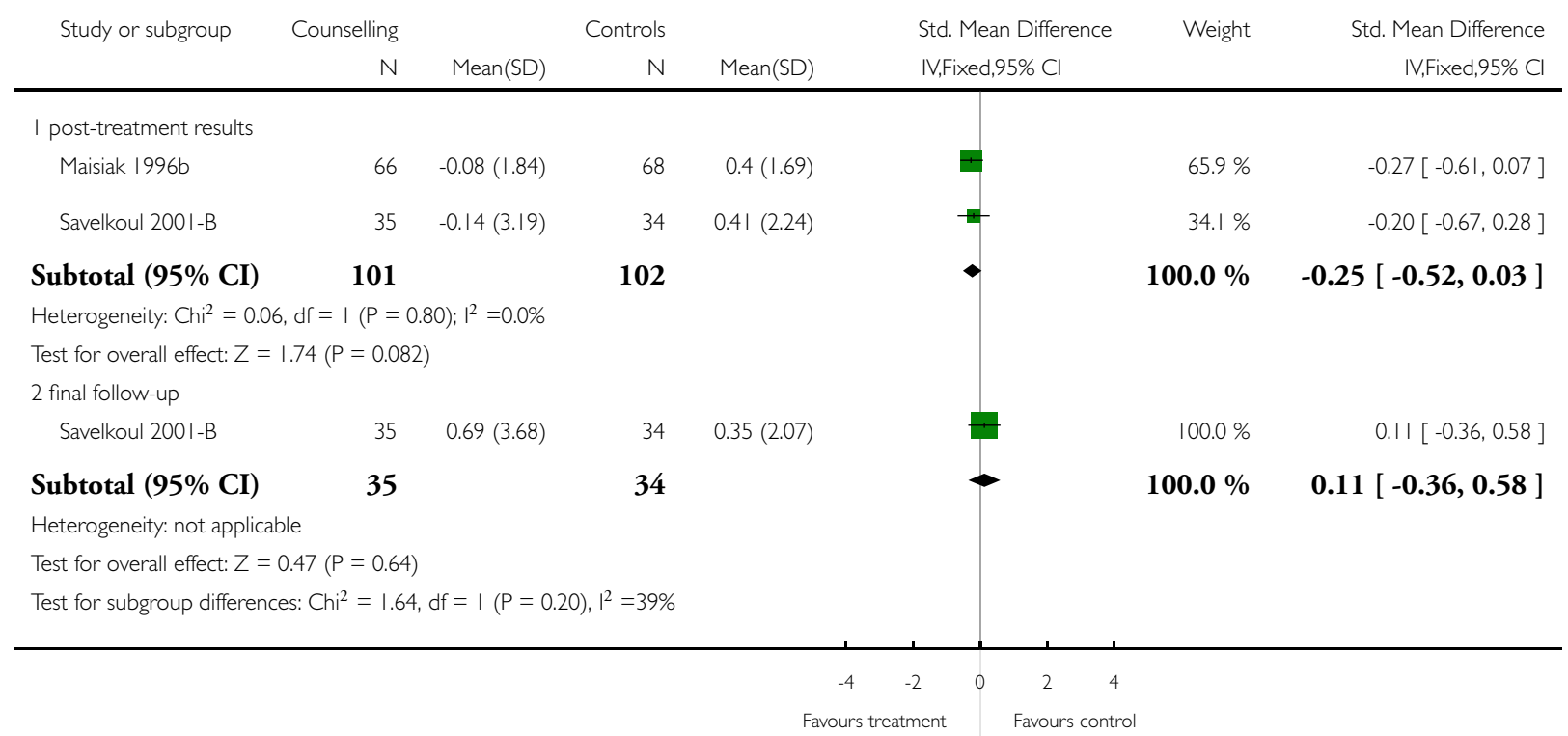




\section{Analysis 3.7. Comparison 3 Counselling versus Controls, Outcome 7 Anxiety.}

Review: Patient education for adults with rheumatoid arthritis

Comparison: 3 Counselling versus Controls

Outcome: 7 Anxiety

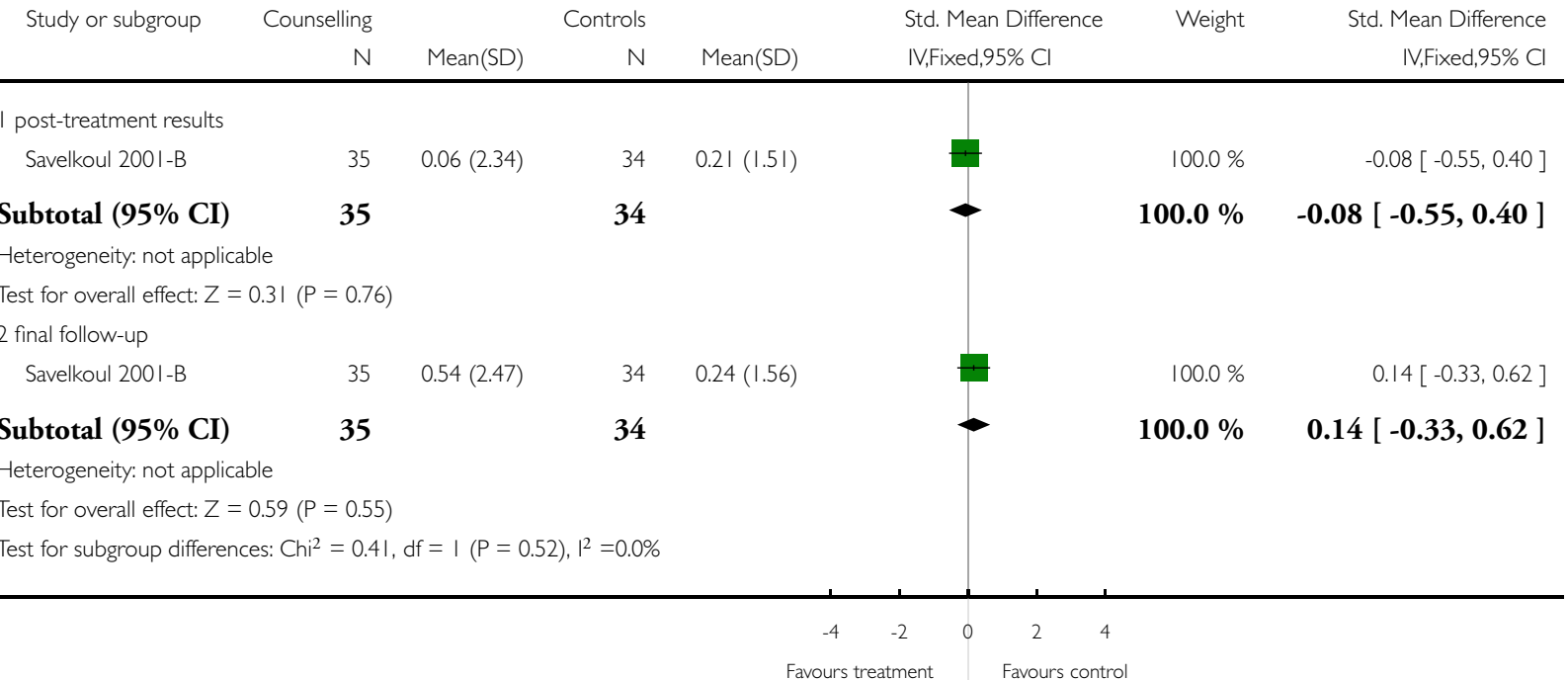




\section{Analysis 3.8. Comparison 3 Counselling versus Controls, Outcome 8 Depression.}

Review: Patient education for adults with rheumatoid arthritis

Comparison: 3 Counselling versus Controls

Outcome: 8 Depression

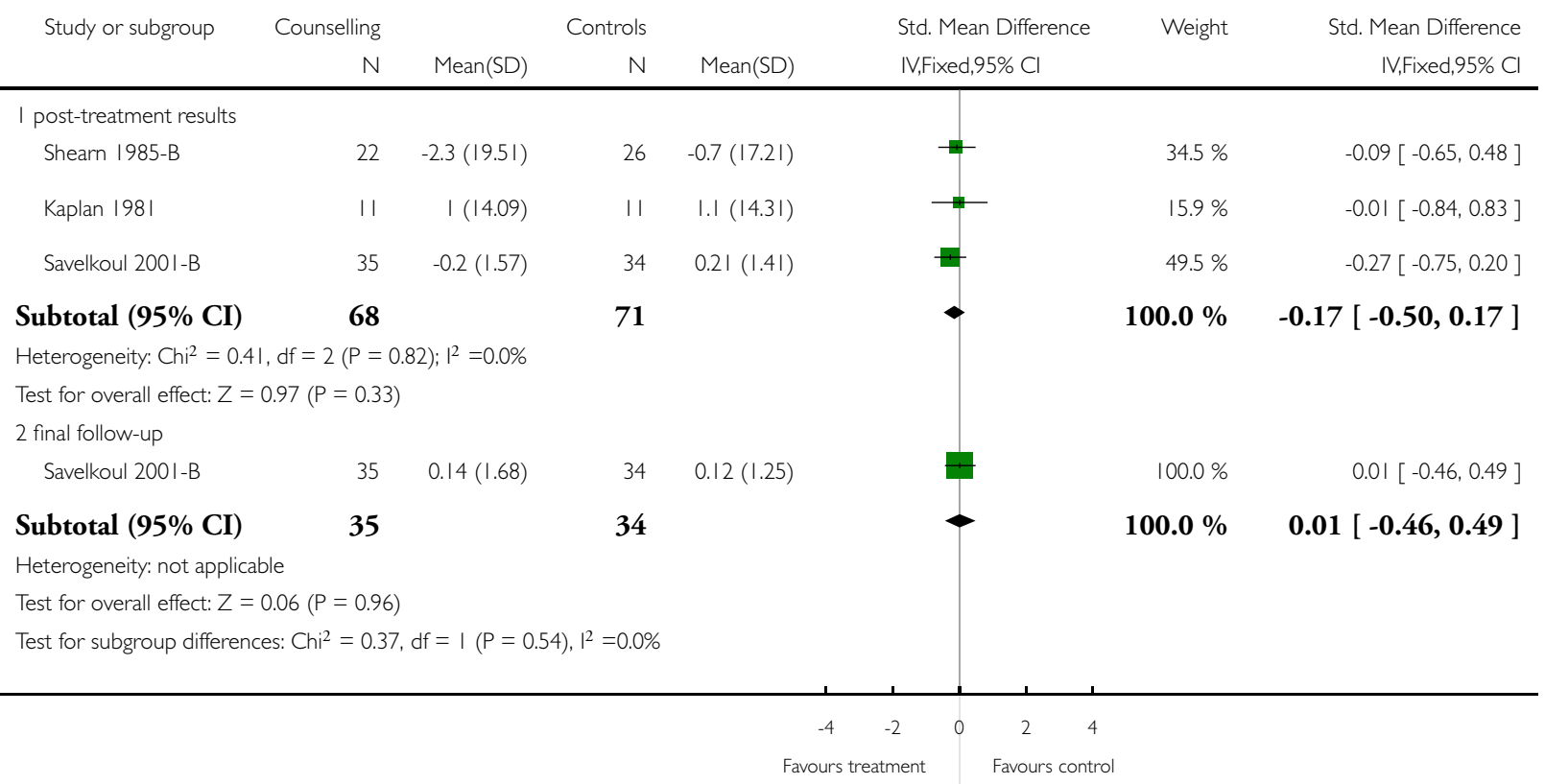




\section{Analysis 3.9. Comparison 3 Counselling versus Controls, Outcome 9 Disease Activity.}

Review: Patient education for adults with rheumatoid arthritis

Comparison: 3 Counselling versus Controls

Outcome: 9 Disease Activity

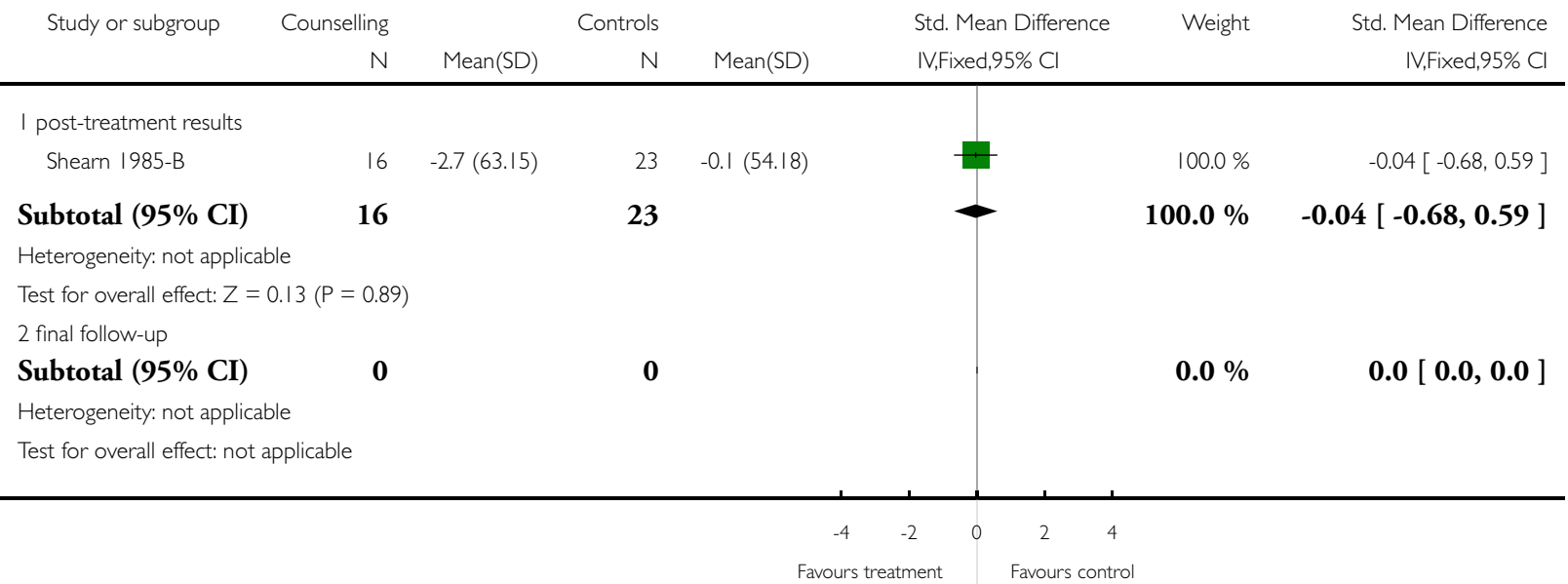

\section{Analysis 4.I. Comparison 4 Behavioural Treatment versus Controls, Outcome I Pain.}

Review: Patient education for adults with rheumatoid arthritis

Comparison: 4 Behavioural Treatment versus Controls

Outcome: I Pain

Study or subgroup Behavioral Treatment $\quad$ Controls $\quad$ Std. Mean Difference Weight $\quad$ Std. Mean Difference

N Mean(SD) N Mean(SD) IV,Fixed,95\% Cl IV,Fixed,95\% Cl

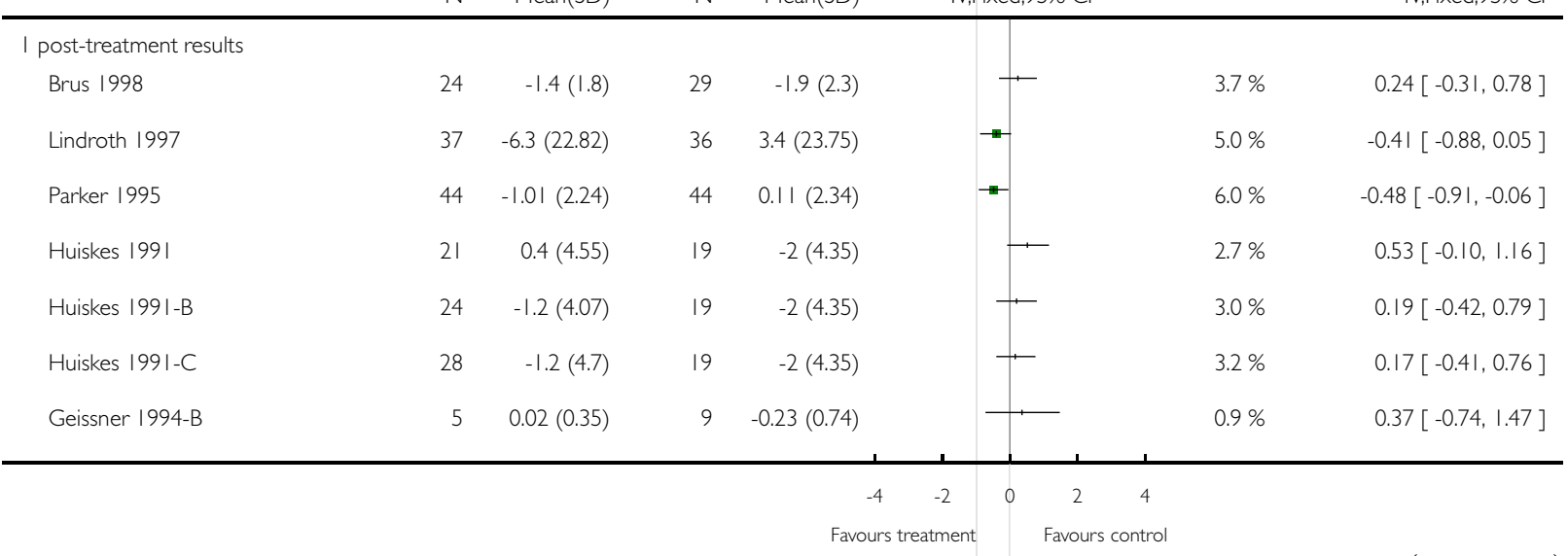

(Continued ....) 


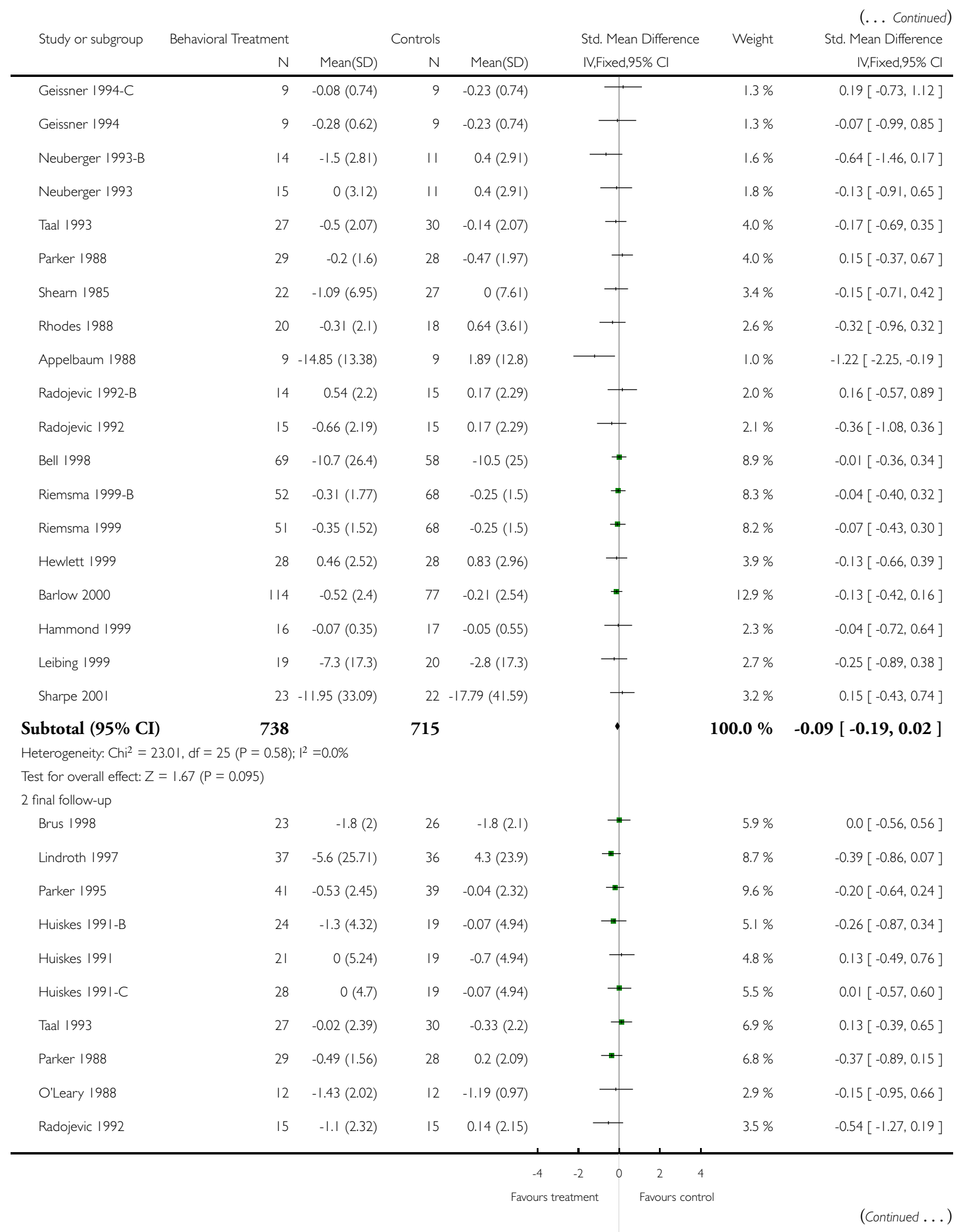

Patient education for adults with rheumatoid arthritis (Review)

Copyright (־ 2009 The Cochrane Collaboration. Published by John Wiley \& Sons, Ltd. 


\begin{tabular}{|c|c|c|c|c|c|c|c|}
\hline \multirow[t]{2}{*}{ Study or subgroup } & Behavioral Treatment & \multicolumn{3}{|c|}{ Controls } & \multirow{2}{*}{$\begin{array}{l}\text { Std. Mean Differen } \\
\text { IV,Fixed,95\% Cl }\end{array}$} & \multirow[t]{2}{*}{ Weight } & $\begin{array}{l}\text { (... Continued) } \\
\text { Std. Mean Difference }\end{array}$ \\
\hline & $N$ & Mean(SD) & $N$ & Mean(SD) & & & IV,Fixed,95\% Cl \\
\hline Radojevic 1992-B & 14 & $-0.64(2.46)$ & 15 & $0.14(2.15)$ & $\longrightarrow$ & $3.5 \%$ & $-0.33[-1.06,0.41]$ \\
\hline Riemsma 1999-B & 48 & $-0.45(1.5)$ & 63 & $-0.38(1.82)$ & + & $13.2 \%$ & $-0.04[-0.42,0.33]$ \\
\hline Riemsma 1999 & 42 & $0.05(1.8)$ & 63 & $-0.38(1.82)$ & $\mp$ & $12.1 \%$ & $0.24[-0.16,0.63]$ \\
\hline Hewlett 1999 & 25 & $0.04(2.98)$ & 26 & $0.44(1.92)$ & $\rightarrow$ & $6.2 \%$ & $-0.16[-0.7 \mid, 0.39]$ \\
\hline Sharpe 200I & 23 & $-10.9(30.6)$ & 22 & $-2.5(47.89)$ & $\rightarrow$ & $5.4 \%$ & $-0.21[-0.79,0.38]$ \\
\hline Subtotal (95\% CI) & 409 & & 432 & & $\bullet$ & $100.0 \%$ & $-0.11[-0.24,0.03]$ \\
\hline \multicolumn{8}{|c|}{ Heterogeneity: $\mathrm{Chi}^{2}=9.49, \mathrm{df}=14(\mathrm{P}=0.80) ;\left.\right|^{2}=0.0 \%$} \\
\hline \multicolumn{8}{|c|}{ Test for overall effect: $Z=1.55(P=0.12)$} \\
\hline \multicolumn{8}{|c|}{ Test for subgroup differences: $\mathrm{Chi}^{2}=0.05, \mathrm{df}=\mathrm{I}(\mathrm{P}=0.82), \mathrm{I}^{2}=0.0 \%$} \\
\hline & & & & & -2 & 4 & \\
\hline
\end{tabular}

\section{Analysis 4.2. Comparison 4 Behavioural Treatment versus Controls, Outcome 2 Disability.}

Review: Patient education for adults with rheumatoid arthritis

Comparison: 4 Behavioural Treatment versus Controls

Outcome: 2 Disability

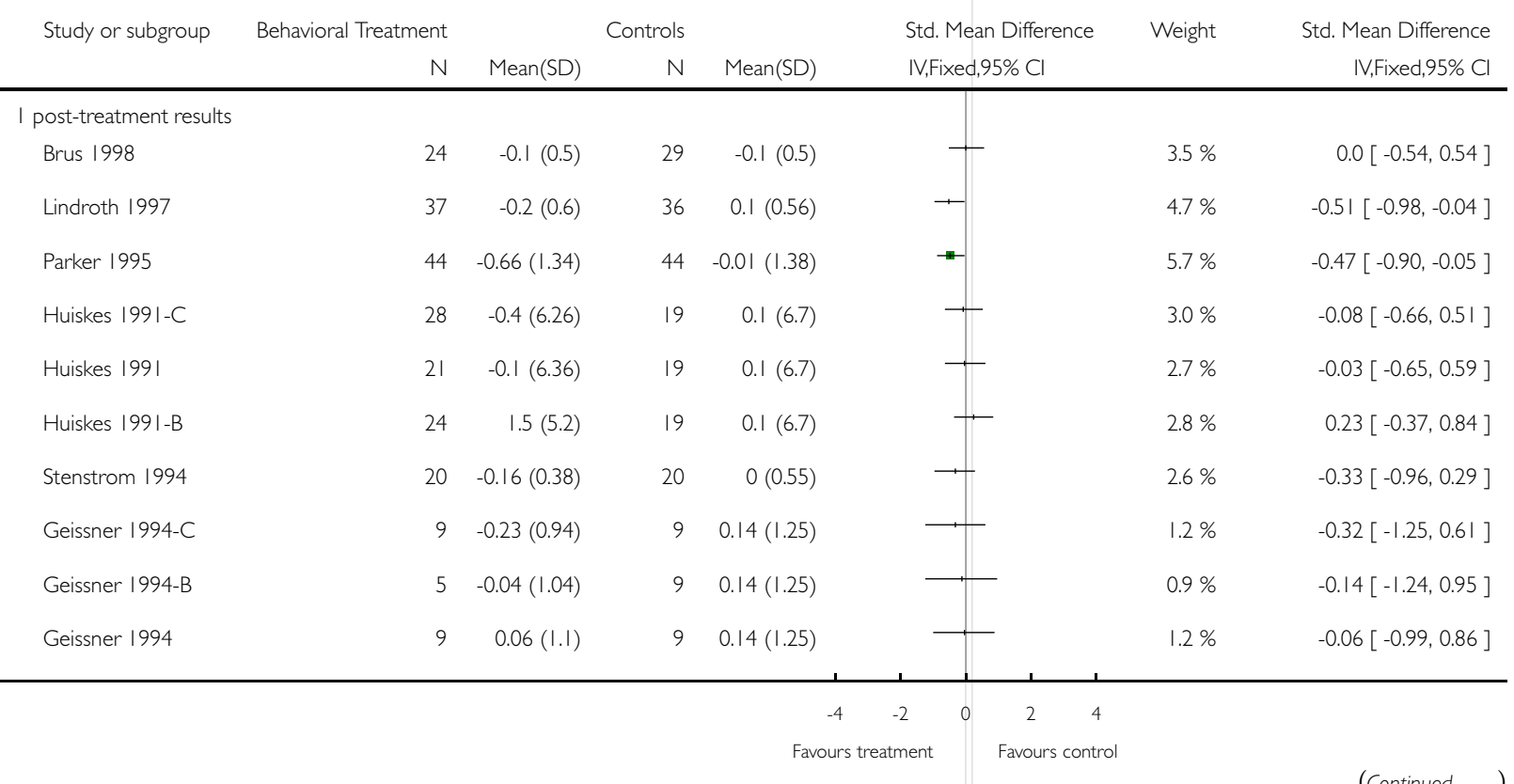




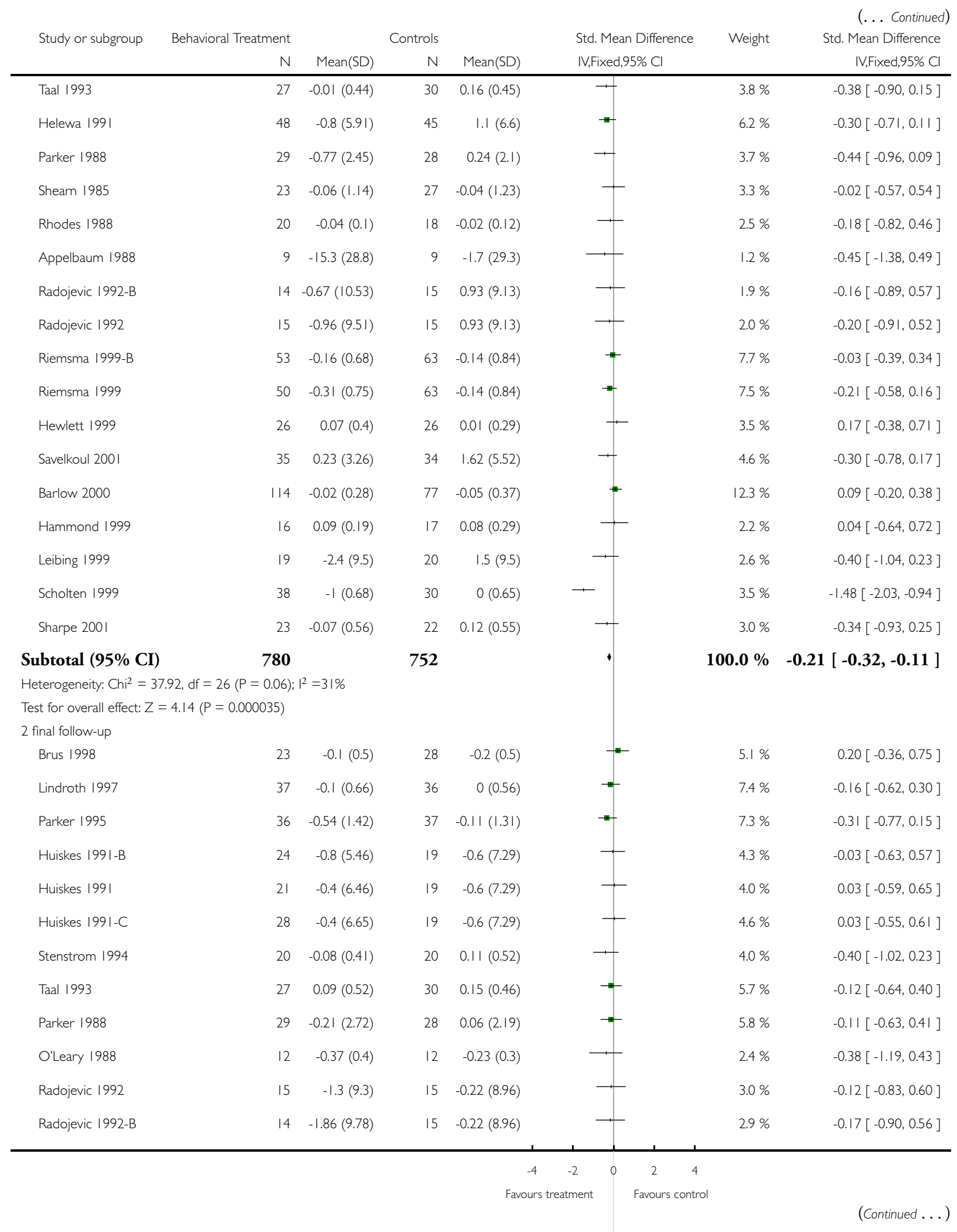

Patient education for adults with rheumatoid arthritis (Review)

Copyright (־ 2009 The Cochrane Collaboration. Published by John Wiley \& Sons, Ltd. 


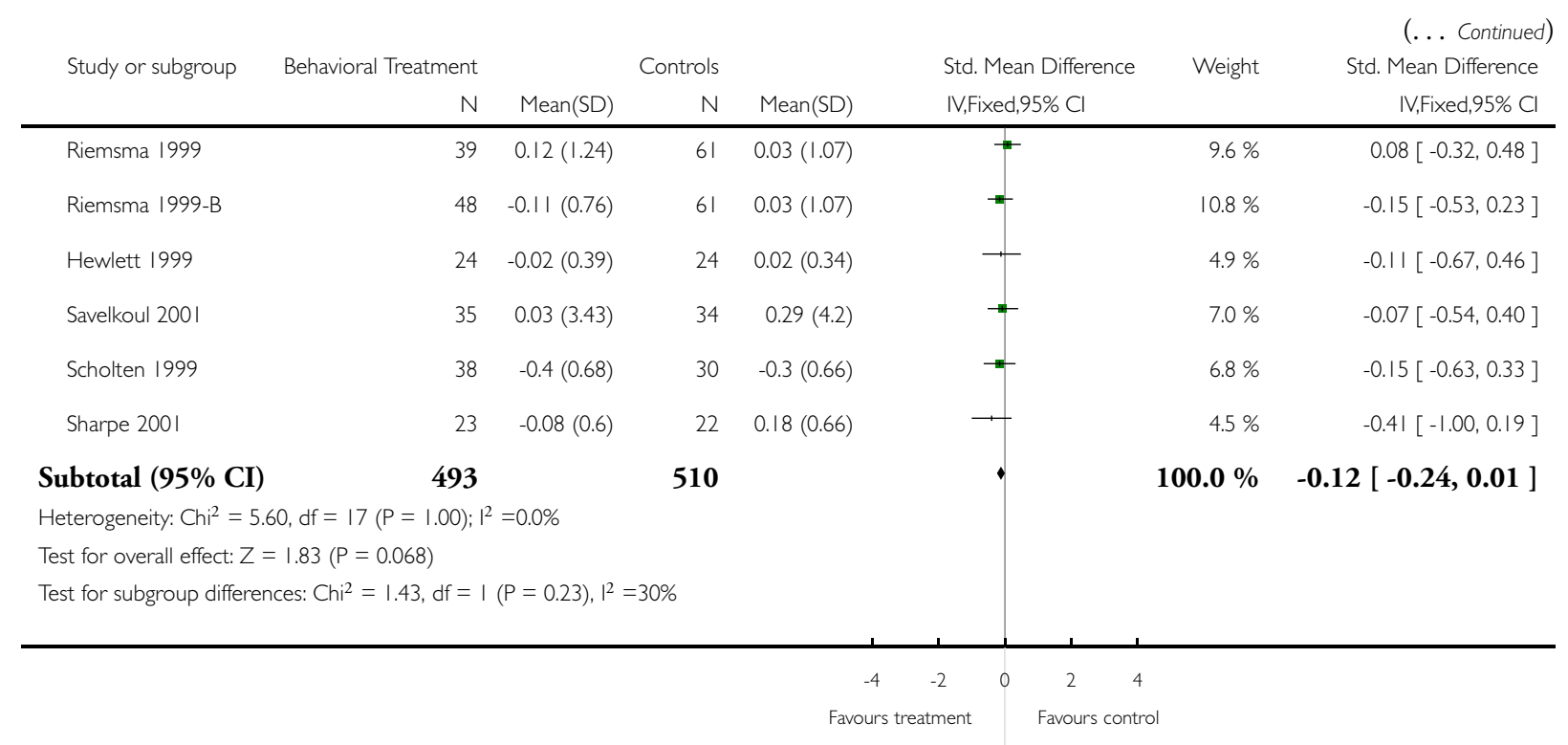

\section{Analysis 4.3. Comparison 4 Behavioural Treatment versus Controls, Outcome 3 Joint Counts.}

Review: Patient education for adults with rheumatoid arthritis

Comparison: 4 Behavioural Treatment versus Controls

Outcome: 3 Joint Counts

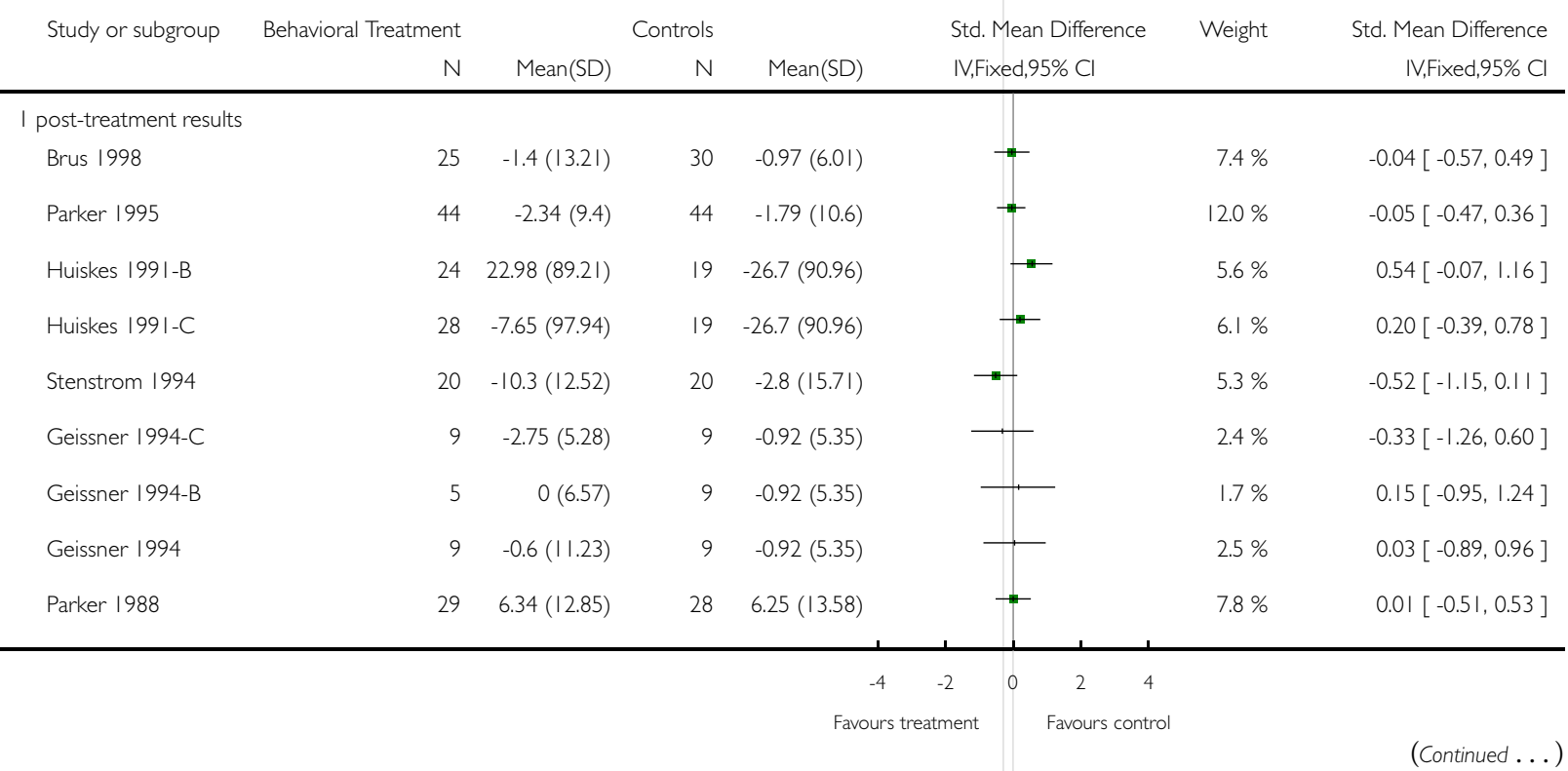




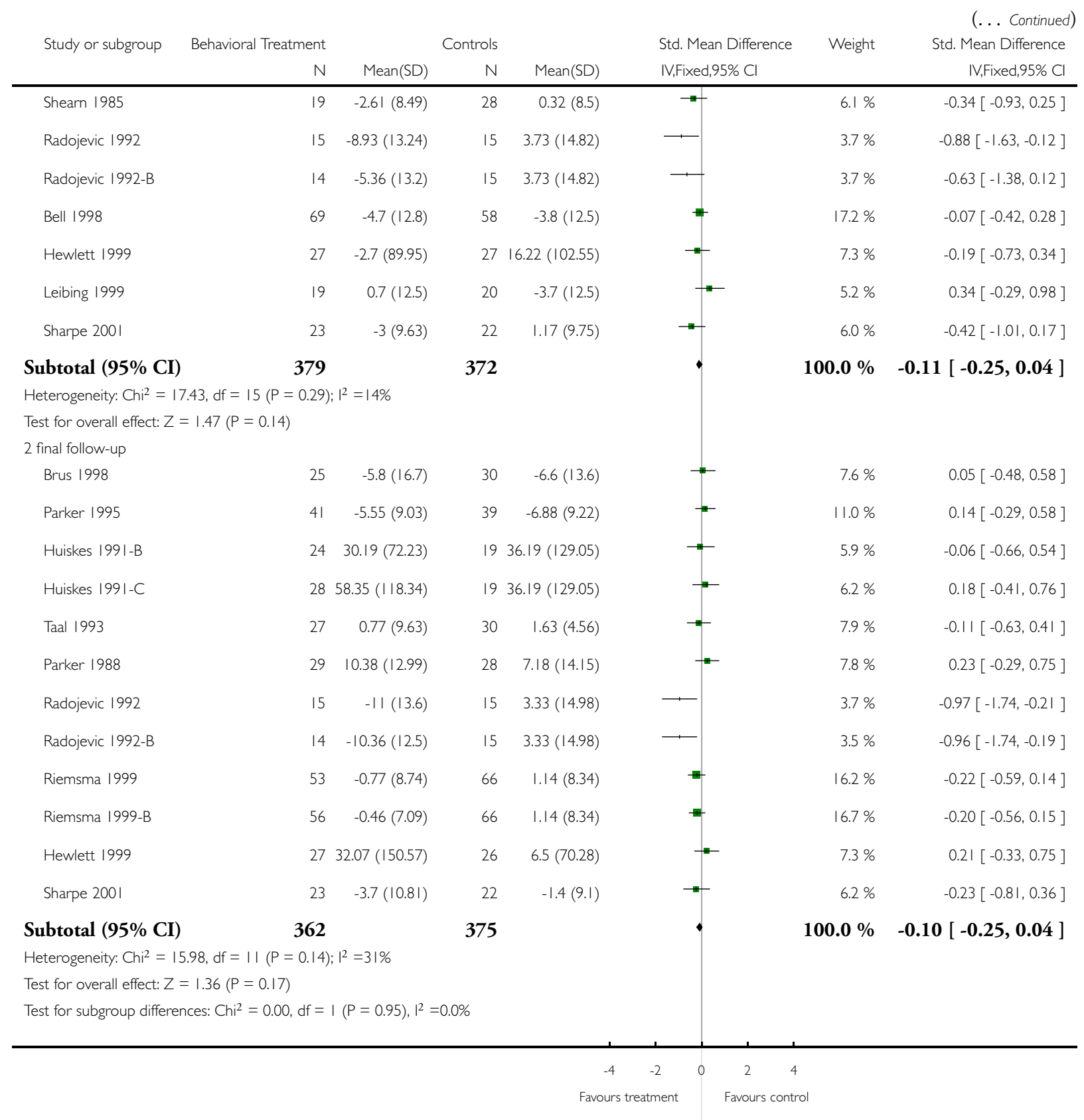




\section{Analysis 4.4. Comparison 4 Behavioural Treatment versus Controls, Outcome 4 Patient Global Assessment.}

Review: Patient education for adults with rheumatoid arthritis

Comparison: 4 Behavioural Treatment versus Controls

Outcome: 4 Patient Global Assessment

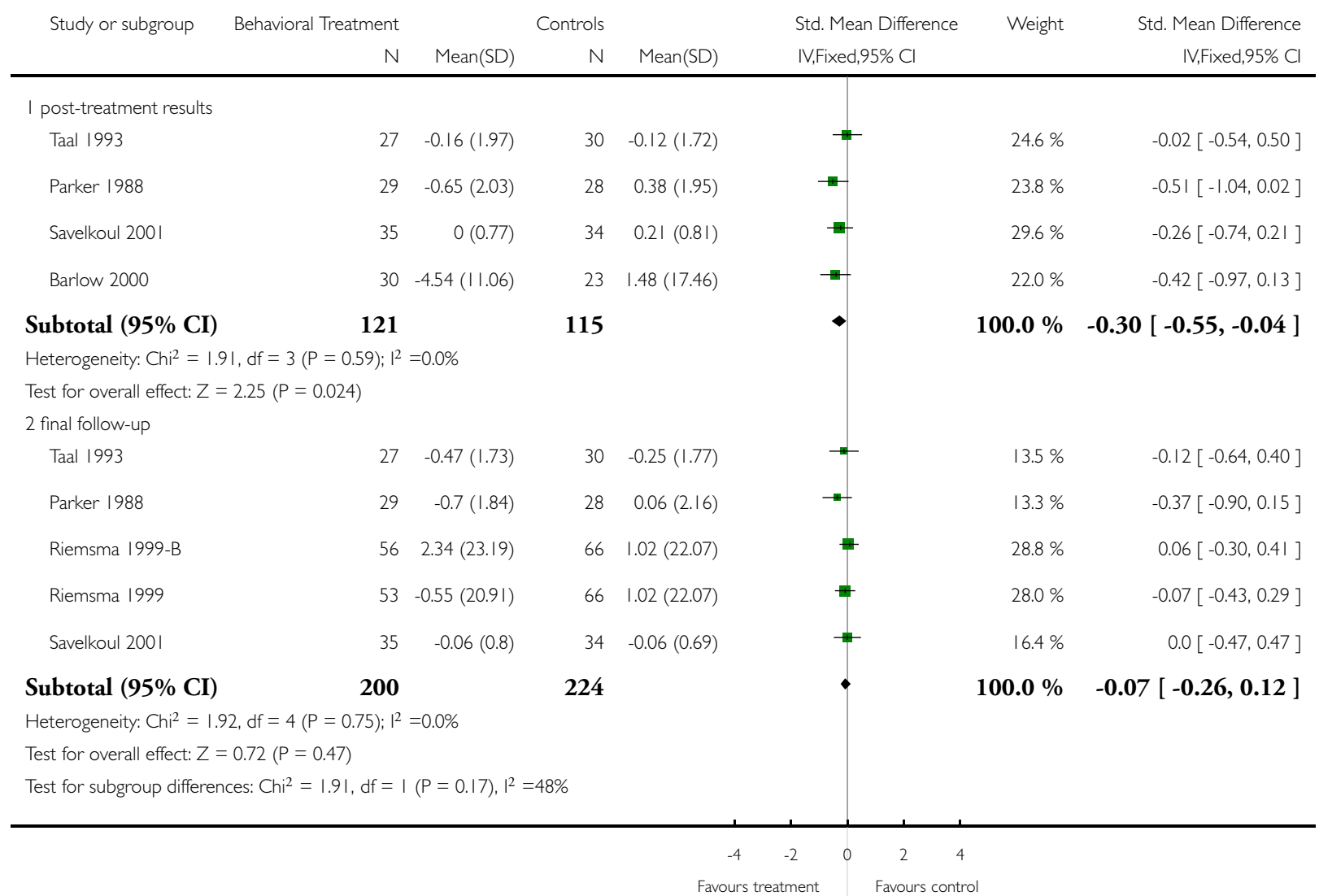


Analysis 4.6. Comparison 4 Behavioural Treatment versus Controls, Outcome 6 Psychological Status.

Review: Patient education for adults with rheumatoid arthritis

Comparison: 4 Behavioural Treatment versus Controls

Outcome: 6 Psychological Status

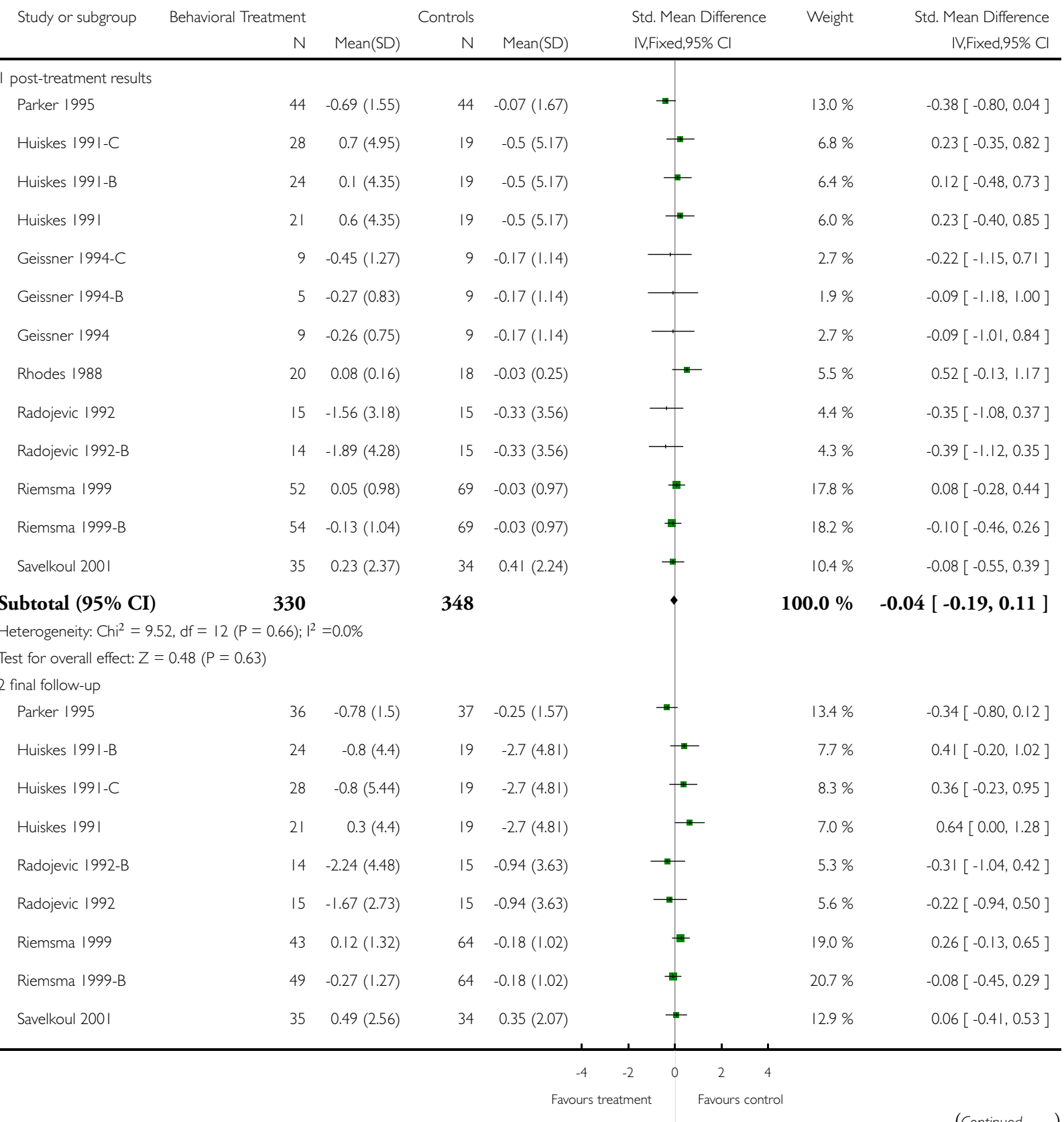

(Continued ...) 


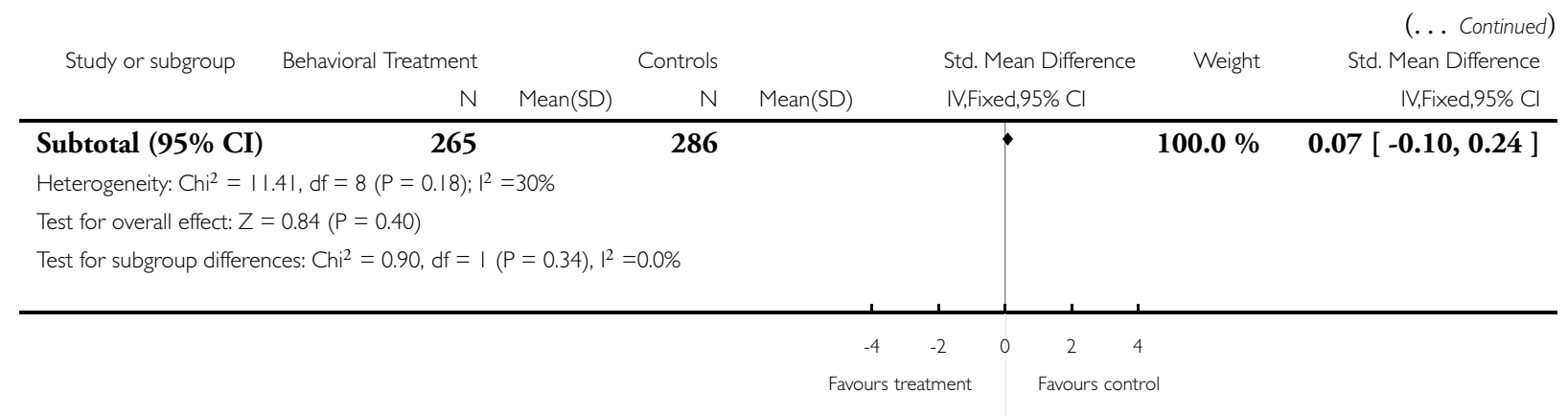

\section{Analysis 4.7. Comparison 4 Behavioural Treatment versus Controls, Outcome 7 Anxiety.}

Review: Patient education for adults with rheumatoid arthritis

Comparison: 4 Behavioural Treatment versus Controls

Outcome: 7 Anxiety

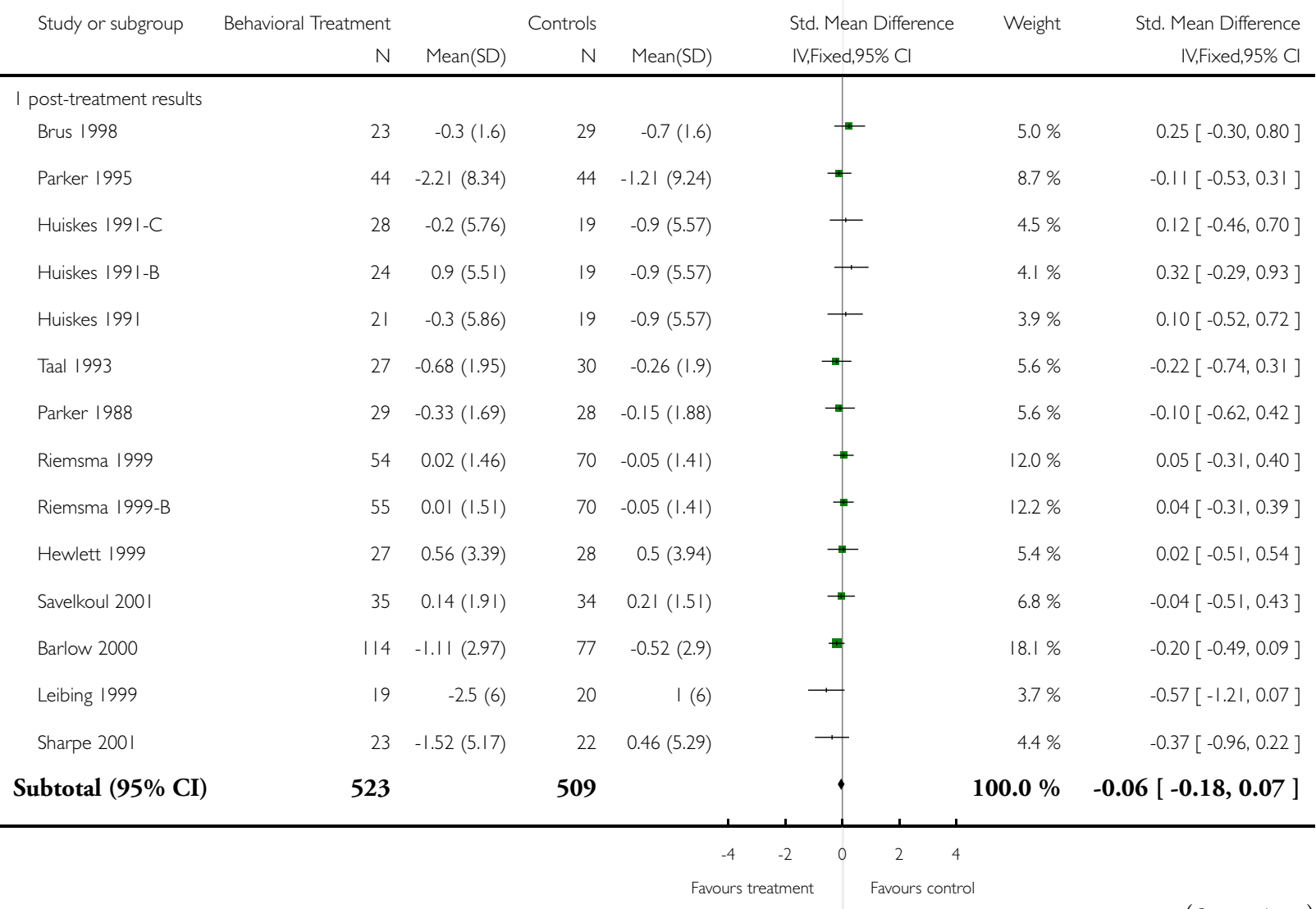

(Continued ...) 


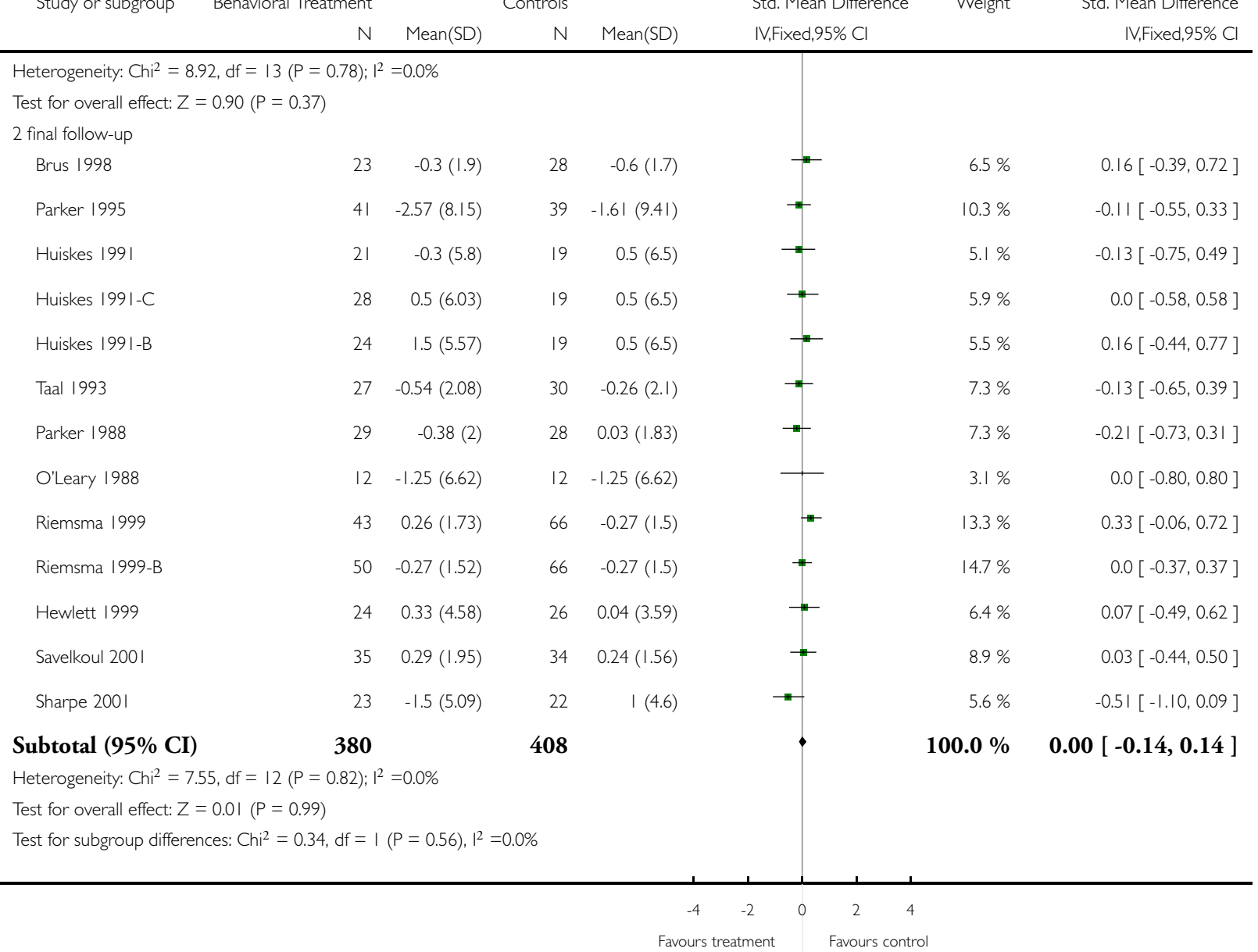




\section{Analysis 4.8. Comparison 4 Behavioural Treatment versus Controls, Outcome 8 Depression.}

Review: Patient education for adults with rheumatoid arthritis

Comparison: 4 Behavioural Treatment versus Controls

Outcome: 8 Depression

Study or subgroup Behavioral Treatment

Mean(SD)

Controls

Std. Mean Difference

Weight

Std. Mean Difference

I post-treatment results

$-\mathrm{N} \quad \operatorname{Mean}(\mathrm{SD})$

IV,Fixed,95\% C

IV,Fixed,95\% Cl

Brus 1998

$24-0.4(1.4)$

$-0.5(1.6)$

Parker 1995

Huiskes 1991-C

$44-3.21(8.24)$

Huiskes 1991

Huiskes |99|-B

$28 \quad-1.2(4.11)$

$21 \quad-0.8(5.17)$

Neuberger 1993

Neuberger 1993-B

$24 \quad$ I.I (3.06)

$15 \quad-0.7(5.67)$

Taal 1993

$14 \quad-2.5(8.45)$

Helewa 1991

$27-0.58(1.45)$

Parker 1988

$49-2(6.56)$

Shearn 1985

$29-0.45(1.4)$

Radojevic 1992

Radojevic 1992-B

$22 \quad 1.3(17.12)$

$15 \quad-0.67(10.89)$

$14 \quad 0.22(12.09)$

Riemsma 1999

Riemsma 1999-B

$54-0.05(1.01)$

Hewlett 1999

$54-0.19(0.94)$

Savelkoul 2001

$27-0.19(1.71)$

$35 \quad 0.09(1.15)$

Barlow 2000

Leibing 1999

$114-1.14(2.98)$

$19-4.6(8.1)$

Scholten 1999

Sharpe 200I

$$
38 \quad-5.2(5.4)
$$

$23-1.04(3.51)$

690

660

Subtotal (95\% CI)

Heterogeneity: $\mathrm{Chi}^{2}=22.84, \mathrm{df}=20(\mathrm{P}=0.30) ; \mathrm{I}^{2}=12 \%$

Test for overall effect: $Z=2.63(P=0.0086)$

2 final follow-up

Brus 1998

$23-0.6(2.2)$

27

$-0.6(1.7)$

$0.62(8.65)$

$-0.7(2.91)$

$9 \quad-0.7(2.91)$

$-0.7(2.91)$

I $\quad-1.6(9.74)$

| - $1.6(9.74)$

$-0.5(1.31)$

$-1.2(7.07)$

$-0.1(1.39)$

$-0.7(17.21)$

$5-1.67(9.93)$

$-1.67(9.93)$

$6901(0.93)$

$0.01(0.93)$

$8.04(4.08)$

$0.21(1.41)$

$7-0.36(2.68)$

20

$-0.7(8.1)$

30

0.2 (6.5)

$22 \quad-1.68(4)$
$4.0 \%$

$0.07[-0.48,0.61]$

$6.5 \%$

$3.4 \%$

$3.0 \%$

$3.1 \%$

$1.9 \%$

$1.9 \%$

$4.3 \%$

$7.1 \%$

$4.3 \%$

$3.6 \%$

$2.3 \%$

$2.2 \%$

$9.2 \%$

$9.1 \%$

$4.2 \%$

$5.2 \%$

$13.8 \%$

$2.9 \%$

$4.6 \%$

$3.4 \%$

$100.0 \%-0.14[-0.25,-0.04]$

$-0.45[-0.87,-0.03]$

$-0.13[-0.72,0.45]$

$-0.02[-0.64,0.60]$

$0.59[-0.03,1.21]$

$0.11[-0.66,0.89]$

$-0.10[-0.89,0.69]$

$-0.06[-0.58,0.46]$

$-0.12[-0.52,0.29]$

$-0.25[-0.77,0.27]$

$0.11[-0.45,0.68]$

$0.09[-0.62,0.81]$

$0.17[-0.56,0.90]$

$-0.06[-0.42,0.29]$

$-0.21[-0.57,0.14]$

$-0.07[-0.60,0.46]$

$-0.09[-0.56,0.38]$

$-0.27[-0.56,0.02]$

$-0.47[-1.11,0.17]$

$-0.90[-1.41,-0.40]$

$0.17[-0.42,0.75]$

(4)

$0.0[-0.56,0.56]$

(Continued....) 


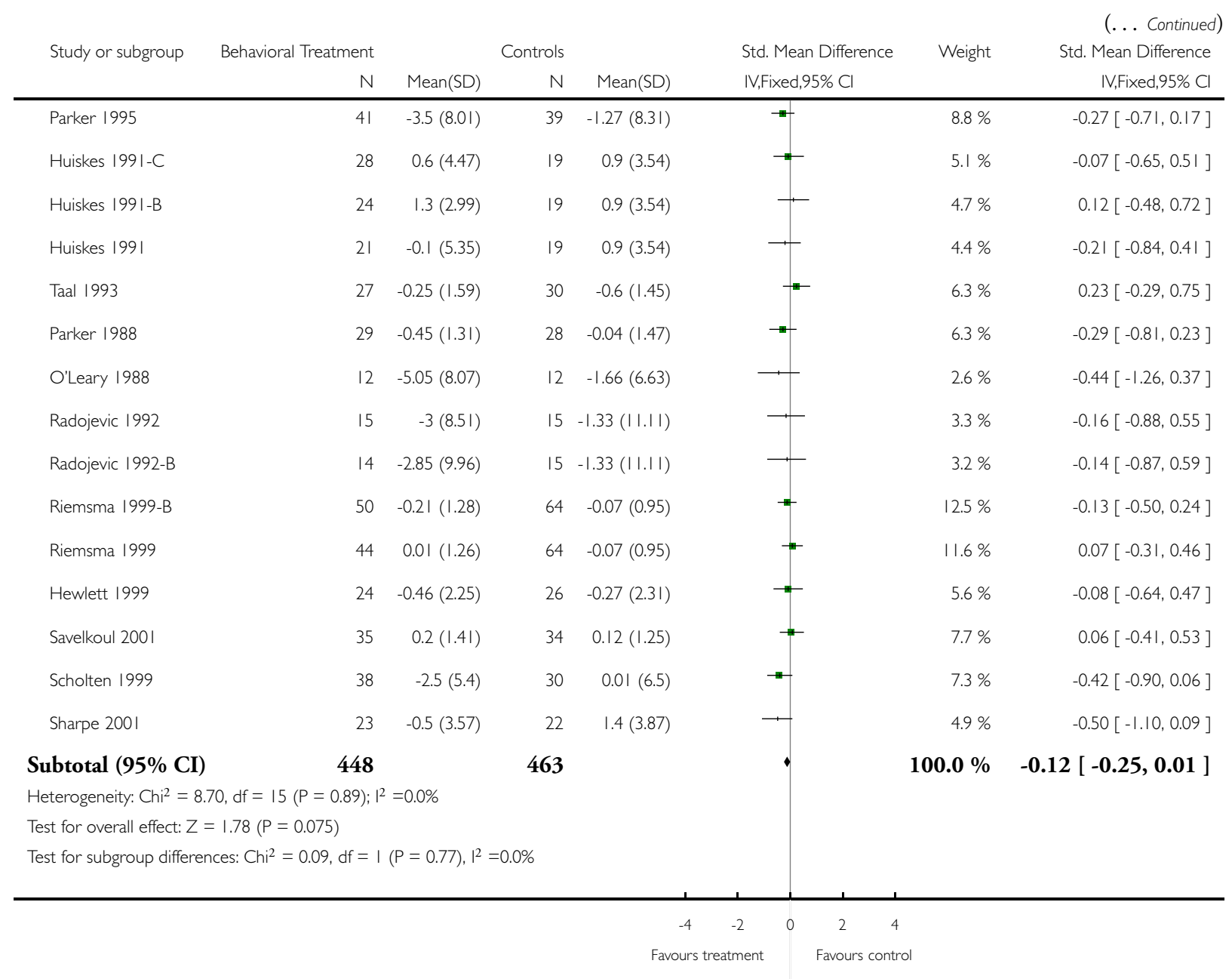


Analysis 4.9. Comparison 4 Behavioural Treatment versus Controls, Outcome 9 Disease Activity.

Review: Patient education for adults with rheumatoid arthritis

Comparison: 4 Behavioural Treatment versus Controls

Outcome: 9 Disease Activity

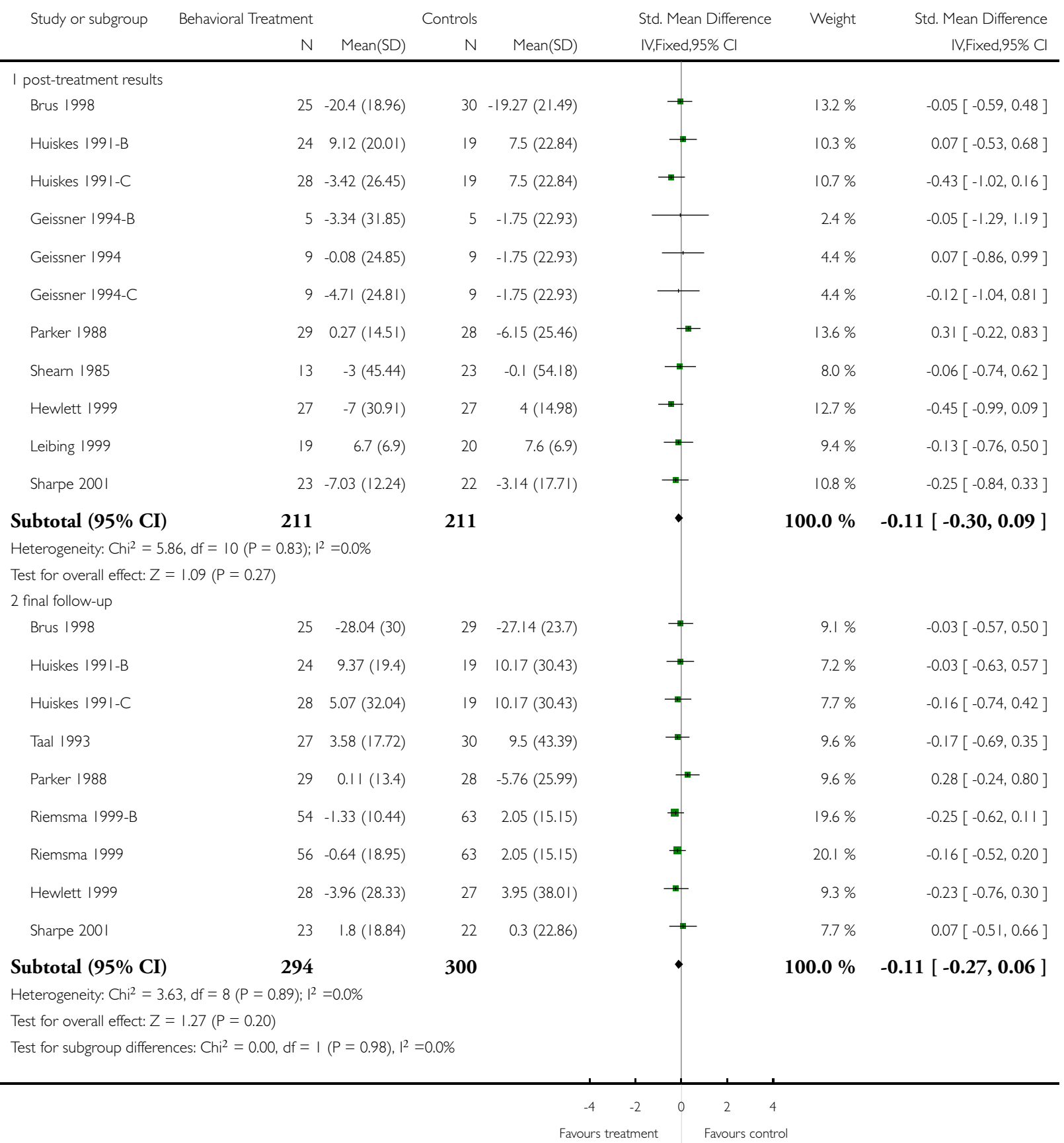

Patient education for adults with rheumatoid arthritis (Review) 


\section{A P P E N D I CES}

\section{Appendix I. EMBSE and PsycINFO search strategy}

1 clinical trial?.tw

2 study.tw

3 evaluation.tw

4 program.tw

5 experiment.tw

61 or 2 or 3 or 4 or 5

7 rheumatoid arthritis.tw

8 arthritis.tw

97 or 8

10 health promotion.tw

11 patient education.tw

12 behavior therapy.tw

13 occupational therapy.tw

14 self care.tw

15 psychological adaption.tw

16 counseling.tw

17 exercise therapy.tw

1810 or 11 or 12 or 13 or 14 or 15 or 16 or 17

196 and 9 and 18

tw = text word; ? = wild card

\section{WHAT'S NEW}

Last assessed as up-to-date: 20 February 2003.

\section{November 2008 Amended Converted to new review format.} CMSG ID: C063-R

\section{H I S T O R Y}

Protocol first published: Issue 1, 1999

Review first published: Issue 2, 2002 


\section{CONTRIBUTIONS OF AUTHORS}

Rob Riemsma: Lead reviewer responsible for writing the scope of the review, protocol and final review; involved in the selection of studies, and the extraction and synthesis of data.

Erik Taal: Involved in producing the scope of the review and protocol; read and commented on the final draft report. Assisted in the selection of studies.

John Kirwan: Involved in producing the scope of the review and protocol; read and commented on the final draft report. Assisted with the development of the quality checklist, and quality assessment.

Hans Rasker: Involved in producing the scope of the review and protocol; read and commented on the final draft report.

\section{DECLARATIONS OF INTEREST}

The first (RR), third (ET) and fourth (JR) author participated in two of the included studies (Riemsma 1999; Taal 1993), the third and fourth author participated in another study included (Brus 1998), and the second (JK) author participated in one study (Hewlett 1999).

\section{SOURCES OFSUPPORT}

\section{Internal sources}

- NHS-Centre for Reviews and Dissemination, University of York, UK.

- University of Twente, Netherlands.

- Bristol University, UK.

\section{External sources}

- No sources of support supplied

\section{NDEX TERMS}

\section{Medical Subject Headings (MeSH)}

*Arthritis, Rheumatoid [drug therapy; psychology]; * Patient Education as Topic; Anti-Inflammatory Agents, Non-Steroidal [therapeutic use]; Randomized Controlled Trials as Topic

\section{MeSH check words}

Humans 